University of Louisville

ThinkIR: The University of Louisville's Institutional Repository

Electronic Theses and Dissertations

8-2013

\title{
The four others in I. Kadare's works : a study of the Albanian national identity.
}

Jing Ke

University of Louisville

Follow this and additional works at: https://ir.library.louisville.edu/etd

\section{Recommended Citation}

Ke, Jing, "The four others in I. Kadare's works : a study of the Albanian national identity." (2013). Electronic Theses and Dissertations. Paper 730.

https://doi.org/10.18297/etd/730

This Doctoral Dissertation is brought to you for free and open access by ThinkIR: The University of Louisville's Institutional Repository. It has been accepted for inclusion in Electronic Theses and Dissertations by an authorized administrator of ThinkIR: The University of Louisville's Institutional Repository. This title appears here courtesy of the author, who has retained all other copyrights. For more information, please contact thinkir@louisville.edu. 
THE FOUR OTHERS IN I. KADARE'S WORKS

- A STUDY OF THE ALBANIAN NATIONAL IDENTITY

by

KE Jing

B. A., Prishtina University, Kosovo, 1989

M. A., Beijing Foreign Studies University, China, 2003

\author{
A Dissertation \\ Submitted to the Faculty of the \\ in Partial Fulfillment of the Requirements \\ for the Degree of \\ Doctor of Philosophy \\ Department of Humanities \\ University of Louisville \\ Louisville, Kentucky
}

College of Arts and Sciences of the University of Louisville

August 2013 
Copyright ( 2013 by KE Jing

All Rights Reserved 

THE FOUR OTHERS IN I. KADARE'S WORKS

- A STUDY OF THE ALBANIAN NATIONAL IDENTITY

by

KE Jing

B. A., Prishtina University, Kosovo, 1989

M. A., Beijing Foreign Studies University, China, 2003

A Dissertation Approved on

August 5, 2012

By the following Dissertation Committee

Prof. Dr. Mark Blum (Director)

Prof. Dr. Annette Allen

Prof. Dr. Charles Ziegler

Prof. Dr. Svetlana Stoicheva 


\section{ACKNOWLEDGEMENTS}

I would like to express my sincere gratitude to all those who have helped me in my pursuit of a Ph.D. in humanities.

First of all, I would like to thank my dissertation director Prof. Mark Blum who has guided me all the way through my writing process. I am profoundly grateful to Prof. Blum for his trust and encouragement. His insightful suggestions and constructive criticism broadened my academic vision and deepened my understanding of Kadare as a writer.

I also feel grateful to the other three professors on my dissertation committee, Prof. Annette Allen (Director of the UoL-BFSU Ph.D. Program), Prof. Charles Ziegler (Director of Political Science at UofL) and Prof. Svetlana Stoicheva Anderson (Professor of Slavic Languages and Literatures at Sofia University), for their valuable comments, kind support and warm encouragement.

I feel extremely lucky that I had the opportunity to become part of the joint $\mathrm{Ph}$. D. Program between the University of Louisville (UofL) and Beijing Foreign Studies University (BFSU), from which I have benefited tremendously. The professors who taught me knowledge and research methodology brought me into the wonderful world of humanities. I owe my sincere gratitude to Prof. Annette Allen, Prof. Osborne Wiggins, Prof. Elaine Wise, Prof. Robert St. Clair, Dr. Pamela Beattie from UofL and Prof. Jin Li, Prof. Sun Youzhong, Prof. Zhang Jian, Prof. Wu Yi'an, Prof. Zhang Zaixin, Prof. Chen Guohua and Prof. Chen Dezhang from BFSU. Their expertise and commitment made my doctoral studies an unforgettable and rewarding experience. 
My special thanks also go to Dr. Sun Xiujie, the coordinator of the Program, for her full support and indispensable help.

I would like to express my appreciation to my friend Allan Ross and Ashly Bender of the Virtual Writing Center of UofL for proof reading the dissertation and giving advice on proper writing, and to Ms. Courtney Kerr of the Graduate School of UofL for her professional help with the dissertation formatting.

My heartfelt thanks are also due to my dear colleagues: Prof. Ding Chao (Former Dean of the School of European Languages and Cultures, BFSU), Prof. Zhao Gang (Present Dean of the SELC, BFSU), Prof. Chen Ying (Vice-dean of the SELC, BFSU), Ms. Chen Fenghua (Head of the Albanian program at BFSU), Ms. Jin Qiao (Lecturer of Albanian language) and Mr. Ruzhdi Stringa (visiting professor from Albania). Their genuine friendship and unconditional support have contributed greatly to the completion of my dissertation.

I am deeply indebted to my Albanian professors and friends who have frankly shared with me their understanding of Kadare and his works. They are: Prof. Rexhep Qosja, Prof. Rexhep Ismajli, Prof. Emil Lafe, Prof. Shaban Sinani, Prof. Mark Marku, Prof. Shezai Rrokaj, Mr. Lulëzim Shishani, Ms. Edlira Late, Prof. Bizena Bijo, etc. No matter how much they agree or disagree with my interpretations of Kadare's works, they have shown their friendliness and dignity. Their academic openness, their absolute sincerity and their true love for the nation make me feel pround and honored that I am a teacher and researcher of Albanian language and culture. My gratitude also goes to Mr. Maxhun Peka (Former Albanian Ambassador to China) and Mr. Kujtim Xhani (Present Albanian Ambassador to China) who gave substantial support to me and the Albanian Program at BFSU over the past years.

Finally, I want to thank my family for their continuing love, understanding and 
support throughout my entire doctoral studies. Without their selfless love and support, I would not have been able to complete this dissertation.

To all of them I feel immensely grateful from the bottom of my heart. 


\title{
ABSTRACT \\ THE FOUR OTHERS IN I. KADARE'S WORKS \\ - A STUDY OF THE ALBANIAN NATIONAL IDENTITY
}

\author{
by
}

KE Jing

August 5, 2013

Nationalism, as one of the most powerful forms of social mobilization in the contemporary world, was utilized as an effective ideological tool by Hoxha's communist regime to construct the Albanian national identity. As an essential part of the process, the 'Other' was employed to strengthen the nation's self-image and to justify the regime's foreign policies and internal campaigns.

Ismail Kadare, the most prominent Albanian writer to serve the national-communist ideology, has become a controversial figure since the collapse of Albanian Communism in the early 1990s. Scholars differ in their opinions of Kadare's role under the Albanian communist regime and his current claim that the Albanian national identity is purely European.

Based on the observation that Othering is Kadare's most preferred means of treating national and personal identity issues, this dissertation examines all aspects of Otherness created by Kadare through the rhetoric of exclusion in service of the Albanian national identity formation. While acknowledging Kadare's value as a great writer, the study focuses on Kadare's role in the Albanian national identity construction, his opportunistic failings and the limitations of his Self-Other 
dichotomist mentality. It proves that Kadare is a superb master of employing myths and historiography to create the paradigm for the Albanian people to forge their unique national identity.

By examining the four Albanian national Others presented in Kadare's works, namely the Western, Oriental, Internal and Neighboring Others, the historical backgrounds for the appearance of the four Others, and the present rhetoric of calling the Western Other 'Mother', the dissertation illustrates the political nature of national identity, the fluidity of the political identity of the nations situated in the gray zone between East and West, and the relationship between literature and politics.

This research demonstrates that Kadare's life as a writer and his life as a person "are maintained on two parallel rails". As a balance to the criticism of Kadare's dichotomist mentality in treating his personal and the Albanian national identities, the non-dichotomist side of Kadare and his humanistic vision as reflected in his literary fictions is examined in the final chapter. The dissertation concludes by calling for efforts from intellectuals like Kadare to build humanistic platforms on which nations can be oriented to go beyond the limitations of political Othering. 


\section{TABLE OF CONTENTS}

CHAPTER 1 WHY KADARE?

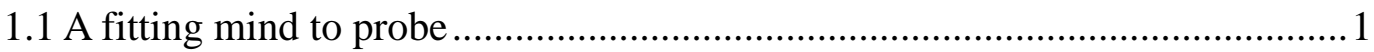

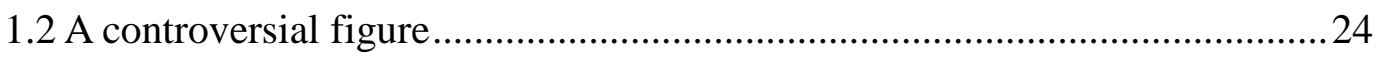

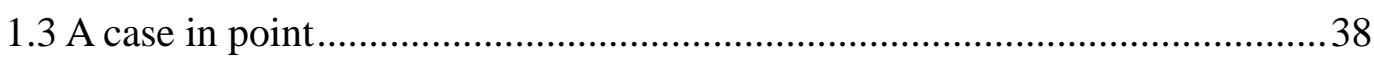

CHAPTER 2 THE WESTERN OTHER .............................................................49

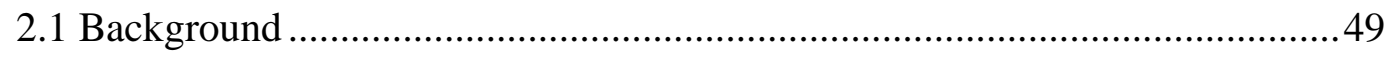

2.2 The Hostile Other.................................................................................... 53

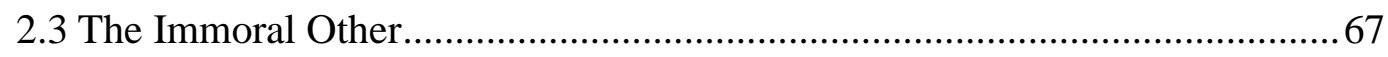

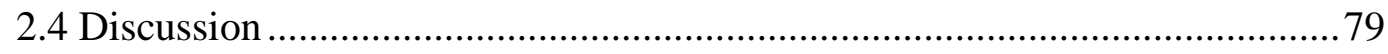

CHAPTER 3 THE ORIENTAL OTHER ......................................................84

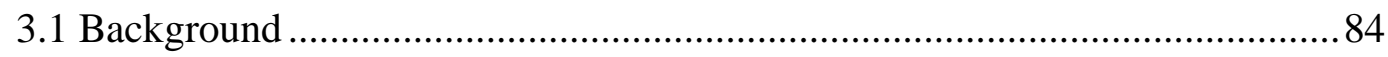

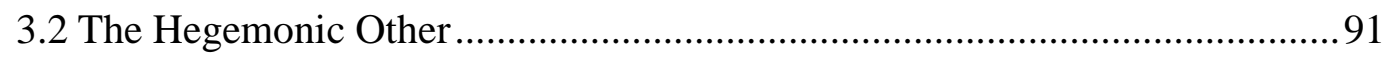

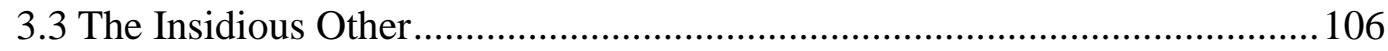

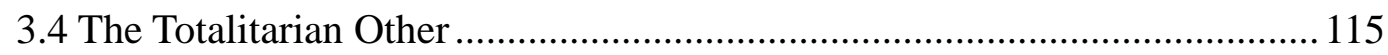

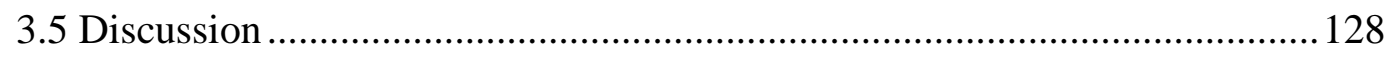

CHAPTER 4 THE INTERNAL OTHER ........................................................136

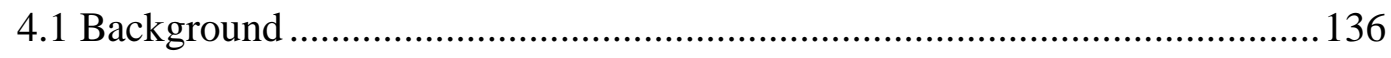

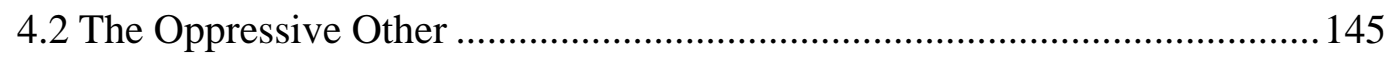




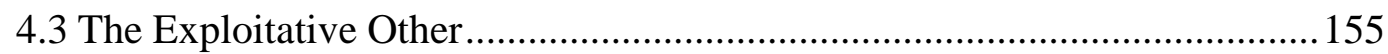

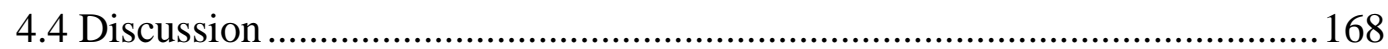

CHAPTER 5 THE NEIGHBORING OTHER.................................................177

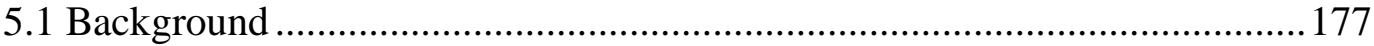

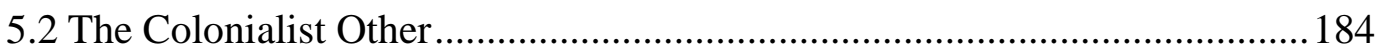

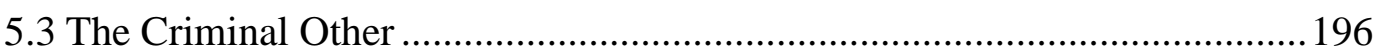

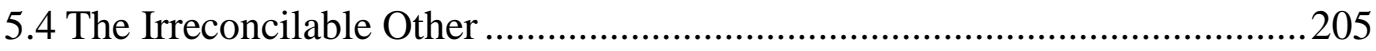

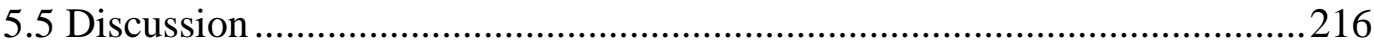

CHAPTER 6 FROM OTHER TO MOTHER ......................................................226

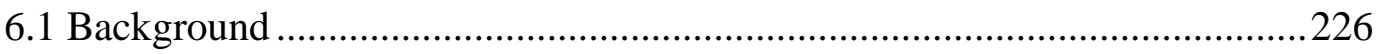

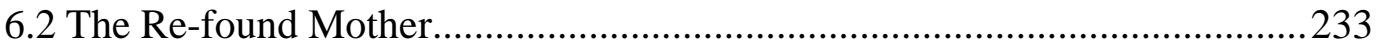

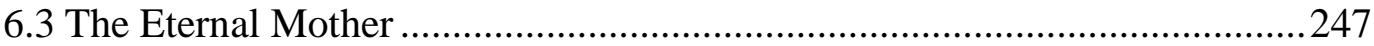

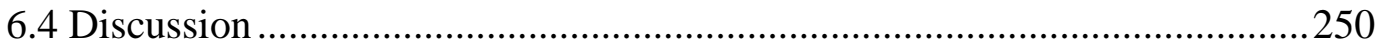

CHAPTER 7 TRANSCENDING THE OTHERNESS...................................258

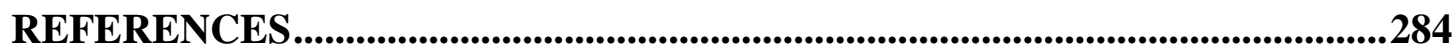

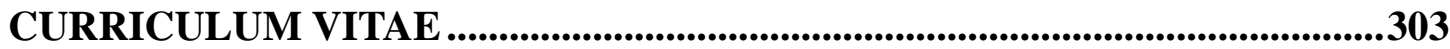




\section{CHAPTER 1 WHY KADARE?}

\subsection{A fitting mind to probe}

Ismail Kadare is a writer who maps a whole culture - its history, its passion, its folklore, its politics and its disasters.

-- John Carey, chairman of the judging committee of Man Booker International (MBI) Prize 2005

I am a writer from the Balkan fringe, a part of Europe which has long been notorious exclusively for news of human wickedness. My firm hope is that European and world opinion may henceforth realize that this region, to which my country Albania belongs, can also give rise to other kinds of news and be the home of other kinds of achievement.

-- Ismail Kadare, after winning 2005 MBI Prize ${ }^{1}$

In 2005, the Albanian writer Ismail Kadare became the winner of the inaugural prize of Man Booker International, beating all the other well-known contenders such as Gabriel Garcia Marquez, Milan Kundera, etc. The above quotes show, on the one hand, that Kadare has been highly acknowledged internationally, especially for his merit of combining the history, folklore and politics of his nation in literary works; and on the other hand, they also demonstrate Kadare's concern about the image of the Balkans, a place described by him as "notorious exclusively for ... human wickedness," where Albania constitutes an important part.

Indeed, in order to fit into the post-Cold War political circumstances

\footnotetext{
${ }^{1}$ Henley Jon and Kirsty Scott, "Albanian beats literary titans to first international Booker prize," The Guardian, June 3, 2005, http://www.guardian.co.uk/uk/2005/jun/03/world.books, accessed on Dec. 16, 2008. 
and gain a better image for his nation, Kadare has actively engaged himself in reconstructing the Albanian national identity. However, having been the key intellectual figure during the Albanian communist regime, Kadare must, at least partly, deconstruct the Albanian national identity constructed in his earlier literary works. In other words, Kadare's post-1990 efforts in reconstructing the Albanian national identity would be, to some extent, contradictory to what he wrote under Enver Hoxha's rule (1946-1985). The Others portrayed by Kadare for the formation of Albania's self-image and his post-1990 attempts to portray Albanian nation's identity as purely European make him the right mind to probe for a deep insight to the evolution of the Albanian national identity over the past six decades. Talking about the relationship between intellectuals and politics, Jameson points out, "In the third world literature, the intellectual is always in one way or another a political intellectual" (74). ${ }^{1}$ Kadare is no doubt a political writer whose literary creation has been politically oriented.

Kadare was born into a civil service employee's family in 1936 in Gjirokastra, a southern Albanian city near Greece. His family lived in the same neighborhood with the former Albanian communist leader Enver Hoxha. During World War II, Gjirokastra was a contested battleground between Italians/Germans and Greeks. In addition to foreign occupations, Gjirokastra also witnessed severe fighting between the Balli Kombëtar ${ }^{2}$ nationalists and the Albanian communist partisans. Therefore, Kadare saw in his childhood the cruelty of war and experienced the wartime social turbulence. In 1946, before Kadare reached the age of ten, the Albanian Communist

\footnotetext{
${ }^{1}$ Fredric Jameson, "Third-World Literature in the Era of Multinational Capitalism," Social Text 15.1-2, 1986: 65-88.

2 Balli Kombëtar literally means National Front. It was the Albanian nationalist, anti-communist and anti-monarchist organization during the Second World War (established in November 1942). After WWII, Balli Kombëtar was defeated by the Albanian Communist Party. Balli fighters fled to Austria, the US, Australia, Switzerland etc. They were the forces used between 1949 and 1954 by the West as commandos to overthrow Enver Hoxha's regime.
} 
Party seized power and established the People's Republic of Albania. From then on, Kadare started to receive school education and the indoctrination of the communist ideology.

Kadare did his primary and secondary schools in his hometown, after which he went to the University of Tirana and majored in literature. In 1958, he was selected to attend the Gorky Institute of World Literature. In 1960, his studies in Moscow were interrupted by the deterioration of relations between Albania and the Soviet Union. Upon returning to Albania, Kadare became a journalist. In 1963, he married Helena Gushi, the first woman in Albanian history to publish short stories and novels. ${ }^{1}$ Talking about his time in Russia, Kadare said, "I knew of Stalin's crimes, the disillusionment of the Russian with communism, their despair and boredom". 2 Although Kadare stayed only two years in Russia, this study-abroad experience was important for him to catch the essence of literature and the relationship between literature and politics. He observed from nearby the Pasternak incident ${ }^{3}$ and came to understand the role of writers and their potential dangers in literary creation.

Kadare began his literary career as a poet. His first verse collections Frymëzimet djaloshare (Youthful Inspiration, 1954) and Ëndërrimet (Dreams, 1957) are full of youthful inspirations. In early 1960s, Kadare published Shekulli im (My Century, 1961) and Përse mendohen këto male (What Do These Mountains Think About, 1963), where he expressed his enthusiasm and belief in building a paradise-like Albania under the leadership of the Party. ${ }^{4}$ The latter poem portrays the Party as the savior of

\footnotetext{
${ }^{1}$ Elena Gushi Kadare was born in 1943 in Fier, Albania. The novels she has published include Një lindje e vështirë (A difficult birth, 1970), Një grua nga Tirana (A woman from Tirana, 1990), Bashkëshortët (Spouses, 2002), Kohë e pamjaftueshme (Insufficient time, 2011).

${ }^{2}$ Ismail Kadare: Albanian Spring: the Anatomy of Tyranny, trans.Emile Capouya (London: Saqi, 1995) 154.

${ }^{3}$ Boris Pasternak was awarded the Nobel Prize for Literature in 1958. He first accepted the award, but then, under intense pressure of the Soviet authorities, he declined it. He died in 1960.

4 "The Party" refers to the ruling Party in Albania before the 1992, i.e. the Albanian Communist Party (founded in 1941) and the Albanian Labor Party (the former Albanian Communist Party renamed in 1948, after Albania's split with Yugoslavia).
} 
the Albanian people. The mountains were personified and empowered the ability to think. They recalled the sufferings and heroisms in Albanian nation's history and eventually came to realize that only the Party was able to lead the people out of darkness and avoid the evils of the Western capitalist world. For this poem, Kadare received a congratulatory telephone call from E. Hoxha and became a favorite poet of the Party. ${ }^{1}$ These early poems demonstrate young Kadare's passion to communism and his trust in the Party.

However, it was Kadare's prose that gained him fame in literature. Kadare started to write prose in late 1950s. His first novel, Qyteti pa reklama (The Town without Signs) appeared in 1959 without much ado. But he didn't wait long to become a famous novelist. His second novel, Gjenerali i ushtrisë së vdekur (The General of the Dead Army, 1963) was a great success. The story tells of an Italian general who came to Albania accompanied by an Italian priest with the mission to exhume and repatriate the remains of the fallen officers and soldiers during WWII. The task took them a whole year. Through the general's dramatic psychological change from initially proud of his mission to finally frustrated and depressed, Kadare spelled out, on the one hand, the doomed destiny of foreign invaders and the moral dismantling of the haughty West, and on the other hand, the Albanian people's humanitarian spirit, their hospitality and their determination to defend their country. Different from a traditional war narrative, the novel reflects the psychological trauma of war inflicted on both of the peoples involved. This is Kadare's first successful experiment of using the indirect Aesopian language to convey political messages. The novel was translated into French in 1971 and then into many other languages, making Kadare a writer with

\footnotetext{
${ }^{1}$ Razi Brahimi, "Kadare ishte si 'monument kulture', e mbronin Enveri dhe Ramiz Alia," (Kadare was like a 'cultural monument' protected by Enver and Ramiz Alia) interview, Panorama, April 29, 2012. Accessable on http://www.panorama.com.al/2012/04/29/razi-brahimi-kadare-ishte-si-\%E2\%80\%9Cmonument-kulture\%E2\%80\% 9D-e-mbronin-enveri-dhe-ramiz-alia/
} 
international fame.

After The General of the Dead Army, Kadare turned increasingly to prose writing. In 1965, he published a short novel titled Përbindëshi (The Monster), where he tried to re-model the siege of Troj into a modern story while using the technique of compositional disorder and subjective use of time. ${ }^{1}$ The novel was criticized as a “decadent" work and banned for republication till $1991 .^{2}$ In Kadare's own words, it "was flogged, forbidden and buried so deeply that it would take me over a quarter of a century to exhume it". ${ }^{3}$

To be on the safe side, Kadare turned to socialist realism and took up the theme of women's emancipation. He wrote a novel to echo Hoxha's call to fight against reactionary survivals, particularly the patriarchal and religious oppression. Kadare originally titled the novel as Lëkura e daulles (Skin of the Drum), but it was published under the title Dasma (The Wedding, 1968). ${ }^{4}$ In the latest complete collection of his works, Kadare put the novel back under the original name. Actually many of Kadare's works have been re-titled or re-written. As pointed out by David Bellos ${ }^{5}$, Kadare is an "obsessive rewriter of himself" (vii). ${ }^{6}$

The novel revolves around the conflict between the deeply ingrained backward tradition and the progress of socialist modernization. In 1969, it was adapted into a

\footnotetext{
1 Prof. Shaban Sinan wrote the entry for "Ismail Kadare" in The Albanian Encyclopedic Dictionary (to be published soon, the entry was kindly sent to me for reference), where he explained the reasons why The Monster was prohibited. The same information can be found at http://www.akad.edu.al/KADARE\%20Ismail, accessed on Jan. 15, 2009.

${ }^{2}$ Eric Faye, Preface to Përbindëshi, in Kadare's Vepra, vol. 1, Tirana: Onufri, 2007, pp. 229-396.

3 Ismail Kadare, Pesha e kryqit (The Weight of the Cross), Paris: Fayard, 1991, p.27.

${ }^{4}$ The novel was translated into English by the Albanian scholar Ali Cungu and published in the same year in Tirana under the title The Wedding.

${ }^{5}$ David Bellos is the winner of the translator's Prize of the Man Booker International 2005. He translated many of Kadare's works, including The File on H., Chronicle in Stone, Agamemnon's Daughter, The Pyramid, The Successor, The Siege, etc. But there is no lack of criticism, as the translation is done from the French versions instead of from Albanian. For example, the Albanian writer Blendi Kraja said in a letter (January 15, 2006) to Bellos: "To translate from a second language is like washing your clothes in the same waters where someone else has washed his own beforehand." (Quoted from Barry Baldwin's article "Call me Ismail, Kadare's Capers" published at Ready Steady Book for Literature, http://www.readysteadybook.com/Article.aspx?page=onkadare)

David Bellos, "Introduction" to Ismail Kadare's Chronicle in Stone, Trans. Arshi Pipa, Ed. David Bellos. Edinburgh, New York, Melbourne: Canongate, 2007.
} 
movie to better serve the cause of emancipating women from patriarchal oppression and eliminating illiteracy. In order to showcase to the West the social progress in the socialist Albania, it was translated into English, Norwegian, Swedish, Dutch and Spanish. Though nowadays viewed as of limited artistic value or even an artistic failure, The Wedding remains an important literary work that reflects the construction of Albanian national identity during Hoxha's rule.

Kadare wrote about the Albanian National Liberation. But unlike those who treated this theme by depicting explicitly the heroism of the communist partisans, Kadare reflected it in an innovative way. In 1971, Kadare published Kronikë në gur (Chronicle in Stone), one of his most famous works. ${ }^{1}$ The novel depicts, from a child's perspective, the life of Albanians in the city of Gjirokastra during WWII and their reactions to foreign invasions. Throughout the book, Kadare gives a rather gloomy and bizarre picture of his hometown. By displaying the social backwardness, ignorance, superstition and poor national consciousness of the people before the establishment of the People's Republic of Albania, the novel can be viewed as a mirror reflecting the rapid social progress and the enhancement of Albanian people's national consciousness during 1950s and 1960s under Hoxha's leadership. Due to the child's bizarre imagination and magical view of life, the novel has been compared with that of Gabriel Garcia Marquez and commented as a work of magic realism.

Kadare is particularly good at writing historical novels to treat the political themes of his time. Kështjella (The Castle, 1970), ${ }^{2}$ for example, tells about Albania’s

\footnotetext{
${ }^{1}$ Before it appeared in the form of a novel, the work was first published in 1964 in the literary periodical Nëntori (November) under the title "Qyteti i Jugut" ("The Southern City"), and in 1967 in the collection of short stories named Qyteti i Jugut, tregime dhe reportazhe (The Southern City: Short Stories and Reportages). Its first English translation was published in 1987.

2 The novel was once titled Daullet e shiut (Drum of the Rain). The English translation was done by Pavli Qesku directly from Albanian and published in 1974. In 2008, the novel was included into the third volume of the complete collection of Kadare's works under the title Rrethimi (The Siege). In the same year, the English translation under the title The Siege was published, a re-translation by David Bellos from Jusuf Vrioni's French translation, but with remarkable changes from the previous versions.
} 
heroism in the $15^{\text {th }}$ century resistance war led by Skanderbeg (1405-68) against the mighty Ottoman Empire's expedition, but it actually serves to applaud Hoxha's policy against the hegemonic USA and USSR. Therefore the novel was considered by the Albanian communist authorities as highly positive for strengthening the people's patriotism and their readiness to fight against any possible foreign invaders. As a result, the novel became a great success in Albania and was officially translated into a dozen languages, including French, English, Dutch, Portuguese, Serbo-Croatian, Greek, Italian, Hungarian, Spanish, German, etc.

In early 1970s, Enver Hoxha became highly alert toward the increasing attempts of the Albanian intellectuals to liberate the Albanian arts and literature from rigid restrictions. He saw these attempts as signals of Westernization and threats to his rule in Albania. On the $4^{\text {th }}$ Plenary Session of the Central Committee in 1973 , Hoxha launched a campaign against the liberal forces, calling on the people to fight against the intrusion of corrupted Western culture. The liberal movement was swiftly crushed and its two leading heads were liquidated. Trusted and appreciated by Enver Hoxha, Kadare survived this campaign. As a collaborative gesture, Kadare produced during the 1970s some works which, in his own words, were written to ensure his survival. ${ }^{1}$ From 1970 until 1982, Kadare served as a deputy in the Albanian parliament. He was one of the very few writers who were privileged to travel and publish abroad.

Nëntori i një kryeqyteti (November of a Capital City, 1974) and Dimri i madh (The Great Winter, 1973) are two of Kadare's works of this period to safeguard his

\footnotetext{
${ }^{1}$ For the Albanian writers, the years following 1973 were a hard time. Those who were found to be tainted with liberalism were severely punished. Almost all major authors had a work withdrawn from circulation. According to Kadare himself, he was also criticized for his poem "the Red Pashas" (1975), which depicted the Central Committee members as taking the cloaks of the executed enemies and putting them on their own shoulders, and as a result was banned from publication for three years. But Noel Malcolm was doubtful about this story, arguing that Kadare is not the type that would commit self-destruction by confronting the entire Communist hierarchy, and what's more, that the text of the poem has never been printed. N. Malcolm also questioned the truth of Kadare being banned from publication for three years because of the poem, pointing out that four of Kadare's books were published in 1976-1977. See Noel Malcolm's "In the Palace of Nightmares." Review of The Three-Arched Bridge, by Ismail Kadare. New York Review of Books 44.7 (6 Nov. 1997): 21-24.
} 
position. November of a Capital City glorifies the partisans' fight in Tirana toward the end of WWII when the German forces were retreating. One important chapter was dedicated to the wisdom of Enver Hoxha. ${ }^{1}$ The novel focuses on a partisan squad whose task was to take over the radio station in Tirana. By reflecting the cut-throat ideological fight between the partisans and the bourgeois intellectuals before the founding of the new communist Albania, it served to legitimate the crackdown of the voices for liberalism that emerged in early 1970s.

The Great Winter is a lengthy novel about Albania's break with the Soviet Union. The novel was written in 1971 and first published in 1973 under the title Dimri $i$ vetmisë së madhe (The Winter of Great Solitude). It was republished in 1977 after having been revised and renamed as The Great Winter. ${ }^{2}$ In 1961, Albania broke with the Soviet Union, denouncing it as "imperialist and revisionist". The major reason for Albania-Soviet rupture is that Hoxha felt seriously threatened by Khrushchev's anti-Stalinist reform. Kadare did not address this issue directly, though. Instead, he presented Khrushchev's arrogant attitude toward Albania and the Soviet Union's refusal to provide grain aid to Albania as the key issue. In the novel, Enver Hoxha is glorified as a defender of Albania's national interests and a daring communist fighter against the hegemonic revisionist superpower. According to Kadare's own explanation, this work was intended to win Enver Hoxha's protection.

In 1977, Kadare published a short novel titled Breznia e Hankonatëve (The Lineage of the Hankonis) to highlight the economic achievements in the socialist Albania. The novel traces the failures and successes of the Hankoni family over a period of two centuries, aiming to convey the message that only the Party can lead the

\footnotetext{
1 This whole chapter has now been deleted and other changes have been made for new editions.

2 The novel was put on screen in Albania in 1979 under the name Face to face (Ballë për ballë). In the latest collection of Kadare's works, the novel appears in volume V (all together 20 volumes) under the original title but not with the original text. The work has obviously been retouched, either for artistic or political reason. This novel has not been translated into English yet. The translation of the passages analyzed in this study is done by author of the dissertation.
} 
Albanian people to a happy and decent life. This novel was not as successful as expected. What strengthened Kadare's position as the best Albanian writer was his three short novels in late 1970s: Ura me tri harqe (The Three-Arched Bridge, written 1976-1978, published for the first time in 1978) ${ }^{1}$, Prilli $i$ thyer (Broken April, written in 1978, published in 1980) ${ }^{2}$ and Kush e solli Doruntinën? (Who Brought Doruntine Back?, known as Doruntine, written in 1979 and published in 1980). ${ }^{3}$

The Three-Arched Bridge is based on Albania's history in the $14^{\text {th }}$ century and the folkloric legend of Rozafa. The legend is about the building of the Albanian northern city Shkodra. Three brothers worked all day but the walls kept falling down at night. An old man told them that for the castle to stand there must be a human sacrifice. The brothers were all married; none of them volunteered to sacrifice his wife. Finally they agreed to sacrifice the one who would bring them lunch the next day. The two elder brothers broke their promise and told their wives about the secret agreement. When Rozafa, the wife of the youngest brother, showed up the next day with lunch, she was told that they had to immure her into the wall. She calmly accepted her fate but asked to leave her right breast exposed to feed her infant son, her right eye to see him, her right hand to caress him and her right foot to rock his cradle. Nowadays people can still see something like milk flowing from one of the walls of the Rozafa Castle in Shkodra. This beautiful tragic story is only one version of the immurement legends in the Balkans. Similar legends also exist in Greece, Serbia etc. and they have served as sources for contemporary literary creation. The best example is the Serbian writer Ivo Andrić's novel Na Drini ćuprija (Bridge on the Drina, 1959), for which he won the

\footnotetext{
${ }^{1}$ It is translated into English as The Three-Arched Bridge, trans. John Hodgson, New York: Vintage International, 1997.

${ }^{2}$ Broken April was translated into English by multiple authors from Albanian and first published by Saqi Books, London, in 1990. The Brazilian director Walter Salles was so moved by the novel that he turned it into a movie named Behind the Sun, for which he won the Little Golden Lion award in 2002.

3 The English version appeared under the title Doruntine, trans. Jon Rothschild, New York: New Amsterdam, 1988.
} 
Nobel Prize. Inspired by Andrić's success, Kadare created a new immurement legend, where he treats the theme of Albania's fate in the filthy rivalry between West and East. Through the events surrounding the construction of a bridge across a strategically important river on Albanian territory, the novel depicts the political and economic competition and conflicts between the collapsing Byzantium and the rising Ottoman Empire. It is a masterpiece which epitomizes the neorealist theory that power is the most important factor in international relations. The novel is often viewed as Kadare's lament over Albania's ill fate of falling into the Ottoman Empire. But on the other hand, by exposing how the local princes lost their independence, it actually served to legitimate the Party's autarky policy.

Broken April, a story of blood feud set in the 1930s in northern Albanian mountains, is highly valued for the author's penetrating treatment of the classic theme of life and death. However, politically, by presenting the Albanian unwritten law of Kanun $^{1}$ and the feudal ruling class as the enemy of the people, i.e. the Internal Other of the Albanian nation, the novel served the purpose of consolidating Hoxha's absolute authority, particularly in northern Albania. Through the eyes of a newly-wedded couple from Tirana and the tragic fate of a young Albanian mountaineer, the novel uncovered the absurd and inhuman nature of Kanun. Meanwhile, by describing northern Albania and Kosovo as a whole region under the rule of Kanun, the novel is also a subtle claim of sovereignty over Kosovo, i.e. an implicit accusation of the neighboring Serbia as the colonialist Other of the Albanian nation.

Shortly afterwards, based on another Albanian legend, Kadare published a thriller titled Who Brought Doruntine Back?. According to the Albanian medieval legend,

\footnotetext{
${ }^{1}$ The Kanun is a set of traditional Albanian laws which stayed in the oral form before its publication in the 20th century.
} 
Doruntine married far away from home, and during her absence all of her eight brothers died in war or because of the war. Her mother felt extremely lonely and missed her day and night. Miraculously, Doruntine was brought home by her youngest brother Constantine, who had promised his mother when he was alive that he would bring his sister back whenever she would like to see her. The thriller revolved around the mystery of who brought back Doruntine. Did Constantine rise from the tomb and bring his sister back to his mother? In the course of sorting out the mystery, Captain Stress became aware of the political intrigue involved in the case. Using this legendary story, the author shows, on the one hand, the key component of the Albanian national identity Besa (the quality of keeping one's promise), and on the other hand, it exposes the Christian Church's evil attempt to maintain its firm grip on Albania. Enver Hoxha outlawed religion in 1967 and since then implemented an extremist anti-religion policy in Albania. The depiction of the Church as an evil Other of the Albanian nation makes the novel a conforming work to Hoxha's communist regime.

Like the Albanian intellectuals of the $19^{\text {th }}$ century National Renaissance, Kadare has been very concerned about the Albanian national issue, i.e. the establishment of a unified ethnic Albania, with Kosovo included. Howerver, constrained by Hoxha's diplomatic policy toward Yugoslavia before the 1980s, Kadare wrote almost nothing about Kosovo before 1980, except a short poem and some subtle implication in Broken April about Kosovo's sovereignty. In 1980s, Kadare started to take up the Kosovo issue in a series of his works, which signals the change of Hoxha's non-interference policy towards Kosovo. For fear of conflict with Josip Tito, Hoxha had dealt with Kosovo problem very cautiously. No provocative remarks were made before the 1980s by the Albanian side concerning Kosovo that could be interpreted as 
undermining Yugoslavia's sovereignty. In March 1981, ten months after Tito passed away, there were massive demonstrations demanding that Kosovo be given republic status. Kadare's novel Dosja $H$ (The File on H, 1981) ${ }^{1}$ appeared in such a political context. Identifying the old neighboring enemy as the hostile and evil "Other" of the Albanian nation, the novel marks an important change of Albania's policy toward Kosovo. Through the story of two Irish scholars' field research in the early 1930s on the links between the Homeric epic and the existing Albanian oral epic songs, Kadare attempts to make the point that Albanians are the Balkan autochthon population, whereas the Serbs are late comers. ${ }^{2}$ The main messages Kadare wants to convey are: first, the Albanians, the most ancient Balkan inhabitants, contributed to the origin of the Western civilization and provided the barbarian Slavs with an advanced culture, who turned out to be ungrateful, treacherous and deceptive; second, the itinerary of the bards of Albanian epic songs proves that Kosovo has been inhabited by the Albanians since the ancient time, far before the Slav intrusion. In this way, through Kadare's literary work, Albania put forward for the first time after WWII its historical claim to the Kosovo territory.

One important reason for Kadare popularity in Kosovo is that he wrote specific works where he expressed his solidarity with the Kosovo Albanians. After the Kosovo demonstrations in 1981 were suppressed by the Yugoslavian police, Kadare responded immediately with the short novel Krushqit janë të ngrirë (The Wedding Procession Turned to Ice, written between 1981-1983, published in 1986) to denounce the atrocity of the Serbian police and the anti-Albanian policy of the Serbian

\footnotetext{
1 The novel was translated into French in 1989, then into English by David Bellos from the French version. The first North American edition was published in 1998 by Arcade Publishing in New York.

2 The File on H. is based on the collection of epic songs by Albert Lord and Millman Parry back in 1930s in the Balkans. Lord and Parry concluded their research on Serbian-Croatian epic songs with the ground-breaking classic book The Singer of Tales, which explains two issues: the process which enables oral poets to improve poetry and the reason why orally improvised epics have their unique characteristics. However, when Kadare wrote The File on $\mathrm{H}$., he was more interested in conveying historical and political messages rather than discussing moral and poetic questions.
} 
government. ${ }^{1}$ According to Albanian mythology, the spirits of "ora", the forest fairies, would turn a wedding procession into ice if the wedding is not considered viable. This legend is used as an allegory to the situation in reality between Kosovo Albanians and Serbs. Through the experience of Teuta Shkreli, the surgery department director of a hospital in Prishtina, Kadare presents the political pressures, intrigues and intimidations imposed on the Kosovo Albanians. In addition, other figures such as Teuta's husband Martin Shkreli, one of the leading Albanian intellectuals in Kosovo, a few retired Serbian secret agents who dreamed of wiping out the Kosovo Albanians, Martin's student who was in love with a Serbian girl but killed in the demonstration by the Serbian police, etc. indicate that a harmonious coexistence between the Kosovo Albanians and the Serbs is impossible.

Kadare has been accused as a party hack due to his close relationship with Enver Hoxha and his works in service of the Albanian communist regime. However, if we look at Kadare's novel Nëpunësi i pallatit të ëndrrave (1981, now known in English as The Palace of Dreams), ${ }^{2}$ it would be hard to label him as a party hack. Some critics also refer to Kadare's another work written in mid-1970s, Pashallëqet e mëdha (The Great Pasha, 1978, known in French and German as The Niche of Shame), to argue against the accusation that Kadare was a conformist of the communist regime. For instance, Ahmet Selmani pointed out that "while reading the novel, it seems as if we are more in today's totalitarian time than in the time of the past" (Preface to Kamarja e Turpit 206). ${ }^{3}$

\footnotetext{
1 The novel was first published in Kadare's short story collection Koha e shkrimeve (The Time of Writings), Tirana 1986. It was translated into English by Robert Elsie and published under the title The Wedding Procession Turned to Ice in Robert Elsie, ed., Kosovo - in the Heart of the Powder Keg, pp. 105-192, 1997.

${ }^{2}$ Nëpunësi i pallatit të ëndrrave literally means The Official of the Palace of Dreams. It was later published under the Albanian title Pallati $i$ ëndrrave. Its English translation by Barbara Bray from the French version of the novel was published in 1993 by the Harvill Press in London.

3 Ahmet Selmani, Preface to Kamarja e Turpit, in Kadare Vepra 8 (Volume 8 of Kadare's Works), Tirana: Onufri, 2008, p. 206. The novel's original name is Pashallëqet e mëdha (The Great Pasha). In the latest collection of Kadare's works, it appears as Kamarja e turpit (The Niche of Shame, as it is called in French and German). The novel tells the story of how the rebellious Ali Pasha Tepelena (1740-1822) was beheaded and how his head was
} 
Kadare began to write The Palace of Dreams in 1976 and published the first two chapters in 1977 in the collection of short stories Emblema e dikurshme (The Emblem from the Past). The whole novel was published in 1981 in the second edition of The Emblem from the Past. It seems that even though Kadare was continuing to write in service of the Albanian communist regime, his inner world was suffering. This masterpiece is generally seen as a political allegory of totalitarianism and is often compared to Orwell's 1984. Meanwhile, in virtue of Kadare's impressive depiction of alienation, anxiety and absurdity, the novel is also compared to Kafka's works.

The protagonist, Mark-Alem, is a young man whose duty is to select, categorize and interpret dreams in order to warn the Sultan of potential threats to his rule. Being the scion of the Quprilis, a powerful family of ethnic Albanian origin in the Ottoman Empire, Mark-Alem experienced dramatic political adventures. The reader can easily perceive the protagonist's fear, dilemma and hopelessness in the totalitarian system. Kadare was criticized for political insinuation and as a result the republication of novel was banned. ${ }^{1}$

The Palace of Dreams indicates that Kadare started in the early 1980s to express his dissenting opinions. The novel can be interpreted as Kadare's inner struggle and his regret of losing himself under the communist totalitarian rule. As pointed out by the famous American critic Noel Malcolm, "The employee of the Palace of Dreams serves the Ottoman state, but retains in his heart another loyalty, ..., Ismail Kadare, likewise, had his own complex loyalties to an inner, mythic world, while never

brought to Istanbul to be placed in the niche of shame. It is considered to be one of Kadare's best works, but unfortunately there is no English translation of this novel. In the same volume is Kadare's another short story named Komisioni i Festës (The Celebration Commission), which treats the Manastir massacre in 1830, the same theme as in Kamarja e turpit, i,e. the brutal Ottoman suppression of the Albanian rebellious pashas.

${ }^{1}$ As a result, out of the 12 volumes of Kadare's works to be published in 1981, only 11 volumes came out. Volume 11, which was reserved for The Palace of Dreams, did not appear at all. Many factors should have contributed to Kadare's writing of The Palace of Dreams, including Kadare's sharp political observation, the decline of Enver Hoxha's health and power, the increasing attempts of the regime to control people's mind, the deterioration of Albania's self-isolated economy, the change of balance on the international political arena, etc. 
ceasing to be an employee of the Palace of Nightmare that was Enver Hoxha's Albania" (1997: 24). ${ }^{1}$

According to Kadare himself, he had always had "something deeper, something more timeless" which finally led to his decision to flee Albania in 1990. The first time he thought of running away from the intolerable Albanian dictatorship was in Prague in 1962, when he was returning from Finland. The second time was in 1983, when he was having serious problems after his quarrel with the regime throughout 1982 (1995: 60-62). ${ }^{2}$ Kadare's study in the Soviet Union, his privilege to visit France and other Western countries as well as his close observation of the totalitarian politics should have contributed his secret desire for freedom, democracy and well-being. Unable to leave Albania for various reasons, Kadare had to collaborate with the communist regime. His inner struggle explains to a great extent why his works in late 1970s and early 1980s are the most powerful and valuable masterpieces. Talking about his books written in the communist era, Kadare said: "Had I not turned again and again in my books to the theme of the man half alive, half dead? Had I not identified myself with that man? (60)"3 The close relationship Kadare maintained with Enver Hoxha and the constant rebellious voice from his inner mythic world resulted in the many alter ego Kadares he intentionally depicted in his works.

However, aside from the assertion that The Palace of Dreams reflects Kadare's psychological status in late 1970s and early 1980s, there are also other interpretations. Taking into consideration the emphasized theme of the awakening of the Albanian national consciousness in the collapsing Ottoman Empire, The Palace of Dreams can be seen as a novel conveying political messages to the Kosovo Albanian leaders that it

\footnotetext{
${ }^{1}$ Noel Malcolm, "In the Palace of Nightmares," Review of The Three-Arched Bridge, by Ismail Kadare. New York Review of Books 44.7 (6 Nov. 1997): 21-24.

${ }^{2}$ Ismail Kadare, Albanian Spring: the Anatomy of Tyranny, London: Saqi, 1995 (Reprint). Kadare explained in this work why he did not flee in 1983: when he raised the issue during his stay in Paris, his French friends told him that he ought to return to Albania.

${ }^{3}$ Ibid.
} 
was time for them to take the right political stand.

Around mid-1980s, Kadare published two other novels that further demonstrated his political inclination, Sjellësi i fatkeqësisë (The Bearer of Evil Tidings, 1984) ${ }^{1}$ and Viti $i$ mbrapshtë (The Dark Year, 1986). Kadare has always presented the Islam civilization as barbarian and harmful to the Albanian nation. But, before The Bearer of Evil Tidings he had never dealt so specifically with the theme of Islam dissemination. The novel is based on a fictitious order of the Sultan that all females of the Ottoman Empire be veiled. Hadji Milet, a caravan driver, is instructed to travel to the European part of the Ottoman Empire to deliver a half million veils for the non-Muslim women. What he saw and heard on his journey gradually changed his ethical understanding of his mission, which eventually led to his persecution and death. The message conveyed in the fiction is that Albanians originally belonged to the civilized Western culture, and that Islam culture was imposed upon them by the East.

The Dark Year has become better known in the recent years due to its adaptation into the film Koha e kometës (Time of Comet, 2008). The novel takes the reader back to the chaotic year of 1914 when the newly established Albania under the nominal rule of Western appointed Prince William of Wied was struggling for its survival in the very complicated context: the local Albanian warlords were fighting against each other, European great powers were attempting to intervene in the Balkan issues for their own interests, and the neighboring countries were eager to devour Albania. It is in essence a lamentation of the Albanian nation's dismemberment in 1913.

What is also worth noting in The Dark Year is that the main character Shestan

\footnotetext{
${ }^{1}$ The novel was first published in Albania's literary journal Nëntori in 1984. Its title has been translated into English by Elsie Robert as The Bearer of Evil Tidings in his paper "Evolution and Revolution in Modern Albanian Literature", World Literature Today, vol. 65, issue 2, 1991: 256-263, p. 260, and as The Bearer of Ill Tidings Islamo Nox in his book History of Albanian literature, New York: Columbia University Press, 1995, p. 554. The novel is available in French (1985, Paris) and German (1987, East Germany) but unfortunately not in English. It is translated as The Caravan of Veils by John Cox in his paper "What's Behind the Veil? The Ottoman Fiction of Ismail Kadare", Indiana Slavic Studies, Vol. 16, 2006.
} 
Verdha, captain of five villagers who decided to fight for their country, fell in love with a Catholic girl. Compared to The General of the Dead Army and Doruntine, where Western religion was depicted as something evil, the design of a Muslim man's love for a Catholic girl indicates Kadare's alteration in his view of the Albanian national identity. It can be interpreted as the prelude to Kadare's declaration in 1990:

I'm convinced that Albania will most likely embrace Christianity since it is linked to the country's culture, and to a nostalgic memory of the time before Turkish rule. In the coming years, Islam, which arrived late in Albania in the baggage of the Ottoman overlords, will weaken - first in Albania, and then in Kosovo. Christianity, or rather Christian culture, will hold its own throughout the country. (1995: 34) $)^{1}$

Apart from the Ottoman Empire and Islam civilization, the Soviet Union and China also appeared in Kadare's works as the Oriental "Other". As mentioned previously, the Soviet Other has been constructed by Kadare in quite a few works, either by analogy between the Soviet Union and the Ottoman Empire or by the direct treatment of the Soviet-Albanian rupture. China, after the Sino-Albanian friendship period between 1961-1978, became the Far East Oriental Other in Kadare's novel Koncert në fund të dimrit (1988, literally Concert at the End of Winter, known as The Concert). ${ }^{2}$ The Concert writes about the worsening of Sino-Albanian ties during the 1970s. The main characters in The Great Winter, the novel about the Soviet-Albanian breakup, reappear in The Concert. However, with a different purpose in the author's mind, The Concert stresses the depersonalization of individuals under the totalitarian surveillance. It is featured with an obvious anti-communist hue and a tone of celebration of Albania's final departure from the Far Eastern Empire. Mao Zedong's megalomaniac thoughts, the power-struggle between Mao Zedong and Lin Biao

\footnotetext{
${ }^{1}$ Ismail Kadare, Albanian Spring: the Anatomy of Tyranny (Nga një dhjetor në tjetrin), London: Saqi, 1995.

2 The novel was translated into English by Barbara Bray from the French version (1989) and published under the title The Concert by Arcade Publishing in New York, 1994.
} 
(Mao's designated successor), the artificial creation of Lei Feng as the national hero, the lack of personal freedom, the distortion of human nature under high pressure, and the naivety of the brain-washed people are all designed to denounce Chinese dictatorship. Due to its subversive satire of Communism, the book was well received by the West and was chosen as the best novel of the year 1991 by the French literary magazine Lire.

Kadare smuggled in 1986 some of his manuscripts to France, two of which were written around mid-1980s but published after Kadare exiled to France: Hija (The Shadow, 1994) ${ }^{1}$ and Vajza e Agamemnonit (Agamemnon's Daughter, 2003). ${ }^{2}$ These works are regarded by Kadare as evidence to prove that he wrote against communism long before its fall in Albania. Unlike The Palace of Dreams, these novels are more direct and open in attacking Hoxha's totalitarian regime. The Shadow can be viewed as Kadare's extended autobiography, a voyage from the Stalinist Albania to free Europe. The protagonist of the novel, an Albanian movie director, went to Paris for cultural exchanges, where he fell in love with an actress. He felt that going back to his country is like returning to hell. But meanwhile, he was aware that it was impossible to shake off the spiritual shackles of communism on him. He was constantly haunted by the question of "Where am I?" and the fight against his own shadow, i.e. the dark side that he can never get rid of. In a word, the novel articulates the inner world struggle of the Albanian intellectuals challenged by identity problem.

Agamemnon's Daughter denounces the communist tyranny and absurdity. The protagonist, a young Western-oriented intellectual, bemoans losing the love of the daughter of Enver Hoxha's designated successor. As compensation, he got an

\footnotetext{
${ }^{1}$ Almost all of Kadare's works have been published first in Albanian. Hija is an exception. It was first published in French in 1994 and in Albanian in 2003. No English translation is available.

2 The novel was translated into English by David Bellos from French version (2003) and published by the Arcade Publishing in New York in 2006. Kadare claims that Agamemnon's Daughter was written in mid-1980s, but judging from the time of the novel's first publication and taking into consideration Kadare's inclination to rewrite his works, it is doubtful how much of the novel was originally written in mid-1980s.
} 
invitation to watch the May Day parade from the Grandstand where only important guests are seated. The young man's acceptance of invitation refers to Kadare's agreement of collaboration with the Albanian communist regime. In this sense, it is comparable to Kadare's another short novel Shkaba (The Eagle, 1995), ${ }^{1}$ in which a young man sacrificed his flesh and soul to an eagle in order to return to this world from the underground world. Kadare's two short stories are included in Agamemnon's Daughter: "The Blinding Order" and "The Great Wall". The former is a parable of terror induction in the Ottoman Empire, whereas the latter depicts a chilling duet in the $14^{\text {th }}$ century between a Chinese official and a soldier of Tamerlane's invading army. The book reflects the author's Orientalist discourse and his desire for Albanian nation to identify with the West.

In September 1990, right before the collapse of the Albanian communist regime, Kadare flew to France for political asylum. Soon after that, Kadare completed his personal chronicle entitled Nga një dhjetor në tjetrin (1991, literally From One December to the Next, known in English as Albanian Spring: the Anatomy of Tyranny) $^{2}$ to show his pro-Western stand and to portray himself as a fighter for democracy. The book covers the period from December 1989 to December 1990. In it Kadare published his reflections on the Stalinist dictatorship in Albania, and his correspondence with the former Albanian President Ramiz Alia in May 1990, by which Kadare attempted to persuade Alia to undertake daring steps towards democratic reformation. The English title of the book suggests that Albania, having suffered the severe winter of the most tyrannical communist rule, was finally about to see the spring of democracy. Kadare portrays himself as the herald of the Western

\footnotetext{
1 The novel is available in Dutch (1996), French (1996) and Italian (2007), but unfortunately not in English.

2 The English translation was done by Emile Capouya from the French and published by Saqi Books in 1995 in London. It was published in Albanian for the first time in 2009 in Volume 20 of the latest complete collection of Kadare's works
} 
democracy in order to gain legitimacy to lead his people toward a new political identity.

In 1991, Pesha e kryqit (The Weight of the Cross) was published as a continuation of Ftesë në studio (1990, Invitation to the Studio). ${ }^{1}$ Here the author compared his experience in the communist Albania as bearing the weight of the cross. Together with Albanian Spring: the Anatomy of Tyranny, they form a kind of politico-literary trilogy, where Kadare drew a clear line with Communism, portrayed himself as a political dissident and reiterated his view of Albanian identity, that is, Albania was originally part of Europe and should now return to Europe. Kadare published these books in a hurry in order to defend himself at the critical time of Albania's political re-orientation, but, as pointed out by Robert Elsie, these works are "not devoid of the 'below the belt' polemics and petty vendettas ... [and] raise more questions as to Kadare's role in Albanian public life" (560) . ${ }^{2}$

Kadare produced quite a number of new works after the fall of communist regime in Albania in 1991, but none of them are as powerful as his previous masterpieces such as The Three-Arched Bridge, The Broken April and The Palace of Dreams. Among Kadare's novels of the post-communist period, we can mention Piramida (The Pyramid, 1992), Spiritus (Spirits, 1996), Tri këngë zie për Kosovën (Three Elegies for Kosovo, 1998), Lulet e ftohta të marsit (Spring Flowers, Spring Frost, 2000), Pasardhësi (The Successor, 2003), etc. ${ }^{3}$

The Pyramid, Spirits and The Successor treat the theme of communist

\footnotetext{
${ }^{1}$ Ftesë nё studio was published shortly before Kadare's departure for France. It contains thirty-two poems written by the author, verses translated by the author from Greek, Chinese, French, Romanian and Russian, as well as a series of the author's reflections on literature, the arts and current events. Pesha e kryqit was first published in French in 1991. It was not published in Albanian until 2009, in the $20^{\text {th }}$ volume of the complete collection of Kadare's works. Neither of the two works is available in English.

2 Robert Elsie, History of Albanian Literature, New York: Columbia University Press, 1995.

${ }^{3}$ Of these works, only Spiritus is not available in English. The Pyramid is translated by David Bellos from French and published in 1996, New York: Arcade Publishing. Three elegies for Kosovo is translated by Peter Constantine from Albanian and first published in 2000, London: Harvill Secker. Both Spring Flowers, Spring Frost and The Successor are translated by D. Bellos from French, New York: Arcade Publishing, respectively in 2002 and 2005.
} 
totalitarianism and especially the dictatorship in Albania. The Pyramid made its initial appearance in 1991 in the Albanian democratic newspaper Rilindja Demokratike (Democratic Rebirth). It was rewritten after Kadare settled down in Paris. By depicting the misery of tens of thousands of the Pharaoh's subjects in the process of constructing the Great Pyramid of Cheops, the novel reveals the destructive effects of the ruler's absolute power. The way the Pharaoh ensures his rule is analogous to Hoxha's obscurantist policy and his political purges. The pyramid is employed as a symbol of the oriental absolute power, a sharp contrast to the Western democracy.

In Spirits, Kadare tells an absurd story in the late phase of Hoxha's rule when the ruler was losing his sight. A group of foreigners in Albania heard about the capture of a spirit, which turned out to be a bugging device that the secret police forgot to remove from a murdered actor's jacket. The novel ridicules Hoxha's efforts of creating a perfect surveillance system to safeguard his rule. The title itself is ironic: the atheist regime that banned all religious practices is being haunted by a spirit planted by itself under the ground.

The Successor is a continuance of Agamemnon's Daughter. It is based on a historical event in 1981, the alleged suicide of Mehmet Shehu, the former Albanian prime minister and the designated successor of Hoxha. Whether Shehu killed himself or was murdered remains an enigma. Through a variety of perspectives, including the successor's own perspective from beyond the grave, the book gives a creepy account of the political conspiracies and the atmosphere of terror in the communist Albania.

In late 1990s, when the Kosovo problem was being increasingly internationalized, Kadare found it imperative to play a role in this process. The novel Tri këngë zie për Kosovën (Three Elegies for Kosovo, 1998) was written to demonstrate Kadare's view on the conflict between Serbs and Albanians. It consists of three inter-related stories 
centered on a famous battle that took place in Kosovo in 1389. Presenting the anti-Ottoman coalition army as constituted by Albanians, Bosnians, Romanians and Serbs, the novel serves as a counter narrative of the Serbian claim that Serbs alone fought in the 1389 Kosovo Field War against Turks. The story of two war minstrels, one Albanian and one Serb, illustrates that Kosovo has been the root of Serb-Albanian hostility since the ancient time and that the memory of enmity is ever-lasting for the two peoples, even when they are allied to fight against a common enemy. While emphasizing the Balkans as the origin of Western civilization, the book also reinforces the Western stereotype that the Balkans is a place of backwardness and conflicts. At the end of the novel, the Sultan's blood and viscera buried in Kosovo were blamed to be the culprit of endless Balkan quarrels and killings. By this, Kadare makes the point that the Balkan people should get rid of the Ottoman heritage and identify with Europe for a peaceful better life.

Living in France, Kadare keeps himself well informed about the changes in Albania. The novel Lulet e ftohta e marsit (Spring Flowers, Spring Frost, 2000) deals with the Albania's social problems in late $20^{\text {th }}$ century, the rebirth of blood feud in particular. Albania's transition from communism to democracy was accompanied with more social unrests than the other former Eastern European countries. ${ }^{1}$ In 1997 , the failure of the pyramid investment schemes brought the country into anarchy and brought back the blood feud phenomenon. Disappointed with the reality, many Albanians became nostalgic of the social security under the communist regime. It was in such a context that Spring Flowers, Spring Frost was written. The protagonist Mark finds himself caught between the long-awaited democratic freedom and the new social

\footnotetext{
${ }^{1}$ I have excluded the Yugoslavia's bloodbath under Milosevic when I talk about the transition from communism to democracy in the former Eastern European countries. There are two reasons for this exclusion. First, Yugoslavia was rather different from the other Eastern European countries therefore was not considered as a true communist country within the Eastern Bloc. Second, Yugoslavia's troubles should be viewed as civil war rather than social unrest, i.e. one can't suggest that Yugoslavia was transitioning to democracy under Milosevic.
} 
turbulence. Things like the involvement of his girlfriend's brother in a blood feud, the mysterious disappearance of his friend, the sudden death of his boss, etc. kept disturbing him, making him wonder whether he had chosen the right career as an artist. In a lunacy-like state, he imagined himself become a police chief, the job his father wanted him to do. Mark's confusion about personal identity reflects the dilemma of the Albanian people in choosing their national identity. The title of the novel has a metaphoric meaning: the newly planted democratic flowers in Albania are threatened by frost and Europe should take due measures to protect them.

With Albania's increasing aspiration for joining the EU, the claim of the Albanian nation's European identity has gained wide support among Albanians. Over the past two decades, Kadare continues to denunciate the communist totalitarianism, which he thinks is necessary in the process of Albania's Westernization. ${ }^{1}$ From Kadare's latest novels on this theme we can mention Aksidenti (The Accident, 2008), Darka e gabuar (The Wrong Dinner, 2008, title of the English version: The Fall of the Stone City), E penguara (The Prohibited, 2009) etc. ${ }^{2}$ Apart from fictions, Kadare also proclaims his opinions in essays or interviews. For instance, in 2006, Kadare published the essay "The European Identity of Albanians", in which he argues from different perspectives that Albania belongs to Europe. ${ }^{3}$ This essay is in fact a response to Rexhep Qosja's criticism of Kadare's previous remarks on the Albanian national identity. As a result, it triggered an even more heated debate between Kadare and Qosja.

\footnotetext{
${ }^{1}$ Asked in November 2008 on the Albanian ALSAT TV interview what he thinks is the Albanians' attitude toward the past regime, Kadare said it is required that all the ex-communist countries denounce the communist crimes as a process to push forward these countries. He said that Albania lagged behind in this aspect and should find a way to solve this problem. (The original text: - Cili është qendrimi që sipas jush po mban shoqëria shqiptare për regjimin e kaluar? - Qendrimi duhet të jetë i qartë, ende nuk është. Është e kuptueshme. Është kërkuar nga të gjitha vendet ish komuniste të dënojnë krimet e komunizmit si një proces që do të cojë këto vende përpara. Ne jemi ndër më të fundit për të mos thënë $\mathrm{i}$ fundit, prandaj shoqëria shqiptare duhet ta zgjidhë këtë problem.) http://www.alsat.tv/lajme-nga-vendi/kadare-rrefen-ne-alsat-per-vepren-e-tij-te-fundit-marredheniet-me-enver-hoxh en-dhe-kosoven.html Accessed on January 25, 2010.

${ }^{2}$ Accidenti and Darka e gabuar have been translated into English by John Hodgson. The former's English version is titled as The Accident whereas the latter as The Fall of the Stone City. E penguara is not available in English yet.

3 Ismail Kadare, Identiteti Evropian i Shqiptarëve (The Albanians' European Identity). Tirana: Onufri, 2006.
} 
As can be seen from above, Kadare has always treated the Albanian national identity as the major theme of his works. It is evident that Kadare's political view of the Albanian national identity has changed dramatically over the past half a century. Many factors have contributed to Kadare's political changes, such as the relationship between superpowers, Albania's relations with other countries, the domestic situation within Albania, Kadare's own experience and political observations, etc. Kadare is capable of adapting himself to different political situations. His life and works can serve as a miniature of Albania's history since the Second World War. By examining the Others that have been constructed in Kadare's works and analyzing the changes of Kadare's political position concerning the Albanian national identity, we can get a deep insight into the factors that have affected the (re)construction of the Albanian national identity, the role of "Other" in shaping the Albanian national identity, and the political nature of the Albanian national identity.

\subsection{A controversial figure}

The controversy over Ismail Kadare is related mainly to two issues: first, Kadare's attempts to portray himself as a dissident of the Albanian communist regime, and second, Kadare's attempts to assure the Albanians of their nation's pure European identity. In other words, the dispute concerning Kadare is an issue of identity on two levels: on the individual level, i.e. Kadare's personal identity, and on the collective level, i.e. the Albanian nation's identity. These two identities are closely interrelated.

Kadare knows how to orient himself politically and select the right forces to ally with. His relationship with the Albanian communist regime illustrates that he is adept at making timely adjustments of his political affiliation. As a privileged writer in the communist Albania, Kadare voluntarily or involuntarily served the political purposes 
of the regime. During the 1960s and 1970s, when Kadare was young and the communism was in its heyday, Kadare wrote with full enthusiasm to laud the social progress under the Albanian Labor Party's leadership (called Albanian Communist Party before 1948). His works played an important role in strengthening people's consciousness of their national-communist identity. However, during the 1980s or even as early as in late 1970s, though still favored by the regime, Kadare was becoming increasingly aware of the decline of communism in Albania and worldwide. Politically sophisticated, Kadare knew he should prepare himself for the days when communism comes to its end. Therefore, during the 1980s, while continuing to pay tributes to Enver Hoxha from time to time, Kadare wrote multilayered fictions, some of which even with obvious anti-communist allegories. After fleeing to Paris in 1990 for political asylum, Kadare did two things to identify himself with the West: portraying himself as a dissident of Hoxha's regime (though he never claimed to be so) and attacking the communist totalitarianism.

What makes Kadare a controversial figure is that he seeks continuously to turn himself into a victim and a hated thorn of the Albanian communist regime. After he settled in Paris, Kadare did his utmost to transform his identity through interviews with David Binder (1990) ${ }^{1}$, with Robin Smyth $(1991)^{2}$, with Alain Bosquet (1995), ${ }^{3}$ with Shusha Guppy $(1998)^{4}$, and with Denis Fernandez Recatala (1999) ${ }^{5}$. For example, in his interview with Binder, he denied that he had enjoyed any protection from Enver Hoxha:

\footnotetext{
${ }^{1}$ David Binder, "Albanian Exile Writer Sees Reform," New York Times, December 6, 1990, p. 2.

2 Robin Smyth, "Laying Siege to the Palace of Dreams," London: Observer, April 7, 1991, p. 62.

${ }^{3}$ Ismail Kadare and Alain Bosquet, Dialogue avec Alain Bosquet (Dialogue with Alain Bosquet). Paris: Fayard, 1995.

${ }^{4}$ Ismail Kadare and Shusha Guppy. "Ismail Kadare: The Art of Fiction CLIII." Paris Review 40, no. 147 (summer 1998): 195-217.

${ }^{5}$ Ismail Kadare and D. Fernandez-Récatala, Temps Barbares: De l'Albanie au Kosovo: entretiens, Paris: Archipel, 1999. (Translated into Albanian by Artan Babaramo, Alket Çani and Luan Canaj, Kohë barbare: nga Shqipëria në Kosovë: Biseda. Tirana: Onufri, 1999).
} 
For twenty years they have attacked me continually. Do you believe that someone in Albania could have been attacked in such a harsh manner if he had had the real protection of Enver Hoxha? (Binder, 2)

In his interview with Sh. Guppy, Kadare presented himself as an anti-regime dissident that continuously damaged the regime with his literary dagger.

In Albania everybody knew that I was an anti-regime writer. And the fact that the regime couldn't condemn me gave courage to others. That is the fundamental function of literature: maintaining the moral torch.

Every time I wrote a book, I had the impression that I was thrusting a dagger into the dictatorship, while at the same time giving courage to the people. (Guppy 213-214, italic emphasis mine)

Obviously, this is not true. Though in the 1980s Kadare wrote some works which can be interpreted as anti-communist, he certainly did not write every book to "thrust a dagger into the dictatorship". Kadare's contribution to the construction of the communist Albania is clearly acknowledged by the Albanian former president Ramiz Alia in his letter to Kadare in 1990.

Your works are dedicated to the defense of our native country, to its freedom and independence, as well as to the heroic struggle of our Party and to Comrade Enver Hoxha's efforts to preserve Albania's sovereignty. (I am thinking of The General of the Dead Army, The Drums of Rain, The Great Winter, What Do the Mountains Think? Eagles Fly High, and The Concert [...] etc.) These books all redound to your honor, not simply as a writer but as a combatant, as patriot, and as a communist. The people love your work, and the Party has always held your books in high esteem. You must not forget what Comrade Enver Hoxha did for you, nor the marked preference that I have always accorded you. (Kadare, Albanian Spring, 105)

Of course Kadare himself is aware of his service to the Albanian communist regime. But why does he seek to present himself as a dissident? ${ }^{1}$ Three reasons

\footnotetext{
${ }^{1}$ On several occasions, for instance when asked in an interview in November 2006 on Albanian "TV Klan" whether he had ever tried to present himself as a dissident, Kadare answered, "Absolutely not. Others have said 
account for Kadare's attempt. First, when the West was scouting for influential voices from the Eastern communist camp to denounce the communist totalitarianism, to disseminate Western values and to celebrate their victory over the communist East, the label of dissident or anti-communist regime writer would help Kadare to be better accepted by the West. The depiction of human nature distortion from a "dissident" perspective, the gloomy pictures of life and the exposure of psychological fear under the communist rule have contributed immensely to Kadare's popularity among Western readers. In 1992, Kadare was awarded the Prix mondial Cino Del Duca ${ }^{1}$. In 1996 he became a lifetime member of the Academy of Moral and Political Sciences of France. Kadare's success in winning the inaugural Man Booker International Prize in 2005 and the Prince of Asturias Award for Literature in 2009 is the best recognition of his masterful literary attacks on communist totalitarianism. These international prizes, in turn, help to consolidate Kadare's position as the best Albanian writer.

Second, the identity of dissident can exempt him from moral accusation. Accused of ingratitude to the communist regime, Kadare argues that he was protected and privileged by Hoxha because he was internationally well known and the regime was afraid of the political pressure from the international community. $\mathrm{He}$ asserts that instead of collaboration, he wrote works that were like "daggers" to the regime. Presenting himself as a dissident is important for Kadare to prove that he is an honest and faithful person, who has consistently fought with his pen against communism.

Third, the identity of dissident will grant him the political capital he needs to continue his role as the leading Albanian intellectual in the post-communist era. In the Central and Eastern European countries, the intellectuals and politicians once

this, and I could not do anything when foreign journalists wrote 'The dissident author Ismail Kadare..." However, it should be noted that there is difference between trying to present himself as a dissident and labeling himself a dissident.

1 The Prix mondial Cino Del Duca (Cino Del Duca World Prize) is an international literary award established in 1969 in France by Simone Del Duca (1912-2004) to continue the work of her husband, publishing magnate Cino Del Duca (1899-1967). It rewards authors who have contributed to conveying messages of modern humanism. 
persecuted were rehabilitated and compensated in the 1990s for the ill-treatment they suffered under the communist regimes. The most popular politicians in the post-communist years were those who had previously opposed communism. In the new political context, intellectuals who made negative observations of communism are better qualified to hold the pro-Western banners. Therefore once the communist regime started to collapse, Kadare took actions to put as many as possible his previous multilayered works as the foundation upon which he could build his new identity: the leader of Albanian nation's Westernization, or in Kadare's words, the leader of Albanian nation's “return to Mother Europe". ${ }^{1}$

The issue of Kadare's dissident status aroused a debate, both within and without Albania. Some critics consider Kadare as a hidden dissident from the very beginning of his literary career. For example, the Australian scholar Peter Morgan argues that Kadare is a dissident under Hoxha's communist regime. According to Morgan, “As a result of the publication of The General in France in 1970, Kadare became a name on the world stage of Eastern European dissidents" (38). ${ }^{2}$ In 2010, he published a book titled Ismail Kadare: The Writer and the Dictatorship 1957-1990 to support his point of view. He calls Albanian communist regime's act of sending off the post-war generation of "new men" to the Soviet universities a fatal mistake, because when Kadare was repatriated to Albania, he had already seen the consequences of Khrushchev's reforms (Morgan 40). ${ }^{3}$ Indeed, the political changes in the Soviet Union after Stalin's death and the Pasternak incident immensely impressed young Kadare, which as a result contributed to the formation of his strong self-protection consciousness in literary creation. Between 1960s and mid-1980s, Kadare constantly

\footnotetext{
${ }^{1}$ Kadare retouched, renamed and reinterpreted some of his works. For example, he renamed The Castle as The Siege, tried to negate and bury in oblivion The Wedding, and highlighted his poem "The Red Pashas" to prove that he was a dagger to the regime.

2 Peter Morgan, "Translation and Dictatorship: the Case of Ismail Kadare," The AALITRA Review: A Journal of Literary Translation, No.2 (Melbourne: Monash University, 2010), pp. 37-41.

${ }^{3}$ Peter Morgan, Ismail Kadare: The Writer and the Dictatorship 1957-1990. London: Leganda, 2010.
} 
resorted to historical and folkloric stories to convey allegoric meanings. Like all the other pro-Kadare critics, Morgan acclaims Kadare's ability of creating subtle political allegories to attack the totalitarian rule in Albania. In this light, Kadare's masterpiece General of the Dead Army is interpreted as an unfriendly work against Hoxha's regime. The ominous rain, the foggy cold weather and the sullen atmosphere in the novel are seen as elements in strong contrast to the bright socialist life depicted by Kadare's contemporary writers.

Other critics cannot ignore Kadare's denial of having been a collaborator of the Albanian communist regime. For example, Noel Malcolm points out that "a simplistic post-1990 interpretation offering only the crude alternatives of party hack vs. persecuted rebel has warped the judgment not only of Kadare's critics but also of the writer himself” (24). ${ }^{1}$ In 1992, many Muslim Albanian-Americans gathered in the Albanian Islamic centers around New York protesting against Kadare's remarks on Islam and denouncing his collaboration with the former Albanian communist regime (Vickers \& Pettifer 104). ${ }^{2}$ Some people even call Kadare "Hoxha's spy". ${ }^{3}$ The accusation was proven by the former head of Albanian intelligence service "Sigurimi" Zylyftar Ramizi (1982-1990 as head of Sigurimi), who exposed that Kadare served as a Sigurimi agent under the pseudonym of "general". ${ }^{4}$ Rexhep Qosja, the most prominent Kosovo intellectual, maintains that Kadare is a myth created by Hoxha's communist regime. ${ }^{5}$

\footnotetext{
${ }^{1}$ Noel Malcolm. "In the Palace of Nightmares." Review of The Three-Arched Bridge, by Ismail Kadare. New York Review of Books 44.7 (6 Nov. 1997): 21-24.

${ }^{2}$ Miranda Vickers \& James Pettifer. Albania: From Anarchy to Balkan Identity, New York: NYU Press, 1997.

${ }^{3}$ Renata Dumitrascu published her article "Kadare is no Solzhenitsyn", denouncing Kadare's attempt to present himself as a dissident. http://www.mobylives.com/Dumitrascu.html accessed on March 12, 2009. Kaplan Resuli wrote two books, The true face of Ismail Kadare and "The lies do not alter the truth, which reveal that Kadare served as the regime's spy. http://ismailkadaretruth.blogspot.com/2008/09/nobel-prize-nominee-kadare-was.html accessed on March 12, 2009.

4 "Kadare has been an early associate of the state security? (Kadareja ka qenë bashkëpunëtor i hershëm i Sigurimit të Shtetit?)", Koha Jonë (Our time), May 25, 1996.

5 "Qosja dhe Kadare sërish përballë" (Qosja and Kadare again face to face), August 1, 2008, online source at http://www.balkanweb.com/gazetav5/artikull.php?id=41023.
} 
Between the pro-Kadare group and the anti-Kadare group are those who prefer to take the issue moderately. Robert Elsie, for instance, regards Kadare as a "profoundly dissident writer" who led a "collaborationist life". In order to quench the debate over Kadare's personal identity, Elsie points out that Kadare "gave his unconditional support to the political system from which he himself no doubt suffered. ... A political analysis of conformity and dissent in his prose must be left to the future" (562-563). ${ }^{1}$

There are other people, though, who are not interested in the debate per se. They view the debate as meaningless. In their opinion, what matters is that Kadare is an excellent writer, and this has nothing to do with whether he is a dissident or not. Commenting on Kadare's artistic value, Fatmir Alimani writes, "he was born of legends and legends are born of him. For him, actuality becomes legend, antiquity, and future" (195). ${ }^{2}$ According to Alimani,

Kadare's imagination contains something fascinating, awakening, provocative, ambiguous, and emancipating. In order to make a literature in the true sense, he uses words that sound differently from their usual ways. [...] In this way the words create an artistic narrating system, in a multilayered link where the oral traditions, fantastic genre and magic realism melt into one unique narration that can be called Kadarean. (213)

Indeed, the Kadarean style of narration in works such as General of the Dead Army and The Palace of Dreams has successfully impressed readers with its masterful psychological depictions. Moreover, based on Albanian culture and history, Kadare's works provide insights to many of the fundamental questions of humanity, such as life and death, war and peace, civilization and barbarism, conscience and immorality, etc. Nevertheless, literature is never separable from politics, and this is more than true for Kadare's literary creation. Even Kadare's repopularity is closely related to politics. Obviously, winning the International Man Booker Prize in 2005 is a turning point in

\footnotetext{
${ }^{1}$ Robert Elsie, History of Albanian Literature. New York: Columbia University Press, 1995.

${ }^{2}$ Fatmir Alimani, Katër K: Kavabata, Kundera, Kadare, Kafka (The Four K: Kawabata, Kundera, Kadare, $K a f k a$ ), Tirana: Onufri, 2004.
} 
Kadare's life. Before that, as Elsie observed in 2004 in his review of Kadare's novel The Successor, Kadare "suffered from public indifference since his return to Tirana" (149). ${ }^{1}$ Kadare's repopularity among Albanians occurred when Albania was in urgent need to be recognized by the West. Albania shifted to democratic system in 1991 in hope for a better life. Ever since then, joining the Western camp has been the top priority of the Albanian government and people. But to their disappointment, things did not turn out as they had wished. After years of democratic transition, Albania was still the poorest country in Europe and unknown to the world. As mentioned in the American movie Wag the Dog (1997), "Nobody knows anything about Albania". To be better known by the world, Albanian nation needs someone like Kadare who has gained international recognition. The more Kadare's name is heard as a great Albanian writer, the more Albanians feel proud of him. Therefore, for most Albanians, as long as Kadare can serve the present national interests, his past can be ignored. However, to judge Kadare only from artistic perspective or out of national sentiment is prone to understanding Kadare and his works in a biased way. The debate on Kadare is helpful for us to understand Kadare and his works more comprehensively and to get a deeper insight in terms of Kadare's political motivation for writing, either for his own interest or for the Albanian nation's interest as a whole. Evading the debate, for whatever reason, is to the detriment of the study of Kadare's political role as the leading Albanian intellectual. In other words, examining the arguments of both sides of the debate can contribute to the study of Kadare's personal political re-orientation, the Albanian nation's identity reconstruction as well as the deep social and political background of the changes.

Kadare's repopularity irritated those who dislike Kadare's political opportunism

\footnotetext{
${ }^{1}$ Robert Elsie, Review of The Successor, by Ismail Kadare, World Literature Today, vol. 78, Sep-Dec 2004, Iss. 3/4, p. 149 .
} 
and his personality. In 2006, Rexhep Qosja, Kosovo's most prominent intellectual, published Ideologjia e shpërbërjes (Ideology of Disintegration), in which he expressed his concern that the three ongoing attempts would disintegrate the Albanian nation: the attempts to change the standard Albanian language in order to correct the injustice done to gegërisht during the communist regime; ${ }^{1}$ the attempts to overemphasize the predominance of one religion (Catholic) over the other two (Islam and Orthodox); and the attempts to create a Kosovo identity as independent from that of Albania. Talking about the problem of overemphasizing the Western Christianity, which is actually the focus of his booklet, Qosja criticized some politicians and intellectuals for making improper remarks on this issue. Though Qosja never pointed out clearly who made these remarks, Kadare had no slightest doubt that he was the person Qosja refered to.

Early in 1990, Kadare predicted, as shown in his letter to the former Albanian President Ramiz Alia, that all the Albanian people, including the Kosovo Albanians, will eventually turn to Christianity. ${ }^{2}$ Later on in different situations, Kadare openly expressed his view that Christianity, the religion of Albanian ancestors, should be the religion of the Albanian nation, whereas Islam, which came as a consequence of Ottoman occupation, should be discarded because it is a foreign thing imposed on the Albanian nation. Therefore, Kadare was aware that he was the target of criticism of Qosja's Ideology of Disintegration. He reacted quickly with "Identiteti europian i shqiptarëve: sprovë" ("The European Identity of Albanians: Essay”), in which he argues that factors such as geography, language, race and religion are unchangeable variables to prove Albanian nation's European identity. According to Kadare, a

\footnotetext{
${ }^{1}$ The Albanian language has two major dialects, the southern dialect toskërisht, and the northern dialect gegërisht. Kosovo and the northern Albania speak gegërisht. The modern standard Albanian was formed on the basis of toskerrisht, partly due to the fact that most of the important Albanian Communist figures came from the south.

${ }^{2}$ See Kadare's Albanian Spring 1995: 34.
} 
nation's identity cannot be altered as a result of foreign occupation. He insists on Albanian nation's European identity, no matter how long it stayed under the Oriental Ottoman occupation. He reiterates that Qosja's theory of Albanian nation's half-Eastern and half-Western identity provides no good service to Albanian nation's interest.

Kadare's remarks drew wide public attention and caused a heated discussion. In Albania, Dritëro Agolli, former-chairman of Albanian Writers' Union, criticized Kadare's claim, arguing that Albanians today no longer speak the same language and possess the same cultural traits as their ancient ancestors did, nor will their descendants in the future. ${ }^{1}$ Whereas in Kosovo Rexhep Qosja raised his voice vehemently to refute Kadare's allegations. The polemic on Albanian national identity between Kadare and Qosja, the two most prominent Albanian leading intellectuals and each supported by their followers, was covered extensively in 2006 by the media in Albania and Kosovo.

Actually, before the Kadare-Qosja debate in 2006, studies on Albanian nation's identity and Kadare's role in this respect had already started in academia. For instance, in Albanian Identities: Myth and History (2002), Kadare's role as the central literary figure in the national identity reconstruction during the communist regime is reexamined critically by Albanian and foreign scholars. ${ }^{2}$ According to Fatos Lubonja, Kadare wrote with a clear objective to support the regime's national-communist politics and contributed significantly to the building of myths that glorify the heroism of Albanian nation: the heroic fight of ancient Illyrians against Roman invasion, the $15^{\text {th }}$ century Skanderbeg's fight against Ottomans, the $19^{\text {th }}$ century Albanian National

\footnotetext{
1 See "Mbi debatin për identitetin shqiptar" Intervistë (Over the debate about Albanian identity, Interview) Shqip, May 16, 2006.

${ }^{2}$ Stephanie Schwander-Sievers and Bernd Fischer, (eds.) Albanian Identities: Myth and History. Bloomington: Indiana University Press, 2002.
} 
Renaissance, as well as the partisan war and socialist construction led by the Communist Party (95-100). ${ }^{1}$ Another example worth mentioning is Enis Sulstarova's study on the discourse of Albanian nation's identity, from the Albanian Renaissance in late $19^{\text {th }}$ century up to the $21^{\text {st }}$ century. In his book Escaping from the East: Albanian Orientalism from Naimi to Kadare (2006), Sulstarova dedicated a whole chapter to the issue of Kadare's Orientalist discourse. He argues that Kadare has followed the Orientalist manner of the intellectuals of the Albanian National Renaissance in treating the Albanian national identity, though the representation of the Oriental Other in Kadare's works is different due to political changes in Albania. ${ }^{2}$

Qosja's criticism focuses on Kadare's dichotomist mentality and his essentialist view of national identity. Indeed, Kadare tends to address the Albanian national identity issue with an "either-or" approach. Samuel Huntington published "The Clash of Civilizations" in 1993, where he stated that religious affiliations would play a major role in the post-Cold War inter-state relations and the civilization clash between Christian West and Islamic East would be the sharpest. ${ }^{3}$ Kadare seems to have become aware of the post-Cold War religious clash even earlier than Huntington, as it was in 1990 that he expressed his conviction that the whole Albanian nation would convert to Christianity. Arguing against Qosja in 2006, Kadare insisted that Albania should get rid of the status of an in-between place, because such an identity has nothing to be proud of.

The usual cliché that Albania can be conceptualized as an intermediary place, sandwiched between the East and the West, a civilization belonging to neither side, the 'neither nor' place, does not honor us in any way. $(55)^{4}$

\footnotetext{
1 Ibid. Fatos Lubonja, "Between the Glory of a Virtual World and the Misery of a Real World," pp. 95-100.

${ }^{2}$ Enis Sulstarova, Arratisje nga lindja: Orientalizmi shqiptar nga Naimi te Kadareja (Escape from the East: Albanian Orientalism from Naim to Kadare). Tirana: Dudaj, 2006.

3 Samuel Huntington, "The Clash of Civilizations," Foreign Affairs 72.3 (1993): 22-49.

${ }^{4}$ Ismail Kadare, Identiteti Evropian i Shqiptarëve (The Albanians' European Identity). Tirana: Onufri, 2006.
} 
Criticizing Qosja's argument as "neither nor" cliché, Kadare uses as arguments Albania's geographic position within the European continent and its deep cultural ties with Europe before the Ottoman occupation. The pantheist culture of the ancient Illyrians is ignored. Instead, Christianity is counted as the initial religion of the Albanian nation, which according to his primordialist/essentialist view will never change or be lost, even after a long time under the Ottoman rule.

As a response, Qosja published a series of essays, including "Disregarded reality: a Critical Insight on Ismail Kadare's viewpoints on Albanian identity"1 , "The racist ideas of Ismail Kadare", 2 "Albanian identity and culture", 3 "Ismail Kadare's Muslim-phobia", "Kadare, Europe and our life", 5 etc. In contrast to Kadare's point of view, Qosja contends that one must look at the issue of the Albanian identity realistically and accept it as the outcome of irreversible historical processes. In his essay "Kadare, Europe and our life", Qosja points out "It is beyond any doubt that the way Ismail Kadare has chosen to prove our European identity is wrong because it seeks to deprive it from elements from which it cannot be deprived ultimately". Qosja holds that the long Ottoman rule in Albanian history cannot be erased and its legacy cannot be ignored. He calls on the Albanians to take up the mission of a borderline nation and play a positive role in mitigating the East/West dichotomy. Taking Bosnia as an example, Qosja expresses his belief that the Muslim identity of the Albanian majority would not hinder Albania or Kosovo's entry into the EU. The factors impeding Albanian nation's integration into Europe, Qosja emphasizes, are the

\footnotetext{
1 The original title in Albanian is "Realiteti i Shpërfillur: vështrim kritik mbi pikëpamjet e Ismail Kadaresë për identitetin shqiptar". First published in the Albanian daily paper Shqip (Albanian) on May 2, 2006, later published in the form of a booklet by the publishing house TOENA, in Tirana, 2006.

2 The original title in Albanian is "Idetë Raciste të Ismail Kadaresë". Published in Albanian daily paper Shqip, May 3, 2006.

3 The original title in Albanian is "Identiteti shqiptar dhe kultura". Published in Albanian daily paper Shqip, May 4, 2006.

${ }^{4}$ The original title in Albanian is "Myslymanofobia e Ismail Kadaresë". Published in Albanian daily paper Shqip, May 5, 2006.

5 The original title in Albanian is "Kadareja, Europa dhe jeta jonë". Published in Albanian daily paper Shqip, May 7, 2006.
} 
backward mentality and the political incompatibility with the EU standards, such as the remains of oriental despotism, the primitive tribalism and the communist totalitarianism. Commenting on Kadare's search for the Christian roots, Qosja calls it "the quest of recently converted Communists that would find this a profitable enterprise for their political capital". ${ }^{1}$

Kadare's most vulnerable point in the debate is his attitude toward Islam. During the communist time, Kadare's anti-Islam narration was knitted into his anti-Ottoman works, whereas after the 1990s, he started to openly attack Islam. In 1992, Kadare claimed that "Albanians are among those people who have suffered equally from Communism and from Islam", which as a result, caused strong protest from the Albanian Muslim Diaspora in New York (Vickers \& Pettifer, 1997:104). In The European Identity of Albanians Kadare once again criticized Albania's relations with the Islam countries. Kadare's remarks on Islam reveal his oversimplified understanding of religion. More importantly, they reflect the political changes in Albania and the major ideological conflicts in the post-Cold War international arena.

The Albanian Democratic Party has changed its attitude toward Kadare over the past two decades. Kadare himself disclosed two facts: one is that in 1994 the Albanian ambassador to Sweden formally asked the Nobel Prize Committee not to give the prize to Kadare; the other is that President Sali Berisha did not attend the ceremony of Kadare's permanent membership to the Academy of Moral and Political Sciences of France in $1996 .{ }^{2}$ It indicates that the government of that time was holding an unfavorable attitude toward Kadare. However, with Kadare's increasing recognition in the world, the Albanian government started to respond more positively to Kadare's achievements. After all, Kadare's political alignment fit with the Albanian

\footnotetext{
${ }^{1}$ Ibid.

2 "Kadare: Shqiptaret qe me penguan Nobelin" (Kadare: Albanians who impeded my way to the Nobel Prize), Dec. 2, 2008. http://lajme.shqiperia.com/lajme/artikull/iden/139616/titulli/Kadare-Shqiptaret-qe-me-penguan-Nobelin. 
government's political interest. Both Kadare and the Albanian government want to play down the factors that might distance Albanian nation from Europe, particularly the Muslim identity of Albanians. This concern is obvious in the former Albanian President Alfred Moisiu's speech in November 2005 where he said that Islam in Albania is superficial and that Muslim Albanians are Christian in the core because they were rooted in Christianity for 15 centuries before their Islam conversion. ${ }^{1}$ In their pursuit for Albania's admission to the EU, top Albanian officials have voiced their support for Kadare with regards to the issue of Albanian nation's identity. Sali Berisha even declared that "the Albanian national thinking goes through the works of Ismail Kadare", and "Kadare is a modern renaissance man" (Artan Puto, 2006: 27). ${ }^{2}$ The notable change of Albanian government's attitude toward Kadare further proves Kadare's political ability and his high value in the process of Albania's identification with the West.

As can be seen from above, the controversy over Kadare's personal identity and the debate on Albanian national identity are closely inter-related. For Kadare, a favored writer during the Albanian communist period, it is extremely important to realign himself politically. Presenting himself as a hidden dissident under communist dictatorship is a way of gaining popularity and legitimacy in the post-communist era. The anti-Kadare voices use Kadare's collaboration with the Abanian communist regime as evidence to argue against Kadare's legitimacy as a leading Albanian intellectual in the post-Cold War era. Nevertheless, Kadare regained popularity, and became the pride of his nation on the world stage. The polemics on Kadare and the Albanian national identity reflect the political regrouping and identity reconstruction

\footnotetext{
${ }^{1}$ Moisiu's speech on the Oxford forum is entitled: "The inter-religious tolerance in the tradition of Albanians". For information on and reaction to it, please refer to http://www.forumimusliman.org/tema10-11-05.gif and http://www.forumimusliman.org/english/pershtyp7.html

2 Artan Puto, "Fryma romantike dhe nacionaliste në debatin për identitetin shqiptar" ("The romantic and nationalistic spirit in the debate on Albanian identity"). Përpjekja (The Effort, weekly artistic-philosophical journal), 23: 13-33, 2006.
} 
after the collapse of communism in Europe. In other words, what we see is the post-Cold War imbalance between East and West shown in the cultural field of an in-between nation like Albania. As Pierre Bourdieau has pointed out, the field of cultural production is the arena where many actors clash in their quest to establish supremacy, authority and expertise (40-45). ${ }^{1}$

In short, the controversy over Kadare makes him more worthwhile to be studied in terms of the construction and reconstruction of Albanian nation's political identity. It makes the study of Kadare's works more desirable, particularly the original versions as they are the reliable sources for tracking the evolution of the Albanian nation's political identity over the past half a century. On the other hand, as an inevitable phenomenon in the process of a nation's re-identification in the democratic context, the controversy also provides us with different perspectives of looking at the national identity issue. It promotes our understanding of whether a nation's identity is determined by history, reality or the prospective national interest. Furthermore, it provides us a good chance to gain a deep insight to the role of intellectuals in the (re)construction of national identity.

\subsection{A case in point}

The research on Albanian national identity through the analysis of the Others as presented in Ismail Kadare's works has its value not only for the Albanian studies and the Balkan studies, but also for the examination of relevant theories. To be more specific, it is a case in point for mainly two reasons:

First, the history of Albanian nation, which is rather young as a modern nation but quite old as an ethnic group, provides a good case to examine the political nature of

\footnotetext{
1 Randal Johnson ed., The field of Cultural Production: Essays on Art and Literature, Cambridge: Polity Press, 1993.
} 
nation, the essence of national identity and the role of "Other" in the formation of national identity.

Second, the research on the Albanian national identity as it has been constructed in Kadare's works, particularly through the political rhetoric of Othering, can illustrate how literature is invoked as an essential means to make people believe what their nation is or is not.

As a typical Balkan nation, the Albanians have been greatly impacted in its history by the power shifts between East and West. After being conquered by the Roman Empire in $165 \mathrm{BC}$, Albania was ruled successively by the great empires to its west or east, roughly, five centuries under the Roman Empire, ten centuries under the Byzantine Empire and another five centuries under the Ottoman Empire, until it won independence in 1912. These empires have left remarkable imprints on Albanian nation, especially in terms of its religious beliefs. Before the Second World War, about $70 \%$ of the Albanian population were Muslim, 20\% Orthodox and 10\% Catholic. During the Albanian National Renaissance in the $19^{\text {th }}$ century, the Albanian elites attempted to abandon the Ottoman heritage and embrace the industrialized Western Europe. This process of westernization was interrupted because of the emergence of communism and did not restart until early 1990s. Like all the other small nations on the borderline between East and West, Albanians have been continuously forced to face the question of which side to identify with. They have to evaluate factors that would affect their national interest, such as ideology, domestic and international political situation, historic heritage, etc., and decide whether they are an Eastern nation, a Western nation or just a nation in-between.

The question we need to ask first is "What is a nation"? Theories on nation can be divided into two major schools: primordialism and constructivism. The former, 
represented by the 18th century German philosophers Herder and Fichte, contends that nations are ancient natural phenomena. Herder held that language is the key element of national identity, because "in it dwell its entire world of tradition, history, religion, principles of existence; its whole heart and soul" (qtd. in Oakes, 2001: 22). ${ }^{1}$ However, as early as after WWII, essentialism met severe challenges from scholars who asserted nation is a modern phenomenon constructed in the process of national identification, particularly as a result of the new printing technology. Negating the essentialist view of national identity as unchanging, constructivism put forward a more fluid approach. Anderson, for instance, is highly quoted for his theory that nation is "an imagined political community and imagined as both inherently limited and sovereign" (1991: 6), ${ }^{2}$ whereas Gellner is well known for his statement that "it is nationalism which engenders nations, and not the other way round" (1983: 55). ${ }^{3}$

Anthony Smith represents the neutral stand between the above two opposing strands. Smith offers his interpretations of the origins of the nation, acknowledging both its modern derivation and pre-modern origins. According to Smith, the pre-modern roots of nation are essential elements because nation is based upon a pre-existing ethnic community $(1986: 15,22-30) .{ }^{4}$ Likewise, in order to reconcile the two opposite views and advocate a realist approach, Satya Mohanty (2003: 398) suggests that identities can be both constructed and "real" at the same time. ${ }^{5}$

Of all the contemporary forms of collective identity, national identity is perhaps the most powerful and pervasive. This is affirmed also by Anthony Smith: "Today national identity is the main form of collective identification. Whatever the feelings of

\footnotetext{
${ }^{1}$ Leigh Oakes, Language and National Identity: Comparing France and Sweden. (in the series of Impact: Studies in Language and Society, Vol. 13) Amsterdam: John Benjamins, 2001.

2 Anderson, Benedict. Imagined Communities: Reflections on the Origin and the Spread on Nationalism. London: Verso, 1991.

3 Ernest Gellner, Nations and Nationalism. Oxford: Blackwell, 1983.

4 Anthony Smith, The Ethnic Origins of Nations, Oxford: Blackwell, 1986.

5 Satya Mohanty, "The Epistemic Status of Cultural Identity," in Identities, Race, Class, Gender, and Nationality, edited by Linda Martin Alcoff and Eduardo Mendieta, pp. 392-405. Oxford \& Berlin: Blackwell publishing, 2003.
} 
individuals, it provides the dominant criterion of culture and identity, the sole principle of government and the chief focus of social and economic activity" (1991: $70) .{ }^{1}$

Then what are the key elements for shaping national identity? Language, history, culture, religion, ideology, etc. are essential elements for national identity formation, language in particular. Those who share the same language tend to view each other as in-group members. However, it occurs that people speaking the same language differentiate themselves from each other. If it would be funny to see American movies with Australian or Canadian or British subtitles because there are some minor differences between them, it wouldn't be fun at all to see Serbian movies with Croatian or Bosnian subtitles, especially as a result of severe fighting which claimed numerous people's lives. Differences in religion, history and culture contributed to the re-identification of these people, but they were certainly highlighted or exaggerated for political and economic purposes.

The role of difference in constituting collective identity has long been emphasized ever since Emile Durkheim, the founder of sociology, who by comparing the suicide rates of different religious groups, of different European nations, and of other different social attachments such marital status, urban/rural life, etc. proved that the main determinants of suicide were social culture and social identity. ${ }^{2}$ In formulating social identity theory, Henri Tajfel et al. invented the terminology of "ingroup" and “outgroup", referring respectively to "us" and "them". ${ }^{3}$ As is the relationship between Self and Other, the lineation of an ingroup necessarily entails the delineation from an

\footnotetext{
1 Anthony Smith, National Identity, London: Penguin, 1991.

${ }^{2}$ Emile Durkheim, Suicide: A Study in Sociology. Trans. Spaulding, John A., and George Simpson, New York: Free Press, 1997. In this study, Durkheim compared the different suicide rates in religious societies such as Protestant, Catholic, and Jewish, in different European nation states such as France, Prussia, Austria, Denmark, Greece, in different marital statuses such as married and unmarried, in different areas such as urban and rural, and so on, based on which he reached the conclusion that the basic causes of suicide are social in nature.

${ }^{3}$ Henri Tajfel (ed.) Social Identity and Intergroup Relations .Cambridge, UK: Cambridge University Press, 1982.
} 
outgroup. In other words, the existence of 'us' requires the existence of 'them', be it real or imaginary, and only through the relationship to an outgroup Other can the identity of Self be constructed. In Chantal Mouffe's words, "collective identities can only be established on the mode of an us/them" (13). ${ }^{1}$

However, in the process of Self's identification, the Other does not only serve passively as an opposing signifier. In elucidating the Self as a product of social interaction, George H. Mead wrote: “The individual experiences himself as such, not directly, but only indirectly, from the particular standpoints of other individualized members of the same social group, or from the generalized standpoint of the social group as a whole to which he belongs" (1934: 138). ${ }^{2}$ In his research, Mead called the Self a combination of "me" and "I", i.e. me as an object in other people's eyes will have impact on how I see myself. Mead was more concerned with the process of individual identity formation, nevertheless his interactionist perspective can be equally applied to national identity formation. That is to say, the formation of self-image of a certain nation requires other nations to serve as a "looking glass". Positive identity, as Wendt points out, cannot be conferred only by the "in-group" but also by a broader spectrum of "out-groups" (1992: 397-98). ${ }^{3}$ Hence how a nation views itself is greatly contingent on how it is seen and treated by Others.

While most scholars agree that there must be Other in the process of Self identification, their views differ with regard to the relationship mode between Self and Other. Against the view that collective attachments are always affirmed in antagonistic opposition to Others, Wendt argues that the Other need not be contrasted

\footnotetext{
1 Chantal. Mouffe, The Democratic Paradox. London: Verso, 2000.

2 G. H. Mead, Mind, Self and Society. Chicago: University of Chicago Press, 1934.

3 Alexander Wendt, "Anarchy is what states make of it: the social construction of power politics", International Organization, 46(2): 391- 425, 1992.
} 
in such a stark, contrasting fashion and it is quite susceptible to change (1999: 305). ${ }^{1}$

Scholars like Wendt see both positive and negative factors such as love, admiration, competition, resentment, hostility, etc. as potentially effective in the formation of Self-Other relations. This is proven by the fact that there do exist 'positive Others', which a group would desire to identify with rather than differentiate from (Neumann \& Welsh, 1991: 331). ${ }^{2}$ Therefore, Self interacts with multiple 'Others' and construct various Self-identities and Self-Other relations. Which Self identity and which Other should be salient largely depends on the political context of a particular moment. "One should not rule out the possibility of turning a traditionally opposite Other into a positive Other, with which one could have mutually fruitful interaction" (ibid).

The interactional relationship between Self and Other can be captured from the way how the Other is imagined. The images of the Other comprise a series of features that are related to each other in meaningful ways. According to Herrmann et al, how these features cluster and cohere is determined by three factors: the perceived relative capability of the actor, the perceived threat and/or opportunity represented by that actor, and the perceived culture of that actor (1997: 408). ${ }^{3}$ In other words, strength/weakness, friendliness/hostility and cultural commonality/cultural difference are the major blocks for building the image of the Other and the Self-Other relations.

Unlike other identities, national identity is inevitably linked to national political purpose, which encompasses values and principles. It involves the idea of what political and economic system should be adopted for the nation and whether this system is universally appropriate. More importantly, it reflects the interests of a nation and keeps its actions in line with its pursuit of proper status in the international

\footnotetext{
1 Alexander Wendt, Social Theory of International Politics. Cambridge: Cambridge University Press, 1999.

${ }^{2}$ Iver B. Neumann \& Jennifer M Welsh, "The Other in European Self-Definition: An Addendum to the Literature on International Society”, Review of International Studies, Vol. 17, No. 4, pp. 327- 48, 1991.

${ }^{3}$ R. K. Herrmann, J. F. Voss, et al. "Images in International Relations: An Experimental Test of Cognitive Schemata", International Studies Quarterly, Vol. 41, pp. 403- 433, 1997.
} 
community. This is made clear in Wendt's statement: "identities by themselves do not explain action, since being is not the same thing as wanting, ... Without interests identities have no motivational force, without identities interests have no direction" (2000: 231). ${ }^{1}$ Instead of "political purpose", Wendt uses the word "wanting". What is emphasized here by constructivism is that a nation's identity and interest are interdependent and they together determine the nation's relationship with other nations, i.e. who is its positive Other, who the negative Other, and who the antagonistic Other.

The definition of a nation's identity is closely related to the construing of the Other. In certain cases, category (Eastern or Western, Christian or Islam, European or Asian, etc.) may be construed in such a way as to invoke certain general principles of treating the Other. More directly, however, the definition of a national identity is based on the understanding of impacts the Other would have upon one's national interest, such as the Serbian Other to Albanian nation. What enhances the national interest is to be embraced; what threatens the national interest is to be rejected. One can view the Other positively as well as negatively. All depends on how the national interest and the Other are construed. We should therefore expect those who wish to influence the definition or orientation of their national identity to behave in accordance to their judgment of the Other.

Talking about the Albanian national identity, we need to clarify from the outset what the Albanian nation refers to. Nations can be divided into two types, civic nation and ethnic nation. Civic nations refer to communities of participating citizens, whereas ethnic nations refer to communities bound together by blood, common language, culture and history. The Albanian nation, ever since its rebirth in the $19^{\text {th }}$

\footnotetext{
${ }^{1}$ Alexander Wendt, Social Theory of International Politics. Cambridge: Cambridge University Press, 2000.
} 
century belongs to the latter type, i.e. it includes all Illyrian descendents speaking Albanian language. Commenting on the models of nation in Europe, A. Smith points out that the Western model arose out of the Western absolutist states whereas the Eastern model emerged out of the situation of incorporated ethnic communities, whose intelligentsias sought to liberate them from the shackles of various empires (61). ${ }^{1}$ Therefore, while the Western model focused on the building of centrality of national territory, a common system of laws and institutions, the equality of citizens, etc., the Eastern model was preoccupied with ethnic descent and cultural ties. This was the case with the Balkan nations back in the $19^{\text {th }}$ century, including the Albanian nation. The Albanian nationalist pioneers devoted themselves to the establishment of literary Albanian language, the awakening of national consciousness, the creation of myths of the Albanian national hero Scanderbeg, etc. The decisive event in the period of Albanian National Rebirth was the formation of the League of Prizren ${ }^{2}$ in 1878 , because, as the Albanian scholar Sulstarova writes, “The three years of [the League's] existence functioned as a basis for the formation of Albanian nationalist legitimacy as well as for formulating the Albanians' political requests". ${ }^{3}$ Though the political program of the League of Prizren was not realized, it set framework for Albanian nationalist dream. For Albanians, their nation was unfairly amputated at the London Conference in 1913. ${ }^{4}$ In Albanian people's mind, nation is an ethnic concept. The debate mentioned above between Kadare and Qosja on the Albanian national identity

\footnotetext{
1 Anthony D. Smith. "National Identity and the Idea of European Unity," International Affairs, Vol. 68, No. 1 (Jan., 1992), pp. 55-76.

2 After the Russo-Turkish war of 1877-1878, the Treaty of San Stefano was imposed on the defeated Turks whereby they were forced to concede large portions of areas populated by Albanians to the Balkan Slavic states, Bulgaria and Serbia. In June 1878, the leaders of the Albanian nationalist movement gathered in the Kosovo town of Prizren and created the Prizren League, whose primary purpose was to organize political and military opposition to the dismemberment of Albanian-inhabited territory and unite the four Albanian vilayets, namely Shkodra, Kosova, Manastir and Janina, into one nation state.

${ }^{3}$ Enis Sulstarova, Ligjërimi Nacionalist në Shqipëri: Rilindja Kombëtare, Komunizmi Dhe Paskomunizmi. Tirana: Afërdita, 2003.

${ }^{4}$ In 1913, the London Conference recognized the newly declared Albania state, but confined it within the present border, while leaving half of the Albanian population and the lands outside, including Kosovo, the Western Macedonia and the northern Greece.
} 
covers not only the Albanians in Albania proper, but also those in Kosovo, the Western Macedonia and so on. ${ }^{1}$ Thus, in this dissertation, the Albanian nation employs the definition in terms of ethnicity.

The second reason why I call this study a case in point is that it reflects the close relationship between literature and politics with regards to the construction of national identity. If national identity is at least partly defined in terms of their culture, then literature as an important part of culture has a significant role to play. Countries often take particular writers or poets to play the key role in shaping national identity. For example, Shakespeare in England, Moliere in France, Goethe in Germany, Pushkin in Russia contributed to the formation of their national identities. ${ }^{2}$ George Orwell's novel Nineteen Eighty Four also testifies to the great political effect a literary work can have. Talking about Orwell's Nineteen Eighty Four, Horton points out that novel is "a much more appropriate vehicle than the political pamphlet or theoretical treatise" because it is less abstract in content and less authoritarian in its relationship with the reader (24). ${ }^{3}$ As observed by Benedict Anderson, "Fiction seeps quietly and continuously into reality creating that remarkable confidence of community in anonymity, which is the hallmark of modern nations" (2006: 36). ${ }^{4}$ Indeed, from $18^{\text {th }}$ century romanticism to $21^{\text {st }}$ century postmodernism, writers have played a crucial role in shaping and maintaining national identity. Noting that writers have been the

\footnotetext{
1 There are approximately 7 million Albanians in the world, mainly within the Albanian Republic (around 3.6 million), in Kosovo (roughly 1.9 million), in Macedonia (0.5 million), and in the Albanian diasporas in Italy, the USA, etc. Data from the World Factbook (2009) provided by Central Intelligence Agency (CIA) on https://www.cia.gov/library/publications/the-world-factbook/geos/al.html

${ }^{2}$ Shakespeare, Moliere, Goethe and Pushkin did not write as much as Kadare does about political dynamics. Nevertheless, they were inevitably involved in politics. That is to say, the most important value of their works is that they reflect the ideology, the political background and the zeitgeist of their time. They are regarded as the greatest writers/poets of their nations due to their crucial roles in the standardization of their national languages, in the promotion of the zeitgeist of their time, as well as in reflecting the cultures and spirits of their nations. From this perspective, they can serve to qualify the above mentioned A. Smith's remarks regarding the difference between the Western model and the Eastern model nationalisms.

3 John Horton, "Life, Literature and Ethical Theory: Martha Nussbaum on the Role of Literary Imagination in Ethical Thought", Literature and the Political Imagination. Ed. Horton, John and Andrea T. Baumeister, New York: Routledge, 1996.

${ }^{4}$ Benedict Anderson, Imagined Communities. London: Verso, 2006.
} 
persistent collaborators of historians in popularizing specific view and creating popular historiography, Said stresses that "The intellectual's role is first to present alternative narratives and other perspectives on history than those provided by the combatants on behalf of official memory and national identity - who tend to work in terms of falsified unities, the manipulation of demonized or distorted representations of undesirable and/or excluded populations, and the propagation of heroic anthems sung in order to sweep all before them" (2008:37). ${ }^{1}$

As can be seen, writers have been duly acknowledged as a special category of intellectuals who occupy a prominent role in the scholarly work devoted to the construction and reconstruction of national identity. In the meantime, they are also expected to present responsible narratives and perspectives on history and national identity. They should "construct fields of coexistence rather than fields of battle as the outcome of intellectual labor" (ibid).

Kadare has been fully engaged in the Albanian national identity construction and reconstruction ever since 1960s. His craft of writing is indisputably superb. Unfortunately, the outcome of his labor is more of the nature of battlefield than coexistence field. Presenting the Other is the most prominent characteristic of his writing style. As mentioned previously, some identity theorists hold that there are positive Other and negative Other, and they are susceptible to change to the opposite under certain circumstances. The negative Others in Kadare's works and the change of Western Other into European Mother are good sources and the right case to illustrate the relationship between writers and politics, as well as the factors that determine a writer's choice of what to present for the purpose of (re)constructing his national identity.

\footnotetext{
${ }^{1}$ Edward Said, "The Public Role of Writers and Intellectuals", pp. 19-39, in Helen Small (ed.) The Public Intellectual. New York: John Wiley \& Sons, 2008.
} 
This dissertation focuses on the Others that appear in Kadare's works. Through a careful examination of his works, I have found four Others of the Albanian nation: the Western Other, the Oriental Other, the Internal Other, and the Neighboring Other. These four Others will be dealt with respectively in Chapter Two through Chapter Five. Each chapter will be divided into three parts, the political background, the specific Other presented in Kadare's works, and a subsequent discussion. Chapter Six, named "From Other to Mother", will look into Kadare's arguments on Albanian nation's pure European identity and the nature of the re-found European Mother.

The final chapter named "Transcending the Otherness Empathically" will sum up the research findings of this study. As the subtitle of the dissertation suggests, the main point of the study is the construction of Albanian national identity. Summary statement will be given in terms of how the four national Others have been constructed in service to the formation of the Albanian national Self and why the Western Other has been rhetorically called "Mother". It will point out the political nature and fluidity feature of the in-between nations like Albania. In this section, the non-dichotomist side of Kadare and his humanistic vision as reflected in his literary fictions will be examined as a balance to the criticism of Kadare's dichotomist mentality in treating his personal and the Albanian national identities. The dissertation will conclude by calling for efforts from intellectuals like Kadare to build humanistic platforms on which nations can be oriented to transcend the limitations of political Othering. 


\section{CHAPTER 2 THE WESTERN OTHER}

\subsection{Background}

After the Second World War, Albania under the new ommunist regime was facing serious economic, social and political problems. It was under severe control of Yugoslavia, which attempted to incorporate the little neighboring country into the Yugoslavian Federation. Both the Soviet Union and the USA considered Albania a satellite country of Yugoslavia and were careful not to lose influence in Tito's Yugoslavia because of Albania. The Soviet Union recognized the People's Republic of Albania in 1945, but it did not show earnest interest in and support for Albania until Stalin got angry with Tito for the latter's disobedience. The USA, out of its geopolitical interest in the Balkans, didn't even agree to establish diplomatic relations with Albania, using Hoxha regime's refusal of recognizing the prewar bilateral treaties and agreements as alibi. ${ }^{1}$ As noted by Ranko Petkovic, the Western attitude toward Albania after WWII, especially their lack of interest in inviting Albania to attend the Paris Conference in 1946, led to the anti-Western philosophy in Albania $(269-270) .^{2}$ Therefore, in the first few years after its liberation, Albania found itself in a hard situation to get recognized by the international community and to become part of the post-WWII international system, such as joining the United Nations and other

\footnotetext{
1 The US refused to establish diplomatic relations with Hoxha's regime after Albania's liberation in 1946. The stated reason is that the Albanian government did not agree to recognize the validity of the prewar treaties of arbitration, conciliation, naturalization and extradition. There should be other true reason behind the refusal because there were no substantial issues in the prewar treaties. For the content of the treaties please refer to United States Department of State / Foreign relations of the United States, 1946. Eastern Europe, the Soviet Union (1946), Albania, page 26.

${ }^{2}$ Ranko Petkovic, "Yugoslavia and Albania", in Yugoslav-Albanian relations. Trans. Zvonko Petrnički, Darinka Petković;. Belgrade: Review of International Affairs, 1984.
} 
international institutions.

The Stalin-Tito split in 1948 not only saved Hoxha from Tito's grip, but also gave Albania a better opportunity for economic development and world recognition. In 1955, Albania became a UN member state. However, as a counter effect, the alliance with the Soviet Union pushed Albania forward to the frontier of confrontation against the West, especially against the US. A top US State Department document, dated Sept. 1949, reveals that its urgent objective toward Albania was the "weakening and the eventual elimination of the Soviet-dominated Hoxha regime," ${ }^{1}$ which is in accordance with the conclusion reached at the meeting held in April 1949 under George Kennan: "setting up of a new regime which would be anti-communist and therefore pro-Western". 2 Both the US and Britain were inclined to support the Greek claim for sovereign right over Northern Epirus, i.e. the Albanian southern territories. On July 29, 1946, the US senate passed a resolution supporting Greek claim to southern Albania, though the US government did not officially adopt this position. ${ }^{3}$

Albania was in conflict with Britain as well due to the Corfu Channel mining incident of October 1946. In late 1945, the British Navy began clearing mines in the channel between Corfu Island and Albania, which was protested by Albania as a territorial violation. Britain argued that the Corfu Channel was an international waterway and ignored Albania's claim of sovereignty over waters extending three miles from its coast. On May 15, 1946, Albanians fired on British ships that entered its claimed water area, and when British Navy sent four destroyers to the Channel, two of them were hit by mines, killing forty-four and injuring forty-two sailors. The incident was later taken to the International Court of Justice but the Albanian

\footnotetext{
${ }^{1}$ Foreign Relations of the United States 1949, v. 5: Eastern Europe; the Soviet Union, Washington: Government Printing Office, 1976:321.

${ }^{2}$ Ibid. 12-13.

${ }^{3}$ US Congressional Record, 79 Congress, $2^{\text {nd }}$ session, 1946, part 8, p. 10336.
} 
government denied any responsibility and refused to pay the fine imposed by the Court. ${ }^{1}$ Between 1949 and 1954, various groups of commandos, comprised of Albanian émigrés in the West, were sent to Albania by air, sea or land with the aim of organizing anti-communist forces to overthrow the regime. The Anglo-American subversive operations against the Albanian communist regime, though failed, deepened the enmity between Albania and the West. As a result, Enver Hoxha was highly suspicious against the US-led West, perceiving the Western Other as the major enemy from outside.

Albania's breakup with the Soviet Union in the early 1960s and its deterioration of relations with China in the 1970s were characterized with Albania's loud voice against revisionism and against the reconciliation of socialist camp with the capitalist world, especially the imperialist US. On the surface, it appears to be the outcome of ideological divergence, but in fact, the real important reason is that the reconciliation of Soviet Union or China with the US was perceived by Hoxha as a huge threat to his regime. Therefore, when the US sent friendly signals to Albania after Albania's break with the Soviet Union and later with China, ${ }^{2}$ the US offers for normalization of bilateral relations and establishment of diplomatic relations were rejected. Hoxha's hostility toward the US and the capitalist world continued. In 1976, to highlight its ideological stand, Albania passed a new constitution which changed its official name from People's Republic of Albania to People's Socialist Republic of Albania. As a result of the fear that economic dependence would result in the loss of political independence, the constitution also prohibited loans or investments from the West. Hoxha's writings and the Albanian newspapers during his rule were replete with

\footnotetext{
${ }^{1}$ Miranda Vickers, The Albanians: A Modern History, 169-170. London \& New York: IB Tauris \& Co 1999.

2 Adjusting its foreign policy with Albania, the US claimed that "the obligations contained in the pre-war US-Albanian bilateral agreements would appear no longer to possess substantial intrinsic importance." See William Bland and Ian Price. A Tangled Web: A History of Anglo-American Relations with Albania, London: The Albanian Society, 1986, p. 296.
} 
hostility toward the West, especially in political and cultural spheres:

The U.S. imperialists and the Soviet social imperialists ... are now the main and equally dangerous enemies of the freedom and national independence of the peoples of the world. Despite their deep contradictions and the wolflike struggle with each other to obtain stronger dominating political and economic positions in the world, they still try in every way to reach agreement and act together in dividing the spheres of domination and influence. (Quoted in Biberaj, 206) ${ }^{1}$

Why should we turn our country into an inn with doors flung open to pigs and sows, [...] to the hirsute, longhaired hippies to supplant, with their wild orgies, the graceful dances of our people? (Quoted in Vickers 1995:101)²

Kadare also contributed to the anti-West propaganda. For example, in his work

The Wedding, he expressed contempt for the American rich life.

What can Rockefeller boast of more than I? On the contrary, he has much less. If Rockefeller had this wedding party today in his palatial halls, he could pour out bagfuls of dollars, he could have all the drinks and eatables and music, as much sincere affection as is gathered here, in this barracks, tonight. He could not purchase all this love for all his gold. $(118)^{3}$

Also in 1971, when Kadare was visiting the US, he wrote,

After wealth the bourgeois seeks for power and after power they seek glory. One century ago Marx had foreseen this as well... The morbid American society demonstrates itself especially at night... Broadway is a kind of exhibition of New York. Here luxury and misery, beauty and shame, brutality and protests, wisdom and degeneration, stay side by side, appallingly exposed to light. When night falls, Broadway is stripped naked and shows all its vulgarity, greedy, shameless ... On Broadway, against the background of blinding light, misery and degeneration are shown naked. The USA has become a classic place for political blackmails and murders. Here assassination preparation has reached its highest perfection ... Liberty Statue

\footnotetext{
${ }^{1}$ Quoted in Elez Biberaj's Ph.D. dissertation: Albania and China: 1962-1978, a Case Study of a Bilateral Unequal Alliance, 1985, Columbia University. Bashkimi, March 21, 1974.

${ }^{2}$ Miranda Vickers, The Albanians: A Modern History. London: Tauris, 1995.

${ }^{3}$ Ismail Kadare, The Wedding. Trans. Ali Cungu. Tirana: Naim Frashëri, 1968.
} 
is a monument that the bourgeois raised for its own freedom to rule $\ldots(279,283,289)^{1}$

This chapter examines two of Kadare's works of the 1960s and 1970s in which the Albanian anti-Western political stand was most artfully reflected by Kadare, namely General of the Dead Army (1963) and Doruntine (1979). I will show through textual analysis how in these novels the West is depicted as a hostile and immoral Other, which has done too much harm to the Albanian nation over the history and still poses threat to the independence and sovereignty of the Albanian nation.

\subsection{The Hostile Other}

Hostility is a negative evaluation of other people, often accompanied by a clear desire to do harm them (Kaufmann 1970). ${ }^{2}$ According to George Kelly, hostility can be defined "in the language of nations - we all know how clearly everything the enemy does expresses his cruel and vicious nature (276). ${ }^{3}$ In other words, if a nation perceives hostility against another, then the latter is presented as an evil enemy.

For many years, the world kept hearing about the conflicts between hostile nations in the Middle East, in the Balkans, etc. Numerous lives have been claimed as a result of the hostility; and in turn, new deaths bring greater hostility. Consequently, being caught in a vicious circle, death and hostility give rise to each other, causing endless conflicts.

\footnotetext{
${ }^{1}$ Ismail Kadare, “A world in the fall” (Një botë në rënie) in Literary Works (Vepra Letrare), volume 12, 271-294, published by Naim Frashëri in Tirana in 1981. The original text is: Pas pasurisë borgjezia kërkon pushtet dhe pas pushtetit kërkon lavdi. Një shekull më parë Marksi e ka parashikuar edhe këtë. ...Shoqëria e sëmurë amerikane e tregon veten e saj sidomos natën... Broduej është një lloj ekspozite e Nju Jorkut. Këtu lluksi dhe mizerja, bukuria dhe turpi, brutaliteti dhe protesta, mençuria dhe degjenerimi, të ndriçuara në mënyrë të ethshme, rrinë pranë e pranë... Kur bie nata, Broduej shfaqet lakuriq me gjithë vulgaritetin e vet, i babëzitur, i paturpshëm... Në Broduej, në sfondin e shkëlqimit të çmendur, mjerimi dhe degjenerimi shfaqen lakuriq. ...SHBA janë bërë vendi klasik i shantazheve dhe vrasjeve politike. Përgatitja e atentateve ka arritur këtu përfeksionimin më të lartë... Statuja e lirisë është monumenti që borgjezia i ka ngritur lirisë së saj, lirisë për të sunduar. ..."

${ }^{2}$ H. Kaufmann, Aggression and Altruism: A Psychological Analysis. New York: Holt, Rinehart and Winston, 1970.

${ }^{3}$ George Kelly, Clinical Psychology and Personality: The selected papers of George Kelly, New York: Wiley, 1969.
} 
Death has been treated by Kadare in many of his works, such as Doruntine, Broken April, Three-Arched Bridge, General of the Dead Army, etc. Some people die a glorious death, like the death of Doruntine's brothers who fought to defend their country. Some die a death imposed social norms, like the death of Gjorg, who had to kill in order to avenge his brother and protect his family's honor. Some die as a sacrifice to usher in a new world order, like the immurement of Murrash Zenebisha inside the bridge so that the construction will stay. There are also others who die a sublime death, like Gjoleka in The General of the Dead Army, who did not die on the battles against fascist invasion, but died as a result of infection when he was performing the humanitarian work of digging out the remains of the dead soldiers left by the invading army. Death, as Kadare shows to us, can be of various natures, but behind the veil of death lies the truth about social norms, the struggle for interests, justice and injustice, the relationship between nations, and so on.

The General of the Dead Army, as the title itself suggests, deals predominantly with the theme of death. Though many other interpretations can be given with regard to the general's mission of collecting the remains of the Italian soldiers who perished during the Second World War, it is obvious the novel reveals the consequences of death and killing. Whereas the other Albanian writers such as Fatmir Gjata, Dritëro Agolli ${ }^{1}$ etc. treated the Albanian Anti-Fascist National Liberation War while depicting directly the partisans' heroism and patriotism, Kadare wrote about the war from a unique perspective, from the tragic legacy perceived by the Italian general and priest twenty years after the war when they were assigned to collect the Italian dead soldiers' remains. A sinister and hostile atmosphere permeates the whole book. The West, represented by the arrogant general and evil priest, is presented as a hostile

\footnotetext{
${ }^{1}$ The Albanian films such as Furtuna (The Storm, 1959) and The Bronze Bust (I teti në bronz, 1970) based respectively on Fatmir Gjata's script and Dritëro Agolli's novel Komisar Memo (Kommissar Memo) were among the most popular films in China during the 1960s and 1970s.
} 
Other, the Other from across the sea which invaded Albania but never repented for their crimes against the Albanian nation.

The novel tells the story of an Italian general who travelled to Albania in the 1960s to carry out his mission of exhuming and repatriating the remains of Italian fascist soldiers killed in the Second World War. The general was accompanied by a priest, who knew the Albanian language and had a pretty negative view of the Albanian nation. Before leaving for Albania, many of the families of the dead soldiers went to meet with the General and the priest, pleading with them to bring back the bodies of their beloved sons. The biggest pressure, though, came from an aristocratic family, whose son/husband served as a colonel during the war and disappeared mysteriously on the Albanian land.

The novel follows the general as he searched all over Albania for a whole year for the remains of the soldiers, matching them with the data on his name list, such as height, dental information, etc. He embarked on his mission with self-importance, taking it as an honor. However, his pride and enthusiasm decreased as he was confronted by the sinister surroundings as well as the stories of the Italian soldiers and officers during the war, revealed by a café-owner, a peasant, an old woman, the dead Italian soldiers' diaries, etc.

The General had an Albanian expert and a group of workers assigned to him by the Albanian government to help with his task. They performed grueling labor of consulting villagers to locate the dead bodies, digging them up, bagging them in nylon sacks, sorting and identifying them with the names on the General's lists of the dead. His companion, the taciturn priest, who was alluded to have an affair with the widow of the mysteriously missing Colonel Z., kept warning the general of the Albanian nation's revenge tradition and the menace they were facing in completing 
their mission.

The priest's warning proved to be true. When their work was concluding, the general still had no clue where Colonel Z.'s body might have been buried. In the village where the colonel was said to have disappeared, they tried in vain to find any useful information. Depressed and tired, the general heard the music of a wedding party in the village and decided to relax for a while. Ignoring the priest's protest, the general went to the wedding where he was kindly received by the host. He never imagined that it would be there that he finally found the bones of Colonel Z. An old woman named Nice was also at the wedding. She could not hold back her anger when she saw the Italian general come to the wedding in a manner as if nothing had happened twenty years ago. All of a sudden, she burst into wail, when the general stood up to join the dance. Nice ran out in the heavy rain and came back to the wedding party with a sack on her back. She threw the sack in front of the general, telling him that it was the cursed bones of the Colonel Z. She killed him because the colonel not only took her husband's life but also raped her daughter who afterwards committed suicide. For twenty years, Nice kept the body of the colonel buried under her doorstep and the hatred deep in her heart. The story of Colonel Z. brings the novel to its climax. It totally broke down the general's pride and sense of superiority. He felt ashamed and saw the body of the Colonel as an ominous symbol. On his way back to Tirana, the general "accidentally" kicked the sack of the colonel's bones into the river, which was immediately carried away by the turbulent current. The accident was not acceptable to the priest, for he understood that it was a subconscious act of the general.

In the final section of the novel, the general was drinking in a hotel with his German counterpart, who was performing the same duty for their dead. The German 
lieutenant-general offered to sell the Italian general one of their dead soldiers who had the same height as Colonel Z., so that he could have rapprochement with the priest and make his mission "accomplished". Deadly drunk, the general went to the priest's room, suggesting that they replace Colonel Z. with the bones of the soldier who had the same height as the colonel. He even offered his own body for replacement, which was ironically the same height.

The West is otherized in The General of the Dead Army, in contrast to the heroic and humanitarian Self of the Albanian nation who, despite the sufferings and bitter memory of the war, agreed to provide assistance in repatriating the Italian fascist soldiers' remains. The heroism and humanitarianism of the Albanian people were epitomized by the old partisan Gjoleka, who fought bravely for his country's liberation but lost his life in the process of digging up the bones of fascist soldiers. The aggressive, hypocritical and immoral nature of the West and the hostile stand of the West toward Albania are exposed through the Italian government's behavior and the psychology of the people representing different social strata, particularly the general and the priest.

First, let's look at the Western aggressiveness. The fact that fascists invaded other countries is not regarded by the Italian government as immoral. On the contrary, those who fought for the country for the purpose of territory expansion were considered national heroes. Colonel Z. for example, was glorified by

The sumptuous marble tomb erected for the colonel with its stature and those beds planted with red and white roses all around, even though it is empty. (20) ${ }^{1}$

The Colonel's mother was so sad about her only son and tried all means to find

\footnotetext{
${ }^{1}$ This text analysis in this dissertation is based on both the Albanian version and English version of Kadare's works. I quote from the English version after I confirm with the Albanian version. I use my own translation only in case there is no English version of Kadare's works. The quotes from The General of the Dead Army are all from the English version published by the Arcade Publishing, New York, 2008.
} 
her son's remains. Her efforts went in vain, and her psychological pains increased with each passing year. Nevertheless, she didn't complain about the fascist invasion which inflicted numerous deaths, including the loss of her son. Instead, she kept talking proudly about her son's glorious sacrifice to the country:

He had every virtue! Everyone thought he had the makings of a military genius. Those were the words when the Minister of War came to offer us his condolences, he said that "it is a great loss, a very cruel loss for us all" She regretted that her son stayed only for a very short time for his wedding because "his duties were so important he couldn't stay away from that accursed country any longer." (82)

Twenty years after the defeat of the fascist war, the Italian nationalist passions were still high. This can be clearly seen from how the general felt after he took the mission.
After the general took the mission, he felt solemn and funeral music echoing in his heart. When he opened the files, he felt that those interminable lists were breathing out great gusts of vengeance. When he saw the small dot of Albania on the globe, the hatred flood through him again: this pinprick on the map had filled the mouths of his country's brave, beautiful children with dust. He felt he wanted to get to this savage, backward country (as the geography text books all called it) as soon as he possibly could. He wanted to walk proudly among these people that he envisaged as a wild barbarian tribe, looking down at them with hatred and contempt as if to say: "Savages, look what you've done!" (139)

As can be seen, by only a few words in the parentheses, Kadare reveals how the Italian state machinery uses school education as a way of mass propaganda to portray Albania as an inferior Other that needs to be conquered and civilized. In other words, the post-war Italian official media still justify the fascist invasion as a noble mission to eradicate barbarity and backwardness. The colonial complex is still prevailing in the post-war Italian society. Therefore, for the general and the numerous people who lost their dearest on the Albanian battleground, it's not the fascist invasion that should 
be condemned, but Albanian people's stubborn determination to defend their country from foreign occupation. The passage indicates the pathological effects of colonialism ideology and the doctrine of cultural hierarchy and supremacy on the West represented by Italy. In the general's eyes, the heroic resistance of the Albanians was incomprehensible savageness that should be hated and denounced.

These Albanians, you would never believe that in battle they would turn into wild beasts. (23)

This attitude toward the fascist invasion of Albania and their hostility toward the Albanian people were clearly shown also from the words of an ex-general who took part in the Albanian campaign. He went to meet the general before the latter set out on his mission, with the purpose to warn his peacetime colleague of the wickedness of the Albanian people.

I have nothing more to say. I simply wanted to warn you. Be always on your guard. Keep your head high, and never let them see you bow it. They will try to provoke you, they may try to make a fool of you, and you must know how to answer them. You must be on the alert all the time. They will try to insult our soldiers' remains. I know them too well. They often jeered at us. They didn't give a damn even then! Imagine what they will be capable of now! (38)

The general never came to realize that the true reason for the fascist army's defeat was that they launched an unjust war. Therefore he held a strong hostile attitude toward the Albanian government and people.

$[\mathrm{He}]$ protested when he saw on the wall bounding a cemetery the words "Such is the fate of our enemies", claiming that it is a shameful provocation incited by the Albanian government. (48-49)

He blamed the Italian military defeat on the incompetence of the generals of that time. He blatantly expressed his contempt when the ex-general came to visit him. $\mathrm{He}$ 
was confident that if he had been the leading general for the war in Albania, their army would not have suffered such a tragedy. The private arrogant psychology of the general was detected by the priest:

The reason you are suffering from this sense of oppression is that in the depths of your soul you regret not having led our divisions in Albania yourself. And you tell yourself that under your leadership everything might perhaps have gone differently, that instead of leading our troops to defeat and destruction you would have ensured that they emerged with honor from that great test. That is why you are constantly spreading out those maps of yours, hunching over them for hours on end, scribbling battle plans on your cigarette packets. You lament over every failure, you relive every setback as though they were realities, and you see yourself retrospectively in the place of those ill-starred officers who commanded our troops then; and you have begun to entertain an utterly irrational dream: that of transforming our defeats into victories ... (138-139, italic emphasis mine)

All these are the manifestations of the Western aggressive mentality. The general epitomizes the Western Leviathan spirit, the evil desire to conquer and subdue weaker nations. The general's constant spreading of maps and his scribbling of battle plans refer to the West's systematic planning of the military conquest ever since the Roman Empire. There is no slight sign that the general repented for their killing of the local people. On the contrary, he hates the people who rose up to protect themselves. What he regrets is that they didn't win the war. The priest's burrowing into the general's inner secrets is tantamount to an analysis of the Western pathology of colonialism. Such a mentality points to the potential threat the West poses to weaker nations like Albania. If they were given a chance to reoccupy Albania, they would grab it with no hesitation. The aggressive, hostile and dangerous Western Other is thus constructed, calling for Albanian people's vigilance.

Actually, as the novel further shows, in Albanian people's mind ever since the ancient times, the West has always been conceived as a monster from the sea. The 
Roman conquest and other Western invasions inflicted on the Albanians over the history have made fighting against the West an instinctive reaction and a glorious tradition. In the novel, the author invokes the Albanian legendary figure Gjergj Elez Alia as proof for the tradition.

The general had been told how news had spread through all the regions of the country, and how from all its four corners men set out in groups of five, or ten, or twenty, guns over their shoulders, on their way to fight. They came from considerable distances, without anyone having organized them, crossing mountains and valleys, with a hint of something ancient in their progress, something very ancient that had perhaps been handed on to them like an instinct, from generation to generation, since the legendary times of Gjergj Elez Alija, when evil, like a monster, always emerged from the sea, and had to be exterminated on the very seashore itself if it was to be prevented from insinuating itself inland. It was a very old sensation of alarm that had awakened in them, an ancient apprehension aroused by the sight of blue waters ..." (156)

Many of them were not even concerned to know what country it was now assailing them, or that enemy they were going to fight, since that was a matter of little importance to them. The important thing was that the evil was rising once again from the sea and must be driven back into it. Many had never seen the sea before in their lives, and when the Adriatic appeared before them they must no doubt have cried: Ah, but how beautiful it is!" And they could no longer believe it possible that this was the source of the evil. But then they looked out with indifference at the teeming war ships standing off the shore, at the gigantic gun barrels trained on the coast, at the skimming planes, at the landing barges, and without further ado they began the fight, as tradition prescribed. (157)

As can be seen from above, the author aims to impress the readers with what has happened in the history of the human race between the West and Albania, and what is the subsequent consequence of the war launched by the West due to their insatiable greed for wealth and territory expansion. Aggressiveness is depicted as an intrinsic part of the Western identity. The Albanian nation, on the contrary, has developed their hate for foreign invaders and their heroic spirit in the course of fighting for independence and freedom. 
The mutual hostility between the Albanians and the Western invaders is more than clearly represented in the words of the Albanian expert and the old woman Nice on the one hand, and the priest and the general on the other.

"Twenty years ago you scrawled your Fascist slogans on our comrades' chests before you hanged them, and now you pretend to be appalled by a few simple words like that, probably put there by a schoolchild." said the Albanian expert. (48-49)

You are a foreigner and you belong to one of those armies that killed my family. To judge by your insignia, invading people is your trade and you are one of those who broke my life, who turned me into the unhappy old woman I am, and old woman who has come to a wedding feast that is nothing to do with her and sits in a corner mumbling like this. ... I am staying here in my corner cursing you between my teeth, quietly ..." (198)

The priest said, “... at moments like this singing is a spiritual need for these men. Can you conceive of any greater satisfaction for an old soldier than that of pulling his enemies back up out of their graves? It is like a sort of extension of the war." (88)

The general broke in, "Have you noticed how much we talk about them (the Albanians)? After all, what do we really care about their affairs? All we ask is that they should exterminate themselves. And the quicker the better." (137)

Even on occasions which are supposed to be dominated by polite and friendly

atmosphere, the hostility can be explicitly perceived:

He (the general) had thanked the Albanian authorities, on behalf of his people and the thousands of mothers concerned, for all the facilities that had been made available to them in their search. The Albanian side replied by saying that they had done no more than fulfill a humanitarian duty towards another people with whom it was Albania's wish to live in peace. They had all touched glasses and drunk a toast - and beneath the crystalline tinkling of the glasses it was as though as distant rumble of guns could be heard. No one can get rid of it, that muffled thunder, the general had thought to himself, and all of them here are aware of it, even though they refuse to admit it. (239, italic emphasis mine)

Aware of the crimes they had committed to the Albanians, the general was highly sensitive and alert to the hostility of the local people. Talking about the old man in his 
grave-digging group who participated in the anti-fascist war, he said,

I can see hatred in his eyes. ... We are mortal enemies, yoked together to the same task, like a pair of oxen. One black, the other no less so. The joy of the one made the grief of the other.

He felt humiliated when an Albanian peasant told him that an Italian soldier, who was finally killed by the fascist punitive unit Blue Battalion, had worked for him for a year and he, out of humanitarian duty, would like to see the remains of poor soldier return to his own land. As a way to keep his dignity, the general "walked very slowly toward the peasant, wearing a grave expression. It was the attitude he always adopted when in the presence of the Albanian peasants" (95). At the wedding to which he went with no invitation, the general "could feel the glances of the people around him falling on him like silent arrows" (199), even though the head of the house received him politely according to the old Albanian traditions. He felt that the local people regarded him as an evil intruder. For a whole year, the general was tortured by this mutual hostility, the perception of which was exacerbated by the sinister weather and the awful Albanian topographic features.

The priest is an important character in the novel. His remarks about the Albanian nation further show what a hostile view the Western Other holds toward Albanians. While they themselves resort to war from time to time to become more powerful, they defame the Albanians and present it as a war-loving nation.

It's an atavistic instinct that drives them into war. Their nature requires war, cries out for war. In peace, the Albanian becomes sluggish and only half alive, like a snake in winter. It is only when he is fighting that his vitality is at full stretch. (28)

Deprived of war and weapons this people would wither away, its roots would dry up and it would eventually just disappear... with weapons or without, they are a people doomed to annihilation. (133) 
No wonder the Albanian expert had to refute the priest's point of view, disclosing their real purpose under the cloak of psychological studies.

There are certain foreigners who come here and study our vendetta with what appears to be enormous enthusiasm, but they do so with a predetermined intention. Their real aim is to spread the notion that the Albanian people is doomed to annihilation to make people familiar with it and accept it. (136)

Other characters in the novel also function as bricks for the construction of the Western hostile Other. While the general and the priest are un-named, some minor characters have carefully designed names. Different interpretations have been given in terms of the meanings carried by the names. Erica Weitzman, for example, in her paper "Specters of Narrative: Ismail Kadare's The General of the Dead Army" points out that the initial of colonel Z. is read in Albanian as "zë" (meaning "voice") and thus is equivalent to Colonel Voice, "a unitary narrative that would reconcile or erase the competing (living or dead) voices within the novel, that would emerge from the silence of death and of history to bestow meaning upon the general's mission" (296). ${ }^{1}$ While agreeing with Erica's insightful interpretation, I would add that "zë" also means "catch" in Albanian and if the letter Z is read in the American way as [zi:], then it can be interpreted as Colonel of Black Death ("zi" in Albanian means black and is the symbol of death). This is exactly the role of the colonel in the novel. Being the officer of the punitive unit Blue Battalion, Colonel Z. performed the task of punishment. He killed not only the local resistance forces, but also their own soldiers. The soldier who deserted the fascist army was caught and punished with death. And finally he himself ended up with the most humiliating death: killed by the old woman Nicë in revenge for murdering her husband and raping her daughter. In a word, Colonel Z. is cursed to death; he is a hostile and ominous sign. On the other hand, the

\footnotetext{
${ }^{1}$ Erica Weitzman, "Specters of Narrative: Ismail Kadare's The General of the Dead Army". Journal of Narrative Theory 41.2 (Summer 2011): 282-309.
} 
names Nik Martini and Nicë "may be meant as a semi-ironic invocation of Nike, i.e. victory" (Weitzman 293). Nik Martin, who represents the local resistance forces, died heroically and his heroic actions against invaders became the new part of the Albanian epic songs, which will be passed down generation after generation and live in the heart of the Albanian people. Nicë suffered the loss of her husband and daughter, but she killed colonel Z. in revenge. All these characters were part of the war and experienced death and killing, which were caused by hostility and as a result further deepened the hostility.

Finally, it is worth noting the incident of Gjoleka's death. ${ }^{1}$ Gjoleka was first mentioned in the novel when the general and priest heard him singing historical stories to his young fellow workmen. The priest held a hostile attitude toward Gjoleka, because according to his understanding, the old partisan was taking revenge while pulling his war-time enemies out of their graves. A small detail betrays his hostility toward Gjoleka:

"What's the matter with him?" he asked. "He looked perfectly well yesterday afternoon."

"I think it probably is an infection," the priest said. "His face was quite grey yesterday evening." (171)

These are the words the priest said respectively to the Albanian expert and the general. He pretended to be astonished when the expert told them about Gjoleka's severe condition. However, from what he said to the general it is clear that he had already noticed Gjoleka's infection. But he said nothing. When he heard that the doctor had complained "you should have brought him in earlier (175)," he again said nothing. Before Gjoleka died, he stared at the scratch on his hand as though he was

\footnotetext{
${ }^{1}$ Gjoleka is a combination of Gjon/Gjorg (John/George in English) and Leka (short form of Aleksander). It is obviously a Western name. Gjoleka's death can probably be interpreted as Kadare's message to the West that their hostile stand toward Albania has first of all damaged the existence of Catholic religion in Albania. The persecution of religious clergy, the Catholics in particulary, should have been a result of the West's intension of overthrowing the Hoxha regime. In 1967, all the religious institutions were banned and Albania declared itself atheist.
} 
saying: "You killed me ${ }^{1}$, you rotton bastard (175)"! It seems that the fascist soldiers killed during the war took revenge and killed Gjoleka. As the general remarked in surprise, "The germ can stay buried there for twenty years, then suddenly jump out as virulent as ever" (172). But in reality, it is the germ and the priest's hostility together that took Gjoleka's life. In this way, the author warns the Albanians of the Western hostility and threat.

In the novel there is also a German lieutenant-general who was searching for the remains of the Nazi German soldiers. Though the generals come from Italy and Germany, the novel is not confined to the construction of an Italian or German Other in particular but a Western Other in general. It denounces the Western European Other as a whole, the monster from the blue sea which has invaded the Albanian land ever since the ancient times and has repeatedly inflicted war on Albania. The general is aware of the bitter memories the West has left in the Albanian people's heart.

Without this bridge, life in a village so cut off from the rest of the world would just have gone flowing calmly on, and the currents of war would never have reached it. And now, out of the blue, we have appeared and started looking for our soldiers' remains. This stirs up their memories and makes them restless. (169, italic emphasis mine)

Having in mind that blue is the color of Europe, Kadare named the punitive unit under Colonel Z. as Blue Battalion. It is also without purposeful consideration that Kadare described the nylon bags for the dead soldiers as "a pretty blue bag ... with two white stripes across it, black binding around the edges, and the discreet trademark 'Olympia'” (187). As we know, Olympia symbolizes a higher stage of human civilization and peaceful competition, whereas white is the symbol of purity. The design implies that peace and spiritual purity can be achieved only if the Western evil

\footnotetext{
${ }^{1}$ The original words are "Më more në qafë, moj e poshtër". It is translated by Derek Coltman into "You're what did for me, you rotten bastard!", which doesn't make sense. "më more në/më qafë" is an Albanian expression meaning "you damaged me, you put me into serious problems." I translate it into "you killed me" to fit the context.
} 
and hostility can be enclosed and extinguished.

As we can see from above, hostility is the predominant theme of the novel. It exists in the hearts of the general, the priest, the Albanian expert, Nicë, Gjoleka, etc. It is written into the ominous name of Colonel Z. and is put into the Albanian epic songs. War, killing and death have caused hate among people. Gjoleka's death gives out the warning that the war is over but the Western hostility and threat are still there.

\subsection{The Immoral Other}

Naturally, the West is presented in the novel not only as a hostile Other. It also posesses other negative qualities as the Albanian socialist propaganda of that time used to stress. The immoral aspects of the West such as decadence and hypocrisy are also depicted as part of the Western Other. For example, the rape of Nicë's daughter by Colonel Z. which made the general feel very ashamed and totally undid his faith in national glory. Then the general himself, after he accidentally kicked away the colonel's bones, and under high pressure from the priest and the colonel's family, he thought of using the deserter soldier of the same height as Colonel Z. for substitution. The mere thought is as ironic as immoral.

He pictured to himself the reception that the colonel's assembled family would accord to the remains of that simple soldier, the grandiose funeral service, the solemn obsequies. ... Then the poor fellow's bones would be transported to his murderer's magnificent tomb, the bells would ring out, a general would deliver a funeral oration, and the whole thing would be an outrage against nature, the whole thing would be a perversion, a cheat, a profanation. (228)

The priest's decadence was shown through the general's doubt of his love affair with Colonel Z.'s widow:

$\mathrm{He}$ acts as though he is made of metal, that priest. But I'd be 
curious to know, all the same, whether he was as metallic as this when he was alone with Colonel Z.'s beautiful widow. (25)

When the priest said, "I am a man of religion. I cannot approve of homicide" (27) to deny that he found it a condolence to see so many Albanians had been killed as well during the war, the general unveiled his hypocritical lie:

I know perfectly well that you do hate them. Just as I do. But you're right, it's not in our interests to go round saying so just now. (29)

The Western immorality was epitomized also by the German lieutenant-general's pseudo humanitarian work of repatriating their dead soldiers' remains. The Germans did it as a profitable business. They opened "by mistake" the Italian soldiers' graves and sent the remains back to Germany immediately. When the Italian general asked his German counterpart to contact the families who had received the wrong remains, the lieutenant-general replied,

That's easily said, but just think of the consequences. Think what a shock it would be for those families suddenly to be asked to send back the remains! (238)

It would really be catastrophe if the German families found that they paid for the wrong bodies. Moreover, the lieutenant-general even offered to sell one of his own soldiers' bodies to replace that of colonel Z. "as a friend, for a hundred dollars" (258).

If all these examples on personal level are not enough to prove the Western immorality, the author goes further to reveal the immoral behavior of the Westen state. When the Italian government needed to dispatch troops to invade a foreign land, it did not hesitate to cheat the public and give false information.

He could remember it well, that first day of war in the spring of 1939. He had been in Africa then. That evening the news had come over the wireless: the Fascist army, it said, had landed in Albania, and the Albanian people had greeted the glorious divisions bringing them civilization and happiness with peaceful 
waves and even flowers. (150)

Not a day went by without some kind of story appearing in at least one paper or magazine, and at night all the soldiers dreamed of being posted to Albania, to that pretty seaside paradise nestling in the shade of its eternal olive trees. (151)

Then twenty years later, when the country needs the soldiers' bodies to be buried within its own territory in order to repair and rebuild its fragmented national identity, they dug them up, without asking what the dead want. In the Mass ceremony, the priest prayed for the souls of the dead soldiers to rest in peace. The diaries of the soldiers told us that it is futile and hypocritical.

Do you really imagine they'll bother to look for our remains? O.K., so let's suppose they do search one day. Do you think I get any consolation out of that thought? There is nothing more hypocritical, if you ask me, than going around looking for bones when the war's is over. (16)

Immorality, as we can see, is presented in the novel as an important aspect of the Western Other. If in General of the Dead Army the Western immorality has to take the secondary position due to the leitmotif of hostility, then in Doruntine the author found a superb place for an immoral West.

Doruntine is set in the principality of Arbëria, the first Albanian state during the Middle Ages. ${ }^{1}$ The novel is based upon an Albanian legend. At the very beginning of the story there is the sensational news that Doruntine, the only daughter of the Vranaj's family who married a Bohemian man three years ago, has been brought back home by her dead brother Constantine. A dead man rose from the grave only because he had promised his mother that he would bring his sister home whenever she yearns for her daughter's company. This is inconceivable for many people, including the local police officer Captain Stres, who decided to unravel the mystery of Doruntine's

\footnotetext{
${ }^{1}$ The proclamation of Arbëria took place in 1190 in the territory now called Albania, with Kruja as its capital. Progoni is known to be the founder of this state, succeeded by Gjini and Dhimiter.
} 
return. He went to talk with Doruntine and her mother but got nothing really useful. Both of them were dying after the huge shock: Mother was shocked to learn that Constantine brought Doruntine back, and Doruntine was shocked to learn that all her nine brothers died in a plague-infested war three years ago, shortly after her marriage. The only thing that impressed him is Doruntine's description of her long trip as an endless nocturnal ride. Bohemia is about two weeks away from Albania, so it's strange that Doruntine doesn't remember having traveled during daytime. Captain Stres in his report to the Prince's chancellery concludes that either someone deceived Doruntine or Doruntine for some reason has not told the truth.

Stres never expected that Doruntine's return home would arouse such high attention of the Prince and the archbishop. The Prince ordered him to bring the affair to light, "so as to forestall any uneasiness of misapprehension among the people" (44). The archbishop travelled a long way despite the detestable weather in order to take care of the matter in person. He met with Captain Stres, told him the importance of the incident, and asked him to bury it by all means. The Church was alarmed by the repercussions of the incident, because the belief in Constantine's rise from grave is tantamount to Jesus Christ's resurrection and would therefore damage the foundation of the Church.

At the beginning, Captain Stress called it "insane" to believe that it was Constantine who brought Doruntine back. He tried all the possible ways to collect useful information but could not figure out a reasonable and acceptable answer to the mystery. The arrival of the cousins of Doruntine's husband from Bohemia strengthened his conjecture that Doruntine had lied to him. The note Doruntine wrote before she left and the women who saw the horseman take away Doruntine all point to the fact that Doruntine travelled thirteen days on her journey home. 
Toward mid November, one month after the incident, Stres found himself unconsciously enter the cemetery to visit the graves of Vranaj family. As he was looking at the graves covered by snow, he had an epiphany which gave him a strange mental clarity. All at once Doruntine's story seemed perfectly clear: it was Constantine's spirit that brought Doruntine home.

Therefore, when a suspect, an icon-seller by profession, was captured near the Inn of the Two Roberts in another principality and sent to him for interrogation, Stres did not really believe his made-up story. The man was found lying in the road burning with fever and murmuring things like "There is no need to hurry so. What will we say to your mother? Hold on tight, I can't go any faster, it's dark. Don't be afraid, none of your brothers is still alive" (124). The suspect confessed that he was the imposter and on the way to Doruntine's home he seduced her into having sexual relations. However, something in his confession betrayed him and he was held in complete isolation under Captain Stres' control.

Meanwhile, Stres spent much time discussing with Constantine's four best friends on many subjects, among which $b e s a^{l}$ had always been the favorite topic. It was through these conversations that Stres found out what Constantine thought of besa and came to understand that "it was a sort of fulcrum, the theme on which all the rest was based". (157)

The Church was glad that the rumor was finally fading away, and people were talking about Doruntine's travel with the imposter. Great assembly was being prepared to celebrate the Church's victory over the alleged resurrection of Constantine. Captain Stres was asked to give an account of the true story at the assembly. To the audience's astonishment, Stres denounced the Church for

\footnotetext{
1 Besa is a crucial word in Albanian culture. It literally means "oath, vow, pledge or promise." It refers to acts of everyday attestation, as well as the truce which ends a blood feud. It is considered as an essential part of Albanian identity.
} 
manipulating the situation, fabricating the story and cheating the public. He declared that it was Constantine and his besa that brought Doruntine back. Stres disappeared forever after the assembly.

Stres's speech at the end of the novel might seem abrupt. But we read carefully the lines that indicate the relationship between Albanians and the Church, we will find it a natural result. Obviously, the Church was viewed as an Other by Constantine, Stres, and most of the Albanian functionaries.

Constantine has never shown much respect for priests while he lived. The archive materials indicate that he is an oppositionist. Attracted by new ideas, he cultivated them with passion, sometimes carrying them to extremes. (76)

Like most functionaries, Stres did his best not to be drawn into religious issues, and he never took the edicts of the Church too seriously. Indeed, he might well have sought some excuse not to respond to the archbishop's summons were it not for the fact that the prince, eager to avoid poisoning relations with Byzantium, had recently issued an important circular urging all officials of the principality to treat the Church with respect. (78)

The details tell what kind of Other the Church is in the eyes of Albanians. For instance, Stres was unhappy about the archbishop's long stay in the Monastery near their area and said to himself:

The old fox had obviously decided to stick around and keep an eye on things. (82)

Just as it is in many other cultures, fox is a symbol of cunning, trickery and camouflage in Albanian culture. Stres has every reason for calling the archbishop "old fox". When he went to meet the archbishop, the archbishop told him straightaway that he was concerned about an alleged resurrection, which only frivolous minds would believe. In explaining why he took all the trouble to travel in severe weather to meet with Stres, the archbishop said: 
I must admit that I never expected the story to spread so far. [...] This affair must be buried. Or rather, one aspect of it, the one that is at variance with the truth, and damaging to the Church. [...] We must deny the story of this man's resurrection, reject it, unmask it, prevent its spread at all costs (70).

When the captain said that he had difficulty in stopping the spread of the story, the archbishop's eyes glittered with a cold flame. He said sharply:

Find a way to make the mourners stop their songs themselves. As for rumor, what you must do is change its course. (71)

You must see to it that this minority [those who do not believe in this resurrection] becomes the majority. (72)

Then, after making sure that the captain himself did not believe the rumor, the archbishop went on to tell him what to do exactly:

There is only one way to manage it: you must find the man who brought the young woman back. Find the imposter, the lover, the adventurer, whatever he is. [...] And if you do not find him, then you will have to create him (72).

Stres understood that the spreading of Doruntine's story had posed a problem for the Church. Not believing that Constantine had risen from the grave and brought Doruntine home, he was ready to do his utmost to find out the truth. However, what the archbishop suggested to him was against his moral values. In other words, he was unhappy to have been asked by the archbishop to solve the problem in a dishonorable way. Cheating, as the novel shows, is one of the frequently used ways for the Church to solve problems. They believe only that the end justifies the means. They adore Machiavelli's approach of instrumentality and use power to push the local authorities into wrongdoing. Therefore, what follows is the archbishop's "frank" words to make sure that the captain realize the importance of the matter:

I think you are aware of the importance attached to these matters at the Center. Many things are forgiven in Constantinople, but 
there is no indulgence whatever for any question touching on the basic principles of the Holy Church. I have seen emperors massacred, dragged through the hippodromes, eyes put out, tongues cut out, simply because they dared think they could amend this or that thesis of the Church. (73).

Obviously, the archbishop is warning Stres to give up any thoughts against the will of Constantinople on matters touching upon the tenets of the Church. But on the other hand, the threat also discloses the macabre crimes the Church has committed over the history to maintain its rule.

To make things more complicated, the Orthodox Church's concern is not only about Constantine's rising from the grave but also about the threat from the Roman Catholic Church. As the archbishop points out:

Today more than ever, when relations between our Church and the Catholic Church have worsened. ... Nowadays your life is at stake in matters like these (73).

Ever since the split of the Roman Empire and the Great schism, the Eastern Orthodox Church and the Western Catholic Church accused each other for falling into heresy. They also fought for the sphere of influence. Albania, a small country situated between the two great powers, was forced or tempted to shift from one side to the other. In this process, the two Churches used all kinds of dishonest and disgraceful means against each other. Quarrels on religious tenets also became a way to disclaim the legitimacy of each other. Such quarrels, as the archbishop pointed out, can be disastrous:

Perhaps you remember that two years ago, after the heated controversy about the sex of angels, the capital came close to being the arena of a civil war that might have led to wholesale carnage (73).

At the time of Doruntine's story, the principality of Arbëria was under the Orthodox control. Therefore the spread of Constantine's rise from the grave can 
become an excuse for the Catholic Church to accuse the birth of a heresy under its nose. The rivalry between the two powers was full of cheating and dirty play. Captain Stres noticed that

The two churches had once more taken up their struggle for the allegiance of the Albanian princes and counts. Information regularly reported to Stres from inns and relay stations suggested that in recent times Catholic missionaries had intensified their activities in the principalities (67).

Not for nothing had Rome, in its hostility, paid the most careful attention to the development of the case. The Catholic monks had surely outdone themselves in propagating this fable of Constantine's resurrection, thereby attempting to deal the orthodox religion a mortal blow by accusing it of a monstrous heresy leading to dual Christs. Things had gotten so tense that there was now talk of a universal war of religion. (152)

The mutual hostility between the two Churches eventually led to war. The alleged goal of Crusades to restore Christianity in Jerusalem turned out to be a disastrous blow to the Orthodox. That is to say, behind the stated sacred goal of the Church lies the politcal motivation for war. Religion, once institutionalized with hierarchy and intermingled with the desire for political power, turns into a mere political instrument for gaining power. And this is more than clear to the Albanian people who are on the fault lines of the East-West political struggle. As a result, their attitude toward the Church has never been fanatic. On the contrary, as the novel shows, they have no respect for the Church and would change their religous identity according to political and economic situations.

Stres had not been particularly impressed by this aspect of Constantine's personality, possibly because he himself harbored no special respect for religion, an attitude that was in fact not uncommon among the functionaries of the principality. And for good reason: the struggle between Catholicism and Orthodoxy since time immemorial had greatly weakened religion in the Albanian principalities. The region lay just on the border between the two religions, and for various reasons, essentially political and economic, the principalities leaned now toward one, 
now toward the other. Half of them were now Catholic, but that state of affairs was by no means permanent, and each of the two churches hoped to win spheres of influence from the other. (78)

Stres was convinced that the prince himself cared little for religious matters. He had allies among the Catholic princes and enemies among the Orthodox. The principality had once been Catholic, turning Orthodox only half a century before, and the Roman Church had not given up hope of bringing it back to the fold. (78)

The Church is supposed to disseminate Jesus Christ's message of love but unfortunately after it became the official religion and a tool for political struggle, it degenerated into an evil-doer, an immoral suppressor of smaller peoples' passion for love, honesty, faith and liberty.

Constantine stands for the high and sublime Albanian morality. He is the soul of Albanian nation, the representative of the Albanian virtue besa. If the archbishop's questions like "by what right does he seek to ape Jesus Christ? What power brought him back from the world beyond, what message does he bring to humanity? (74)" puzzled Stres in the first two-thirds of the novel, he finally got to understand Constantine's idea and message.

Constantine considered besa a bond linking all that was sublime, and he felt that once it and other similar laws had spread and held sway in every aspect of life, then external laws, with their corresponding institutions, would be shed naturally, just as a snake sloughs off its old skin. (160-161)

He [Constantine] held that this reorganization of life in Albania was necessary. These had to do with the great storms he saw looming on the horizon and with Albania's location, caught in a vise between the religions of Rome and Byzantium, between two worlds, West and East. Their clash would inevitably bring appalling turmoil, and Albania would have to find new ways to defend itself. It had to create structures more stable than "external" laws and institutions, structures eternal and universal, lying within man himself, inviolable and invisible and therefore indestructible. In short, Albania had to change its laws, its administration, its prisons, its courts and all the rest, had to fashion them so that they could be severed from the outside world and anchored within men themselves as the tempest drew 
near. It had to do this or it would be wiped from the face of the earth. (162)

From the above two passages, the reader can see the vital importance of besa for the Albanian people. It is the symbol of Albanian national idenity, the sublime quality which unites the people as a nation, and the key factor to resist external institutions. In other words, threatened by the external powers, Albanians can only survive by sticking to something of their own, something that is sublime and eternal. Besa is the inner intrinsic essenticial thing that would protect the Albanian people from being assimilated or destroyed.

Therefore, to deny Constantine's legend is tantamout to the denial of Albanian people's uniqueness and faith. Having realized this key problem, Stres opted to support the theory that it was Constantine who brought Doruntine home. At the assembly which was designed to announce the victory of the Orthodox Church in cracking down on the resurrection rumor, the captain unmasked the dirty work of the Church and declared that it was Constantine, or to be more exact, it was the Albanian people's besa that brought Doruntine back.

It was nothing but a tissue of lies from start to finish. [...] He (the suspect who confessed to bringing Doruntine home) had been paid to perpetrate the hoax. [...] Doruntine was in fact brought back by Constantine. (172-173)

Each of us has a part in the journey, for it is among us that Constantine's besa germinated, and that is what brought Doruntine back. Therefore, to be more exact I would have to say that it was all of us -- you, me, our dead lying there in the graveyard close by the church - who, through Constantine, brought Doruntine back. (175)

He then continued to speak of the trickery and the faithlessness of the empires and the churches in struggling against each other for power. He pointed out that as a nation positioned in-between, the question is: 
in these new conditions of the worsening of the general atmosphere in the world, in this time of trial, of crime and hateful treachery, who should the Albanian be? What face shall he show the world? Shall he espouse the evil or stand against it? Shall he disfigure himself, changing his features to suit the masks of the age, seeking thus to assure his survival, or shall he keep this countenance unchanged at the risk of bringing upon himself the wrath of the age? Albania's time of trial is near, the hour of choice between these two faces. (177)

The remarks, on the one hand, portray the world powers as immoral, using words such as "hateful", "treachery", "evil", etc., and on the other hand, pose the crucial question of identification to the Albanian people, the answer to which is evident.

Referring to the question which had been asked by the archbishop, Stres concluded by stating:

It was to carry the message that Albania has begun to fashion institutions as sublime as the besa that Constantine rose from his grave. But it's not easy to accept this message. [...] Its burden will be heavier than the cross of Christ. (177)

Here Stres is warning his fellow Albanians of the dangers that lie ahead, if they do not succumb to either of the two powers next to their country. The Churches have exploited all kinds of evil and immoral means to suppress the Albanian identity and they will certainly continue to do so. Stres's disappearance at the end of novel further provides evidence for the immorality and evilness of the Christian Church.

As can be seen from above, the novel Doruntine reveals the deceptive ways of the Orthodox Church to suppress the sublime Albanian identity besa, the frictions between the Orthodox and the Catholic Churches, as well as the conspiracies they resorted to in order to gain the upper hand over the other. Through condemning the intrigues of the Christian Church, the representative of the Western civilization, the author actually aims to reinforce in Albanian people's mind the Western image as an 
immoral Other and a vicious threat to the existence of Albanian nation.

\subsection{Discussion}

The West has been presented or mentioned as an Other also in Kadare's other works; for example in The File on H., when the two Harvard scholars went to the Albanian Embassy for visas, they noted that the consul stared at them "with an obviously suspicious eye" and realized that they had been assumed as agents (51). ${ }^{1}$ And after they arrived in the town $\mathrm{N}$ - in northern Albania, they were suspected to be spies sent by their institution, i.e. Harvard University (44) or even doubted by the local governor that "they had come from the other end of the earth for the sole purpose of sleeping with his wife" (53). But it is in The General of the Dead Army and Doruntine, as I have argued on the basis of textual analysis, that the Western Other is constructed to perfection.

Various interpretations have been given to the above two novels I have chosen for the purpose of showing the negative Western Other shaped in Kadare's works of 1960s and 1970s. Let's just take a look at some of the reviews of The General of the Dead Army. Peter Morgan, for example, argues that The General of the Dead Army indicates Kadare was a dissident even in early 1960s. He contends that the novel shows Italy and Germany "moving into a post-war European West symbolized by life and eros, not death," and in contrast "Albania, the victim," is "left behind, a land of death, mired in the past" (76). ${ }^{2}$ Taking into consideration Kadare's age, his bright prospect and his close relations with Enver Hoxha in the early 1960s, this doesn't seem tenable. More acceptable would be Robert Elsie's comment from the perspective of Kadare's writing style that "though he was a political conformist - and

\footnotetext{
${ }^{1}$ Ismail Kadare, The File on H. translated by Barbara Bray. New York: Arcade Pub., 1998.

2 See pages 63-81 of Peter Morgan's monograph Ismail Kadare: The Writer and the Dictatorship 1957-1990.
} 
who could blame him for it at the time? - Kadare was and remained a dissident in domestic literary theory" (746). He points out that Kadare's style in sharp contrast with the prevailing literature of socialist realism was encouraged by Enver Hoxha to show the freedom of intellectuals in Albania. ${ }^{1}$ Edward B. John calls it an antiwar novel while noting that "the sullen Albanians continue to treat the Italians as invaders," whereas Janet Byron points out that through the general's "anxiety, insomnia, nightmares and alcoholism, Kadare wants us to discover a terrifying aspect of Western ways, namely, that these ways serve the forces of death, not life" (615). She observes that "Albanians are portrayed as vigorous, self-controlled, altruistic and proud in contrast to Westerners, who are debilitated, sexually lawless, selfish and greedy. Whatever vice exists among Albanians is imported (615),"3 which is quite different from the Erica Weitzman's point of view: the novel is also implicitly an examination of the history of post-war Albania itself, which emerged from centuries of occupation - first by the Ottoman Empire and then by fascist Italy - only to fall under the paranoid leadership of Enver Hoxha's [...] Party, ..." (285). ${ }^{4}$

It is natural that critics of different backgrounds would produce different interpretations. However, to avoid misreading, the interpretations must be based upon the historical context of the time when the novels were written, the purpose of the novels and their target readers. It is important to bear in mind that Kadare's works are politically oriented and serve particular political purposes that would also benefit Kadare himself. As pointed out by Harold B. Segel, "Widely regarded as a champion of democracy in Albania - he went into exile only in 1990 - Kadare was nevertheless

\footnotetext{
${ }^{1}$ See Robert Elsie's review of The General of the Dead Army in World Literature Today, Vol. 65, No. 4 (Autumn,1991), pp. 746-747.

${ }^{2}$ See Review of The General of the Dead Army, by St. John, Edward B. Library Journal. 8/15/2008, Vol. 133 Issue 13, p. 68.

${ }^{3}$ Janet Byron, "Albanian Nationalism and Socialism in the Fiction of Ismail Kadare", World Literature Today, Vol. 53, No. 4 (Autumn, 1979), pp. 614-616.

4 Erica Weitzman, "Specters of Narrative: Ismail Kadare's The General of the Dead Army". Journal of Narrative Theory 41.2 (Summer 2011): 282-309.
} 
on good terms with the Albanian dictator, Enver Hoxha, and wrote his share of obligatory anti-American and Party-pleasing works" (271). ${ }^{1}$

The Albanian national consciousness awakened during the National Rebirth Movement in the 19th century, which culminated in the Albanians' declaration of independence in 1912. However, in the following three decades, due to the turmoil during the two world wars, as well as the lack of modern infrastructure to develop a sense of an overarching community beyond local ones, the new Albanian state was not able to foster national conceptions. It was not until the communist era, during which the modern infrastructure was set up, that the Albanian grassroots formed a clear and strong consciousness of their national identity.

Enver Hoxha contributed significantly to the construction of Albanian national identity. He became the leader of Albanian Communist Party during WWII and maintained his rule in the country until his death in 1985 . The construction of a new Albanian identity was precisely what Hoxha aimed during his regime. He sought to make Albania, probably the least developed nation in Europe, into a modern industrial society. In order to achieve this, allegiance of its citizens to the new communist Albanian state was a must. If we say that the Albanian Resistance War against Fascist and Nazi invasions would not have succeeded without nationalistic spirit, the same can be said for the construction of the new Albanian national identity.

Therefore, during Hoxha's reign, there existed, in Fatos Lubonja's words, "the symbiotic syncretism of [nationalist ideology and communist ideology] ideologies, under which the Albanians were kept unified and at the same time dominated by the Communist Party for fifty years".2 In the 1940s and 1950s, the West, being the

\footnotetext{
${ }^{1}$ See Harold B. Segel's review of Remaining Relevant after Communism: The Role of the Writer in Eastern Europe by Andrew Baruch Wachtel, Chicago: U of Chicago Press, 2006.

${ }^{2}$ Fatos Lubonja, "Between a Virtual World and a Real World", Schwandner-Sievers and Fischer (eds.), Albanian Identities: Myth and History, Bloomington \& Indianapolis: Indiana University Press, 2002, p. 94.
} 
newly-driven-out foreign invader of Albania and the ideologically reactionary force, logically became the target Other, the necessary opposite for shaping the Albanian national Self identity. In the 1960s, the breakup with the Soviet Union pushed the Albanian government to reinforce the Western Other in public imagination, since the pro-Western forces were secretly hoping for the establishment of a West-friendly regime. ${ }^{1}$ Then toward the end of 1970 s, Albania was challenged by severe economic problems because China finally cut all the financial aid. The main reason for Albania's break-up with China was, at least on the surface, ideological divergence. China was at that time moving toward its opening up policy and was in the process of establishing normal diplomatic relations with the U.S., which was criticized strongly by the Albanian government as revisionist. Hoxha maintained his anti-Western politics, anti-American in particular, and chose isolation for the future of his country, claiming that it was the only way to keep Albanian nation's independence and sovereignty.

It was under these political circumstances that Kadare wrote The General of the Dead Army and Doruntine. By depicting the West as the hostile aggressor and immoral evil-doer, the novels aimed to incite the nationalist sentiment among the Albanians and to instigate their animosity toward the West. In other words, the novels accommodate the Albanian official ideology of that time and serve to educate the Albanian public that though the West looks mighty and materially better off, the socialist Albania with a sublime cause was more progressive and had no aspiration to identify with it.

In order to construct a national identity which is deeply rooted, Kadare invokes history and legendary stories as evidence for Albanian nation's antiquity. The German

\footnotetext{
${ }^{1}$ The desire of the persecuted bourgeois class to join the Western Camp is depicted emphatically throughout Kadare's novel on Albanian-Soviet breakup The Great Winter.
} 
social historian Robert Michels has suggested two basic myths of patriotism - the myth of unique national origin (der Mythus der Wohher) and the myth of unique national destiny (der Mythus der Wohin). ${ }^{1}$ Kadare is adept at employing the myth of origin and the myth of mission; thus he is called by Morgan "the voice of Albania's modernity and the singer of its ancient identity". 2 The two novels analyzed in this chapter show clearly this feature of Kadare's creation. Myths like Gjergj Elez Alija's fight against the monster from the sea, the birth of Besa, the story of Doruntine are all used to build Albanian nation's unique identity. By means of myth, the West is presented as an aggressive and oppressing evil Other of the Albanian nation.

In their book Occidentalism: The West in the Eyes of Its Enemies, Ian Buruma and Avishai Margalit write, "The dehumanizing picture of the West painted by its enemies is what we have called Occidentalism" (5). ${ }^{3}$ Talking about the anti-Western ethos in late $19^{\text {th }}$ century Japan, they point out that the desire to overcome Western modernity in 1930s Japan was as strong among some Maxist intellectuals as it was in right-wing chauvinist circles. Some of Kadare's 1960s and 1970s writings, together with the writings of the same nature in the former communist countries, constitute part of this Occidentalist discourse.

\footnotetext{
1 Robert Michels, Der Patriotismus, Munich: Duncker u. Humblot, 1929.

2 Peter Morgan, "Ismail Kadare: Modern Homer or Albanian Dissident?" World Literature Today, September 1, 2006, vol 80, No. 5, pp. 7-11.

${ }^{3}$ Ian Buruma \& Avishai Margalit, Occidentalism:The West in the Eyes of Its Enemies, New York: The Penguin Press, 2004.
} 


\section{CHAPTER 3 THE ORIENTAL OTHER}

\subsection{Background}

In his landmark study entitled Orientalism, Edward Said argues that the Orient, including the Near and Far East, is a Eurocentric term constructed by the Westerners to help the Europeans feel superior to those they perceived as non-European. As a result a persistent system of cultural stereotyping ensued where, in opposition to the rational and virtuous West, the Orient is always associated with "Oriental despotism, Oriental splendor, cruelty, sensuality ... promise, terror, sublimity, idyllic pleasure, intense energy" (1978: 4, 118). ${ }^{1}$ Thus, according to Said, the Orient refers to the regions east of the Mediterranean which have been viewed by Europeans as exotic lands full of romance and intrigue, the home of despotic empires and inscrutable customs.

However, for different people of different times, the reference of Orient varies. In a broader sense, the Orient can also refer to the region south of the Mediterranean, i.e. North Africa. For the French, for example, the Orient was a popular concept largely equivalent to North Africa and the Middle East, though for the generation around 1900 it also referred to the Far East. Some of the well-known literary and art works reflecting the Orient are French, including Hugo's poems Les Orientales (1929), paintings of harem scenes and scimitar-wielding warriors by Ingres,

\footnotetext{
${ }^{1}$ Edward Said, Orientalism. London: Pantheon Books, 1978.
} 
Delacroix, Renoir, etc. ${ }^{1}$

For the Balkan nations, if you ask them now what comes up into their mind about the Orient, the answer is probably the Islam world and the Far East like India and China. In other words, while the Westerners view the Balkans as "semi-developed, semi-colonial, semi-civilized, semi-oriental" (Todorova 16) ${ }^{2}$, most Balkan people tend to exclude themselves from the category of Orientals. This tendency first appeared in the nineteenth century, when the Balkan nations started to liberate themselves from the four-century-long Ottoman rule.

For the Albanians, as Enis Sulstarova has shown in his monograph Escape from the East, ${ }^{3}$ the Orient became an Other to the Albanian nation when the Albanian elites of the $19^{\text {th }}$ century found it an urgent must to abandon the collapsing Ottoman Empire and start the process of westernization. In other words, from the time it appeared as an Other to the Albanians, the Orient has referred specifically to Turkey, the Asiatic Ottoman ruler which ruled the Albanian nation for centuries, obstructing its return to the civilized and modernized Europe.

The nationalist ideas rose relatively later in Albania than in the other Balkan nations. One of the important reasons is that in the $19^{\text {th }}$ century Albanians were divided in three different religions, with the majority being Muslims. Many Muslim Albanians held high positions in the Ottoman army or administration, and as a result their interest was closely related to the Ottoman Empire. Moreover, the Albanians feared they were too weak to fight against the neighbors and the territories populated by Albanians would be partitioned among the countries of the Balkan Alliance. Therefore they were only seeking self-governance within the boundaries of the

\footnotetext{
${ }^{1}$ For French literary Orientalism, see Rana Kabbani, Europe's Myths of Orient (Bloomington, Ind., 1986). For Orientalist art see Philippe Jullian, The Orientalists: European Painters of Eastern Scenes, trans. Helga and Dinah Harrison (Oxford, 1977).

${ }^{2}$ See Maria Todorova, Imagining the Balkans. New York: Oxford University Press, 1997.

${ }^{3}$ The original title in Albanian is Arratisje nga lindja: Orientalizmi shqiptar nga Naimi te Kadareja (Escape from the East: Albanian Orientalism from Naim to Kadare). It was published in Tirana in 2006.
} 
Ottoman Empire till they understood this option was no longer possible. Finally, the severe measures taken by the Sublime Porte against the opening of Albanian language schools and the spreading of national consciousness were also a big obstacle for the Albanian National Revival Movement to move forward toward statehood establishment.

As a result of the Sublime Porte's suppression, the Albanian National Revival Movement was directed mainly from the Albanian Diaspora in Italy, Greece, Romania, Switzerland, etc. Most of the magazines in Albanian at that time were published in these Diasporas. Meanwhile, the influential ethnic Albanian intellectuals in Istanbul such as Sami Frashëri also played a crucial role in the movement. These Albanian national revival leaders were well-educated and significantly influenced by the Western culture and the Western ideology of nation state. They strove to eliminate the Ottoman legacy in the political, social and cultural fields, aspiring to form an Albanian nation state within the civilized Europe. For example, Naim Frashëri, the greatest literary figure of the Albanian National Revival Morvement, made tremendous efforts in establishing a separate Bektashi order ${ }^{1}$ as the major Albanian religion so that Albania's ties with Turkish Sunni Islam could be severed. In addition, he also worked hard to create new words using Albanian roots and affixes to replace the Turkish loan words. Apart from eliminating the Turkish influence, as Jokl noted, Naim Frashëri did not seem to bother with the vocabulary absorbed from other languages (1926:229). ${ }^{2}$

In their efforts to become part of Europe, as observed by scholars like Piro Misha, Noel Malcolm, Sulstarova, etc., the Albanian Renaissance intellectuals claimed to be

\footnotetext{
${ }^{1}$ The Bektashi Order is a Sufi order and shares much in common with other Islamic mystical movements. It places much emphasis on the concept of "unity of being". Bektashis have no specific doctrines. Religious tolerance and flexibility is its prominent feature because Bektashi rules and rituals may differ depending on under whose influence one has been taught.

${ }^{2}$ Norbert Jokl, "Die Bektaschis von Naim Frashëri," Balkan-Archiv, vol. 2 (1926), pp. 226-256. For an English translation see Hasluck, F. W. 1929. Christianity and Islam under the Sultans. Edited by M.M.
} 
the descendants of Pelasgians, an ancient people mentioned by classical writers as early inhabitants of Greece and the eastern islands of the Mediterranean. ${ }^{1}$ Many Albanian words were explained from the etymological perspective and used as proof for the theory of Albanian nation's Pelasgian or Illyrian descent. By this they wanted to show that Albanians, together with the Greeks, contributed to the origin of the European civilization and therefore should have the right to share the modern European civilization. $^{2}$

Moreover, in order to seek Western help and distance itself from the Ottomans, the Albanian Renaissance pioneers highlighted Albanian people's anti-Ottoman resistance under George Kastrioti-Skanderbeg's leadership in the fifteenth century, ${ }^{3}$ which stopped the Ottomans from moving westward. During the Albanian Renaissance, Skanderbeg's heroism was turned into a historic myth, which, as underlined by Schopflin, is an essential element for social cohesion and national identity construction (9). ${ }^{4}$ The uprising of Skanderbeg and the enduring resistance added further touches to the collective identity of the Albanians as a people determined to defend their freedom. At the same time, the myth was exploited to portray the Ottoman Empire as an Oriental Other which placed the Albanians under its yoke for centuries.

The Ottomans continued to be viewed as the Oriental Other after Albania proclaimed its independence in 1912. In the period between the two world wars, Fan

\footnotetext{
${ }^{1}$ Definition from Merriam Webster Dictionary online, http://www.merriam-webster.com/dictionary/pelasgian, accessed on March 31, 2013. The Albanians claim their Pelagian origin to prove that they are an ancient European people.

${ }^{2}$ See Piro Misha's "Invention of a Nationalism: Myth and Amnesia" p. 42 and Noel Malcolm's "Myths of Albanian National Identity: Some Key Elements, as Expressed in the Works of Albanian Writers in America in the Early 19th Century." pp.76-79 in Albanian Identities: Myth and History. Ed. Stephanie Schwander-Sievers and Bernd Fischer. Bloomington: Indiana University Press, 2002. Also see Sulstarova, Escape from the East: Albanian Orientalism from Naim to Kadare, p. 43.

${ }^{3}$ George Kastrioti was sent as a child hostage to Sultan Murad. He reached the rank of general when he was only twenty-two. In 1443, taking advantage of the wars waged by the Hungarian general John Hunyadi, he proclaimed a rebellion, returned to his country and united the Albanian forces to fight against the Ottomans.

${ }^{4}$ See "Nature of Myth: Some Theoretical Aspects" in Schwandner-Sievers, Stephanie. \& Fischer, Bernd. eds., Albanian Identities: Myth and History. Bloomington: Indiana University Press, 2002.
} 
Noli, an American-educated Orthodox bishop attempted to modernize and Westernize Albania, though his democratic revolution lasted only half a year. Ahmet Zogu ruled for 14 years, first as president (1925-1928) and then as King Zog I (1928-39), during which he made a few steps forward to Westernize Albanian social life, and further differentiated Albanians from the Oriental Other.

When the Albanian Communist Party came to power, Albania' situation was no better than that before the Second World War. According to the French journalist Delaisi, Albania was so closed to civilisation that even Sahara is better known and Tibet cannot be said to be more mysterious. ${ }^{1}$ Among the population of 18000 people in the Northern Albanian region of Mirëdita on the eve of WWI, only three people could write and read. ${ }^{2}$ In mid-1940s, still very few people could read or write in Albanian. The poor consciousness of national identity among the Albanians during the Second World War was clearly presented by Kadare in his work Chronicle in Stone, where the majority of people still tended to identify themselves as muslims.

During the communist reign, tremendous efforts were made to change the backward situation. In order to enhance people's national pride and strengthen the authority of the Communist Party, propagandistic emphasis was placed on the nation's ancient history and the Party's role as the saviour who finally saved the people from all kinds of oppression and exploitation. Kadare's poem What Do These Mountains Think About (1963) was one of the most influential works of this type. Nationalist ideas were reinforced through school teaching. Textbooks were filled with materials designed to convince the youth that "they had a splendid history and that the national calamities were not a reason to cool them down about the fatherland, but on

\footnotetext{
${ }^{1}$ Francois Delaisi, Les aspirations autonomistes en Europe, Paris: Alcan 1913, p. 23.

${ }^{2}$ Faik Konica, Parashtresë mbi lëvizjen kombëtare shqiptare (Memorandum on the Albanian National Movement)

- Vepra (Works), vol. 2, Prishtina: Rilindja. p. 9.
} 
the contrary, to stand closer to it". ${ }^{1}$ In a word, Enver Hoxha held high the nineteenth century nationalist flag in the process of building the new modern and progressive socialist Albania. Naturally, Skanderbeg, who was transformed into a national symbol during the Albanian Renaissance, continued to serve as an important factor for national cohesion and national pride, whereas the Ottomans continued to be presented as the Oriental Other which deprived the Albanian people of the oppotunity of industrialization and modernization. Skanderbeg was glorified, but this time a direct link was drawn between him and Enver Hoxha in an attempt to portray the Party leader as the heir to Skanderbeg. History, as pointed out by Piro Misha, served to legitimise Albanian communist leaders and their politics and "during the communist period this logic reached Orwellian dimentions in the faking of historical phtographs and document (47). ${ }^{2}$

Meanwhile, Albania's relationship with the Soviet Union and China during the Albanian communist regime bestowed a wider spectrum to which the Oriental Other refers. After Stalin died in 1953, there was a decline of Soviet Union's military and political interest in Albania. Khrushchev seemed to believe that the high cost of economic aid to support Albania was not a worthwhile investment to serve the Soviet strategic interests. In 1954, the Soviet Union and East European countries reduced their aid to Albania. To make things worse, Khrushchev visited Belgrade in May 1955 and admitted that there could be many roads to socialism. Hoxha felt betrayed by Khrushchev, particularly by his rapprochement with Tito. (O’Donnell 39) ${ }^{3}$ After finding support from China, which was also unhappy with Khrushchev and his reforms, Albania openly defied Khrushchev. In 1961 the deteriorated relations

\footnotetext{
${ }^{1}$ Ismail Kadare, Kombi shqiptar në prag të mijëvjeçarit te tretë (The Albanian Nation on the eve of the Third millenium). Tirana: Onufri. 1998, p.12.

2 Piro Misha's "Invention of a Nationalism: Myth and Amnesia" p. 42 in Albanian Identities: Myth and History. Ed. Stephanie Schwander-Sievers and Bernd Fischer. Bloomington: Indiana University Press, 2002.

3 James S. O'Donnell, A Coming of Age: Albania under Enver Hoxha, New York: distributed by Columbia University Press, 1999.
} 
between USSR and Albania eventually led to the breaking of diplomatic relations between the two countries. Ten years later, when China started to adjust its diplomatic strategy and considered USA as the secondary enemy, Hoxha insisted on his "dual adversary" stance, claiming that "Both of them [the US and the USSR] are dangerous and must be combatted sternly" (108). ${ }^{1}$ In 1977 , when Tito was warmly received in Beijing, Albania was hit by the last straw. In 1978 China cut all financial aid to Albania and didn’t pay any high-ranking official visits to Albania until 1991.

Thus, after the break with the Soviet Union in 1961 and with China in 1978, Albanian people were steered to regard the two ex-friends as the Oriental Other as well. In other words, apart from the Ottoman Empire, which was presented as the Oriental Other from the historical perspective, Albania had two actual Oriental Others: the Soviet Union and China.

In 1976, Enver Hoxha took all sorts of preventative measures such as changing Albania's constitutional name, making constitutional amendment to prohibit the government from accepting foreign aid, etc. in order to ensure that Albania would not fall pray to foreign economic "aid". ${ }^{2}$ Unfortunately, five years after his death, Hoxha's statue was pulled down by angry students and he himself, as the representative of the Albanian tatalitarian regime, became part of the Oriental Other of the Albanian nation.

Kadare, witnessing all the political changes over the past six decades, has treated the Oriental Others mentioned above in many of his works. Employing history for actual political purposes, Kadare has constructed the Ottoman Other to allude to

\footnotetext{
${ }^{1}$ http://www.enverhoxha.ru/Archive_of_books/English/enver_hoxha_reflections_on_china_volume_II_eng.pdf, online source, Enver Hoxha, Reflections on China, vol. 2, Tirana: 8 Nentori, 1979, accessed on Feb. 15, 2013. 2 http://bjoerna.dk/dokumentation/Albanian-Constitution-1976.htm, online source, "The Constitution of the People's Socialist Republic of Albania," approved by the People's Assembly on December 28, 1976, republished for the record, by Bjoern Andersen, March 2005. Article 28 of the constitution prescribes: "The granting of concessions to, and the creation of, foreign economic and financial companies and other institutions or ones formed jointly with bourgeois and revisionist capitalist monopolies and states, as well as obtaining credits from them, are prohibited in the People's Socialist Republic of Albania."
} 
Albania's actual Others in reality, namely the Soviet Union, China, Islam and Communism. As a result of Albania's imbalanced relationship with the Soviet Union, the Oriental Other is depicted as hegenonic. Influenced by the Orientalist discourse, Kadare depicts the Oriental Other as insidious. And finally, as a result of his increasingly sober awareness of the oppressive nature of dictatorship, Kadare denounces communism as the totalitarian Other, subtly in the 1980s and blatantly after 1990.

I will focus on three of Kadare's works, The Castle (1970), The Three-Arched Bridge (1978) and The Palace of Dreams (1981), which I view as the most appropriate works to analyze the Orienatal Others depicted by Kadare. Nevertheless, in order to give a broader view of the Oriental Other presented by Kadare, works such as The Great Winter (1973), The Concert (1988), The Pyramid (1992), etc. that reflect the Soviet-Albanian and Sino-Albanian relations as well as the post-communist context will also be touched upon for some cross-analysis.

\subsection{The Hegemonic Other}

The common understanding of hegemony is an indirect form of government of imperial dominance in which the hegemonic state rules geopolitically subordinate states by the threat of force or economic punishment. However, in a broader sense, hegemony does not exclude the direct use of military force. In his work Hegemony or Survival: America's Quest for Global Dominance (2003), Noam Chomsky argues that the USA has pursued an "Imperial Grand Strategy" since World War II in order to eusure its global hegemony. Among the historical examples he drew from 1945 to 2003 to support his argument, Chomsky used the Vietnam War, NATO bombing of Yugoslavia, Afghan War and Iraq War as evidence for direct military interventions by 
US. He points out that in order to maintain global dominance and grasp more resources, the "American Empire" has resorted to various military, political and economic means and in the future the U.S. foreign policy will follow the same agenda. $^{1}$

In this dissertation, hegemonic Other refers to a superpower state or an empire which employs all kinds of means available to maintain dominance, including military, political, economic, cultural, religious, etc. Anyone who has some basic knowledge about Albanian history would think of the Ottoman Empire and the Soviet Union in the first place. Indeed, in Kadare's work The Castle (1970), we find a hegemonic Ottoman Other, which, after failing to win back Skanderbeg by means of coaxing and threatening, resorted to military force to punish the small rebellious Albanian nation under Skanderbeg. The allusion is clear: Ottoman Empire equivalent to the Soviet Union and Skanderbeg equivalent to Enver Hoxha.

The Castle is a fictionalized recounting of the armed resistance of the Albanian people under Skanderbeg against the Ottoman Turks. It recreates the struggle between the mighty Ottoman superpower and the tiny but unbending Albania. Set in the early 15th century, it chronicles an Ottoman Turkish army's attack on the Albanian fortress sequestered in the awe-inspiring mountains. The besieged Albanians appear in the novel as "we", i.e. in a unified first person plural, occupying only a 1-2 page short account before every chapter. Skanderbeg, the hero of the novel, waged a guerrilla campaign against the Ottomans from his mountain hideout. He is mentioned frequently but never seen. Nevertheless, from the mouths of the besieged "we" and the besieging "they", the readers are given to understand Skanderbeg's wisdom, his heroism, his own people's trust and the enemy's fear of mentioning his name. The

\footnotetext{
${ }^{1}$ Noam Chomsky, Hegemony Or Survival: America's Quest for Global Dominance. Sydney: Allen \& Unwin, 2003.
} 
depiction of the Ottoman army occupies more than ninety percent of the novel's length, and it is realized through many individual figures such as the Pasha, the chronicler, the astrologer, the intendant-in-chief, the cannon-making engeneers, the army doctor, the generals and the soldiers, etc. The desperate psychology of the Pasha who led this punitive expedition, the omnious signs associated with him, as well as the conflicts between the two factions under his command predetermine the outcome of this battle, i.e. the Ottoman force is foredoomed to failure. It is no surprise that the novel ends with the Pasha's suicide and the miscarriage of one of his women, who got preganant on the Albanian land.

Kadare proves himself to be good at imagining war scenes and war tactics. The story is rather intriguing and heart-gripping for the reader. After the Ottoman troops settled down and put up their tents, the Pasha's war council met to discuss the time for launching the initial attack. There were two opposing opinions: the learned people, including the head of the foundry, the intendant-in-chief and the architect, suggested the battle be lauched when the bombards are ready, whereas the military men, apart from the captain of azaps $^{1}$, asked for immediate battle. The captain of azaps did not want an immediate launch because his division would be in the first lines to climb the walls of the castle. The ferocious battle started the second day, but converse to the claimed dream that the crocodile tore out a black bull's heart, ${ }^{2}$ it turned out to be a disastrous blow to the Ottoman army. After this, the Pasha had to change his tactic, and adopted the architect's suggestion of attacking the castle from underground. The tunnel digging however was soon discovered by the vigilant Albanians and the plan ended up with all the digging soldiers buried alive under the castle. The two failures

\footnotetext{
${ }^{1}$ Azap is a Turkish word with Arabic origin, meaning bachelor. Azaps were irregular light infantry of the Ottoman army.

${ }^{2}$ Here the crocodile refers to the Ottoman Empire and the black bull to Albania. However, in The Three-Arched Bridge, we find Kadare use crocodile and tiger to describe the fight between the West and the East.
} 
left the Pasha no other choice but to cut the castle's watersupply. Days passed but the architect still could not find the water pipe leading to the castle. Finally a thirsty horse fed with salt and barley was led to the site to seek the pipe. When the horse found the pipe, the Pasha laughed for the first time since he had set foot on the Albanian land. He was sure that, deprived of water, the defenders would not be able to hold on more than a week. Fearing that the rainy season was approaching, the Pasha decided to launch a fatal attack. To his dismay, fate was not on his side. When he almost saw the light of victory, one of the cannons fell mistakenly on his own soldiers. The accident gave courage to the army doctor to suggest the use of infected rats. Desparate as he was, the Pasha was ready to use every means, be it moral or immoral. When signs for rain appeared, the Ottoman army intensified their attacks. But none of these attempts helped him. Neither did the infected rats put into the castle deal a lethal blow to the castle defenders. The Pasha became increasingly conscious that the doomed defeat was approaching and everybody was trying to abandon him for self-protection.

The accounts of the Ottoman army's initial attack, their attempts of taking over the castle from underground, the horse's detecting of water pipe, the use of infected rats, plus the accidental blow of the cannon, the disputes among the learned and the military people in the Ottoman army, etc. are so intriguing that the reader is attracted to finish reading at one breath. Nowadays the publisher gamely interprets the novel as presenting the eternal clash of civilizations between Christians and Muslims. But at the time when the novel was published, no Albanian would fail to catch the major theme: the heroism of Albanian people under Skanderbeg's leadership in their resistance against the mighty hegemonic Ottoman enemy. Neither would the readers fail to establish a parallel between the historical events and the Albanian-Soviet conflict in 1960, when Albania was facing the Soviet-led economic and political 
blockade. Albania was alone and surrounded, alienated from both the Warsaw Pact nations and the West. The Soviet invasion of Czechoslovakia in 1968 alarmed Albania and pushed Albania to take radical defensive measures, reslut of which remains even today: up to seven hundred and fifty thousand concrete bunkers all over Albania. The title of the novel ${ }^{1}$ suggests an association with the bunkers and symbolizes Albania's determination to fight agaisnt any incursion. The Ottoman-Soviet allusion shows how history repeats itself. It also legitimizes Hoxha's policy, lauding him as the heir to Skanderbeg.

Most of the story follows Mevla Çelebi, who was assigned to write "an immortal chronicle on the one of the most terrible battles what will take place" (25). The talks between Çelebi and his high-birth friend, the intendant-in-chief in charge of Ottoman army's food supplie, are the most important part of the novel, through which the author reveals the nature of the hegemonic superpower and the hegemonic mentality of the imperialist elite.

The use of monstrous war-machinery against a small nation itself speaks for the Ottoman hegemony. As shown in the novel, at the beginning the Sultan sought an amiable solution to the Albanian problem. But when that didn't work, he immediately turned to accusations and threats, which were finally replaced by punitive expedition.

They [the Great Turk] exerted all sorts of pressure to force us into suzerainty. At first, they flattered and promised, and then accused us of being ungrateful turncoats, saying we had sold ourselves to the Franks, meaning to Europe. At last they threatened to subdue us by means of war. (7)

A fortnight passed and we received a vassal of the Sultan, who posed as our friend and interceded to bring about reconciliation. But he failed. A month was hardly over before all the vassals of

\footnotetext{
${ }^{1}$ The Castle was originally called by the author as The Drums of Rain. It was first published in 1970 under the title The Castle after being proposed to highlight the presence of the Albanian defenders and their heroic resistance. In the French edition in 1972, it turned back to the original title. After the collapse of the communist regime, the author renamed the novel as The Siege, where he has made remarkable changes to underscore the Hoxha's ridiculous and devastating isolation policy.
} 
the Sultan broke off relations with us at his orders. (7)

This expedition is commanded by Tursun Tundjasllan Pasha. They presented his final terms: no one would be harmed, be they men or women. Everyone of us was free to leave the castle and would be permitted to choose his plot of land down in the valley. Each would be allowed to retain his religion. Their only demand is that we hand over to them the keys of the castle and lower our flag with that ominous black bird, [...] and hoist in its place the half-moon flag of Islam, as Allah has ordered. (20)

Naturally, the Ottoman Empire wouldn't be that kind to allow the local people to live the way they used to or even help them improve their livelihood. What is hidden behind the military conquest with force is the right to exploit those who succumb to the imperialist power. This is evident in the intendant-in-chief words:

During the siege of Trapezunda, at the moment when the first cannon, which was much smaller than this, shot its first shell, many people there had the impression that the mouth of the cannon had roared "Allah!" I was present, went on the intendant-in-chief, "and it seemed to me as though the cannon roared 'Taxes'!" (34)

Not only that, the Ottoman Empire had more to "offer" for the people once they are conquered. In order to dominate eternally, ideological identification of the people under its rule was also a must. In other words, religious conversion should be forced to make the disobedient people submissive.

"We shall teach the sacred Koran to these damned rebels," a sheik was crying with all his lungs. "We shall make these infidels fall prostrate towards Mecca five times a day. We shall wrap their rebel heads in the appeasing turban of Islam." (49)

We shall strip their women and girls of their shameful white dresses and shall wrap them in the blessed black mantle of our religion. We shall veil their faces [...] We shall make them bow down their rebellious heads [...] Thus, turning them from their barbarous ways and giving them for nothing our magnificent moral principles and customs, we shall make honest and virtuous women of them and shall redeem their devil-possessed spirits. (54)

For the Ottomans, taking over the castle is actually the first step toward establishing it hegemony. They knew how difficult it would be to make the rebelious 
Albanians internalize their discourse. The intendant-in-chief illustrated the difficulty

to the chronicler while using language to refer to political discourse.

How difficult it would be to break down something in the construction of this language, even the slight nasal pronunciation. [...] it is even harder than breaking open the castle gates or demolishing these walls. Even the cannons, and the papers of the architect are of no avail in such cases. It requires gigantic efforts. And to achieve this, rivers of Turkish blood will flow upon this soil, rivers of sacred Turkish blood. (127)

The intendant-in-chief went on to explain that in dealing with these tough problems, the Ottoman Empire had a particular group of experts in service who study these questions and invent more refined methods for solution.

The Great Padishah has appointed men to deal with these problems. [...] They are experts in the denationalization of peoples, just as Sarudja is an expert in destroying castles. Day and night they study the methods needed for maintaining peace and quiet through our vast empire. (124)

The methods or suggestions given by the experts include how to minimize the growth of Albanian population so that it wouldn't pose any threat to the Empire in the future. It is suggested that the evil seed like blood feud tradition should be imported to Albania at any cost from Arabia, or "from the kingdom of ice, if necessary", because it is not enough to lower their multiplying capacity "by means of punitive expeditions, massacres, by kidnapping their children to replenish our janissary units, by repeated wars and devastations" (123).

There is a custom in the tribes of the deserts in Arabia, according to which, if a man is killed while quarrelling or falls into a trap, this man should be revenged, even three generations late. This custom ties families in the chains of death, for one murder is followed by another and so on to eternity. Such a custom is worth many victorious battles. I told you there are people in the center whose special concern is the study of such habits and customs. They have thought of all these, including this custom I mentioned. (124)

"Thus we will make sure that they keep to their present number, 
like that kind of dog which does not grow. Have you ever seen such pet dogs? The madams of the infidels in our capital keep them in their houses." (124)

Of course, when direct warfare is involved, it is imperative for the superpower to develop new war technology for the purpose of intimidation and effective punishment. The Ottoman Empire therefore took the cannon technology development as an extremely important way to strengthen itself and guarantee victory on the battle ground. The head of the foundry described the intimidating power of the cannons as follows:

The rumble and roar of my cannons will drive terror into their [Albanian] hearts and diminish their courage and this is no small matter. (35)

The cannons, however, didn't drive terror into the Albanians' hearts. Small as they were, the Albanians proved that they are strong and wise enough to stand against the imperialist threat.

Acting on the instructions of George Castrioti, we started inquiries about that new weapon and learned something. ...but its destructive power was not as great as they claimed. We discovered that those who exaggerated the might of that cannon were precisely those who had maintained that we could not fight against the Sultan. (37)

They had strong faith in their arms and were confident of having us demoralized and thrown into complete disarray, by their roaring guns and bombards alone, at the end of the first day. But the times are such now that we can get used to anything. (79)

The novel also shows the other side of developing advanced technology. The scientists and engineers are presented as victims in the course of the Empire's pursuit of hegemony. The intelligent aide of the head of the foundry was torn to pieces by the angry soldiers because he was responsible for the bomb which accidentally caused dozens of deaths among its own army. And the old cannon designer was put into jail for refusing to continue his work. To a centain extent, people engaged in the 
technology development became hostage of the power-pursuit game. They are not allowed to quit the job even if they realize that their research might lead to the destruction of human race.

If the mouth of the cannon was to be further enlarged, it would become a terrible weapon, which would prove to be the destruction of the human race. The monster was born, he [the old scientist] used to say of the cannon, and we cannot eliminate it, but we should do our best to keep its mouth to the present proportions and not enlarge it, for then it would devour the whole world. The old man stopped his research half-way and the Sultan arrested him. (32)

The cannon described here as a destructive monster should be an allusion to the modern nuclear weapons, as only hegemonic powers had the ability of developing such a monstrous weapon that would destroy the whole human race. In other words, the hegemonic Ottoman Other is constructed to serve actual political purposes: to denounce the hegemony of the Soviet Union as well as the United States. It condemns the superpowers for their irrational pursuit of mass destructive weapon development in order to maintain their hegemony in the world.

Like all the hegemonic powers in history and actuality, the Ottomans were also aware of the importance of collecting information. Military inteligence was one of the key factors they used to rely on for winning the war, and this was done under the cover of religious, cultural or economic activities.

Long before war was declared, an ever increasing number of ragged dervishes, wandering day and night, began to show up in our streets, in our hamlets and towns. The majority of them, as it turned out later on, were secret agents of the Ottomans, collecting every sort of information, economic or military, ranging from the position of bridges and routes by which their army was to pass to the ways our castles were supplied with water. (187)

Notably, the Ottomans did not reject traditional ways such as using a horse to detect the water pipe, nor did they refrain from using biological weapons, as long as it 
would bring them advantage over the adversary. Therefore, when the cannons didn't work as expected, the Pasha agreed to use infected rats against the Albanian defenders. In the army physician's words, a might army should be equipped with all techniques.

A mighty army like ours is, should be equipped with all the techniques of modern warfare, ranging from the camels to transport the bronze for the cannons, to the tiny fleas, and rats. (240)

Finally, the Ottoman hegemonic Other is also presented as a dirty game player.

The Ottomans launched the expedition against Albania because, in the intendant-in-chief's words, the Albanians stepped into their path as an unexpected obstacle when they were rushing towards Europe (124). ${ }^{1}$ However, while punishing Albania for making agreement with Venice, the Ottoman Empire didn't constrain itself from concluding agreements with Venice for food and weapon supplies. If a boss's privilege is asking others to "do whatever I say but not what I do", then the Ottoman Empire was exactly using this hegemonic privilege to play political games.

"I can see why you are so astonished," said the intendant-in-chief. "You must be amazed that we accuse Scanderbeg of having sold himself out to the Franks, while we make agreements with the Franks behind his back. If I were in your position, I would have been as much surprised myself."

$\cdots$

That is politics, Mevla Chelebi! (24)

To summarize, the Ottoman Empire had made every effort against the rebellious Albanians, from huge cannons to infected rats. The novel shows that the Ottoman Empire is a hegemonic Other which would not allow defiance by a small nation like Albania. As pointed out by the intendant-in-chief, they had to chastise the Albanians

\footnotetext{
${ }^{1}$ The nations situated on the borderline between East and West, such as Serbia, Hungary, Poland, etc. often portray themselves as the defenders of Christianity from infidels. Such is the myth created by the Serbian nationalists concerning the Kosovo Field Battle under the Serbian prince Lazar's leadership in 1389. Parallel to the historic myths of this nature by the other in-between nations, Albania also glorifies their national hero Skanderbeg as the defender not only of Albanian independence, defender of Western European civilization. Kadare's paramount task when he published The Castle in 1970 was to portray Skanderbeg as the defender of his nation, an allusion to E. Hoxha's role. Nevertheless, as the continuation of the intellectual tradition from the $19^{\text {th }}$ century Albanian Renaissance, Skanderbeg as the defender of Europe is still visible in Kadare's early versions of The Castle. The latter role of is highlighted in the post-1990 versions of this novel.
} 
promptly and severely because "the prestige of the empire is at stake (125)". The novel depicts from all aspects how the mighty Ottoman Other strove to maintain its hegemony, including tricky temptations, threat of use of force, development of military technology, secret intelligence, use of biological weapons, play of unfaithful political game, holding in possession the think-tank for ideas such as religious assimilation and population curtailment of the small subjugated nations, etc. Though the novel ends with the Albania's heroic victory, the pernicious threat of the hegemonic Ottoman Other is always there, which can be seen from the intendant-in-chief's words.

"This war will endure," said the intendant-in-chief. "Albania must exhaust all her energies in it. This is only the beginning. Every springtime [...] the earth will shake under the tread of our detachments. The valleys will be set on fire and everything that sprouts and grows in them will be reduced to ashes. Their prospering economy will no longer exist. The people of this country will frighten their children with the name of "Turk". [...] They will be used to it [death] as we are used to a tame lion which frightens no one. (229-230)

By and by, with the lapse of years, they will drop their customs as the apple tree drops its flowers. They will get used to our customs and will take them so much to heart that, if, perchance, and God guard us against it, we are obliged to leave this country, they will break from our habits and customs with much pain. (54)

These words predict the future for the Albanians under Skanderbeg. At the same time, they reveal what a terrible hegemonic Other Ottoman Empire has been in the Albanian history. The Ottoman launched incessant expeditions against the Albanians because their hegemonic authority demanded "a tame lion" and an ideologically assimilated vassal.

Many of the plot and dialogues in The Castle can find their echoes in Kadare's another work titled The Great Winter (1973), which was written deliberately to celebrate Enver Hoxha's heroism in confronting the Soviet hegemonic Other. The 
novel focuses on the events concerning the break between Khrushchev and Hoxha. The protagonist Besnik Struga is a journalist who was assigned to be Hoxha's interpreter for the November 1960 Moscow conference of 81 communist parties. The participation in negotiations, receptions and high-level secret talks gave him firsthand experience of political intrigue and power politics. After he returned home, he felt the strong negative effect of his stay in Moscow. The pressure of keeping everything within himself turned him into another person, which led to the breakup of his engagement to his girlfriend. Kadare skillfully presented the political tension and struggle between the tiny Albania and the mighty Soviet Union, as well as the reactions of different social strata to the Soviet-Albanian breakup. Khrushchev delayed grain supplies for Albania and called back the Russian personnel in Albania to show his displeasure with Enver Hoxha's non-conformist attitude. However this did not stop Hoxha from speaking against him and the Soviet hegemonic policy on the Moscow conference. Finally, the Soviet Union conceded its submarine base at the Albanian port city Vlora.

The Soviet Union is portrayed as a hegemonic Other through Khrushchev's remarks and Hoxha's speech at the Moscow conference. During his visit in 1959 to Albania, Khrushchev asked Hoxha to follow the Soviet strategic plan and change Albania into an orchard garden. Hoxha recalled his conversation with Khrushchev when he was negotiating with Soviet high officials during his stay in Moscow:

"Then I remembered comrade Khrushchev's words." continued Enver Hoxha, "Do not grow grains, comrade Khrushchev said to me. You grow vegetables and grapes. We will give you grains. How much grain does Albania produce in a year? When I told him the amount, he laughed and said, that amount of grain is eaten by the mice in the silos of the Soviet Union. And now, when we ask for the part of grain that the mice eat, it becomes a 
problem." $(172)^{1}$

Khrushchev expected that the grain shortage in Albania would force Enver Hoxha to give in. But Hoxha is said to have countered haughtily, saying "We will eat grass rather than give in"! When Khrushchev tried to convince Hoxha in the name of friendship, Hoxha replied:

Our people have a lot of proverbs for friendship. But if you understand friendship as subjugation, we do not want that friendship. (192)

Arguing against Khrushchev's hint that the reason for the cooling-off of the Soviet-Albanian relations was Albanians placing their narrow national interest over the communist interest, Hoxha refuted:

In our friendship with you, we perhaps have been too naïve, because we have been young and without experience, nevertheless we have been sincere. However, it seems that you do not value this kind of loyalty. For you can understand only loyalty obliged by borders, arms and money. (195)

In his speech at the conference, Hoxha shocked all the delegates by accusing Soviet Union for bullying a small nation like Albania:

The only crime of ours is that we are a small party and a small and impoverished people, which, according to comrade Khrushchev's opinion, should only clap our hands to agree rather than express our own thoughts. (205)

Indeed, the Soviet Union had its strategic and geopolitical consideration when it provided aid for Albania. Stalin used Albania as a tool to punish Tito. In the wake of Stalin's death, the Khrushchev's rapprochement with Tito implied a threat to Hoxha's position. Hoxha rejected the demands of rehabilitating the pro-Yugoslav Koçi Xoxe ${ }^{2}$ who was executed after the Hoxha-Tito split, because, in Biberaj's words, "accepting

\footnotetext{
${ }^{1}$ There is not English version of The Great Winter published. All the translations are made by the author of the dissertation from the fifth volume of Kadare's complete works, where the novel is under its original name Dimri $i$ vetmisë së madhe (The Winter of Great Solitude).

${ }^{2}$ Koçi Xoxë was the Albanian interior minister before he was executed during 1945-1948. In 1948, when Hoxha successfully got rid of Tito's control, K. Xoxë was purged for "pro-Yugoslav activities". He was executed in 1949. 
them would have been tantamount to committing political suicide" (26). ${ }^{1}$ He would not allow Koçi Xoxe's phantom to haunt him and threaten his regime. Consequently, in the name of defending the Albanian national interest and the genuine Marxism, Hoxha defied Khrushchev and the mighty hegemonic Soviet Empire. The Soviet Union, on the other hand, attempted to use all means to force Albania to give in. In order to stop Hoxha from launching open attack on the conference, Khrushchev threatened him with complete loneliness in the socialist camp.

"If you are going to expose the disputes between us, you will remain lonely" said Khrushchev, "not only on the conference, but forever. You will be completely lonely. The socialist countries will turn their back to you one after another. All the agreements, loans, treaties, alliances will be disacknowledged. Everything will be ruined until you..." (199)

On the welcome banquet for the participating parties, Besniku saw many of the retired Soviet generals, an obvious arrangement to show teeth to the tiny Albania. Some aviator accosted Besniku and argued that in the socialist camp each country should play its own role according to the regulations.

You have a bird on your flag, don't you? This is great, poetic. [...] but in order to fly, you need to have a lot of grain and iron. [...] When a squad flies, everybody should be in his own position. It's always like this everywhere. I am referring to the socialist camp. We are a great powerful camp, a threat to imperialism. However, in the camp there should be regulations, otherwise there will be chaos, which the enemy is waiting for. I was having this in mind when I said that someone should walk on foot and someone should fly. (148-149)

History is evoked in the novel to show that Albania has always been threatened by the great empires whenever it refuses to subjugate. For example, when the Albanian Foreign Minister was waiting for the Soviet Ambassador to present Soviet decision to cut diplomatic relations with Albania, his mind flew back to the ancient

\footnotetext{
${ }^{1}$ Elez Biberaj, Ph.D. dissertation: Albania and China: 1962-1978, a Case Study of a Bilateral Unequal Alliance, Columbia University, 1985.
} 
Albanian kingdom which was threatened by the Roman Empire and saw in his imagination the Roman ambassador was ascending the stairs to present the Roman ultimatum to Queen Teuta. (566) And in the library, Besniku's friend Diana was frightened by the menacing dragonscale-like shelves holding all the ultimatums Albania has received throughout history, from Illyrian kingdom to $20^{\text {th }}$ the century Albania. (259) Soviet Union, consequently, was viewed by the Albanians as the "third Roman Empire", a contemporary red hegemonic empire. (143)

There are quite a few parallels between The Castle and The Great Winter. Both the Ottoman Empire and the Soviet Empire used the threat of force, though the Soviet Union eventually did not resort to military intervention. Both Empires used blockade, thirst blockade and hunger blockade respectively, as a means to force Albania to surrender. Also, like the Ottoman Empire, the Soviet Union accused Albania of ingratitude and selling out to the West, while Khrushchev himself was seeking to compromise with his American rival.

Who is going to betray me the day after tomorrow, on the conference? [...] [Enver Hoxha] was the only one on the banquet table that kept a sullen look. Thirty coins, said Khrushchev to himself. [...] They are sold out to imperialism for thirty coins. (155)

Khrushchev had announced openly the Soviet-Albanian rupture. Newspapers published with black letters the part of his speech where he severely attacked the Central Committee of the Party, with specific stress on the phrase "the PPSH [Albanian Labor Party] leaders are sold out to the imperialism for thirty coins." (533)

Furthermore, if we examine the events which happened in Hungary, Poland and Czechoslovakia during the 1950s and 1960s, plus the trouble from Tito's Yugoslavia, we should have no problem catching the allusion of the following paragraph. Kadare skillfully conveyed the message that the Soviet Empire was not having an easy time 
to maintain its hegemony.

"These are hard time," said the intendant-in-chief. "We have many enemies to subdue. Some of them are already under our heels, but they stir and encourage on another, and are preparing to fall upon us." (127)

From what has been analyzed above, we can see clearly the theme of the two novels written by Kadare at the beginning of 1970s. The Oriental hegemonic Others constructed in the novels were to serve the political purpose in reality: to legitimize Enver Hoxha's isolation policy and to strengthen the Albanian people's national identity.

\subsection{The Insidious Other}

Sax Rohmer's novel The Mystery of Dr. Fu Manshu (1913), which was first published under the title The Insidious Dr. Fu Manchu is one of the best illustrations of how the Orient was imagined by the Westerners. The word "insidious", according to the Oxford Dictionary, has two meanings: 1. proceeding or progressing inconspicuously but harmfully; 2. treacherous, crafty. ${ }^{1}$ While agreeing with scholars such as Enis Sulstarova and Alba Cela that Kadare, under the influence of Orientalism, has presented the Ottoman Other as treacherous and barbarian, ${ }^{2}$ I would say that the word "insidious" best reflects Kadare's Orientalist mentality and the Oriental Other constructed by him in the novel The Three-Arched Bridge (1978).

The Three-Arched Bridge is written in the form of a chronicle by an Albanian Catholic priest named Gjon. Kadare offers an imagined picture of the $14^{\text {th }}$-century

\footnotetext{
1 The Concise Oxford Dictionary, ninth edition, Oxford University Press, 1995. Beijing: Foreign Language Teaching and Research Press, 1999, reprint, p. 704

${ }^{2}$ See Sulstarova, Escape from the East: Albanian Orientalism from Naim to Kadare, p. 136. Alba Cela's M.A. thesis "Orientalism in Service of Contemporary National Identity Building in Albania: The literary work of Ismail Kadare", 2006.
} 
pre-Ottoman Albania, which was under the control of a few local princes who were challenged by the decline of the Byzantine Empire and the rise of the Ottoman Empire. It is a story about events revolving around the construction of an important bridge over the river Ujana e keqe (The Wicked River) at the time of the looming Ottoman occupation. The priest claims at the very beginning that he would like to preserve what has really happened concerning the building of the bridge, because rumors had arisen and "what the people know about the bridge is no less muddled than the inventions of a madman's mind" (3).

Gjon was very concerned about the future of his country. The Ottoman tide was eventually engulfing the Balkans. "What they call the lands of Islam began a few paces in front of me," Gjon writes, "What had once been more distant than the lands of the fairy-tales was now in front of our very noses" (137). The Turks had already gained half-control of the southern Albanian naval port of Vlore and would soon control all of the Albanian territory. Some of the Albanian princes had become the Sultan's vassal, whereas Gjon's lord was still hesitating.

Gjon lived by the river, passage across which had always been by raft. For centuries, the ferry company "Boats and Rafts" had the monopoly of the transportation over the river. One day in the year 1377, a stranger fell in an epileptic fit on the riverbank, whose ravings were interpreted by a fortuneteller as a prophecy that a bridge would be built. Before long, representatives of another company named "Bridges and Roads" made their appearance, which triggered the conflict between the two companies, the road company and the ferry company.

The priest was summoned to do the interpreting work when the emissaries of "Bridges and Roads" came to visit his lord. He did not like the people from the Islam world, neither did he like their language, which according to him is "unclean" with 
odd and barbarian endings. His lord might have had the same feeling, but he didn't express that because he was in an extremely difficult financial situation and would need a huge amount of money from the road company to cure his daughter's disease. The road company did make a generous financial offer, and the prince agreed to allow the building of bridge.

Bridge-builders set up a camp, leveled the riverbanks and dug diversionary channels to allow piers to sink in the riverbed. The villagers held different attitudes toward the new object being built. Some were glad that the river would be pinned down by clasp of stone, whereas others cursed it warning that it was not easy to saddle a kicking mule. Meanwhile, some bards showed up in the region and sang new ballads composed specifically for the bridge over the Unana e Keqe, conveying the message that the water nymphs would soon retaliate against the insult done to the river.

The construction of the bridge went smoothly at the beginning but was then suddenly halted by mysterious damages done to the structure at night. While people started to associate the damage with the water spirits' anger, as had been suggested by the ballad singers, the representatives of the road company went to Gjon's liege lord and accused the ferry company for spreading the new ballad at first and afterwards destroying the bridge. The count said there was nothing he could do to help, but if what the road company had said was true, they could use the same means, i.e. with the help of legend.

Soon after this, a Turkish man, a self-claimed legend collector, came to consult the priest with regard to the Albanian legends. He was most interested in the legend of the Rozafa Castle. According to the legend, three mason brothers worked together to build a castle, but to their dismay they found that the work they did by day was 
undone by night. One day, a wise old man told them that a human being should be sacrificed in order for the castle to stand. The brothers agreed that whichever of their wives was the one to bring them lunch the next day would be immured in the castle. All three promised not to tell their wives of this decision. However, the two older brothers broke their promise. Rozafa, the wife of the faithful youngest brother, was eventually walled in the castle, with her right breast exposed to feed her newborn son, her right eye to see him, her right hand to caress him and her right foot to rock his cradle. The legend collector tended to interpret the legend in an insidious way. His various interpretations based on wickedness, betrayal and conspiracy logic made Gjon feel uncomfortable and hurt.

To Gjon's surprise, a similar ballad began to be sung in the inns of the region, and word spread that the bridge company would pay a generous reward to anyone who offered himself as a sacrifice for the bridge. One morning, a bridge worker named Murrash was found to have been immured in the pier of the bridge, with his head projecting from the wall. Rumors abounded regarding the Murrash's immurement. There were doubts that he volunteered for the reward. As far as Gjon could understand from his talks with Murrash's wife, a crime was involved in this matter, i.e. Murrash was killed by the road company rather than volunteered to sacrifice himself.

The construction of the bridge was finally completed. With Murrash immured in the wall and his protruding face plastered horribly white, nobody dared to cross the bridge. But it didn't take long for people to get used to it. The Turkish version of the bridge-building ballad became public knowledge and attracted many visitors from different lands to see the bridge. For ordinary people, the bridge is a place shrouded in mystery, but in fact it bears witness to how the Ottoman Empire gradually encroached upon Albania's territory and its national identity. 
In short, the novel is about the construction of a three-arched-bridge over an Albanian river and the manipulation of an Albanian legend by the superpowers for their respective interests. As an allegory of power struggles, it illustrates the nature of the conflict between East and West, as well as factors that affect the choice of small in-between nations like Albania. The focus of novel, though, is laid on the rising Ottoman Empire and its impact on Albania in different aspects, which, according to the priest, was leading Albania into "a long night for centuries". (183)

Lamenting Albania's fall to the Ottoman rule and the loss of its original European identity, the novel is thus replete with Orientalist discourse. The Ottoman Other is depicted by the priest as an evil threat at the very beginning.

The future looks blacker than ever before. After the chilling events at the bridge, people and the times have calmed down a little, but another evil has appeared on the horizon - the Turkish state. The shadows of its minarets are slowly falling over us. (2)

In contrast to the Ottoman Empire in The Castle, which attempted to conquer Albania through military expedition, the Ottoman Other in The Three-Arched-Bridge is depicted as insidious in nature. The insidious nature of the Ottomans is observable in their language, their music, their way of walking, their dressing style, their smile, their way of treating women, etc. i.e. in all the key aspects of their culture, even in the gesture of curse performed in the Great Royal Commination before the battle against Europe.

Everything about them throws me into anxiety, their manners, their soft gait, their hidden movements inside their loose garments that seem especially created to conceal the positions of their limbs, and above all their language, whose words, in contrast to their soporific songs, end with a crack like a mallet blow. [...] This anxiety turns into pure terror when I realize that these people are concealing a great deal. There is something deceitful in their smiles and courtesy. It is no accident that their silken garments, turbans, breeches, and robes have no straight 
line, corners, hems, or seams. Their whole costume is insubstantial, and cut so that it changes its shape continually. Among such diaphanous folds it is hard to tell whether a hand is holding a knife or a flower. But after all, how can straightforwardness be expected from a people who hide their very origins: their women? (46)

I did not conceal my amazement at the connection between this hand movement, which people and especially women make in contempt of each other, somewhat in the sense of "may my ill fortune be on your head," with the new Ottoman state policy toward Europe. (173)

Such a culture is expected to produce evil inner being and ill mentality. Indeed, the author skillfully impressed the reader with the wicked-hearted and ill-intended legend-collector, who attempted to "sling mud at everything, not sparing even the dead (96)". The priest felt insulted that their national faith in besa was misinterpreted by the collector's based on his vicious logic and morality.

Once he told me that the youngest brother had perhaps not told his wife the secret, not out of a desire to keep the besa with his brothers but because he did not love his wife and had found a way to get rid of her. Another time he suggested that perhaps the three brothers had concluded among themselves to kill the youngest wife, and the whole fiction that the walls demanded a sacrifice was just a way of justifying the murder. All his interpretations of the legend were founded on baseness, betrayal, and disloyalty. (96)

Moreover, the Ottomans are insidious because they tend to seek stealthy expansion. The purchase of the bitumen mines and the important Egnatia high way which links the East and the West was no doubt the Ottoman state behavior. But rather than admitting it openly, the Ottomans conceal their true intension. The imperialist expansion was camouflaged by private purchase behavior. Likewise, the politically motivated mobility of Ottoman people was also disguised in different ways.

They explained that their master was a rich man who had recently bought the old bitumen mines abandoned since the time 
of the Romans, and had also bought the larger part of the equally ancient great highway, which he intended to repair. He has no title, they said, he has money. (12)

Sometimes they turn up as political or commercial envoys, sometimes as trade missions, sometimes as wandering groups of musicians, adherents of religious sects, military units, or solitary eccentrics. (46)

Unfortunately, the Albanians were not aware that they were becoming victim of the Ottoman stealthy expansion. The naïve thoughts of the Albanian princes made the insidious Ottoman Other even more harmful. The kindly offered conditions by the Ottoman state lulled the Albanian princes to sleep, forgetting their old saying that "the water sleeps, the enemy doesn't'. As a result, the priest sadly pointed out, the Albanian civilization had been dragged six hundred years back before they realized that they had been kidnapped by the Ottomans.

When the count of Kashnjet and the duke of Tepelene had been the first to accept vassalage, they had mocked those who had predicted disaster. You said that the Turks would destroy us and strip us and disgrace us, they said. But we are still masters of our lands. Our castles are still where they were; our coats of arms, our honor, and our possessions are untouched.

In fact it was true in a way. The Turk did not touch them. Nothing had changed, except for something that seemed tiny and unimportant.... This was the matter of the date at the head of their letters. Instead of the year 1378, they had written "hijrah 757", according to the Islamic calendar, the adoption of which was one of the Ottomans' few demands.

They had turned time back six hundred years, and they laughed and joked. (164)

The author attributes the Albanian princes' false sense of security to the evil magic of the crescent moon used on the Ottoman flag. Of course, such a symbol with hypnotizing power must have been chosen by someone who is spiritually sinister and crafty. The priest was so worried that they were being lulled by the Ottoman moon into slumber and would soon walk toward ruin. 
When Byzantium chose the eagle, this was indeed superior to the Roman wolf, but now the new empire has chosen an emblem that rises far higher in the skies than any bird. [...] Your flesh creeps when you see it, cold, with sometimes a honey-colored and sometimes a bloody tinge. Sometimes I think that it is already bemusing us all from above. There is a danger that one day, like sleepwalkers, we will rise to walk toward our ruin. (166)

Like in The Mystery of Dr. Fu Manshu, where being remarkably intelligent is presented as one of the qualities that make Dr. Fu Manshu such an insidious Oriental, in this novel, the Ottomans, though barbarian, unfaithful and filthy, are genius in making miracle out of stones. The bridge was such a wonderful construction that even the old Ajkuna who had always cursed the bridge was stunned speechless. People looked at the miracle in awe, openmouthed.

It was incredible that this mass of men and equipment, this pig run, this gang of vagrants that had tried the patience of wood and stone, this filth, this pack of stammerers, liars, boozers, hunchbacks, baldheads, and murderers, could have given birth to this miracle in stone. (140)

As revealed by the novel, the Ottomans first appeared in the Balkan lands at the invitation of some of the Albanian princes to help quench the squabbles among themselves. But when they had to return after finishing their job, they had already been corrupted by the desire of invasion. Their eyes betrayed them and were therefore perceived by the priest as an insidious Other which pretended to be leaving but was in fact planning to come and conquer.

They are leaving us, I thought, but taking us with them. Their eyes roved covetously about, and I remembered the saying of my father Gjorg that every invasion starts in the eyes. (47)

Toward the end of the novel, the Ottomans did come back, and this time in for form of seven armed horsemen. The way how the horsemen approached gave the reader a strong sense of an insidious attack. 
Everything looked empty, when suddenly, God know how, the chill fog spawned seven horsemen. They were approaching at speed with a curious kind of gallop, not in a straight line but describing wide arcs, as if an invisible gale were driving their horses first in one direction and then in another. When they drew near enough to distinguish their helmets and breastplates, they were seen to be Turkish horsemen. (179)

The skirmish between the Turkish horsemen and the Albanian sentries guarding the bridge ended with bloodshed of one of the Turkish horsemen at the center of the bridge. The whole event looked like a mirage, but what happened was real. The priest knew that Turkish blood which stained the bridge would call back the Turkish army and soon the Albanian mountains and plains would be flattened, whereas everything would turn savage, under the crescent moon.

Under that moonlight, I saw whole plains awash with blood, and mountain ranges burned to ash, I saw Ottoman hordes flattening the world and the ash and the scorched remains of men and their chronicles. And our music, and dances, and costume, and our majestic language, harried by that terrible "-luk", like a reptile's tail, seeking refuge in the mountains among the lightning and the beasts, which will turn it savage. And below the mountains, I saw the plains left without speech. And above all I saw the long night coming in hours, for centuries ... (183)

All in all, by exposing the conspiracy behind the construction of a new bridge and the subtle build-up to military invasion, Kadare presents the Ottoman Empire as an insidious Oriental Other. Orientalist discourse permeates the whole book. The shadow of their minarets, their babble-like language, their soporific songs like "hashish dissolved in the air" (149), their shapeless garments with no straight lines, their evil curse with contemptible gesture, their interpretations of the Albanian legend "founded on baseness, betrayal, and disloyalty", as well as their stealthy expansion, their crafty offer to the Albanian princes, their ominous crescent moon, their covetous eyes, etc. point to the insidious nature of the Ottomans and match perfectly the features of the Oriental Ottoman in the Westerners' imagination. 


\subsection{The Totalitarian Other}

Totalitarian rule refers to the political system where the state holds total authority over the society and keeps under its control all aspects of social life (Conquest 74). ${ }^{1}$ The concept of totalitarianism bore positive sense when it was developed by the Italian fascists back in the 1920s. However, during and after the cold war, it became a prominent political discourse the West uses for its anti-communist purpose. In 1949, the English novelist George Orwell published his most influential work Nineteen Eighty-Four, for which ever since then the term "Orwellian" has been widely used to refer to totalitarianism or authoritarianism. ${ }^{2}$

Kadare has often been compared to George Orwell for his skillful writing against totalitarian regime. Many of his books, such a s Concert (1988), Agamemnon's Daughter (2003), The Successor (2003), etc. impressed readers with the devastating accounts of the mental and spiritual contamination wreaked on the individual by the totalitarian state. But it is in The Palace of Dreams (1981) and The Pyramid (1992) where Kadare most successfully unmasked the nature of the totalitarian rule and the secret of how a totalitarian regime survives. The former, in particular, is considered by most critics as comparable to Orwell's Nineteen Eighty-Four. Like the Ministry of Truth in Orwell's novel, the Palace of Dreams or Tabir Sarrail presented by Kadare is a powerful state institution in control of people's subconscious mind. The anti-totalitarian theme was also confirmed by Kadare himself in his memoir Albanian Spring, where he refers to The Palace of Dreams as "the novel which launched the most ferocious attack on the dictatorship" (8).

The Palace of Dreams is set in a fictive version of the nineteenth-century Istanbul,

\footnotetext{
${ }^{1}$ Robert Conquest, Reflections on a Ravaged Century, New York: W. W. Norton \& Company, 2000, p.74.

${ }^{2}$ George Orwell, Nineteen Eighty-Four. Fairfield, Iowa: 1st World Publishing, 2004.
} 
with its central invention being a huge state institution devoted to analyzing the dreams of the Ottoman Empire's subjects in search of the crucial Master-Dreams which involve the security of the Empire and of the Sovereign. The protagonist Mark-Alem was a member of the powerful Quprili family. Their ancestor was the Albanian priest Gjon, who renamed himself as Quprili (from the Turkish word "köprü" which means bridge) after having recorded in the form of a chronicle the construction history of the three-arched bridge over the river of Ujana e Keqe back in the $14^{\text {th }}$ century. ${ }^{1}$ The Quprilis had lived for generations in the capital of the Ottoman Empire and had produced many viziers, government officials and bureaucrats in service of the Sultan. They were assimilated Ottomans and to them ethnic origin was of secondary importance, i.e. power and prestige took priority over ethnicity.

The novel begins with Mar-Alem's first day to his new work place, the Palace of Dreams or Tabir Sarrail where dreams collected from all over the Empire, sorted and interpreted in terms of their value for the state security. With the recommendation letter from his uncle, the Vizier, he was placed directly into the selection department, a crucial section where all the dreams are sorted into two categories: useful and useless. It was in the selection department that he first met the dream in which there were a bridge, a bull, a musical instrument and a waste land. After a second thought, he put it into the useful ones. Mark-Alem was quickly transferred to the most important section of the Palace, the interpretation department, where he met again the weird dream and labeled it as un-interpretable. For both appointments, he was told "You suit us" $(21,68)$. Indeed, all this was arranged by his Vizier uncle, who warned

\footnotetext{
${ }^{1}$ Kadare links The Palace of Dreams with The Three-Arched Bridge by claiming the narrator-priest Gjon to be the ancestor of the Quprils family. Gjon's anxiety on the eve of the Ottoman conquest, his re-identification by adopting a new surname and his descendants' high position within the Ottoman power structure point us to the treachery of the upper class Albanians who chose to sacrifice their national interest to ensure their own interest. In the text, Kadare makes this clear through the Albanian populace's contemptuous attitude toward the Quprilis' preference of Ottoman assimilation to ethnic identity. From this point of view, the novel can be seen also as supportive of Enver Hoxha's policy: Albanians must fight against the foreign enemies as well as the enemies from within.
} 
Mark-Alem to be cautious about the potential attacks on their family by means of fabricated dreams. As a novice, Mark-Alem was overwhelmed by all that much to learn and didn't realize that he let pass the dream which finally became the Master-Dream and struck a heavy blow on his family.

Mark-Alem's younger uncle Kurt was the one who awoke his consciousness of their family's ethnic identity. For generations the Quprili family kept the tradition of inviting the Bosnian bards to sing and celebrate their glorious family history. Kurt, however, broke the tradition by inviting the Albanians bards. This was a politically significant event, because it implied that the Quprilis were dropping their Muslim religion for their Albanian ethnicity as the paramount identification. At the time when all the Balkan Orthodox nations, including the Greeks, the Serbs, the Bulgarians and the Romanians, were fight for their independence, the Muslim Albanians' identification on the basis of their ethnicity was a viewed by the Ottoman Sultan as a dangerous signal to the complete disintegration of the Empire. The dream Mark-Alem was not able to interpret was interpreted by others as the Quprili family siding with the nationalist Albanians who had been stirred up by the folk music instrument Lahuta, which represented the Albanian culture and spirit. Therefore actions were taken according to the dream. The Albanian rhapsodists were killed and Kurt was arrested. The Vizier reacted immediately to the disaster by asking for help from foreign countries such as Austria. The novel ends with Quprili family's maintenance of its power within the Ottoman Empire, at the price of sacrificing Kurt's life to demonstrate their loyalty to the Sultan.

The singing of the Albanian rhapsodists had an immense impact on Mark-Alem. The sound coming out of the musical instrument Lahuta exerted a powerful magic on him. "Suddenly it was revealed to Mark-Alem that this hollow cage was the breast 
containing the soul of the nation to which he belonged" (151). Nevertheless, in order to save his family and himself, he must compromise. He was finally promoted to the position of the director of the Palace of Dreams, with his inner world struggling between his imperialistic Ottoman identity and his ethnic Albanian identity.

Judging from the historical background of the novel and the story plot, the theme of ethnic identity is more than evident. By portraying the compromising Quprilis as negative figures who betrayed the Albanian nation for their own family interest, the novel serves as an admonition to the ethnic Kosovo Albanians who were serving in the Yugoslavian power structure. This political message can be easily caught if the reader takes into consideration of the political situation in Kosovo during the early 1980s. On the other side, however, the novel is also featured with an accentuated allegory of the totalitarian rule. As confirmed also by Kadare himself in his memoir Albanian Spring, the novel "launched the most ferocious attack on the dictatorship" (8). Even Noel Malcolm who often questions Kadare's accounts of his relationship with Enver Hoxha's regime admits that "No one who reads The Palace of Dreams, one of Kadare's greatest works, could possibly accept the dismissive judgment of him as a party hack". ("In the Palace of Nightmares", 24)

The attack on Hoxha's dictatorship is hidden but perceivable throughout the novel. At the very beginning of the novel, we are presented with people hurrying to work in gloomy climate, and the protagonist feeling cold and dangerous.

It was a wet morning, with a light sleet falling. [...] As usual at this hour of the day the avenue was full of clerks from the ministries hurrying to get to their offices on time. [...] Someone in front of him skidded on the pavement. [...] Keep your eyes open! Mark-Alem said inwardly, not quite sure if he was warning the stranger or himself. (10)

He'd already turned up his fur collar, but now involuntarily made as if to turn it up again. In fact, though, it wasn't his neck that was cold, but a specific place in his chest. (10) 
It is certainly abnormal for a young man to start a new job in such a low spirit, with no slight excitement and delight. However, any Albanian who lived under Hoxha's dictatorship would not fail to find this gruesome atmosphere familiar and see the analogy between the Palace of Dreams and the Albanian Ministry of Interior Affairs or even the Albanian Labor Party's Central Committee itself. As has been pointed by Kastriot Myftaraj, the way from Mark Alem's residence to the Palace of Dreams shares much similarity with the way from Kadare's apartment to the Central Committee (238). ${ }^{1}$ The formidable buildings which made Mark-Alem feel repressed are purposefully described to refer to the key state institutions in reality, such as the Central Committee, the Interior Ministry, the Foreign Ministry, etc. The terror emanating from the buildings and the totalitarian state mechanism caused anxiety and fear among people.

The tall building, looking down on the bustle in the streets with their heavy doors and wickets still shut, seemed to add the gloom. [...] He felt a cold shudder run down his spine. (9)

Yes, here was the entrance to the Palace. Its two wings stretched away into the mist, while the main part of the building stood back a little as if recoiling from some threat. Mark-Alem felt his anxiety increase. (11)

The power of the Palace of Dreams consists in the ruler's grip of the subconscious world of its subjects. In The Concert (1988), Kadare told the story of how Mao Zedong's regime "planted" bugs everywhere to detect what people really thought in mind but didn't dare to tell in public. The Albanian intelligence service Sigurimi (Albanian word for security) was also the most effective state apparatus used by Hoxha's regime. People were encouraged to report to the government other

\footnotetext{
${ }^{1}$ Kastriot Myftaraj, "Kodi sekret i romanit të Ismail Kadare <Pallati i ëndrrave>” (The Secret Code of I. Kadare's novel The Palace of Dreams) in Gjyqi intelektual i Kadaresë (The intellectual court of Kadare), Prishtinë: Buzuku, 2008. pp. 238-246.
} 
people's secret thoughts or private remarks. ${ }^{1}$ Under Hoxha's totalitarian rule, Albanians had to be cautious about what they say even to their family members. It was not rare that neighbors or good friends turned out to spies. The secret police was everywhere, watching the last space of people's privacy. In Kadare's Palace of Dreams, the account of the role of the Sultan's Palace of Dreams clearly alludes to the task of the Albanian secret intelligence service Sigurimi.

The task of our Palace of Dreams, which was created directly by the reigning Sultan, is to classify and examine not the isolated dreams of certain individuals [...] but the 'Tabir' as a whole: in other words, all the dreams of all citizens without exception. For the interpretation of that dream, [...], may help to save the country or its Sovereign from disaster; may help to avert war or plague or to create new ideas. So the Palace of Dreams is no mere whim or fancy; it is one of the pillars of the State. It is here, better than in any surveys, statements, or reports compiled by inspectors, policemen or governors of pashaliks, that the true state of the Empire may be assessed. For in the nocturnal realm of sleep are to be found both the light and the darkness of humanity, its honey and its poison, its greatness and its vulnerability. [...] Every passion or wicked thought, every affliction or crime, every rebellion or catastrophe necessarily casts its shadow long before it manifests itself in real life. (19-20, italic emphasis mine)

The vital importance of the Palace of Dreams, i.e. Hoxha's secret police, is overtly pointed out by Mark-Alem's Vizier uncle when he said "whoever controls the Palace of Dreams possesses the keys to the State" (113). Therefore rivalry has been inevitable between influential forces in their struggle for gaining the control of the Palace of Dreams. As the Vizier explained, "The Tabir Sarrail was under the influence of the banks and the owners of the copper mines, whereas more recently it has grown closer to the Sheik-ul-Islam faction" (113). The important role of the Palace was also emphasized by Mark-Alem's boss on his first day to work.

\footnotetext{
${ }^{1}$ That is one of the reasons why there was such a heated debate after the 1990s as to whether the dossiers of the archives should be allowed to open. There were concerns that reopening the files would turn some of family members, neighbors, friends into enemies and thus causing more social problems.
} 
The world has long recognized the importance of dreams, and the role they play in anticipating the fates of countries and of the people who govern them. [...] Old books tell [...] Now this long tradition undoubtedly has its own importance, but it pales into insignificance beside the operations of the Tabir Sarrail. Our imperial State is the first in the history of the whole world to have institutionalized the interpretation of dreams, and so to have brought it to such a high degree of perfection.

In this way, Kadare wanted to show that Albania was under complete control of Hoxha's regime, which reached the highest level of totalitarianism in his rule. Kurt, who saw the Palace of Dreams as "the oldest State institutions" and also, "despite its charming name, one of the most formidable" and "the most absurd institution in the whole Empire (55-57)", denounced the dream interpretation institution.

"In the other ones the terror's obvious. The fear they inspire can be seen for miles, like a cloud of black smoke. But with the Tabir Sarrail it's quite different". Kurt said. (56)

Of all the mechanisms of State the Palace of Dreams is the most remote from human will. [...] It's the most impersonal, the blindest, the most deadly, and so the most autocratic. (56)

Through Kurt's mouth, Kadare further disclosed the nature of the Palace. The masses are not only victims of totalitarianism, but also accomplices, though unconsciously and imposed by the mechanism of Tabir Sarrail.

In my opinion, it's the only organization in the State where the darker side of its subjects' consciousness enters into direct contact with the State itself. (56)

"The masses don't rule, of course," he continued, but they do possess a mechanism through which they influence all the State's affairs, including its crimes. And that mechanism is the Tabir Sarrail." (56)

Mark-Alem is exactly such a character, a victim and an accomplice of totalitarianism at the same time. He felt constantly perplexed by two contradictory feelings, enjoying the priority of being an employee of the Palace of Dreams and 
meanwhile suffering the indifference, suffocation, cold and danger within the totalitarian system.

Mark-Alem had reached the top of the stairs and was now going along the long corridor together with dozens of his fellow-workers, who disappeared in small groups through the various doors. The closer he got to the Interpretation rooms the more the temporary sense of self-assurance he'd had in the cafeteria faded away, as it usually does when it derives from someone else's sycophancy. In its place came the feeling of suffocation that descended on him at the thought of becoming once again an insignificant clerk in the heart of gigantic mechanism. (84)

Even though the big tiled stoves were filled with coal and lit first thing in the morning, the Interpretation rooms were freezing. Sometimes Mark-Alem kept his overcoat on. He couldn't understand where such extreme cold came from. "It comes from the files - the same place as all our troubles come from." said someone he was having coffee with in the cafeteria one day. Mar-Alem walked away without answering. Afterwards he thought the man might have been a provocateur. Every day he was more convinced that the Tabir Sarrail was full of strange people and secrets of every kind. (84-85)

Mark-Alem learned that thousands of Tabr Sarrail offices were scattered all over the vast empire to collect dreams, which means that the palpuses of the totalitarian monster reached every corner of the country. Once the master-dream was chosen, the dreamer would be summoned to the capital for inquiry. He was shocked and furious when he saw the dreamer of the master dream being carried out in coffin. Apparently, the death of the master-dream dreamers refers to the persecution of those who dreamed differently from the regime. In other words, under Hoxha's totalitarian rule, those who dreamed of Westernization, of the rapprochement with Yugoslavia or Soviet Union, etc. were purged and annihilated because they were considered dangerous elements to the state security.

As he went up the stairs he was filled with ever-increasing anguish. He'd often thought of the unfortunate dreamer, but he'd never thought he'd end up like this! [...] was it decreed in 
advance that whoever was summoned to the Tabir Sarrail must meet with a similar end? Monstrous! he thought, surprised at his own sudden indignation. You're not satisfied with all the rest that you destroy - you have to devour human beings aw well! (91-92)

On his first day off, Mark-Alem found himself alienated from the real world. He was appalled by the effect of the world of dreams on him.

He looked at the city like someone returned from a brief exile. By now not only the sky struck him as washed out and insipid, but also all the rest - the walls, the roofs, the carriages and the trees. [...] He had an icy sensation in his chest. [...] What had happened, then, to life, to mankind, to everything here below? (107)

As an employee of the Palace of Dreams, Mark-Alem suffered from strong anguish of getting lost and struggled hard to keep sober-minded. The novel repeatedly describes the Palace as a labyrinth, the labyrinth of Jorge Luis Borges, and Mark-Alem's fear of being unable to get out of the endless and identical corridors.

Mark-Alem mended his pace so as to get to the circular corridor as fast as possible, but it still didn't appear. The further he went the more lost he felt. What if he collapsed and lost consciousness in these empty corridors? Again he felt his eyelids growing heavy. Why on earth did I ever come down here? he asked himself. He began to walk so fast he was almost running. The sound of his own footsteps, multiplied by the echo, increased his terror. I will not go to sleep! he told himself. No I won't fall into your trap! (137)

Unfortunately, Mark-Alem finally fell into the trap and surrendered to the totalitarianism. He became the director of the Palace of Dreams and servant of the dictatorship for exchange of social priority.

As days went by he grew more and more conscious of the importance of his new post. He now had a sky-blue carriage at his disposal, waiting for him outside the Palace, and he felt it was not merely his equipage but he himself who commanded respect, silence and fear. He was tempted to smile at this, finding it almost incredible that he, recently so fearful about the mystery of the State and the oppressive atmosphere emanating 
from its organs, should now cause the same apprehension in others. (178)

Being the director of the Palace of Dreams, Mark-Alem saw the power of the institution over the high officials. No one, except the dictator himself, could be exempt from the menace of insecurity within the totalitarian system.

In the Assistant Minister's eyes, as in those of all the other senior officials, there was, despite their polite smiles, a constant query: Is there a dream about me? ... Being powerful and laden with honors, holding important posts and enjoying influential support - all this was not enough to reassure them. What mattered was not merely what they were in life: equally important was the part they played in other people's dreams. (183)

Toward the end of the novel, Mark-Alem was presented as being caught as a hostage by the regime. He had to couch in the refuge of the Palace to protect himself and his family. No matter how powerful he might seem as the director of the Palace of Dreams, he was merely a high-rank employee in service of and under the control of the despotism.

He felt that if he was crouching there it was to protect himself, and that if ever, some late afternoon like this, he gave in to the call of life and left his refuge, the spell would be broken: the wind would turn against the Quprilis and the men would come for him as they'd come for Kurt, and take him, perhaps a little less unceremoniously, to the place from which there is no returning. (190)

As can be seen from the above, the novel unfolds through gripping narrative an extensive panorama of the all-controlling dictatorship which monitors even the subconscious world of its subjects. By means of tense allegory, the novel is abundant with a powerful anti-totalitarian discourse. Kadare spared no effort to disclose the macabre nature of totalitarianism, the crimes committed under this system, and voluntary or involuntary involvement of all the subjects in maintaining the dictatorship. In finding the roots of the despotism, Kadare traced back to the 
immemorial depths of the Oriental civilization.

The Vizier went on, explaining that [...] Tabir launched ideas, and its own strange mechanism immediately endowed them with a sinister power, for they were drawn, according to him, from the immemorial depths of Ottoman civilization. (115)

After the fall of communism, the totalitarian Other with Oriental origin became the theme of Kadare's another work entitled The Pyramid (1992). Though lacking much of the density and mystery of Kadare's earlier meditation on the totalitarian state when he felt psychologically suppressed under the communist regime, The Pyramid nevertheless turned out to be a successful anti-totalitarian parable. ${ }^{1}$ Set in the ancient Egypt, it takes the building of the Pyramid of Cheops as an example of how rulers impose toil and pain on their people in order to maintain their absolute power. In the form of a historical novel, The Pyramid is an exploration of the horror of untrammeled state power.

At the very outset of the novel, the newly-enthroned Pharaoh Cheops announces that he would forgo the construction of a pyramid in his honor. Alarmed by Cheops's intention of breaking the old tradition, the court sages resorted to the chronicles in the archives to explain to the Pharaoh the origin and the role of the pyramid: it was constructed in crisis caused by prosperity, with the purpose of "keep[ing] folk busy night and day so that they became oblivious", because "prosperity, by making people more independent and freer in their minds, also made them more resistant to authority in general and to the power of the Pharaoh in particular" (9). The Pharaoh was told that the pyramid is not a tomb but "the pillar that holds power aloft" (10).

In the first place, Majesty, a pyramid is power. It is repression, force, and wealth. But it is just as much domination of the rabble; the narrowing of its mind; the weakening of its will; monotony;

\footnotetext{
1 The name of the book suggests that Kadare got his inspiration from the pyramid-shaped Enver Hoxha Memorial Museum in the center of Tirana. The Museum was designed by Enver Hoxha's daughter and opened in 1988. Now the 17,000 meters square complex awaits demolishment and the new Albanian parliament will be built on its site.
} 
and waste. O my Pharaoh, it is your most reliable guardian. Your secret police. Your army. Your fleet. Your harem. The higher it is, the tinier your subjects will seem. And the smaller your subjects, the more you rise, O Majesty, to your full height. (10)

And so decision was made to build the greatest pyramid ever. The project took 20 years, obsessing and oppressing the entire country. Even the High Priest and other high court officials who convinced the Pharaoh to build the pyramid were arrested by the Pharaoh's secret police. The generation-long construction of the pyramid was measured not in weeks or years but in numbered stones, and in the millions of gruesome, unnecessary deaths. Each of its tens of thousands of stones claimed dozens of men's lives. Conspiracies were rumored so that to necessitate purges and tortures. Finally, after consuming all Egypt, the monster swallowed the body of Cheops himself, making the Pharaoh the crowning victim of pyramid, the symbol of absolute power. Sadly and ironically, Cheops sighed that "With my own hands I have prepared my own annihilation" (117).

The novel is a haunting meditation on political despotism. Kadare is familiar with this theme because of his experience in the totalitarian communist Albania. Like The Palace of Dreams, the novel is imbued with spiritual terror, the horrible physical annihilation of the subjects ruled by the absolute sovereign, as well as the perceivable existence of the secret police. Hundreds of thousands were conscripted for the work of construction. The fate of the so called the "dead men" is especially heart-wrenching. The time when the pyramid was completed, they would be murdered so that the pyramid's inner structure would remain forever a secret. That is the price for keeping the top secret of the totalitarian ruler, the blood of numerous innocent people sacrificed and sucked by the earth.

The "dead men", as the inside workers were called, suffered 
from incessant migraines. They pretended that they did not know the secret of the false sliding doors, nor of the ones believed to be real [...] When they emerged pasty-faced on the last day of their work, and saw the soldiers waiting for them outside with axes in their hands, they understood how pointless had been all their meandering in the pyramid's inner labyrinths, all their cunning, all their deceptions and their feigned gullibility at the sight of false doors, or of real ones that led to dummy passages, and so on. They finally realized that their fate had been sealed twenty years earlier. (109)

People had expected blood to flow from the vertex because of the pyramidion scratching the sky, but instead it welled up at the foot of the mountain of the stones. (110)

The people were so much perturbed by the secret police that they thought the construction work would never end. So when news broke that the pyramid construction was finished, the inhabitants of the capital were dumbfounded and couldn't believe their ears. Other than physical toil and torture, the miserable people suffered psychological torment.

"You said the investigation was finished?"

"No, not the investigation, old chap, the pyramid!"

"Oh, that pyramid ..."

The dirt of quite a different kind of construction was still on their backs; their ears were still full of the echoes of relentless interrogations: You maintain that you never were on row eighty-one? that you said nothing to the hauliers of stone number fifteen hundred and two? But why don't you confess? We know it all anyway! As a result, for a long while few people had cared very much about what was going on on the ground at Giza. (107)

Ten of the "dead men" were selected as the reprieved whose task was to open the secret passages on the day the Pharaoh's body would be laid to rest in the pyramid. The way they themselves and their families were treated is incredibly macabre and inhumane, something that could only happen in a totalitarian and tyrannical state.

In place of invitations to the celebration dinner, the families of 
the reprieved received their relative's excised tongues. [...] the organs came wrapped in a pypyrus bearing the pharaonic emblem. Nobody failed to appreciate that what had been sent out was another warning. (112)

Ironically, the Pharaoh finally realized that he himself became a victim of the pyramid. It was only till that moment that he contemplated in retrospect the construction of pyramid with a sense of remorse.

He had had people punished on charges of delaying the building work. Then he had had others sentenced for the opposite reason, because they had speeded the work up. Then again for the first reason. And thereafter for no reason at all. (116)

Unlike The Palace of Dreams, The Pyramid does not have a conventional plot and protagonist. Rather, the characters are only pop-ups. It emphasizes the dictator's paranoia, arbitrariness and doomed fate of falling victim to his own absolute power, which made the novel political comedy. But in general, like The Palace of Dreams, it is an extended, multi-faceted parable of life in Albania under the communist dictatorship. The two novels represent Kadare's haunting meditation on the matter-of-fact brutality of political despotism, and his negation of the communist rule era in Albania, depicting it as the totalitarian Other that should be rejected by the Albanian nation.

\subsection{Discussion}

As the well-known Albanian studies scholar Robert Elsie has pointed out, “Kadare's works have at all times been a strict reflection of the vicissitudes of Albanian political life" (1991: 260). ${ }^{1}$ Through his works analyzed in this chapter, we can see how the Oriental Other is constructed to serve political purposes. During the

\footnotetext{
${ }^{1}$ See Elsie Robert, "Evolution and Revolution in Modern Albanian Literature", World Literature Today, vol. 65, issue 2, 1991: 256-263.
} 
Albanian communist rule, Albania allied itself successively with Belgrade, Moscow and Beijing and broke one after another with these countries. Kadare is the only writer who has created so many influential works with regard to the most important events in the contemporary Albanian diplomacy. His works do not only reflect Albania's diplomatic oscillations over the past half a century, but also mirror the political struggles within Albania, as well as the change of political order on the international arena.

The Castle (1970) is Kadare's first influential literary creation by which Kadare attempted to reflect the Soviet-Albanian relationship in an allusive way. Hoxha's refusal to follow Khrushchev's ideology introduced a period of Albania's political and cultural isolation in the 1960s. In late 1960s, USSR was at the peak of its development and was coming "close to gaining the upper hand in the East-West confrontation" (Skoug 245). ${ }^{1}$ The Soviet invasion of Czechoslovakia in 1968 strengthened Hoxha's vigilance against any potential military attack from Soviet Union. Within Albania, Hoxha's isolationism needed propagandistic support. Thus the Skanderbeg myth of fighting against the mighty Sultan army was utilized to justify Hoxha's isolationist policy, to glorify his heroism against the hegemonic Soviet Union, and to unify people around the Party. It was also at that time that hundreds of thousands small castles, i.e. bunkers, started to be built all across Albania. The Castle was written under such political circumstances. It was welcomed by the government for its supportive role. Nowadays, some people attempt to interpret the novel as an ironic work against Enver Hoxha's isolationism. The renaming of The Castle into The Siege implies such an attempt to manipulate the originally conveyed message. However, even if the pro-Hoxha purpose can be downplayed, the Oriental

\footnotetext{
${ }^{1}$ Kenneth N. Skoug Jr., Czechoslovakia's Lost Fight for Freedom 1967-1969: An American Embassy Perspective. Westport, CT: Praeger Publishers, 1999.
} 
Other constructed in the novel stays there untouched, telling us stories about the invading Ottomans and the alluded hegemonic power.

The Three-Arched Bridge (1978) is analyzed mainly from the perspective of an insidious Oriental Other. But apart from the Orientalist discourse, the novel masterly reflects the complicated world political situation of the 1970s. Trapped in Vietnam War, the United States was encountering a rather difficult situation in competing against the USSR. In order to win balance, it sent friendly signals to China, which was also interested in a US-China detente. Albania reacted violently against China's new political orientation, reiterating its determination to stick to the Orthodox Marxism-Leninism and repudiating China's new revisionism. In 1978, when China cut all its financial aid to Albania, Hoxha's regime fell into a severe situation. Nevertheless it held tight the so called genuine Marxism. The story of how the medieval Albania caught between the Western crocodile and Eastern tiger lost its independence justifies Albania's constitutional amendment in 1976 that no foreign financial loan should be accepted. In other words, though The Three-Arched Bridge depicted on the surface an insidious Ottoman Other, it is in essence a reflection of the US-Soviet rivalry in 1970s for economic and strategic supremacy over the in-between countries.

It is unquestionable that The Palace of Dreams (1981) was also written with an allusion to the international political situation. ${ }^{1}$ In the early $1980 \mathrm{~s}$, while the USA was recovering from the Vietnam War, USSR fell into the trouble of launching the Afghanistan War. As noted by Stephen Sestanovich in his paper "Did the West undo the East", the economic stagnation and the huge military expenses of the USSR in 1970s, plus its agreement in 1975 to treat human rights as a principle of East-West

\footnotetext{
${ }^{1}$ It would be logical to assume that Kadare's The Palace of Dreams was written with Enver Hoxha's consent. Otherwise, Kadare would not have been able to survive after the publication of his almost blatant attack on the totalitarianism.
} 
relations ${ }^{1}$, contributed most importantly to its disaster in late $1980 \mathrm{~s}^{2}{ }^{2}$ The Solidarity Movement in Poland indicates the emergence of centrifugal forces in early 1980s within the Eastern Bloc. The Soviet incompetence to control the situation in Poland signaled that the hegemonic USSR was stepping on its way of decline. The United States certainly played a role in stirring up the rebellious sentiments among USSR's satellite countries and the Soviet republics. ${ }^{3}$ At the same time, Tito's death in 1980 lifted off the lid that had covered the nationalist sentiments of the Yugoslavian nationalities. The Socialist Federal Republic of Yugoslavia, having the same ethnofederalism as the USSR, was also a victim to nationalism (Beissinger, 331). ${ }^{4}$ In Kosovo, where ethnic Albanians comprised the majority of the population, the massive demonstrations in March 1981 signaled the start of open nationalist conflicts in Yugoslavia. The Palace of Dreams is a reflection of the international politics, where the declining Ottoman Empire can be interpreted as the Soviet Union or the Eastern Bloc, which was alarmed by America's attempts to stir up anti-Soviet feelings of its subject peoples. The United States, like Austria in The Palace of Dreams which encouraged the Albanians to give priority to their ethnic identity and establish their national state rather than stay under the Ottoman rule, played an important role in the dissolution of the USSR. Additionally, the novel can be interpreted also as a message from Albania to the Kosovo Albanian leaders that it was time to show their due ethnic allegiance. As Kastriot Myftaraj has pointed out, the West saw Albania, on the one hand, as the weakest link in the international communist chain to be broken off, and on the other hand, an important role in the disintegration of Yugoslavia by exerting its

\footnotetext{
1 Thirty-five European nations, including the United States and the Soviet Union, signed the Helsinki Final Act of the Conference on Security and Co-operation in Europe on August 1, 1975. Albania refused to sign the act.

2 Stephen Sestanovich, "Did the West undo the East", The National Interest, 31(Spring 1993): 26.

${ }^{3}$ For America's support to Walesa and his Solidarity Movement, please see pp. 218-222 in John Lewis Gaddis, The Cold War, A New History, New York: The Penguin Press, 2005.

4 Mark Beissinger, "Nationalism and the Collapse of Soviet Communism", Contemporary European History, vol. 18, Special Issue 03, August 2009, pp 331-347.
} 
influence on the massive Kosovo Albanian population (241). ${ }^{1}$

Kadare is a master of using history as a coat to camouflage his works of contemporary political themes. The Castle, The Three-Arched Bridge and The Palace of Dreams are all set in the historical background of the Ottoman Empire, the two former ones in its rising period and the latter in its declining period, alluding respectively to the hegemonic USSR toward Albania in the early 1960s, the rivalry between the USSR and the USA in the 1970s and 1980s, and the USSR threatened by the stirred up nationalist sentiments among its republics and satellite countries in the early 1980s. Though the Ottoman Empire was depicted in the novels as the Oriental Other of Albanian nation, no Albanian reader could be unaware of the analogy construed between the Sublime Porte and the Kremlin.

However, Kadare is not confined to setting his novel in a historical background. He also addressed directly the contemporary political problems. In The Great Winter Kadare treated the break between Albania and the Soviet Union, portraying Enver Hoxha as a national hero like Skanderbeg and Khrushchev as the arrogant hegemonic Other. In The Concert (1988) Kadare portrayed China as an insidious Far Oriental Other, a potential danger to the "comprehensible" West.

China will always be an enigma. Zhou Enlai once said that if you want to understand Chinese politics you should go and see the Peking Theatre ... But that's full of incomprehensible symbols, monkeys, and snakes and dragons ... ! (19)

Kadare laments Albania's unfortunate binding to the "evil" China due to their common anti-Sovietism. Through the inner celebration of the Albanian writer Skender when he heard Chairman Mao was dying, Kadare exclaimed his cheer that Albania was eventually getting rid of the Far Eastern Other.

\footnotetext{
${ }^{1}$ Kastriot Myftaraj, "Kodi sekret i romanit të Ismail Kadare <Pallati i ëndrrave>" (The Secret Code of I. Kadare's novel The Palace of Dreams) in Gjyqi intelektual i Kadaresë (The intellectual court of Kadare), Prishtinë: Buzuku, 2008. pp. 238-246.
} 
It was the moment of parting from evil, certainly. The omens foretold a farewell to suffering. The pain which history had inflicted on Albania at the end of the present millennium was about to end. [...] Asia had bestowed a final kiss. (321)

With its overt criticism of the depersonalization of the individual under Chinese communism, The Concert served the political purpose in the 1980s: denunciation of the totalitarian communist system.

After the collapse of the communist regime in Albania in 1992, Kadare published The Pyramid, which was dedicated specifically to the accusation of totalitarianism. Being set in the ancient Egyptian background, the novel has in fact political meaning for the reality. Reading The Pyramid, no Albanian could draw away his mind from Hoxha's Mausoleum in a pyramid-shaped building in the center of Tirana. Though pyramid was viewed as a symbol of power in the novel, it is after all a building which buries the autocratic ruler. This novel undoubtedly marks the end of Hoxha's totalitarian rule.

As we can see, most of Kadare's major works between 1970s and 1990s deal with the Oriental Other. Portrayed as hegemonic, insidious and totalitarian, it can be found in the Ottoman Empire, the ancient Egypt, the Soviet Union and China. Camouflaged in historical narration, the novels serve contemporary political purposes and reflect the political situation of a specific time. Albania is portrayed as the victim of the Oriental Other. It was invaded and ruled for centuries by the barbarian Ottoman Other and thus deprived of the right of industrialization. It was bullied and threatened by the hegemonic Soviet Union. Also it was unfortunately linked to the evil Far Oriental China and imposed with totalitarianism. Anyway, according to Kadare, the identification with the Orient was a total disaster for the Albanian nation. Evil, barbarianism, despotism and so on all had its origin in the Oriental civilization and Albania should keep away from the Oriental Other. 
Finally, it should be noted that Kadare's works are multi-faceted and they can be given multiple interpretations. It's hard to say which approach is absolutely right and effective in deciphering the subtext and the metaphors of his works. For the convenience of analysis, the dissertation has shown only one/two of Kadare's representative works that epitomize a specific attribute of the Oriental Other. For example, The Three-Arched Bridge was analyzed in terms of the insidious character of the Oriental Other. But this doesn't mean that the novel is confined to such a theme. Other Oriental aspects such as barbarianism, obscurantism, savagism etc. can also be found in the novel. Not only that, as a work to support Hoxha's self-reliance policy, the novel also presents in a realist approach the Western Other in rivalry with the Oriental Other, as well as the internal Other, i.e. the Albanian ruling class who sold out the sovereignty for their own interests. The fight between the Western crocodile and the Oriental tiger is a superb design that indicates the author's in-depth appreciation of political realism, the dominant international relations theory during the Cold War. Likewise, in The Great Winter, the Soviet Union, apart from its hegemonic character, was also depicted as barbarian, with the odd endings of "-ov", "-ski" etc. at the end of their names, a parallel to the Turkish barbarian ending of "-llah", "-th", "-luk", etc. as ironically mocked in The Three-Arched Bridge. Moreover, parallel to the major theme, the Internal Other represented by those who dreamed of Albania's Westernization occupies a significant proportion of the novel. Therefore, Shaban Sinani has pointed out in his classification of Kadare's works, the same novel can be classified into different cycles, for example, The Castle can be put in the historical cycle, in the mythological cycle, and to some extent in the imperial cycle $(93)^{1}$. The novels analyzed in this dissertation are overlapping in terms of the

\footnotetext{
${ }^{1}$ Shaban Sinani, Letërsia në totalitarizëm dhe dossier K. (Literature under totalitarianism and the file on K.), Tirana: Naimi, 2011.
} 
Other they present. The Oriental Other presented in the novels analyzed in this chapter may also contain other important themes or messages, depending on the political background of the novel's publication.

All in all, following the rule stated in Orwell's Nineteen Eighty-Four that "Who controls the past controls the future; who controls the present controls the past" $(46)^{1}$ the Hoxha regime made tremendous efforts in controlling the past history and the present discourse. To strengthen his rule and to justify his isolation policy, Hoxha used literature as an effective means to control people's mind. Voluntarily or involuntarily, Kadare served Hoxha's regime and produced numerous works where the Oriental Others of the Albanian nation were invented to refer to the Ottoman Empire, the Soviet Union or China. These historical or contemporary Oriental Others are held responsible for Albania's backwardness and political instability. Though Kadare started to doubt the totalitarian system in 1970s and subtly denounced the traumatic effect of totalitarianism on people, as he did in Palace of Dreams (1981), it is after the collapse of Albanian communism that Kadare constructed with full swing the totalitarian Other as another Oriental Other, which rather than being only the Other of the Albanian nation, is regarded as the Other of the whole humanity. It is worth noting that from the time sequence of the appearance of the Oriental Others, we can see how the Albanian national identity was constructed in accordance to the political needs of the time. It testifies to the Benedict Anderson's claim that nation is "an imagined political community" (1991: 6). Albanian national identity is also politically imagined and ever changing.

\footnotetext{
${ }^{1}$ George Orwell, Nineteen Eighty-Four. Fairfield, Iowa: 1st World Publishing, 2004.
} 


\section{CHAPTER 4 THE INTERNAL OTHER}

\subsection{Background}

When Enver Hoxha came to power in Albania after the Second World War, he had to face severe challenges of the country's viability. In most areas, especially in economic sphere, Albania was in an extremely backward situation. It basically had no industry prior to World War II. As Hasan Banja has pointed out, "The epoch of steam and electricity had nearly not affected it at all ... Industry, in the true sense of this word, was inexistent". ${ }^{1}$ Therefore, in order to speed up Albania's development and achieve the fastest possible rate of growth, Hoxha made use of foreign aid, as long as it would not impair his power of making his own decisions on domestic matters. Meanwhile, within the country, the domestic policy focused on political unification, economic industrialization, identity construction and social progress. Combats were launched to eliminate every factor that was impeding the realization of the communist regime's ambitious goal. The dominant slogan of that time was to become the "new human" with socialist consciousness. The whole population, the youth in particular, was mobilized to participate with enthusiasm in the campaign of building the new socialist Albania.

Enver Hoxha's objective for building Albania into a modern country was made clear in the announcement at the First Congress of the Party in November 1948, where

\footnotetext{
1 Hasan Banja, Establishment and Prospects of Development of Socialist Industry in the People's Republic of Albania. Tiranë: Naim Frashëri, 1969.
} 
industrialization was emphasized as the foundation for the Albanian social and cultural progress.

... fundamental economic objective was to raise the country from its profound backwardness, through a vigorous development of the forces of production... The absolute necessity for industrialization was dictated by the need to create an entirely new material technical base for the people's economy, to extend the production of goods within the country, to prepare the conditions for the reorganization of agriculture on a socialist basis, to increase the numbers of the working class so as to strengthen its leading position. ... Socialist industrialization had to be carried out at rapid rates so as to overcome the backwardness inherited from the past within the shortest possible time, to ensure the independent development of the economy and to achieve an appreciable rise in the material and cultural level of the working masses. (History of the Party of Labor of Albania, 244-245) ${ }^{1}$

In order to build the new Albania, Hoxha launched serious struggles against anything that was standing in the way toward his goal. The internal Others, as can be called in contrast to the foreign Others of the Albanian nation, became the target of eradication or vigilance. They include mass illiteracy and ignorance, religion, the blood feud tradition, female oppression, hidden desire of the eliminated old ruling class, etc. Various campaigns were launched to establish absolute political stability and promote rapid social progress. In 1955, Albania claimed that illiteracy was eliminated among all adults under forty. Not only that, young people were prepared politically and professionally to transform Albania into a progressive and prosperous socialist country. In Answers to Questions about Albania, the education policy of Hoxha's regime was explicitly explained.

The educational system in the People's Republic of Albania aims at the all-sided education of the younger generation preparing them to take an active part in the construction of the new socialist society. Its task is to impart to young men and young women

\footnotetext{
${ }^{1}$ The Institute of Marxist-Leninist Studies at the Central Committee of the Party of Labor of Albania, History of the Party of Labor of Albania, $2^{\text {nd }}$ ed. Tirana: 8 Nëntori.
} 
sound scientific knowledge, to inculcate in them the Marxist-Leninist world outlook, to give them professional skill and habits of work, to imbue them with the spirit of socialist patriotism and proletarian inter-nationalism, ensuring, thus, their all-out moral, physical and esthetical education. (353)

In 1967, the Albanian government proclaimed Albania to be the only atheist country in the world, and outlawed all religious practices. Before that, despite the nominal religious freedom prescribed by the constitution, many of the religious ecclesiastics were persecuted, the Catholic clergy in particular, because Christianity was regarded as the heritage of the Western infiltration that had damaged Albanian's independence and the religious people were considered as foreign agents. Anton Logoreci points out the reason for Hoxha's severe punishment of the Catholic clergy that "The church's links with the Vatican were also seen as dependence on an outside body regarded as intrinsically hostile to communist doctrine (154)". ${ }^{1}$ The official rationale for the campaign against the internal religious Other is as follows:

The Party of Labor of Albania has always waged a systematic struggle against religion as an ideology of the exploiting classes hostile to socialism and opium of the people. The Party has considered the struggle against religion, against religious prejudices, against backward customs directly or indirectly linked with religion, as essential for the social liberation of the working people, for their ideological revolutionary tempering and for the construction of socialist society. $(435)^{2}$

This internal religious Other was presented by Kadare through the fictional figures such as Gjon the monk in The Three-Arched Bridge and Frok the hermit in The File on H., who semi-consciously or unconsciously harmed Albania's national interest with their improper behaviors. Moreover, the religious clergy was acrimoniously denounced in Kadare's novel The Wedding, as we will see in this

\footnotetext{
1 Anton Logoreci, The Albanians: Europe's Forgotten Survivors. Boulder: Westview Press, 1977.

2 Institute of Marxist-Leninist Studies of the Central Committee of the Party of Labor of Albania, History of the Party of Labor of Albania, 2d ed. Tirana: 8 Nëntori, 1982.
} 
chapter, as an evil and immoral internal Other which cheated the ignorant people and committed crimes against Albanian women.

Guided by the Marxist theory of class struggle, the Albanian Communist Party stayed vigilant toward the overthrown old ruling class. The psychology of the old bourgeoisie class was overtly displayed in Kadare's novel concerning the break between Albania and the Soviet Union The Great Winter (1973). They secretly hoped that the Albania-Soviet split would force Albania to turn its head to the West thus taking them back to their good old days.

However, the two most important aspects of the Albanian society's fundamental transformation under Enver Hoxha which are considered to this date as positive were women's emancipation from patriarchal oppression and the elimination of the savage backward blood feud tradition.

Talking about the social oppression of women and the tradition of blood feud in Albania, we can in no way avoid looking into the Albanian customary law The Kanun $^{1}$ or otherwise Kanun of Lekë Dukagjini (Alb. Kanuni i Lekë Dukagjinit), which is the root of these two phenomena. The Kanun is closely linked to the name of Lekë Dukagjini, a contemporary of Albanian national hero Scanderbeg, who enjoyed great authority among the Albanian people because Skanderbeg said "Let it be as Leka said" (240). ${ }^{2}$ After Skanderbeg's death in 1468, Lekë Dukagjini continued the fight against the Ottoman Turks. He fled to Venice when the Northwestern Albanian

\footnotetext{
${ }^{1}$ Although Kanun is attributed to the Albanian medieval prince Lekë Dukagjini, the rules evolved over time. Many scholars suggest that it possibly dates back to the Bronze Age culture. The Kanun was written down in 19th century and published in 1913. The full version appeared in 1933 and the book was divided into the 12 sections: Church, Family, Marriage, House, Livestock and Property, Work, Transfer of Property, Spoken Word, Honor, Damages, Law Regarding Crimes, Judicial Law, Exemptions and Exceptions. It has 1,262 articles which regulate all aspects of the mountainous life: economic organization of the household, hospitality, brotherhood, clan, boundaries, work, marriage, land, and so on. Besa (honor) is of prime importance throughout the Kanun as the cornerstone of personal and social conduct. The Kanun applies to both Christian and Muslim Albanians, with its strongest influence in Northern Albanian and less important influence in South Albania. Please refer to Bernard Cook (ed.), Europe since 1945: an encyclopedia. vol. 1, New York \& London: Garland Publishing, 2001, p. 22.

${ }^{2}$ Kanuni i Lekë Dukagjinit (The Kanun of Leke Dukagjini), comp. Shtjefen Gjeçov, trans. Leonard Fox, New York: Gjonlekaj Publishing Co., 1989.
} 
city Shkodra fell in 1472, but he came back ten years later, when the fighting of Sultan Mohamed II's sons for succession to throne created conditions for his return to Albania. Though nominally under the Sultan rule, the north Albanian mountainous region was technically under the laws of Lekë Dukagjini. Inherited generation after generation by the northern Albanians from the fifteenth century, the Kanun played an important role in maintaining their individuality under the Ottoman domination. The Kanun was regarded by the Western travelers of the early $20^{\text {th }}$ century, such as Margaret Hasluck, Mary Edith Durham, etc. as a unique characteristic of Albanian nation. Their representations of Albania, almost exclusively the northern mountainous Albania, impressed the readers with mainly two images: one is that Albanians lived isolated and primitively, engaged in endless family blood feuds; the other is that Albanians were highly hospitable and unfailingly committed to their promises (besa in Albanian). ${ }^{1}$

The women's social position according to the Kanun was miserably low, which is clearly expressed in the statement that "A woman is known as a sack, made to endure as long as she lives in her husband's house" (The Kanun, chapter 5, no. 29, 38). They were viewed mainly as an addition of labor force and a tool of reproduction. They had no say in deciding whom to marry and once they got married, the Albanian women became totally subordinated to their husbands. Divorce was never an alternative, even in intolerable situation. In case of infidelity, the husband was entitled the right to kill his wife, using the bullet given by the girl's parents at the bottom of the dowry trunk. A striking illustration of the sexual discrimination against women can be seen in the stipulation concerning the fine for the murder of a pregnant woman.

\footnotetext{
${ }^{1}$ Mary Edith Durham (1863-1944) was from Britain. She wrote seven books on Balkan affairs, of which High Albania (1909) is the best known and one of the most frequently cited works to present the unique Albanian culture. Like Durham, Margaret Hasluck (1885-1948) settled in Albania and stayed there for many years. She published a lot of writings about life in Albania, with The Unwritten Law in Albania (published in 1954 by the Cambridge University Press) particularly about the Kanun.
} 
The dead woman [could] be opened up, in order to see whether the fetus is a boy or a girl. [...] If it is a boy, the murderer must pay three purses [the local currency of the time] for the woman's blood and six purses for the boy's blood; if it is a girl, aside from the three purses for the murdered woman, three purses must also be paid for the female child. (The Kanun, chapter 22, no. 130, sections $936-937,178$ )

The social status of Albanian women remained low for centuries, until the communist ideology stepped on the Albanian political stage. During the Second World War, three forces, namely the National Front (Alb. Balli Kombëtar), the Legality Party (Alb. Legaliteti) and the Communist Party, were united to some extent in the fighting against foreign invading powers. However, they were more concerned about the post-war political scenario in Albania. The former two forces were old-fashioned and took no interest in women's participation in fighting for power, whereas the Communist Party embraced the idea that women should be mobilized and equally treated in fighting against foreign invaders and interior reactionary forces. The Albanian Communist Party's attitude toward women is clearly reflected in Kadare's famous novel Chronicle in Stone (1971), in which the child-narrator's aunt and other young women left home and joined the partisans in the mountains, an incredibly horrible thing in the eyes of the local traditional women.

If during the war the Albanian Communist Party had to include women among its ranks to fight for power, then after the establishment of the People's Republic of Albania in 1946, Hoxha and his comrades were more convinced of women's indispensible role in the socialist construction. They were aware that without the active participation of women, Albania's problems such as illiteracy, superstition, poverty, lack of national consciousness, underdeveloped industrialization, etc. could not be solved. Therefore it was highly emphasized that women must be encouraged to participate in building the country. The role of women was defined in Article 41 of 
the Albanian Constitution:

The woman, liberated from political oppression and economic exploitation, as a great force of the revolution, takes an active part in the socialist construction of the country and the defense of the Homeland. (quoted from The Albanian Woman - A Great Force of the Revolution, 7$)^{1}$

In 1967, Enver Hoxha firmly expressed the Party's determination in carrying out the cause of women emancipation.

The entire Party and country should hurl into the fire and break the neck of anyone who dared trample underfoot the sacred edict of the Party on the defense of women's rights. (quoted by Anton Logoreci 158) ${ }^{2}$

Subsequently, women's political and social position in Albania was improved dramatically during the years of Enver Hoxha's reign. They became better educated and were appointed to more important positions of all sectors, in agriculture, industry, education, academia, politics, etc. The statistics on women's participation in work is an evident proof of the change.

In 1960, women accounted for 25 per cent of the working people of the various sectors of the economy, as against 4 per cent in 1938; in 1970 this percentage was 38 and in 1982 they made up 46 per cent of the total number of working people. (quoted from Ksanthipi Begeja 18) ${ }^{3}$

As an echo to the great change of women's social position, Kadare published in 1968 his novel entitled "The Wedding", which tells the story of a young woman's emancipation from the oppressive customary law of Kanun.

While women became a propelling force for Albania's political unity, social progress and economic development, the Kanun, despite its previous positive role in

\footnotetext{
1 The Albanian Woman - A Great Force of the Revolution. Tirana: 8 Nëntori, 1978.

2 Enver Hoxha, Speech given 6 February 1967, quoted in Anton Logoreci, The Albanians: Europe's Forgotten Survivors. Boulder: Westview Press, 1977.

${ }^{3}$ Ksanthipi Begeja, The Family in the People's Socialist Republic of Albania (E drejta familjare e RPS të Shqipërisë), Tirana: 8 Nëntori, 1984.
} 
preserving the Albanian national identity from the Ottoman assimilation, was regarded by the Albanian Communist Party as a reactionary and destructive force that impairs Albania's socialist construction. Besides, the fact that most of the Albanian communist leaders were Tosk, i.e. southern Albanians also contributed to the othering of the Kanun. When the new Albania was founded in 1946, the Albanian Communist Party had a complete control of the southern area but not the vast northern mountainous area called Malësi. Like the religious force in northern Albania, the Kanun force represented by clans held a resistant or hostile stance against the Albanian Communist Party. In order to gain absolute power over the northern area, Hoxha's regime had to eliminate the authority and influence of the northern clans and religious clergy. In other words, the Kanun and religious forces must be portrayed as the Other of the nation and smashed down.

The barbaric and inhuman blood feud tradition that is rooted in the Kanun legitimated the communist regime's crackdown of the forces representing the Kanun culture. In northern Albania as well as in Kosovo, it was quite common that violation of personal, family or tribal honor eventually resulted in murder. And according to the Kanun, blood must be paid by blood. In other words, the retaliatory killing was expected to protect the honor of oneself or his family. It applies to any male member of the extended family of the killer. In this way, the mutual hostility and killing may last between two families for generations. Consequently the population reduced and those who were afraid of being murdered shut themselves at home, overloading the women with all the extra outdoor work. Therefore, from the economic perspective, the eradication of blood feud means the liberation of labor force fettered by the backward tradition.

In 1955, the Albanian government claimed that the phenomenon of blood feud 
had been eradicated within Albania proper. This campaign led by the Albanian Communist Party is viewed also today by most critics as a positive contribution of Enver Hoxha's regime to Albania's history, because, as noted by Ramadan Marmullaku, the blood feud was affecting negatively the economic development and social progress.

The gravity of this phenomenon, however, should not be measured simply by the numbers of lives lost, but rather by its economic, political, social and psychological consequences, the most grievous of which is certainly the cases of closed families those which owe blood and live more of less under house arrest, self-imposed of course, often for as long as ten years or more. Such isolation has enormous implications for society - economic (unfilled fields), social (restricted movement), political (a suspicion of society and 'the authorities' in general) and psychological (constant fear for one's own life). (88) ${ }^{1}$

The eradication of the blood feud marks the elimination of the Kanun as an influential customary law in the new communist Albania. The Kanun, being the origin of women's oppression and blood feud, as well as a threat to the Albanian communist totalitarian rule, was defined as the Other that should be eliminated. Apart from the social progress, the combat against Kanun contributed also to the Albanian national unity, bringing the people to the sole allegiance to the Communist Party. Gradually, guided by the official nationalism, the northern Albanians gained a strong national consciousness.

To sum up, after Hoxha assumed power in Albania, he set up an ambitious goal to build Albania into a modern industrialized country. While being cautious in making alliance with countries that supported Albania's development, he dealt with an iron hand the domestic problems. Those who were ideologically different from the communist regime were all persecuted. The religious clergy, the Kanun

\footnotetext{
1 Ramadan Marmullaku, Albania and the Albanians, trans. Margot and Bosko Milosavljevic, Hamden, Conn. Archon Books, 1975.
} 
representatives, members of the old bourgeoisie class, were all regarded as internal Others or enemies of the people. Campaigns were launched for the elimination of these internal Others. The media under the communist control played an important role in this course. Kadare as the most influential writer also wrote on these themes. This chapter examines the two novels Kadare dedicated to the themes of women's emancipation and the blood feud: The Wedding which applauded the Albanian communist victory in the campaign against the oppressive Other, and The Broken April which presented the Kanun as an evil exploiting Other, a blood-sucking vampire of the people. Though no specific work was written ad hoc by Kadare to portray the religious clergy as the Albania nation's Other, quite a few religious figures were created to showcase their negative role and their evil-doing in the Albanian history. In fact, the oppressive Other constructed in The Wedding comprises of the Kanun Other and the religious Other. Other internal Others can be detected in Kadare's works, for example, the depiction of the psychological change of the old bourgeoisie members who longed for Albania's Westernization was indeed an important part of the novels reflecting the Albania-Soviet split and the Albania-China split. But they are not the major targets of Albanian communist regime's othering of the internal reactionary forces.

\subsection{The Oppressive Other}

The core of Marxism is the emancipation of the working class. According to Marxist theory, one important method taken by the ruling class to dominate the society is the break-up of the unity of workers into different social groups, including man versus women. Like other oppressions, the women's oppression by man is also rooted in their economic dependency. Oppressed economically by a variety of means 
including glass ceilings, controlling spouses and societal attitudes, the women become the subservient beings they are expected to be. The cycle feeding the oppression of women in turn feeds the cycle of economic oppression on them. Therefore the communist revolution must smash women's economic dependency in order to liberate them from oppression. This is made clear by Lenin in 1919 in his speech at the Fourth Moscow City Conference of Non-Party Working Women.

The status of women up to now has been compared to that of a slave; women have been tied to the home, and only socialism can save them from this. [...] Owing to her work in the house, the woman is still in a difficult position. To effect her complete emancipation and make her the equal of the man it is necessary for the national economy to be socialized and for women to participate in common productive labor. Then women will occupy the same position as men. (Lenin 40-46) ${ }^{1}$

In Albania, guided by Marxism-Leninism, Hoxha's regime took the same reform. Women were encouraged to leave home and participate in public labor, such as building railways, reservoirs, hydropower stations, etc. The Wedding reflects the vigorous development of the campaign for women's emancipation under the leadership of the Albanian Communist Party.

The heroine of the novel Katrina is a young girl from the northern mountainous area who escaped from traditional peasant life to participate in the infrastructure construction work initiated by the government. A newly-built railway station is presented to the reader at the very beginning of the novel. Being so remote from any populated place, the station has not received a name yet. Nevertheless it was a quite lively with many young voluntary workers. One Saturday, the station was full of celebratory atmosphere. The worker's barracks were full of people. Katrina was going to marry Xheviti, the technician she got to know on the construction site. Xheviti was from Tirana. Like all the other technicians, he moved from one place to another to

\footnotetext{
${ }^{1}$ Vladimir. I. Lenin. Lenin's Collected Works, 4th English Edition, Progress Publishers, Moscow, 1965, Volume 30 . 
work in new factories and therefore had many friends all over the country. People were coming from different parts of the country to attend the wedding, the first wedding in the town which was going to be built near the new railway station. The wedding is not only an important event for the new weds, but more importantly, as the manager's remarks show, it has a symbolic meaning.

This wedding is taking place at a time when our workers' collective, like all the workers of the country, have mustered all their efforts to accomplish the tasks of the first three-month period of the plan. . . (16)

Apart from the friends of the new couple, people from other walks of life came to the wedding, e.g. the journalist, the writer, the Chinese experts, the ethnologist, etc. Yet, some unexpected guest's arrival made the wedding quite gloomy. It was Katrina's father. People were worried that something unpleasant might happen. Some were even afraid that the old man might have a pistol with him and would kill his daughter, because they knew that Katrina had been engaged to someone in her home village and according to the Kanun, breaking the engagement is a dishonor to the family which should be punished. Fortunately, nothing terrible happened. During his three-hour stay, the old man sat by her daughter's side without uttering a single word. He recalled in memory things that had happened in the past. The day when he got married, the wedding guests who escorted the bride to the groom's house took another road for it was rumored that a sorcerer had cast a spell on their way. He was so happy when he saw the white steed with the bride on it appear safely. The wedding party proceeded smoothly. But the evil spirit finally fell on him, the day after the wedding party was over. His elder brother who had an argument with a guest during the wedding was shot dead. His third brother revenged for their elder brother's death and was then killed in revenge. It was his turn to take revenge for his third brother's blood but he delayed it. He wanted to wait until he had reaped the wheat he planted for his family, 
now a family with newly born baby. His enemies started to provoke him by coming out in the open, to the downtown, to the crowded coffeehouse or even face to face with him. He went to the priest for advice. However, instead of any advice, he received humiliation: the priest handed him coffee below his knee, a sign of disdain for those who had delayed the revenge. Eventually, he killed the enemy without having reaped the wheat. Thereafter he had to hide in the house and the family suffered famine. The old man could not help thinking of the painful old days. He felt painful that his whole clan had been wiped out by blood feuds, now he felt lonely that his daughter had deserted him.

In the novel we can see the conflict between the new ideology and the old tradition, the former represented by the new couple and their friends led by the Communist Party, the latter represented by a few Northern mountaineers who came to destroy the wedding. The go-between and someone from the family of Katrina's fiancé are the representatives of those who benefitted from the old Kanun system. The go-between is the most dangerous person. He not only evilly cursed the wedding, but also damaged one of the rails before he left. The damage was discovered and quickly repaired by the mechanics. The locomotive symbolizes the Party, which led the Albanian people in their new socialist construction toward communism. Though the train had to stop due to the damage, it waited only six minutes, implying that sometimes the socialism might be hindered by the enemy, but supported by the people it will march toward victory.

Katrina's psychology is described in detail. To her the Party is a true savior which brought her a totally new life. From her recall we learn how she was engaged without her own consent to a middle-aged man of a distant village and how she was deprived the right to go to school. For eight years, she lived in the shadow of the underage 
engagement. She escaped from the grip of the patriarchal control when she and other girls from the mountains were called on by the Communist Party to participate in public labor for socialist construction. The experience of voluntary work opened her eyes. She realized how isolated she had been and was elated by the new horizon of socialist life. Finally Katrina broke the fetters of the Kanun and asserted her rights as a human being. Her wedding marks the victory of the women emancipation campaign over the backward tradition.

The author made it clear at the very beginning of the novel that Kanun is the root of women's oppression. Those who heard that Katrina's father came argued about their concern based on the Kanun.

It is written in the Canon ${ }^{1}$. The father carries a bullet with him. [...] The Canon has it: "the girl is sent to the groom's house with a bullet in her bridal chest. (22)

The Kanun is described as "a spell which raised its head like a viper ready to strike" (37). Half a century ago, it struck Katrina's parents on their wedding day. While the male members of the family were forced to take revenge, the females suffered no less.

Blood feud had confined part of the men of the village to their houses. They dared not emerge because revenge-seekers were on the lookout. Through the narrow lattice windows they watched the fields where their womenfolk worked all day. (39)

As an instrument of the oppressive system, the writer attending Katrina's wedding points out, the Kanun planted fear and imposed misfortune on numerous people.

The features of an Albanian wedding are tense and fraught with fears because there is always some threat, some opposition, something negative hovering over it. [...] Betrothals from motives of interest, the pledged word and going back on it, insults, old feuds, threats to the clan, all these things went to creating those

\footnotetext{
${ }^{1}$ The Kanun has been translated into English as Canon or Code. However nowadays, many people choose to use the original Albanian word Kanun, so that it can be distinct from the Canon law of Catholic Church or other legal codes. This dissertation also uses directly Kanun, but when it comes to citation, the word "Canon" or "Code" will be maintained as it is in the text.
} 
black contours which hovered like winter clouds over our weddings. [...] Gaiety and alarms were bound together like Siamese twins. (93)

Commenting on the content of the Kanun in terms of its gender discrimination and the miserable status of the Albanian women, the writer ${ }^{1}$ said:

The Canon has many dark sides to it, but anyway, the part which speaks of women is the most cynical of all. [...] The deadliest poison is hurled at the women. (81)

This novel, as Kadare himself also admits, is written particularly to applaud the achievements in socialist Albania under the Hoxha's leadership. Therefore the oppressive Other, i.e. the Kanun and the relevant old traditions, were being smashed to pieces and giving way to social progress.

"Albania is being shaken up" said the writer, "The mountains want to shake off the Canon, old prejudices and superstitions from their backs. This requires a gigantic effort. The Canon is tough and nearly as old as the mountains. At times one can't tell where the mountain ends and the Canon begins. They are entangled and have penetrated into each other. [...] Do you know what it means to break off thousands of under-age betrothals within two months? This is the Waterloo for the old world." (57)

Everybody was happy except those affected by the revolution. The manager congratulated the new couple for "joining in wedlock at the time when our people as a whole are exerting their efforts to build socialism, raising the women to posts of responsibility" (40) That is to say the Albanian socialism was in its full swing in the 1960s while fully liberating the female labor force from the Kanun oppression.

Katrina's sufferings and the fear she used to have for horrible future life provide the most powerful evidence of how women had been oppressed under the Kanun rule in Albania. The concrete person who caused her sufferings is the go-between.

That was when this horrible man with a lump on his neck entered my life. He follows me everywhere. He wants to deprive me of

\footnotetext{
${ }^{1}$ The writer's name in The Wedding is S. K.. Like in many other novels, such as The Great Winter and The Concert, the reader can always identify to great extent the figure of the writer with Kadare himself.
} 
the beautiful highways, cities, the sea, the trains, and my companion. In compensation for all these he wants to give me a half-lit nook and the solitude of subjugation to a forty-year-old man I have never seen. He wants to deprive me of my bobbed hair, clean underwear, wall bulletins, books and songs, and in their place to give me a black kettle, a lash rope to haul firewood, filth, and beatings. (178)

For years in succession he haunted me. He penetrated unexpectedly into my innermost thoughts, into my dreams disturbing my sleep and freezing my heart. He haunted me everywhere, in the dark corner of my room, in my father's wrinkles, at the crossroads where the main highway started that led to distant, unknown places. (173)

The reason why Katrina was so fearful was that behind the go-between stood the powerful Kanun and the rifles that guard their interest. She, like all the other girls, was merely a commodity.

Horrible intermediaries, roaming night and day from one village to another, from one district to another like spiders, had fastened us with undetachable ropes. Hundreds of rifles stood guard over these bonds. Some of us had been bought for cash, some had been exchanged for cows, sheep, horses, sacks of corn and even for shepherd's dogs. (72)

Even when she was far away from her village and amongst her comrades, she could feel the approaching of the go-between, coming in the way like a snake. She could not feel the delight of getting married to her beloved person. She knew that on the wedding night the desperate enemy would kick the final strike. But Katrina was not more afraid of it.

The sound of a snake's scales has been following me for years. Every time I was in high spirits I suddenly heard it and my joy vanished. [...] Tonight it is more threatening than ever. The snake intends to strike but it is too late. I am no longer afraid of its bite. (174-175)

Katrina and the other girls took the courage to confront the Kanun because they were backed by the Party. After Hoxha made his speech in 1967 where he promised to punish severely all those standing in the way of women's emancipation, the girls 
decided to declare war against the Kanun.

Our dormitory was larger than a tent of the General Staff. And decisions were harder for us than for the generals. Our battlefield had no bounds. One of them shouted: "Girls, don't worry, we have our Party. It will not leave us in the lurch." (73)

Toward the end of the novel, Katrina declared victory on the accursed go-between, i.e. the one who made profit out of the oppression of women based on the Kanun.

He will soon become a distant evil just like all other evils of the past. I used to be frightened by his shadow, by the lump on his neck, by his carbine. But now that I have come to see things, now that I have come to know socialism, now that I have realized that I am not alone, he looks ridiculous to me. [...] You have brought to grief so many sisters and brothers of mine. You penetrated like a pest into their lives leaving great sorrow and misfortune behind. You must be trampled underfoot like a worm wherever you may appear. Linger on in the mudholes of this plain, o despicable go-between! (178-9)

The course of women getting rid of social oppression is accompanied by the spiritual enlightenment and social integration of the women, especially those from the backward and isolated areas. It strengthened their national consciousness and their identification with the fatherland. Among their new friends and treated equally, they gained a strong sense of social belonging.

As we zigzagged our way down, different vistas opened up before our eyes. This then was our fatherland. We had often read the word "fatherland" in our readers. It was often written in chalk on blackboards and the teacher had explained to us that this word comes from the union of the words "father" and "land". We had read that our fatherland is beautiful, but we had seen nothing of it. A very small part of the fatherland had been our portion. What belonged to us was a limited plateau and a rugged ravine beyond which we could never go. (66-67)

How could I imagine that a day would be coming when I, Katrina, shy from the mountains would unexpectedly gain so many comrades and friends? I knew that a woman could have a husband but never comrades and friends. (67)

Apart from Katrina, the novel also tells about the story of two other women who were cheated into a Bektashi monastery. They were taken to the monastery which was 
said that "if one slept a night one's wishes would be fulfilled" (153).

"I will never forget that horrible night" Her sad eyes [referring to one of the two girls] squinted at the wet darkness beyond the doorway. She heaved a sigh and tried to recall that sultry afternoon three years before when, as fifteen-year-old orphans they had ridden in a peasant's cart taking this road through the barren plain for the first time. [...] When they left the monastery they realized that their young lives would take another course from now on, just as a river changes its course after a wild and stormy night. (153-154)

The next day when they realized what had happened, they had lost their virginity. Their misfortune caused by the despicable monks, and the story of a peasant's daughter-in-law getting pregnant after spending one night in the monastery, are designed in particular by the author to construct the religious Other. Let's take a look at the conversation between a young man and an old peasant on the train.

"Religion has wrought havoc, don't you think, uncle?"

"What can say, son. The Party always tells the truth and we believe the Party. But there have been cases in which the monasteries have done some good."

"Which monastery, for instance?"

"Somewhere here about" he repeated, "We may have passed it. A very old monastery. Until a year ago people from all parts of the country used to come here to find relief."

"To find deceit, poor folk."

"By God, no!" said the peasant, "Sometimes they performed miracles. Take the case of my daughter-in-law. She gave birth to no children after four years in succession. Believe me. She went one night and slept in the monastery. Nine months later she gave birth to a healthy baby son." (83)

By unmasking the crimes committed by the religious clergy on women, the novel aims to wake up the blind belief of the ignorant people in religion and the "miracles" performed by the monastery.

Katrina's father represents the mountaineers imbued with backward ideas. He did not utter a word but the reader can feel the struggle and pain in his inner world. $\mathrm{He}$ suffered from the Kanun system, but over time he became part of the Kanun mechanism. He was perceived by Katrina as tough and chilly, a victim and at the same 
time a slave of the Kanun.

Father's wrinkles seem to be part of my childhood as the pathways of my home village are. [...] My father's face is like the face of the earth eroded by floods and droughts. Now it looks frozen, stiff. And his hair looks like frost. (76)

Every time the door opens and somebody enters, I feel the cold and wet of the night. Father seems to have gathered this cold wetness in the shawl about his head, poor father! He has suffered a lot from customs; still he lacked the strength to discard customs. (68)

He used to tell me how he had burnt with the desire to come to grips with the spell [hovering over his wedding], but it was invisible and untouchable. And here tonight after many years, it is father himself who is hovering over my wedding like a gloomy, inconceivable ghost, like a spell from long ago. (140-141)

However, concerning Katrina's father, one thing should be noted. Though he is depicted as negative element hindering the social progress in new socialist Albania, he is not regarded as in the same group with those representing the Kanun interest.

This, of course, is not an antagonistic contradiction, yet we should be careful for, as you know, non-antagonistic contradictions may easily turn to antagonistic ones. In short, we should have done more to clarify the old man. (106)

Here we can see the Chinese influence and application of Mao Zedong's theory of antagonistic and non-antagonistic contradictions. In other words, according to the novel, the old man should not be viewed as the Oppressive Other. He is a character that makes your heart ache.

The Kanun is called "a monster in book form" (148). However, in terms of the role of Lekë Dukagjini, the author expressed very cautious thoughts. After all, he was Scanderbeg's good friend.

He was a great soldier. He had often seen people murdered in front of his own eyes. He could not have hated and thought so little of women. He knew what a soldier's mother a soldier's wife meant. I don't believe he wrote it. (149) 
In this way, Kadare put himself in a safe place. Then he turned the pen against religion, the divisive force of Albanian nation ever since the ancient times. Asked whether the clergy might have had a hand in it, the writer said:

Certainly, they had a hand in it. In medieval times religion dictated laws both in the East and in the West. But in this case all the other social and political forces of obscurantism have taken part in it. (149)

He compares the wedding party as an open bonfire, where "bigotry, ignorance and religion hover round about but do not dare to come too near just as beasts do not dare to come near a shepherd's bonfire" (149). Nevertheless he never forgot to point out the true nature of the oppressive Other: "The Canon was dictated by the economic and social structure of the times" (81).

As can be seen from above, The Wedding treats the issue of Albanian women's oppression by the institutions such as the Kanun and religion. But if we take into consideration the sufferings of Katrina's father, as well as the social backwardness caused by the women's oppression, we come to understand that it really deals with the oppression of the whole Albanian nation by these oppressive institutions. It is not only about women's liberation from patriarchal oppression. Tremendous conflicts surrounding women's emancipation made their appearance in the novel. Through Katrina's "song of liberation" against the Oppressive Other, Kadare conclusively links the emancipation of women to the industrial transformation of Albania and the construction of a modern, unified national identity in the country.

\subsection{The Exploitative Other}

The word "exploitation" is most often used to refer to economic exploitation. According to Marx, "all history has been a history of class struggles, of struggles 
between exploited and exploiting, between dominated and dominating classes at various stages of social evolution; that this struggle, however, has now reached a stage where the exploited and oppressed class (the proletariat) can no longer emancipate itself from the class which exploits and oppresses it (the bourgeoisie), without at the same time forever freeing the whole of society from exploitation, oppression, class struggles (6)". ${ }^{1}$ That is to say, the Marxist solution to this social injustice of exploitation is the abolition of capitalism and its replacement of a non-exploitative system, first by socialism, and ultimately by communism.

Like in all the other former socialist countries, Albania endeavored to fully abolish the exploitative system. However, while it was much easier to clamp down the people who comprised the former ruling class, it was not that easy to eliminate the ingrained influence of the former superstructure in the form of culture, ritual, etc. That is why Marx pointed out in his address in 1871 to the International Workingmen's Association that after the Paris Commune seizing the government, "the working class cannot simply lay hold of the ready-made state machinery, and wield it for its own purposes" (58). ${ }^{2}$ In other words, if a revolution destroyed economic exploitation but failed to destroy the forms of oppression that buttress the exploitation, it would be hard to maintain its success.

The Broken April is written particularly to portray the Kanun as the Other of Albanian nation, which had been used by the ruling class as an instrument of exploitation. If in The Wedding the author only touched upon the exploitative nature of the Kanun, here he makes it his main theme. He goes into details to unmask the intrinsic nature of the Kanun, so that to convince the people that their centuries-long

\footnotetext{
${ }^{1}$ Karl Marx and Frederick Engels, Manifesto of the Communist Party, February 1848. Source: Marx/Engels Selected Works, Vol. 1, Progress Publishers, Moscow, 1969, pp. 98-137. Trans.: Samuel Moore \& Frederick Engels, 1888. Retrieved from http://www.marxists.org/archive/marx/works/download/pdf/Manifesto.pdf accessed Jan. 30, 2013.

${ }^{2}$ Ibid.
} 
blood feud tradition should be discarded.

The novel is set in the early 20th century, during the first and only modern Albanian monarch King Zog's reign. Two narrative lines run almost parallel to each other in the novel: one is about the subjugation of a young mountaineer to the blood feud tradition and his father's will, which led to his own death; the other is about the honeymoon experience of a young couple from Tirana in the mountainous area where everything was regulated by the Kanun.

It opens with the protagonist Gjorg Berisha lying in ambush to avenge his brother. His shot his enemy Zef Kryeqyqe, and before he left he turned Zef's body on his back and put his gun beside his head, as demanded by the Kanun. As a matter of fact, he did the killing completely out of the obligation to uphold his family's honor, the common moral practice in the zone under the rule of the Kanun. For a whole year and a half, he had been wrestling with the age-old tradition and his father's complaints. The blood on his brother's shirt was turning increasingly yellow, which, according to the Kanun, was calling for revenge. On March $17^{\text {th }}$, Gjorg finally carried out his obligation, thus turning himself into the next object of revenge.

Gjorg's family got involved into blood feud because an unknown guest who spent a night in his grandfather's house was killed the next day when he was leaving the village. Though the murder was committed when his grandfather's brother who was accompanying the guest had already turned his back for heading home, the judgment based on the direction of the killed guest's head had it that Gjorg's family was responsible for revenging the guest. That happened seventy years ago and since then it had claimed twenty two lives on each side of the families in blood feud.

Immediately after Gjorg's revenge, a delegation of four elderly people went to the Kryeqyqes family to ask for a 24-hour grace period (Alb. besa). During the 24 hours, 
Gjorg had to attend Zef's funeral to honor the man's soul. Everything went well and then a thirty-day grace period was granted, which means that Gjorg's life would not be threatened till April $17^{\text {th }}$. To Gjorg April was broken into two halves, the safe and the unsafe.

According to the Kanun, Gjorg had to go as soon as possible to the Tower of Orosh to pay the blood tax. Orosh is said to be the administrative center of the High Plateau, where all kinds of taxes are paid, including the blood tax. Readers get to know from the novel that it is a few days far away from Gjorg's village. But it is unclear why a blood tax should be paid for revenge killing, because the general understanding is that the blood feud is the same as the tax. One possible guess is that the blood taxes were collected for the protections, the arbitration, the law reinforcement, etc. Orosh provided to maintain social order.

On his way back home, Gjorg saw a young couple from the city coming out of the inn where he had dinner three days ago when he was heading for Orosh. Though it was only a quick glimpse, the young lady's beauty stunned Gjorg and left a deep impression on him. Feeling bored of staying home, Gjorg decided to wander about the High Plateau for the remaining safe days. When he heard others talking about the young lady from Tirana travelling in a carriage across the High Plateau, he realized that it was his subconscious desire to see that woman again that drove him to set out on the road.

The couple from Tirana was invited by the prince to visit Orosh. Bessian Vorpsi, the husband is an upper middle class writer who just got married. Unlike his friends who usually spent their honeymoon in the Albanian Riviera or Italy or even France, Bessian announced that he would like to spend the honeymoon in the desolation of the northern Albanian Alps. Though his bride Diana was rather startled at the beginning, 
she quickly agreed. Some of her friends envied her for they were spending a special honeymoon in the world of legend, literally the world of epic that scarcely exists anymore. Bessian and Diana were fascinated by the romantic prospects of their journey to the mountain tribes, where life was primitive and untouched by modern civilization.

However, the deeper Diana travelled into the mountains, the more disturbed she became, particularly after she saw the pale face of Gjorg whose death had been marked for with his black ribbon on his right sleeve, like a tree marked "to be felled in the forest" (117). Diana couldn’t forget Gjorg's face. Bessian was worried about Diana's increasing coldness toward him. In order to cheer her up, they decided to take some natural sightseeing. On their trip to a nearby lake, they saw people gathered at the village square, where Ali Binak, the most authoritative interpreter of the Kanun, was judging a difficult case regarding the right of blood revenge. While debating about the nature of the Kanun with Al Binak's doctor assistant, Bessian found his wife missing. He was stupefied to learn that Diana had entered a refuge tower for men threatened by blood revenge to take shelter. There were altogether 74 such refuge towers in the whole region and never had a woman stepped in any of them. When the priest and Ali Binak were moving toward the tower to rescue Diana, she suddenly appeared at the gate. It was a relief that there was no slight trace of her having been harassed. Nevertheless, Bessian was mad because he knew that Diana was looking for Gjorg. Eventually, Bessian's morbid fascination with the bloody custom and Diana's erotic attraction to Gjorg, a growing obsession which draws her indeed into the other world, led the couple to estrangement.

On the other hand, Gjorg was also wandering across the High Plateau looking for Diana. He had such a strong feeling for Diana that he imagined himself killing those 
men with bad teeth talking about Diana in dirty inns. April seventeenth came but Gjorg did not have a chance to see the carriage again. The grace period granted to him would end at noontime. Disappointed, he decided to go home and hide. It was at that last moment he met another man with black ribbon who told him that the carriage of the Tirana couple would be passing on a nearby road, the Road of the Banners. Without any hesitation, Gjorg left the road under besa protection and rushed toward that the Road of Banners. But instead of meeting with Diana, he met death: someone from the Kryeqyqe family killed him for revenge.

The story is in the true sense heart-wrenching. The life of the young man was counted by days and hours. If Diana was more charmed by the tragic beauty on Gjorg's pale handsome face, then the readers would be more inclined to feel sympathetic for Gjorg, because from the very beginning of the novel and repeatedly, the author presents Gjorg as a victim to the Kanun.

They remembered persons punished by their own families, whole families punished by the village, or even whole villages punished by a group of villages, or by the Banner. But luckily, they said with a sigh of relief, no such disgrace had fallen on their village for a long time. Everything had been done according to the old rules, and not for ages had anyone had the insane notion to break them. (18)

For a year and a half it had hung blood-soaked from the upper storey of the house, as the Kanun required, until the blood had been avenged. When bloodstains began to yellow, people said, it was a sure sign that the dead man was in torment, yearning for revenge. The shirt, an infallible barometer, indicated the time for vengeance. By means of the shirt the dead man sent his signals from the depths of the earth where he lay. How many times, when he was alone, had Gjorg climbed to that fateful upper storey to look at the shirt! (22)

Many of the prescriptions of the Kanun are introduced to the readers through Gjorg on his way to Orosh when he recalled relevant regulations of the Kanun and stories related to blood feud as he saw cairns, burnt-down houses or even a whole 
village for violating besa, the mills, the churches, etc. He finally came to realize the inter-relationship between the blood-feud chapter and the non-blood-feud chapters of the Kanun.

The rules of the blood feud were only a small part of the Code, just a chapter. As weeks and months went by, Gjorg came to understand that the other part, which was concerned with everyday living and was not drenched with blood, was inextricably bound to the blood part, so much that no one could really tell where one part left off and the other began. The whole was so conceived that one begat the other, the stainless giving birth to the bloody, and the second to the first, and so on forever, from generation to generation. (27)

Other bizarre stories concerning blood feud were told through Bessian's mouth as he was explaining the features of the Kanun to Diana or through his eyes as he saw twice how Ali Binak came to solve complicated cases. All these depictions serve to construct a formidable Kanun, the real nature of which was unmasked through another important figure in the novel: the blood steward of the Orosh fortress, the Prince's first cousin Mark Ukacjerra. It is through this fictional figure that Kadare attempted to expose most powerfully the exploitative nature of the Kanun.

Mark Ukacierra appeared in chapter four, the latter half of the novel when Bessian and Diana arrived at Orosh. He knew that the young couple was invited by the prince "to see what he [Bessian] had in mind and to persuade him to adopt his own views (133)". Nevertheless, he disliked them, particularly the woman's attitude toward the Kanun.

By her expression he had understood at once that she had doubts about certain things that were being said around the table. Some of the opinions offered - quite discreetly - by his master, the prince, which had always seemed to him to have the force of law, to be beyond discussion, quietly fell apart, annihilated, as soon as they came before that young woman's eyes. [...] The words dissolved in her eyes, lost their strength. And after the words, a 
wing of kulla ${ }^{l}$ collapsed, and then himself. (133)

Mark Ukacierra did not like the young couple because they came from the city, from where an ill wind was blowing to the High Plateau, attacking the very pillar of the Kanun, the Orosh. He was resentful because the prince seemed to hold him personally responsible for the reduced revenues generated by the blood tax. As Ukacierra examined figures in the ledger book dating from the $17^{\text {th }}$ century, he was alarmed that the ill wind had become so strong that if Gjorg Berisha had not killed on 17 March, that date would have marked the first day without killing.

Thinking of that day, he felt that if that day had really passed as it very nearly had, all of that mill of death, its wheels, its heavy millstones, its many springs and gears, would make an ominous grating sound, would shake from top to bottom, and break and smash into a thousand pieces (153-154).

The ill wind from the city Ukacierra referred to was the modernization of the city and the negative attitude of the city people toward the Kanun tradition, especially those regarding blood feud. It was this modern wind that caused the reduction of killings on the High Plateau.

The number of killings had fallen year after year, and the first season of the current year had been disastrous. He had sensed that, and had awaited anxiously the accounting that his assistants had drawn up for him a few days before. The results had been even worse than he had feared: the monies collected were less than seventy percent of the revenue of the corresponding period in the preceding year. And this at a time when not only the bailiff in charge of croplands but all the other managers in the Prince's service, the bailiff for cattle and pastures, the bailiff for loans, and most of all, the bailiff for mills and mines, who attended to all the trades that required tools, from looms to forges, had paid large sums into the general treasury. As for himself, the chief bailiff (for the sums realized by the others came sole from the holdings of the castle, while his were levied upon the whole of the High Plateau) who at one time used to collect sums equal to the total of all other revenues, he now brought in only half the amount of those monies. (136)

\footnotetext{
${ }^{1}$ The Albanian word Kulla derives from the Turkish word kule which means tower, citadel or fortress. The traditional kulla in northern Albania is a fortified tower, usually two or three stories high with thick stone walls and small windows.
} 
As can be seen, even at the time of its declining, the blood tax still accounted for half of all the other sorts of revenue. That the money of blood tax collected by the Orosh used to be the most important income was evident in the The Blood Book kept in the library of Orosh.

He took out a thick, leather-bound ledger. This was The Blood Book. From some time he leafed through the stout pages filled with dense script in double column. His eyes took in nothing, merely skimming coldly over those thousands of names, whose syllables were as alike as the pebbles of an endless beach. Here were detailed descriptions of the feuds of the entire High Plateau, the debts of death that families of clans owed to one another, the payment of those deaths by the parties concerned, the cases of vengeance not yet satisfied that would keep the feuds alive ten, twenty, sometimes one hundred and twenty years later, the unending accounts of debts and payments, of whole generations annihilated, the blood-oak (the male line, or the line of inheritance), the milk-oak (the line of the womb), blood washed away by blood, so-and-so for so-and-so, one for one, one head for another, four brace killed, fourteen, eighty, and always blood that was still to be shed; blood left over that, like the ram that leads the flock, draws after it new multitudes of the dead. (137)

This exploitative nature of the Kanun was denounced by someone in an article entitled "Blood-feudology", where he used many foreign expressions that Ukacierra could not understand, such as "blood industry", "blood merchandise", and "blood-feud mechanism". Ukacierra thought of the article with full hatred.

One such article - absolutely criminal - that made the prince sleepless for many nights, and had even been accompanied by calculations that amounted to bookkeeping, had been published anonymously four months ago by one of those accursed journals. In the table presented were the figures, astonishingly accurate, of all the revenues under the heading of blood tax collected by the castle of Orosh in the course of the last four years; they were compared with other sources of income: those from corn, from cattle, from the sale of land, from loans at high interest - and senseless conclusions had been drawn from those figures. One of these was that, supposedly, the general decline that was the hallmark of our own era was reflected in the decay of such keystones of the Kanun as the bessa, the blood feud, the status of one's guest, which having been at one time elements of sublimity and grandeur in Albanian life and become denatured in the course of time, changing gradually into an inhuman machine, to the point 
of being reduced at last, according to the author of the article, to a capitalist enterprise carried on for the sake of profit. (141)

The nature of Kanun as a profit-making institution is also shown in Ukacierra's sole interest in things that would bring him blood revenue. The more quarrels and disputes, the happier Ukacierra was.

The High Plateau had an abundance of streams, of deep gullies, snow, prairies, villages, churches, but none of that was of interest to him. For Mark Ukacierra, all of the great plateau was divided in two parts only - the part that engendered death, and the part that did not. The portion that bore death, with its fields, its objects, and its people, passed slowly before him in his mind, as it had often done: There were tens of thousands of irrigation canals, large and small, running from west to east, or from south to north, and on their banks there had sprung up countless quarrels that gave rise to feuds; hundreds of mill-races, thousands of landmarks, and these gave birth easily to disputes, and then blood-vengeance; tens of thousands of marriages, some of which were dissolved for one reason or another, but which brought one thing only - mourning; the men of the High Plateau themselves, formidable, hot-tempered, who played with death as if they were playing a game on Sunday; and so on. (143)

Families involved in blood feud suffered not only psychologically, but also economically. Apart from the pain of losing their dearest family members, they had to face poverty and famine. The five hundred groschen of blood tax was indeed a huge sum of money for a peasant family.

The purse was now in Gjorg's right hand. It seemed heavy. In it was all the money the family had saved, scrimping from week to week and month to month in anticipation of just this day. (21)

And for families which had to leave the field fallow meant no sufficient food. Moreover, the villages became desolate. "Of the two hundred households of our village, only twenty are not involved in the blood-feud. [...] The village looks as if everything had turned to stone, as if the plague had struck it" (173).

However, none of these predicaments was within Ukacierra's attention. As the chief revenue officer, the only thing he cared about was how to keep steady the 
income from blood tax. Therefore he "was always attentive to the connection between cultivated fields and the fields that lay fallow. [...] Those fields [that lay fallow] were the special joy of Mark Ukacierra (147)". He, like all his predecessors, would be happy to refer to the ledger book and tell those who had been in peace for a long time that they had forgotten their debt of blood.

The book was old, perhaps as old as the castle. It was complete, and it was opened when people came to consult it, people sent by their family or their clan who had been living in peace for a long time, but who suddenly - because of a doubt, a supposition, a rumor, or a bad dream - felt their tranquility shaken. Then the steward of the blood, Mark Ukacierra, like some dozens of his predecessors, would open the thick pages of the book, searching page by page and column by column the spread of the blood-oak, and stop at last at one place. "Yes, you have debt of blood unpaid." In case of that kind, the expression of the steward of the blood was one of stern reproach for the long period of forgetfulness. His eyes seemed to say, your peace has been a falsehood, unhappy man! (137)

When he was desperate about the shrinking income from blood tax, he would even think of involving directly the women into the mechanism of blood feud.

At times, Mark had thought of mad things that he dared not confess to anyone. Oh, if only the women as well as the men were subject to the rules of blood-letting. [...] that seldom happened, only sometimes at the end of the month or the quarter, when he felt despondent because of the figures in the ledger. (144)

Apart from the blood steward of Orosh, Kadare created another figure to unmask the nature of blood feud: the anonymous doctor who appeared twice as the assistant of the Kanun interpreter Ali Binak. The doctor was one of the first group students sent by the Albanian government to Austria where he studied medicine. He worked for Binak because he could not find a suitable job after he got back to Tirana from study abroad. His job was only to count the wounds and clarify them, because, according to the Kanun, the wounds inflicted are paid for by fines. When Bessian accidently met the Binak group for the second time, they were arbitrating between two families both 
of which claimed the right to kill one member of the other family. One of the families killed their daughter for getting pregnant outside marriage. It was expected that they would kill the boy who had seduced the girl. But the boy's family claimed the right to avenge the baby boy in his mother's body. Talking about the case, the doctor said.

"When all is said and done, if you think about it calmly, these are really simple matters," said the doctor [...] "Even this last case, which seems so dramatic, is really a question of the relations of creditor to debtor." (190, italic emphasis mine)

Each wound is paid for individually, and the price depends on the part of the body in which the wound is situated. [...] If someone wounds two persons in a family, or the same person twice, he becomes, by virtue of that fact -- he has not paid compensation for each of the two wounds considered separately - a debtor to the extent of all of one man's blood, which is to say a human life. [...] All that gives rise to extremely complicated problems, principally economic ones. There are families that are unable to pay the compensation for two wounds, and they choose to discharge the debt by taking a human life. There are others that are ready to ruin themselves, to pay for as many as twenty wounds received by the victim, in order to keep the right, once their victim is well again, to murder him. [...] I know a man who supported his family for years on the indemnities received from the wounds his enemies have inflicted on him. In this way, he created a new trade - that of making a living from his wounds. (192-193, italic emphasis mine)

Based on his observations, the doctor declared the economic nature of the Kanun prescriptions. In his words, the blood feud was simply a matter of creditor to debtor transformation. People who can afford the fines for wound compensation can keep their right for revenge killing. Gjorg, for example, failed to shoot his enemy to death for the first time, and according to the Kanun, in order to keep the right for killing, his family had to pay the victim's family half of the money for a human life because he wounded the victim's chin which was counted as part of the head. In other words, if Gjorg's family could not pay the fine for the wound, he had no right to kill the enemy but only to wound him for the second time on the head, and then he would become a debtor, a target for revenge killing by their enemy's family. The case that a man made 
a living from his wounds, though extremely rare, shows how blood feud became a trade business. In order to repudiate the saying that blood feud practice embodies social justice and fairness, the doctor collected facts for the anti-Kanun article entitled "Blood-feudology".

Often, behind the semi-mythical décor, you have to look for the economic component. Perhaps you'll accuse me of being cynical, but in our time, as with everything else, blood has been transformed into merchandise. (194)

Asked by Bessian if he had read Marx for holding such a view against the Kanun, the doctor just looked back as if asking whether Bessian had read Marx for asking such a question. Marxism, as can be seen, was behind the novel, playing an ideological role in exposing the true nature of the Kanun and constructing the Exploitative Other of the people of the Socialist Albania.

In every aspect of the events that were discussed today, it was purely a question of settling a debt. [...] Blood, precious stones, cloth, it makes no difference. To me, it concerns a debt, and that is all. (195)

With this in mind, it would be much easier for us to understand why the author emphasizes the details when Gjorg was hesitating whether he should eat a bowl of beans at the inn and repeatedly compare the amount of the money Gjorg could spend with the money set aside for blood tax.

He [the innkeeper] stared at the black band on Gjorg's sleeve, as if to say, "If you're about to pay five hundred groschen for the murder you did, the world won't come to an end if you spend a couple of them in my inn." (37)

Gjorg looked at him bewildered. His eyes seemed to say, don't tempt me. I may have five hundred groschen in my purse but I'd rather give you my head (Lord, he thought, that's just what it will cost me, my head thirty days from now, and even before thirty days, twenty-eight days), before time, than one groschen from the purse that's owing to the Kulla of Orosh. (37-38)

"Father, I'd like to go and wander around during the days I have left." [...]His father looked into his eyes for a long moment, 
saying nothing $[\ldots]$ He came down again in a few moments, a purse in his hand. Compared to the purse that had held the money for the blood-tax, it was quite small. (160)

Gjorg and his father represent the simple Albanian highland mountaineers living a hard life under the rule of the Kanun, unconscious of the exploitation made by the ruling class. Sometimes they would also ask themselves why they had to perform the endless revenge killing, but could not get the answer.

\begin{abstract}
All that torment, sleepless nights, the silent struggle with his father, his own hesitations, his brooding, his suffering, had brought about nothing more than these meaningless bare stones. He tried to leave them behind him, but he could not stir. The world about him began to dissolve swiftly, everything disappeared; he, Gjorg, and the cairn, were the only things left on the surface of the earth. Why? What had it all amounted to? The question was bare as the stones. It hurt him everywhere. (158)
\end{abstract}

The eternal theme of life and death is fully explored in the novel, leading the readers to meditate on the fundamental questions for human beings. The romantic but uncatchable love between Diana and Gjorg keeps the readers attracted till the end of the novel. Nevertheless, like all other works written by Kadare, it is more a political work than a romance or a work with philosophical implication. The central theme, as has been pointed out also by scholars like Klara Kodra, Pipi Mitrogjorgji, Dilaver Dilaveri, etc., is no doubt the impact of the Kanun on the people under its rule and the denunciation of Kanun's true nature (Tefik Çaushi 51-56). ${ }^{1}$ In Kastriot Myftaraj’s words, the novel presents the Kanun as a vampire sucking the blood of the people $(236)^{2}$

\title{
4.4 Discussion
}

This chapter has focused on two of Kadare's novels, namely The Wedding and

\footnotetext{
${ }^{1}$ See Tefik Çaushi, Universi Letrar i Kadarasë, Tirana: Dituria, 1993.

${ }^{2}$ Kastriot Myftaraj, "<Prilli i thyer> i Kadaresë - Reklama më e keqe për kombin shqiptar në botë” (Kadare's The Broken April - The worst advertisement in the world for the Albanian nation) in Gjyqi intelektual i Kadaresë (The intellectual court of Kadare), Prishtina: Buzuku, 2008, pp. 231-237. 
The Broken April, to see how Kadare presented the internal Other of Albanian nation in service of the political situation of the pertaining periods. Women's emancipation was achieved by clamping down the oppressive traditions and the institutions underpinning the oppressive mechanism, i.e. the Kanun and the religion. The Kanun was depicted as an evil oppressive spell hovering over Albanian weddings, whereas religion was blamed in the Wedding as the one which had a hand in prescribing the inferior social status of women. In The Broken April, while the oppressive role of the Kanun can be clearly perceived through its impact on Gjorg, it is the exploitative nature that Kadare aimed to expose. Kastriot Myftaraj criticizes Kadare for negatively presenting the image of the Albanian nation by fabricating the blood tax, which according to him has never existed in northern Albania. The blood steward Mark Ukacierra and the blood book which kept the record of the blood tax over centuries were also a horrible fabrication of the author in order to present the Kanun as a vampire. He further pointed out that instead of being resentful of the blood tax reduction caused the national uprisings against foreign occupation, as depicted in the novel, the Orosh castle played an important role in organizing uprisings against foreign occupations. It took an active part in the Prizren League in 1878, and contributed to the setting of the Prizren League's goal: the establishment of a unified Albanian national state (231-237). Then what was Kadare's purpose of fabricating the blood tax, blood book and blood steward? The anti-Kanun combat in Albania started right after the Communist Party came to power. Why did Kadare write such a novel in 1978? Does the appearance of The Broken April imply that Kanun was still effective after more than two decades of combat?

As for the first question, it is clear that the blood tax and blood book were fabricated to show how the state profits from the blood feud. It reflects Marxist 
perspective about how the ruling class uses the superstructure to keep the lower classes pliant. The levy of blood taxes and their records in the blood book was the most important part of what Kadare calls as blood-feudolgy. In a word, the fabrication is designed specifically to portray the Kanun as the exploitative Other of the Albanian nation.

To better understand why Kadare wrote about the Kanun in late 1970, we first need to note that Enver Hoxha put two things as his top priority: security and development. On the one hand, he had to secure his personal authority and the national sovereignty; on the other hand, he was ambitious to develop Albania into a modern industrialized country. In the early years of his rule, Hoxha focused on two things: domestically, he focused on expanding the control of the Communist Party to the northern regions where the Party enjoyed no strong support from the population; internationally, he managed to get out of Tito's control and gain more international recognition through Stalin's support. With the financial aid from the Soviet Union in the 1950s and from China in the 1960s, Albania saw rapid economic, social and cultural development during the two decades. In the 1970s, Enver Hoxha opposed China improving its relations with the United States because it was viewed as detrimental to Albanian national interests. Unable to find another great power which would be willing to support Albania to the extent as the Soviet Union or China did while posing no threat to Enver Hoxha's position or Albania's sovereignty, the Hoxha regime had to implement isolation policy. For the first time in its modern history, Albania did not have a foreign benefactor to support its viability. Luckily, in late 1970s, Albania's economic situation made such a self-reliant policy possible, though without challenges and hardship. What Enver Hoxha said on the Seventh Congress of the Albanian Labor Party in 1976 demonstrated the government's confidence in its 
ability of maintaining self-sufficiency: "The old Constitution was the constitution of the building of the foundations of socialism, whereas the new Constitution will be the Constitution of the complete construction of the socialist society". ${ }^{\text {At }}$ a time when the world order was readjusting, Albania's isolation strategy entailed a tougher domestic control to maintain its political stability. Furthermore, the poor health condition of Tito in late 1970s drove Albania to prepare for the political uncertainty in Yugoslavia after Tito's death. The Albanian government had to think ahead of the challenges that might appear in their efforts to solve the Kosovo problem. Therefore, to keep his absolute power in the country and to weaken the Kanun's influence in the Albanian northern region and Kosovo turned out to be extremely important for Enver Hoxha. A careful reader might have noticed that there are quite a few places where the author reiterates Kosovo as an integral part of the High Plateau under the rule of Kanun. In short, The Broken April was created to support Albania's choice of self-reliance policy, its efforts to consolidate rule in northern Albania and its preparation to solve the Kosovo problem. The fact that Kanun became the target for attack during the Albanian communist era reflects the need for engaging women in the socialist construction and raising their educational level to meet the demands of a modern country, the need for keeping Enver Hoxha in power, as well as the need for establishing absolute authority in the Northern High lands, including Kosovo.

One thing worth mentioning is how Kadare treated in his novel entitled Spring Flowers, Spring Frost (2000) the phenomenon of the Kanun's revival in Albania in late 1990s. The Albanian communist regime was accused for the reappearance of blood feud because, according to Kadare, it did not allow the Kanun to die a natural death.

\footnotetext{
${ }^{1}$ Enver Hoxha, Report on the Activity of the Central Committee of the Party of Labor of Albania, Tirana: 8 Nëntori, 1977, p. 12.
} 
A vendetta coming back to life after lying dormant for fifty years [...] It was probably the Kanun's last spasm, its dying effort to come up to the surface, along with everything else that had been pushed down to the bottom by the prohibitions of the Communist era. At the turn of the millennium, the Kanun had outlived its natural life span. It would have died a natural death long ago had it not been banned by the Communists. Their attempt to suppress it was the only reason this madness had acquired new life. (73-74)

In this way Kadare denies the achievements of the anti-Kanun combat during Hoxha's regime. In other words, he dismantled in Spring Flowers, Spring Frost the Kanun Other constructed by himself in his previous works.

Scholars are concerned about the revival of the Kanun after the collapse of communist regime in early 1990s. For example, many worry that "when Albania is enfolded into the EU, it will bring with it the concept of the kanun, or blood-feud, which seems to be an ineradicable element in Albanian social culture". ${ }^{1}$ The word "revival" suggests that the Kanun died out in Albania during the communist regime. It remains to be discussed whether the Kanun was totally uprooted by the Albanian communist regime. But different from Kadare's interpretation of the Kanun's revival, "legal experts in Albania say the feuds erupted again after the fall of Communism ushered in a new period of lawlessness,", in other words, "If you have the kanun structure today, it means the state is not working". 3

The toughness of the anti-Kanun combat is made clear by Kadare in The Broken April.

The [Orosh] castle itself had neither a police force nor governmental powers, but the High Plateau was nonetheless wholly under its control. That had been true in the time of the Turks, and even earlier, and that state of affairs had gone on under the Serbian occupation and the Austrian occupation, and then under the first republic, and the second, and now under the monarchy. Some years ago a group of deputies tried to put the

\footnotetext{
Richard Pine, “Albania's deadly tradition of blood feuds as pervasive as ever," Irish Times, Jun 26, 2009.

2 Dan Bilefsky, "In Feuds, Isolation Engulfs Families," The New York Times, July 10, 2008, p.6.

3 Jeffrey White. "Peacemaker breaks the ancient grip of Albania's blood feuds", Christian Science Monitor, 08827729, 6/24/2008, Vol. 100, Issue 147.
} 
High Plateau under the authority of the national government, but the attempt failed. (119)

"How many governments have fallen," the prince had gone on, "And how many kingdoms have been swept from the face of the earth, and Orosh is still standing." (132)

Why can the Kanun survive and revive again and again? Toward the end of the novel Spring Flowers, Spring Frost, Kadare seems to offer another explanation. The former Albanian leaders Enver Hoxha and Ramiz Alia, and leaders of other communist countries such as Leonid Brezhnev and Walter Ulbricht are presented as searching for the blood book, the list of all blood feuds, because "Every tyrant is a potentially infinite sequence of crimes. On the very day that a tyrant seized the crown, those crimes are transferred from the future, from what is yet to come, to the past, to its furthest reaches (Spring Flowers 180-181)". Indeed, while Enver Hoxha was fighting against the Kanun, he himself, as noted by Bernd Fischer in his video program "Enver Hoxha, the Little Stalin of Albania", also ruled the country with clan ideology. By adapting the clan tribal structure to the Party, Enver Hoxha became the chieftain of his political clan who had the right to decide where blood feud would be applied. ${ }^{1}$ In other words, while combating the Kanun, Enver Hoxha inherited the Kanun spirit and used it maintain his political position. Today, the Kanun culture is not only an integral part of the ordinary Albanian people's life ${ }^{2}$ it is a notable feature of the Albanian political ecology over the past two decades of transition from dictatorship to democracy.

The blood book we got to know in Broken April reappeared in Spring Flowers,

\footnotetext{
1 Please refer to http://www.youtube.com/watch?v=aSpV6LtN4Ds 2009 IPFW Featured Faculty -- Bernd Fischer - YouTube, accessed Dec. 18, 2012. Bernd Fischer said this around the $23^{\text {rd }}$ minute of his 58 minute-lecture.

2 "Ismet Elezi, a professor of criminal law at the University of Tirana, who advises the government and the police on how to tackle the problem, said recent changes to Albania's penal code -- including sentences of 25 years to life in prison for those who kill in a blood feud and stiff penalties for individuals who threaten to retaliate -- had helped diminish the practice. Yet he noted that some still gave greater credence to the Kanun than to the criminal justice system, often with devastating social consequences." quoted from Dan Bilefsky, "In Feuds, Isolation Engulfs Families," The New York Times, July 10, 2008, p.6.
} 
Spring Frost, in the discussion of whether and where it still exists.

What was known of the fate of the Book of the Blood up until World War II was generally consistent; but what had happened to it thereafter was the subject of widely divergent stories. When they came to power in 1945, the Communists burned down the Castle of Orosh, where the book had been kept for many centuries. At first it was supposed that the book had turned to ashes along with a part of the archives of the prince of Orosh, but soon after a different supposition came to circulation, namely, that the Book of the Blood had been stashed away safely somewhere else. That seemed all the more plausible when the suspicion that the Communists had gotten hold of it and destroyed it themselves turned out to be unjustified. After all, if the winning side had gone so far as to preserve the historical records of land ownership, it was hardly likely that it would have suppressed a mortal inventory. [...] For the Communists, property was a threat far greater than death! (78-79)

This passage actually tells us that apart from the Kanun, those who had private property were a bigger threat to the communist regime. This internal Other consisting of the former property owners was clearly presented by Kadare in his novel The Great Winter. The owner of an antique store had witnessed like a seismograph all the political changes of the country since 1944 (254). When it was rumored that Albania might turn to the West, the former ruling class members showed up in his store to buy back their old things, such as priest's costume, belt, etc. It indicates that the former property owners whose properties were confiscated by the communist regime were hoping secretly for the country's Westernization after its break with the Soviet Union. Represented by the old woman Nurihan and his friends, they represent a potential threat to the Albanian nation in its socialist building.

It had been a long time that she had not listened to the radio. For her, the cities of the world, whose names were marked on the rectangular radio, had died long ago. It was the same for most of her friends. Paris, Vienna, Luxemburg, Madrid, all the names were covered by dust. And she didn't want to mention their names, just like those who don't want to mention their beloved people's names when they are no more living. However, two days ago, Musabelliu, the old friend of their family, came to tell her something unusual. With trembling voice, he told her how one 
night before he, while searching for the foreign station, accidentally extracted a diamond from the noisy and hubbub words. It was an ordinary piece of news, seemingly unimportance: Albania, the smallest country in the socialist block, had bought grains from France. (Dimri $i$ vetmisë së madhe, 119-120) ${ }^{1}$

The depiction of the dreams of old property owners and their psychological change caused by the deterioration of Albanian-Soviet relations occupies a considerable part of the novel. Taking into consideration that Kadare wrote the novel in 1971, a time when China and USA started to normalize their relations, we can better understand why Kadare made such a design. It aimed to warn the people that the clamped old class was a dangerous group from within who were awaiting opportunity to return to their old good days.

Talking about the internal Other, The Three-Arched Bridge should not be ignored, though its major theme is not about the internal Other. In the novel, the local lords were presented as traitorous Other of the nation, who would not hesitate to sell the nation for their personal interests. They were the internal Other of the nation also because of their constant quarrels which led the nation to nowhere but fragmented.

The count's thoughts were clearly wandering from his empty exchequer to his sick daughter, and the bridge these strangers were offering was the sole remedy for both. [...] Our count did not think matters over for long. He said that he accepted the agreement. (12)

Quarrels among the Albanian princes and lords have been hopelessly frequent for the last hundred years. [...] Almost all the lords of Arberia had gone to the ceremony, but apparently not even the sight of the old prince's coffin, around which they were all gathered perhaps for the last time, gave them the wisdom to finally reach an understanding among themselves. $(43,147)$

The monk Gjon who told the story in the first person about the construction of the bridge is also depicted as an internal Other, because he semi-consciously helped with

\footnotetext{
${ }^{1}$ Ismail Kadare, Dimri $i$ vetmisë së madhe (The winter of great solitude), in Kadare vepra, vëll. 5 (volume 5 of Kadare works), Tirana: Onufri, 2008.
} 
the Ottomans' arrival. Moreover, as we later learned from the novel The Palace of Dreams, though Gjon repeatedly expressed his disgust toward the Ottomans and his fear of the imminent Ottoman occupation, he quickly changed his attitude. Not only did he change his surname into Quprili, which derived from the Turkish word for bridge "köprü", but ironically, his descendants became powerful officials in service of the Ottoman Empire.

All in all, analyzing Kadare's works, we can see different internal Others constructed, including the Kanun, the religious agents, the former property owners, the rulers prior to the communist regime, etc. They were presented as oppressive, exploitative, traitorous, potentially rebellious, and so on, in order to portray in contrast the greatness of the Communist Party. In a word, the construction of the internal Others served to maintain the Party's authority and the domestic stability. Moreover, in his works, we can also find profound influence of Marxism and Albania's relationship with foreign countries. That is to say, the internal Others constructed in Kadare's works reflect both Albania's domestic situation and the international political situation. 


\section{CHAPTER 5 THE NEIGHBORING OTHER}

\subsection{Background}

When the issue of the neighboring Other of the Albanian nation is concerned, one would naturally think of Italy, Greece and the former Yugoslavia (Serbia and Macedonia after Yugoslavia's disintegration). Italy, the representative of the West, was an Other in The General of the Dead Army, as discussed in Chapter Two; Greece, has never been treated as an Other in an ad hoc novel by Kadare, though it has occasionally been mentioned or alluded as so in his works. ${ }^{1}$ Only the Slavs, to be more specific the Serbs, have been targeted in many of Kadare's classic works as the Albanian nation's Other. This chapter examines from three perspectives how Kadare has presented Serbia as a serpent and evil Other of the Albanian nation, namely the colonialist Other, the criminal Other and the irreconciliable Other.

The Albanian Epos, otherwise called the cycle of heroes, is a series of poems in which the Albanian resistance and struggle against the Slav incursion stands out as the predominant theme. The very existence of the Epos points to the old conflicts and enmity between Albanians and Slavs. However, it is in the modern time when the Balkan nationalisms arose and each nation was trying to gain its biggest national interest from the Ottoman heritage that the two neighboring nations, i.e. Albanians and Serbs, are locked in mutual hostility until today.

\footnotetext{
${ }^{1}$ For example, in The File on $H$., the governor was suspicious of the Harvard scholars' purpose of visiting Albania, doubting that they got instructions from their university, i.e. the U.S. or from some office of the Greek Intelligence Service. (The File, 44).
} 
The 1830s saw the start of the Albanian National Revival Movement, in which the Albanian national renaissance pioneers endeavored to form a unified literary language and to establish a nation state of their own. When the Ottoman Empire was forced to retreat from the Balkans, the local Balkan nations were all striving to win the great powers' support for their national cause. Bulgarians and Serbs gained autonomy or independence with the help of their big Slav brother Russia. Albanians, unfortunately, were identified with Turks due to its Islam affiliation. After Turkey's defeat in the Russo-Turkish wars, Albanians feared that the lands they inhabited would be partitioned among the neighbors. The San Stefano Treaty in 1878 spurred the Albanian national renaissance leaders to take steps for self-defense. On June 10, 1878, about eighty delegates from the four Albanian-populated vilayets met in Kosovo and established the Prizren League. A month later, the League sent a memorandum to the Congress of Berlin, which was convened to settle the unresolved problems of Turkish War. The demand of the Albanians that they be united into a single province was ignored. The German chancellor Bismarck even proclaimed that Albanian nation did not exist. At the Conference, some of the territories considered by the Albanians as theirs were ceded to the neighboring Montenegro and Serbia. Though the Prizren League was short-lived, it succeeded in making the great powers aware of the will of Albanian people and their national interests (Historia e Popullit Shqiptar, 226-228). ${ }^{1}$

The First Balkan War erupted in October 1912, launched by the anti-Ottoman Balkan League to end the Ottoman rule in the Balkans. The Balkan allies - the Serbs, Bulgarians, and Greeks - quickly drove the Turks back to Constantinople. Meanwhile, the Montenegrins surrounded the Albanian northern city Shkoder; the Serbs took

${ }^{1}$ Skënder Anamali, Kristaq Prifti, Instituti i Historisë, Akademia e Shkencave e RSH (History Institute of the Albanian Sciences Academy) Historia e Popullit Shqiptar II - Rilindja kombëtare: vitet 30 të shek. XIX-1912 (History of the Albanian People, vol. II, National Renaissance, 1830s -1912 ). Tirana: Toena, 2002. 
much of northern Albania, and the Greeks captured parts of southern Albania. It was at this critical moment that Albanians declared their independence, on November 28, 1912. Hoping that an independent Albania would contribute to the balance in the Balkans and decrease Russia's influence in the region, in 1913 the Great Powers opted to recognize the new Albanian state under their protection. The 1913 Treaty of Bucharest set up the present Albanian borders, leaving large areas with majority Albanian populations, notably Kosovo and the Western Macedonia, outside the new state.

Over the past 100 years, Albanians have never forgotten the goal set by their national revival pioneers. National unity is the ultimate purpose of every patriotic Albanian, no matter where he resides, in Albania proper, in Kosovo or in Macedonia. The loss of the Albanian-inhabited territories, Kosovo in particular, has been the incurable pain for the Albanian nation. The anti-Serbian sentiment was strengthened because of Serbian government's anti-Albanian policy: in addition to colonization policy of settling thousands of Serb families in Kosovo, the Belgrade government also resorted to mass expulsion of the Kosovo Albanians. In 1937, Vaso Čubrilović expressed his view in a memorandum: "In our examination of colonization in the south, we hold the view that the only effective means of solving this problem is the mass expulsion of the Albanians. Gradual colonization has had no success in our country, nor in other countries for that matter. If the state wishes to intervene in favor of its own people in the struggle for land, it can only be successful by acting brutally" (Quoted from Elsie). ${ }^{1}$ From 1918 to 1921, the expulsion reduced the number of Albanian population in Kosovo from around one million to about 439,500 (Ramet:

\footnotetext{
${ }^{1}$ Robert Elsie. Gathering clouds: the roots of ethnic cleansing in Kosovo and Macedonia. Peja: Dukagjini Balkan Books, 2002. The Čubrilović memorandum, "The expulsion of the Albanians" is republished by Elsie, accessible at http://www.elsie.de/en/books/b29.html.
} 
$198)^{1}$. In 1938, Yugoslavia and Turkey reached an agreement, according to which, if not stalled due to the outbreak of WWII, 40,000 Kosovo ethnic Albanian families would be transferred to Turkey. Therefore as long as opportunities appear for national unity, the Albanians would opt to cooperate with those who would support their national cause. Kosovo Albanians made numerous resistance movements against the Serbian rule. Right before WWI, Hasan Prishtina formed the Committee for the National Defense of Kosovo, which lobbied with the US and other western governments for the inclusion of Kosovo in the new Albanian state. Isa Boletini, Bajram Curri etc. also organized armed rebellions and became heroes in the eyes of the ethnic Albanians. "It is clear that, overall, the kaçak movement was a political phenomenon, directed against Serbian rule as such, and it is also clear that the anti-Albanian policies of the government and local authorities (including the whole colonization programme) were a powerful stimulus to the rebellion" (Malcolm 1998: $273)^{2}$

During WWII, Kosovo was annexed into Albania under fascist rule. This was naturally welcomed by the Albanians and there ensued Albanian retaliations against the Serbs. After WWII, Kosovo was retaken by Yugoslavia and the Albanian nationalists were suppressed. In the years after the war numerous Albanians were killed, persecuted and forced to leave their lands. Though the situation of the Albanians in Kosovo improved after Alexander Rankovic was purged by Tito in 1966, the Albanian-Serbian mutual enmity did not get eliminated. It faded away in late 1960s and throughout 1970s under the slogan of "brotherhood and unity" but came back in 1980s after Tito's death.

\footnotetext{
${ }^{1}$ Sabrina Ramet. Social currents in Eastern Europe: the sources and consequences of the great transformation. Durham: Duke University Press, 1995.

${ }^{2}$ The word kaçak is an originally Turkish term for rebel or bandit. In Albanian dictionary, the term is defined as a fighter against social injustice, the exploiting class or foreign invasion. The kaçak movement refers specifically to the fighting in Albanian inhabited areas against foreign rule during the Albanian National Awakening and the early 20th century in Kosovo. See Noel Malcolm, Kosovo: A Short History. London: Macmillan, 1998.
} 
Kadare, like all the other Albanian intellectuals who wish to carry on the cause of the National Revival, has always been concerned about the Kosovo problem. This can be seen from his short poem "Kosovo", written in 1966, where he expressed his concern about the fate of Kosovo Albanians. ${ }^{1}$ However, Kadare's concern for and attitude toward Kosovo were restricted and influenced by the political climate. In other words, what Kadare writes about Kosovo reflects Albania's policy toward Kosovo and is closely related to the relationship between Albania and Yugoslavia, as well as the Balkan policy of the great powers.

After the Second World War, Albanian Communist Party came to power with the help of Tito's Yugoslavian Communist Party. The Albanian-Yugoslavian friendship was the major political theme, which temporarily left aside the Kosovo problem. Even after the split with Yugoslavia, Albania did not take initiative to provoke Yugoslavia on the issue of Kosovo. This policy remained so until early 1980s, partly due to Hoxha's communist international ideology and partly due to the lack of international support and the incapability of Albania in fighting against Yugoslavia. However, Albania changed its cautious attitude after Tito died in 1980. After several decades' indoctrination of the Albanian national identity in Kosovo, and as a response to the Serbian nationalism, Hoxha's regime found it the right time to claim its historical right to Kosovo and to openly support the nationalist movement in Kosovo. All this is reflected in Kadare's works on Kosovo, from which we can see the same change, from being almost mute till early 1980s to gradually open denouncement of Serbian nationalism and claiming historical right to Kosovo. It is worth noting that Kadare's short poem mentioned above was written at the time when the Rankovic clique was

\footnotetext{
${ }^{1}$ With touching pathos, the author expresses his feelings when he was flying over Kosovo. Lightning, rain, cloud and thunder were used to transmit certain messages. At the end of the poem, the author presents a sad picture: "We are progressing, but you are left behind. The wings of the plane cut you into thousands of pieces." See the original text in Bashkim Kaçuku, Antologjia e poezisë shqipe bashkëkohore (Anthology of the Contemporary Albanian Poetry), Tirana: Onufri, 2008, p. 204.
} 
being purged by Tito and right before Kosovo Albanians demonstration in 1968 asking for Kosovo Republic. But even in a tense situation like that, Kadare didn't touch upon the sensitive problem of who has the right to own Kosovo. The fact, as professor Shaban Sinani pointed out to me, that not only Kadare but all the Albanian writers did not produce literary work with regard to Kosovo further proves that the Albanian intellectuals' writing on Kosovo has also been a politically oriented job.

Kadare's literary works concerning the Kosovo problem are produced in two major time periods: the first is from early eighties to mid-eighties and the second in the last few years of the nineties. This phenomenon is closely linked to the political situation of the relevant time. After Tito's death, with no one powerful to control the whole country, Yugoslavia entered a new political scenario. Six republics and the two autonomous regions including the one of Kosovo formed a collective leadership and took turns to be the head of the presidency on an annual basis. The 20 billion US\$ foreign debt brought Yugoslavia into economic crisis and the conflict of interests of different republics and autonomous provinces became increasingly irreconcilable. Ethnic strains which were coerced during Tito's time reappeared, especially the conflict between Serbs and other ethnic groups as a result of the intensification of the Serbian nationalism. In Kosovo, the Albanians were not satisfied with their living conditions and political discrimination against them in power distribution, employment, housing, etc. They wanted to end the policies in favor of the Serbs and have their own say on critical matters. There was an upsurge of anti-Serbian sentiment which led to the demonstrations in 1981. This time, Albania's voice changed dramatically, which can be seen from Kadare's publication of Dosja H. (The File on H., 1981), Viti i mbrapshtë (The Dark Year, written between 1981-1983, published in 1983) and Krushqit janë të ngrirë (The Wedding Procession Turned to Ice, written 
between 1981-1983 and published in 1986). ${ }^{1}$ Of course, the above three works do not only indicate the official adjustment of Albania's policy toward Kosovo, they are also, on the other hand, an eruption of Kadare's long-suppressed feelings on the Kosovo issue.

The death of Enver Hoxha in 1985 liberated Albania from dictatorship. Though his successor Ramiz Alia was still following the political course designed Hoxha, he started to implement a policy which was relatively more open and allowed more freedom. Toward the end of 1980s, the communist regimes in the other East European socialist countries collapsed one after another, which endangered the existence of Albanian communist government. The Kosovo problem was laid aside by Alia's government, which was in no way in condition to free itself from domestic troubles and support Kosovo's struggle for the status of republic. The same can be said for Kadare, who was too busy taking care of his personal identity in the new political circumstances and found no time to write in support of Kosovo. It was not until 1998 that Kadare produced a new book with regard to the Kosovo problem named Tri këngë zie për Kosovën (Elegy for Kosovo), which was followed by Ra ky mort dhe $u$ pamë (Death Befell and We Saw Each Other, 1999), another work on Kosovo problem written in the form of diary, reflections and letters.

After the Kosovo War in 1999, Kosovo gradually moved to independence. In 2008, with the help from the U.S. and the majority of Western countries, Kosovo declared its independence. However, the Western support was not without condition: Kosovo had to promise not to reunite with Albania. What does one nation two separate states mean to Albanians? How should the flags be used, the newly designed

\footnotetext{
1 The publication of this novel was delayed by the Albanian government due to the concern that it would be used by Serbia as evidence for Albania's meddling in the Kosovo demonstrations and it would meantime put Sahadete and Esad Mekuli family (the model for the Shkreli family in the novel) into danger. The English version is translated by Robert Elsie and published as "The Wedding Procession Turned to Ice", in, R. Elsie ed., Kosovo - in the Heart of the Powder Keg, pp. 105-192, 1997.
} 
one of Kosovo flag with six white stars and golden Kosovo map on a blue field, and the traditional Albanian national flag with a black eagle and a red field? How to describe the Kosovo identity and the Albanian national identity as a whole? How these questions must be dealt with and await wise answers from the Albanian elite so that the Albanian nation can survive and progress as a whole in the era of globalization. Unfortunately after entering the 21 st century, Kadare has produced no literary creation with regard to Kosovo's identity. His essay “The European Identity of Albanians" in 2006 argues that Islam is the Other that the Albanian nation should distance from in the process of returning to Europe. Serbia, which had been always appeared in Kadare's works as the Other till the end of the twentieth century, faded away from Kadare's target, though Serbia is an inevitable and critical factor for Kosovo's future.

\subsection{The Colonialist Other}

In his work Colonialism: A Theoretical Overview, Osterhammel defines colonialism with three sentences, the first two of which are

Colonialism is a relationship between an indigenous (or forcibly imported) majority and a minority of foreign invaders. The fundamental decisions affecting the lives of the colonized people are made and implemented by the colonial rulers in pursuit of interests that are often defined in a distant metropolis. (16) ${ }^{1}$ (italic emphsis mine)

To paraphrase it, colonialism is in nature the colonizing nation's pursuit of their national interests by means of the extension of its sovereignty over a territory where the indigenous people occupies the majority. In other words, whether the ruled people

\footnotetext{
1 The third sentence of the definition is "Rejecting cultural compromises with the colonized population, the colonizers are convinced of their own superiority and their ordained mandate to rule". It is more pertaining to how the West Europeans imagined an colonial Other to maintain their superiority. See Jürgen Osterhammel. Colonialism: A Theoretical Overview. Trans. Shelley Frisch. Princeton: Markus Weiner Publishers, 2005, p. 16.
} 
are indigenous majority is essential in determining its colonial status.

The Kosovo problem revolves aound the legitimacy of Serbia's rule over the majority of ethnic Albanian Kosovars. Serbs oppose being labeled as colonialists in Kosovo, arguing that Kosovo was essentially uninhabited when the Slavs arrived in the sixth century. They even accuse the Albanians as interlopers who took advantage of the Ottoman support to move into the area in the 17th-18th centuries. By mythicizing the 1389 anti-Ottoman Kosovo War, the Serbs claim Kosovo to be the root of their national civilization and national identity. On the other hand, the Albanians claim that they are the indigenous people, envoking all historical, ethnographical and lingustic evidence to prove that they are the descendants of the ancient Dardania people, an Illyrian tribe which inhabited the present Kosovo (Vickers: xiii, 3,4$){ }^{1}$

Kadare, the most prominent Albanian writer, has played an extremely important role in strengthening the image of Serbia as the colonialist Other. For example, in The Three-Arched Bridge, he stated the indigenousness of Albanian people through the monk's mouth, in his conversation with a monk from Europe:

When I told him that we Albanians, together with the ancient Greeks, are the oldest people in the Balkans, he held his spoon thoughtfully in his hand. We have roots here, I continued, since time immemorial. The Slavs, who have recently became so embittered, as often happens with newcommers, arrived from the steppes of the east no more than three or four centuries ago. I knew I would have to demonstrate this to him somehow, and so I talked to him about the Albanian language, and told him that, according to some of our monks, it is contemporary with if not older than Greek, and that this, the monks say, was proved by the words that Greek had borrowed from our tongue. (70)

Also in The Palace of Dreams, the author took every chance to indicate that Kosovo belonged to Albania, before it was grabbed by Serbia.

\footnotetext{
${ }^{1}$ Miranda Vickers. Between Serb and Albanian: A History of Kosovo. New York: Columbia University Press, 1998.
} 
His imagination was filled with a vision of the plain of Kosovo in northern Albania, where he had never set foot. [...] And here again were pools of blood [...] And that is why, O Allah, in any kind of weather, winter or summer, in wind or silent rain, that plain there in northern Albania ... $(134,136)$

The same indication can be found repeatedly in Broken April. Among the many examples we can mention the following three:

The $\operatorname{Rrafsh}^{1}$ is the region of Europe which - while being an integral part of a modern state, an integral part, I repeat, of a modern European state and not the habitat of primitive tribes has rejected the laws, the legal institutions, the police, the courts, in short, all the structures of the state. (72)

All the endless expanse of the Rrafsh, which began in the heart of Albania and reached just beyond the frontiers of the country. All of the high Plateau, to which in a sense he was linked by the fact that the blood taxes came to him from everywhere, was nonethelss an enigma. (142)

He had always thought that he knew his Rrafsh, of which it was said that it was one of the largest and most sombre of the high plateaus of Europe, and that besides spreading over thousands of square miles in Albania it went beyond her frontiers, through the Albanian districts of Kosovo, those that the Slavs called "Old Serbia", but were really part of the High Plateau. (145)

Then, in his novel The Dark Year (1983), which is based on the historical events between 1913-1914, an omnious and turbulent year for Albanians, Kadare made this sovereignty claim even more clear. Toward the end of the novel, the ghost of one of the protagonists appeared, and, raising his crutches, showed his body which was missing one arm and one leg. "Don't you understand? Albania has been amputated, just like me. Don't you know?!” he cried out loudly (Koha e shkrimeve, 363). ${ }^{2}$ Here, the missing arm and leg refer respectively to Çamëri ${ }^{3}$ to the south of Albania and

\footnotetext{
1 Albanian word for plateau.

${ }^{2}$ The Dark Year was first published in 1986 Koha e shkrimeve (Epoch of Writings), pp. 270-363, by the Naim Frasheri publishing house in Tirana.

${ }^{3}$ Çamëria is a geographical name in Albanian for parts of the coastal region in southern Albania and northwestern Greece. During the Ottoman rule, the region was under the Vilayet of Ioannina and in the 18th century when the Ottoman power was in decline, the local governor Ali Pasha of the Albanian origin rebeled and gained semi-independence. In 1913, following the Balkan wars, the London Conference gave the majority part to Greece, leaving only a small portion to the newly formed Albania. As a result of the expulsion of the Muslim
} 
Kosovo to the north of Albania.

Nevertheless, it is in The File on H. (1981) that Kadare most artfully accuses Serbia of manipulating cultural heritage to legitimate its colonial rule over Kosovo. The novel looks like a detective story but is a political one in essence. The creation of The File on $H$. is said to be inspired by Kadare's conversation with an Americal folklorist scholar Albert Lord, who together with his colleague Milman Parry went to the Yugoslavian mountainous areas in the 1930s for field research on the Serbian ballads. They had collected numerous materials which they used to prove the antiquity and originality of the Serbian folk songs. Kadare was upset by what he had been told and therefore decided to write The File on $H$., in order to tell the world that despite the existence of two versions of the same ballads, one in Albanian and the other in Serbian, only the Albanians are the true author of the epic poetry which is as old as the the homeric epics. In other words, Kadare wanted to denounce Serbia's attempt of stealing the Albanian epics and making it their own cultural heritage. By arguing about the ownership of the epics, Kadare is actually providing the historical evidence for the Albanian national identity and proclaiming Albania's territorial right to Kosovo.

The novel narrates the field research experience of two young Irish American scholars in northern Albania in the 1930s during the Albanian King Zog's reign. They went to Albania because they heard that the area "covering the whole northern zone of Albania but extending also into parts of Montenegro and reaching a few parts of Bosnia, inside the Yugoslav border [...] is the only place in the world where poetic

\footnotetext{
Albanians of the region after the Second World War and the Greek assimilation policy, Çamëria is nowadays inhabited mostly by Greeks. Disputes still exist between Greece and Albania, but not on the level of the territory claim. The Albanians argue that the expelled Albanians should have the right to return to Greece and their properties confiscated should be returned as well, whereas Greece says that the Albanians were expelled according to the Greek law because they collaborated with the Italian and German forces during WWII. In the recent years, Greece also accuses Albania for not granting enough human rights to the Greek minority in southern Albania.
} 
material of the Homeric kind is still being produced" (40-41). Before they arrived at the city of N. in northern Albania, the governor of the city had already received a letter from the Interior Minster telling him that take care of the two guests, who alleged themselves to be folklorists but were apparently spies. The governor's wife was extremely interested in the foreigners. Bored of her life, she daydreamed of an affair with one of scholars from the West named Bill Norton. When she got to know that the scholars were not staying in the town but going to settle down at a remote inn at the southern foot of the Dukagjini Plateau, she was very disappointed. Nevertheless, she was fond of them. She was astonished to learn that her husband had put the foreigners under surveillance. In an attempt to protect the two scholars, she made a fool of herself: she slept with the spy dispatched by Tirana.

Bill and his friend Max had no idea that they were being watched 24 hours by the secret service. They viewed themselves as purely Homeric scholars who wanted to explore how Homer's epics were created, memorized and carried down generation after generation. They wanted to be far away from small-town society calls and be left in peace to do their research. The Buffalo Inn where they were staying was a nice place for collecting live materials of the Albanian epic songs, for it was one of the places where the rhapsodes usually stayed on their way to and fro the Highlands. The innkeeper was very helpful. He assured them that rhapsodes would stop over at his inn, at least twice in every month, and there should be no problem for listening twice to the same rhapsode because most of the rhapsodes would come back in two weeks after they finished their job at a wedding or a funeral. The only thing he was not sure was whether the rhapsodes would agree to sing in front of the machine. Bill and Max had brought with them a modern device for their research: a tape-recorder.

Luckily four days after they settled at the inn, the first rhapsode showed up and 
the innkeeper successfully persuaded him to sing for the two Irishmen. When the machine reproduced the rhapsode's voice, the audience was struck dumb. They could not believe how a man's voice could be stored inside a box like that. Though the rhapsode promised to sing the same two songs on his way back two weeks later, Bill was afraid that he might find a a bad omen to have his voice locked and trapped in a box and thus change his mind. In the days afterwards, other rhapsodes appeared and sang different ballads, one of which they had dreamed of hearing ever since they had first got interested in Albanian epic. Irishmen even saw the ancient ritual gesture they had read about in scholarly literature. They were happy that everything went on well with the recording and transcribing. The only thing they kept reminding themselves was that they should not bury themselves in the world of Albanian epics and lose sight of their main aim, i.e. to solve the enigma of Homer.

However, the more they delved into the Albanian epic world, the absorbed they became. Looking for the most recent event that had been turned into ballad, they found twelve lines referring to the Congress of Berlin of 1878. But why 1878 ? They were even more astonished to find only one line in the oral epics for 1913, the black year of Albania's dismemberment. In the course of their work, they came to understand that their research was actually touching upon the national interest of the two neighboring nations, the Albanians and the Serbs. Despite their claim that they were merely interested in the production process of Homer's epics, the Irishmen got inevitably involved into the Serbian-Albanian conflict.

The Irishmen's story in Albania was reported by the U.S. newspapers, in headlines such as "Is this the end of the Homeric question?", "A bizarre adventure in a land believed to be the last extant cradle of Homeric poetry" etc. Shortly after the 
reports, a Serbian monk named Dushan from the archdiocese of Peja ${ }^{1}$ came to visit the scholars. He was very angry to discover the nature of the scholars' work, i.e. in an attemp to discover the enigma of Homer through the study of Albanian epics, they were indirectly doing the Albanian people a great honor, to the detriment of the Serbian nation. The monk hastened away, heading for the retreat of an Albanian hermit named Frok. He told Frok about the Irishmen's ongoing work and made him believe that the Irishmen, with a satanic device, were imprisoning and robbing away the most precious property of the Albanian nation. Enraged by the monk's words, Frok led a gang of people to attack the Buffalo Inn, in order to save their national treasure. They injured Bill, broke the tape-recorder and destroyed all the tapes. What Bill and Max were afraid of when they saw suspicion and fear in some highlanders' eyes finally occured. They returned home empty-handed. The big honor they were doing indirectly to the Albanian nation was eventually not realised. But to their astonishment, they saw in the newspaper that their work had been turned into an epic poem. And Bill Norton, who had completely lost his sight, became a modern Homer singing the Albanian epic, with the ancient Homeric ritual gesture.

In The File on H., Serbia as the colonialist Other is constructed basically on the arguments that the Albanians are the Balkan natives and the Serbs as the late comers did not only grab the Albanian territory of Kosovo and but also attempted to legitimate its rule over Kosovo by claiming the ownership of cultural heritage. In other words, the quarrel between the Albanians and the Serbs over the epic is not simply an issue of cultural heritage, rather, it is a fundamental political issue of who has to right to own Kosovo. That's why the Irishmen were warned by the American

\footnotetext{
${ }^{1}$ Peja is in Kosovo and used to be the Patriarchate of the Serbian Orthodox, till the end of the seventeenth century, when Patriarch Arsenios III removed his seat to southern Hungary to escape the severe Turkish repression. After the Second World War the Patriarchate of Peja was converted into a convent. It is considered by the Serbs as their most important medieval monastery.
} 
consul in Tirana not to take sides in arguments.

In this country, disagreements rapidly escalate into armed conflicts. Especially if what's at stake is the ancestry or the paternity of epic poetry. Both sides treat the question as a fundamental part of the national issue and connect it to ethnic origins, to historic rights over Kosovo, and even to current political alliances. (112)

Actually, the Irishmen had been informed of the Kosovo problem before they set out for Albania: Kosovo used to be part of the Albanian territory ever since the ancient time and though inhabited by half of the population of the Albanian nation was occupied by the Slav invaders originally from Asia. Moreover, they learned that epic was viewed by the Albanians as one of the principal treasures endowed to the their nation. By this arrangement, Kadare aims to highlight the tragedy of the Albanian nation and the importance of the ancient Albanian epic.

We are also learning more and more about Albania. A small country with an ancient population. Tragic history. To begin with, a European country. Then Asian overlords. Return to Europe in the twentieth century. Half of all Albanians live outside the current borders. Apart from the epic which constitutes its principal treasure, in our view, Albania also has chrome and oil. (49)

Soon after they settled down, the Irishmen found out that the epics exist in the both Albanian and Serbian laugages. And both sides, the Serbs and the Albanians, were using the epic as a weapon against the other.

For more than a thousand years, Albanians and Slavs had been in ceaseless conflict in this area. They had quarrelled over everything - over land, over boundaries, over pastures and watering holes, and it would have been entirely unsurprising had they also disputed the ownership of local rainbows. And as if that were not enough, they were also squabbling over the ancient epics which existed, just to make things completely intractable, in both languages, Albanian and Serbo-Croation. Each of the two peoples asserted that it had created the epic, leaving the other nation the choice of being considered either a thief or a mere imitator. (75) 
And pretty soon, they became aware of the key issue of the quarrel between the two neighboring nations over the epic:

What we are trying to prove is that the material from which Albanian epic poetry is made is Homeric in origin; that would not be possible if the Albanians had not been here since classical times; and what arouses the jealousy and anger of the Serbs is precisely the question of historical precedence in the occupation of the Balkan peninsula. (75)

The Serbs just can't accept that the Albanians were here before they were. Throughout the Balkans, local nationalisms like this give rise to ridiculous and morbid passions, but since this one relates to the Kosovo question, it also has a concrete political implication. (76)

As Homeric scholars, the Irishmen were most interested in everything that could be linked to the ancient Greek epic poetry. They were very much impressed by their meeting with the "intelligent, crafty, and witty" Albanian ambassador to the U.S. when they were applying for visa. ${ }^{1}$

Did you know that some people claim that in the first line of the Iliard, Mênin aeidé, thea, Pêlêiadéô Achilêos ... ("Sing, goddess, of the anger of Achilleus, son of Peleus ..."), the word mênin, as you can see for yourselves, is the Albanian word meni, meaning "resentment". Which means that of the first three or four words of world literature, the first and unfotunately the bitterest is in Albanian ... (50)

When they first encountered with the highlanders from the true epic zone, Bjeshkët e Nemuna (The Accursed Mountains) as it is called in Albanian, they were depicted as speechless.

Their dress was identical to the descriptions they had read in ancient epic poetry, and they almost shouted with astonishment: how is it that they have not changed a thing in a thousand years? Their black cloaks had shoulder-pads decorated with truncated or atrophied winglets that made you shiver. Looking on these highlanders, you were looking at the boundary between men and

\footnotetext{
${ }^{1}$ Faik Konica (1875-1942), one of the great Albanian political activists and writers, was in the 1930s serving as the Albanian ambassador to the U.S., from 1926 until 1939. His most famous prose is Albania: The Rock Garden of Southeast Europe And Other Essays (1957). Originally a Bektashi Muslim, Konica converted to Catholic and was named Dominic, which he never denied. He was the founder of the bilingual journal Albania (in French and Albanian) and played an important role in spreading the awareness of Albanian culture across Europe and in the U.S.
} 
gods, the watershed, the point of contact of of separation, however you wanted to see it. Epic poetry spoke of them, there was even an old Albanian word to describe them, hyanjeriu, or "god-man", presumably without equivalent in any language except ancient Greek [...] The Irishmen thought they could see something Illyrian about the highlanders' dress, as well as a touch of Balkan gloom [...] (73-74)

All the above mentioned, plus many other details, such as the description of the Baffalo Inn as "the oldest house of its kind and has been in uninterrupted existence since the Middle Ages, with the exception of the Inn of the Two Robberts, in Central Albania" (30), serve to show to the world the Albanian nation's antiquity, a treasure possessed by no other nations in the Balkans except for Greece. Serbs, needless to say, were late comers .

According to Bill's imagination, the first Slav incursion into the Balkans took place silently. The Albanians took up their arms only when they realized that their civilization and their existence were in danger due to the pouring of the Slav mass. And Kosovo was the right place where the Albanians held back the Slavs.

Tha Slav tide, it seemed, would never stop [...] more like a natural disaster than a military invasion. That was the shock that disturbed the Balkans most, he reckoned, especially the Albanians of yore. All of a sudden they were in the midst of Slavic sea: a grey, unending, anonymous Eurasian mass that could easily destroy all the treasures of the land where art had flourished more than anywhere else on earth. So what had to happen, happened: the people who had lived here for centuries took up arms and bloodied the shores of the ocean. And the waves were held back at that precise point, the shores of Kosovo. (77)

In fighting against the intruding Serbs, numerous Albanian people lost their life, which led to perpetual enmity between the two nations. The legend of Muji ${ }^{1}$ spoke best for the fact that the Albanians were natives of Kosovo and the reason why Albanians hate Serbs. All of Muji’s seven sons were slaughtered by Serbs and buried

\footnotetext{
${ }^{1}$ Muji is an Albanian legendary figure with super power in the Albanian Epos, which contains mainly the ancient stories about the Albanians fighting against nature and invading enemies, particularly the Slavs. In The File on $H$., the scholars heard different versions of the treachery of Muj's wife Ajkuna after she had been kidnapped by her husband's Slav rival.
} 
on the land where is the now the mountainous area in Kosovo.

For seven hundred years I shall slay thy progeny, Muj had threatened the mother-in-law of his Serbian foe. His own seven sons, all called Omer, had been slaughtered by Rado the Serb and all seven had been buried in the Accursed Mountains, Bjeshkët e Nemuna. (118)

The further their research went on with the Albanian epic, the more they revealed about the connection between the epic and Kosovo. They found out that what became part of the epic were only the most important historical events, among which were the most recent disastrous events in 1878 and 1913. In 1878 the most influential Albanian national revival figures gathered in Kosovo and set up their national goal and platform. But sadly, in 1913, Kosovo was cut off from the main body of the Albanian nation.

The epic awoke from its long slumber in 1913, that was true, but only because a terrible calamity - the dismemberment of the whole country - had prodded it into a final burst of life. (145)

The Irishmen could see no explanation for the epic's thousand-year long lamentation but to interprate it as an Albanian testament which foretold the losing of Kosovo.

Oral recitation was less like a poetic entity than a medieval order whose members, the rhapsodes, had converted singing into a ritual and spread it far and wide, as if they had been propagating a gospel or a liturgy. A national testament could only have been thus: for the epic corpus that foretold and lamented in advance the nation's division into two parts obviously constituted the First Commandment of the Albanian people. That was how you could account for this thousand-year long lamentation, this monotonous wail of foreboding made of the unending repetition of an archaic order. (117-118)

Consequently, though the Irishmen did not want to get involved into the conflict between the two enemy nations, they had to admit honestly what they thought about the Serb-Albanian dispute over the epic.

It would be childish to imagine that each of these nations invented epic poetry independently. One of them must be the originator and the other the borrower. We are personally conviced that as 
they are the most ancient inhabitants of the peninsula, that Albanians must have been the originators of oral epic. (The fact that their versions are much closer to Homeric models tends to confirm this view.) (102)

On the other hand, the well-designed appearance of the Serbian monk shows how Serbia attempted to cover up the truth. What the Serbian monk said to irritate the Albanian hermit proved Serbia's knowledge of the epic's value.

With this machine these Irishmen will cut limbs from your body. They'll mow down all those old songs that are the joy of life, and without them it will be like being deaf. [...] Generation upon generation of your descendants will curse you for having been so careless. (129)

Toward the end of the novel, the Irish scholars saw the report of their story in the newspaper, where Serbia was denounced for crimes committed in order to stop being viewed by the international community as the colonial ruler in Kosovo.

This is not the first time that Slav chauvinists have brutally attacked scholars working on Albania's classical roots. Any mention of the Illyrian origins of the Albanians, in particular, arouses in them a barbaric and murderous jealousy, which is, alas, just as widespread here, in the Balkans. Anyone who deals directly or inderectly with this topic is in their eyes an enemy. And the hand that wielded the crowbar that struck down the Yugoslav scholar Milan Sufflay in a Zagreb back street some ten years ago did not tremble at the prospect of slaying two Homeric researchers from across the Atlantic. (166-167)

To sum up, the lamentation of Albania's partition in 1913 which placed Kosovo and half of the Albanian population under Serbia's rule can be observed clearly in most of Kadare's major works written between late 1970s and early 1980s. If the Kosovo problem is only touched upon or presented with allusion in the works such as The Three-Arched Bridge, The Broken April, The Palace of Dreams, and The Dark Year, then The File on $H$. is dedicated specifically to this historical tragedy of the Albanian nation. The two Irishmen, whose nation is also divided, should have been 
chosen purposefully by the author. ${ }^{1}$ Through what they heard, saw, thought and experienced in their epic research, Kadare contends that Albanians are the native people who have inhabited ever since the ancient time in their territories, including Kosovo. The central task of the novel is to present Serbia as the as the colonial ruler over Kosovo. Though the foreign scholars eventually failed to collect the research materials which would do the Albanian nation a big favor in claiming for soverignty over Kosovo, the novel nevertheless conveys successfully the political message that Serbia not only illegitimately occupied Kosovo, but also committed all sorts of evil deeds and crimes in an attempt to present itself as the legitimate owner of Kosovo.

\subsection{The Criminal Other}

There are two different results with regard to the effect of colonial rule. Some scholars credit the colonial rule with development. Hong Kong is often taken as an example of having benefitted greatly from the British colonial rule for its modernization. ${ }^{2}$ On the other hand, numerous researches have been published, such as Colonialism-Lumpenization-Revolution, revealing the devastating result of colonial rule. $^{3}$

As said previously, Kosovo Albanians regarded Serbia as the colonialist Other. This anti-colonialism sentiment was strengthened due to their perception of being second-class citizen and being exploited economically. Indeed, most of Kosovo's minerals and electricity went to Serbia as a free "gift". As a result, Kosovo remained

\footnotetext{
${ }^{1}$ Max did not address himself to colonial people, the only exception being Ireland. Online source: Marx and Engels on Ireland. http://www.marxists.org/archive/marx/works/1867/12/16.htm, accessed on Feb. 15, 2013.

${ }^{2}$ Hong Kong enjoyed a continuous growth for a period of five decades following World War II. In 1945, Hong Kong's per capita GDP was lower than that of India and Kenya. However, by 1992, its per capita GDP had overtaken that of the UK. Refer to: James Bartholomew, The Welfare State We're In. London: Politico's Publishing Ltd., 2004, p.317.

${ }^{3}$ Rajendra Prasad, Colonialism-Lumpenization-Revolution, Vol. 1, Cacutta-Shanghai, 1850-1914. Delhi: Ajanta Books International, 1995. In contrast to those who credit British rule with development, Prasad claims that Britain was responsible for crimes against the innocent colonial world of humanity.
} 
the most underdeveloped region in the communist Yugoslavia. In other words, contrary to the cases like Hong Kong where the colonial rule was in general positively viewed by the local people, Kosovo suffered from backwardness and lack of development under the Serbian colonial rule. Nora Beloff, the British historian pointed this out in her book Tito's Flawed Legacy:

The average income of individual residents of Kosovo compared with that throughout Yugoslavia slumped between 1947 and 1962, from $52.4 \%$ to only $34 \%$. In 1980 , after more than a decade of Federal funding, it had still risen to only $40 \%$. (211)

Therefore, the Kosovo Albanians never ceased fighting for their national aspiration. Commenting on Kosovo's colonial status, the most prominent Kosovo Albanian intellectual Rexhep Qosja underlined "there is one thing which has proven stronger than any weapon: the will of nations for freedom and independence". He declared that Serbia as a hated colonialist Other is destined to doom (Qosja 1997: 207-232). Serbia, naturally, would not tolerate Kosovo Albanians' struggle for independence. In suppressing Kosovo Albanians' resistance and protest activities, Serbia committed atrocities and became the criminal Other of the Albanian nation.

Kadare did not fail to portray Serbia as the criminal Other against Kosovo Albanians. Immediately after the 1981 demonstrations demanding for Kosovo's republic status were suppressed by the Serbian police forces, Kadare wrote the novel The Wedding Procession Turned into Ice, in which Serbia is denounced as a horrible state terrorism criminal. By this novel, the author aimed at two things: first, to intensify the conflict between the Kosovo Albanians and Serbia; second, to gain sympathy and support from the international community.

The protagonist of the novel is woman doctor named Teuta Shkreli, director of the surgery department of a Prishtina hospital, whose life was threatened due to her

\footnotetext{
${ }^{1}$ Nora Beloff, Tito's Flawed Legacy: Yugoslavia \& the West Since 1939. Boulder: Westview Press, 1985.
} 
solidarity with the demonstrators. After the demonstrations broke out, ethnicity became the most important indicator of one's political identity. Ethnic hostility camouflaged during Tito's time eventually came to the fore. This was even more apparent in the hospital, where ethnic Albanian doctors were suspected of having offered help to the wounded demonstrators. Teuta and her colleagues were disturbed by endless meetings and inquiries. They were interrogated again and again why ambulances and additional beds had been arranged in advance for demonstrators and why the hospital register containing the names of patients treated on the demonstration day had disappeared. Obviously the Serbian authority wanted to find out who in the hospital had secret contacts with a conspiratorial group and received orders from them. Mute against the questions, they were also accused of defending each other on the ethnic basis. Serbian secret service employees could be at every corner of the hospital. Everybody, particularly the suspected intellectuals like Teuta, was put under surveillance and high psychological pressure. Teuta had to watch out and keep vigilant every minute. She found herself highly alert to the presence of her Serbian colleagues when she was performing a prostate operation on a Serb patient, because rumor already had it that Albanian doctors were mutilating Serb patients. After the massacre of the demonstrators and the subsequent repressive measures of the Serbian government against Albanians, suspicion and hostility had made it extremely hard if not impossible even for doctors of the two ethnic backgrounds to cooperate in a medical operation.

Teuta's husband, Martin Shkreli, is a university professor who has always held the view that forgiveness is a virtue of civilized society and has argued for the possibility of harmonic relations between the Albanians and Serbs. He had hoped, after Rankovic was ousted, that brotherhood could function. However, the cruel 
reality, especially the fact that his favorite student, the one who was in love with a Serbian girl, had been killed by the Serbian army, made him realize that he had been too naïve and optimistic in believing in peaceful coexistence of the two ethnic groups in one family. Looking at the bookshelves of his library where dozens of books on genocide and massacres were lying, including the doctrine of the Yugoslav academician Čubrilović on the extermination of the Albanians, the old Albanian frontier epics, the Slav epics ..., Martin finally understood that Serbs and Albanians would never be able to live together.

The plot of the novel is simple. Doctor Teuta travelled only from the hospital to her home, where she had conversations with her husband about the severe situation. She is depicted as intelligent, brave, and conscientious. She knows what to do and to say in difficult situations to protect her people and herself. Apart from Teuta and her husband, there are also the Serbian government officials who presided over the interrogation meetings, as well as three retired Serbian secret agents, who willingly accepted the government's request to help out in repressing the Albanians. The central task of the novel, i.e. the construction of Serbia as the criminal Other to the Albanian nation is completed through these figures.

First, the moment Teuta appears in the novel, walking on the way from home to the hospital, we are informed of the crimes committed by the Serbian army.

The curb of the sidewalk on the right side of the street leading to the hospital had been smashed by tanks and had not yet been repaired. This was the first spot where the armored police vehicles had first plowed into the crowd of demonstrators. You should still see the tracks on the asphalt. (106)

Being the surgeon who treated the wounded demonstrators, Teuta's memory reveals the horrible crimes unimaginable in the modern world.

Every operation now reminded her of the ones she had carried out on "that day". She would never forget them as long as she lived. 
The patients were dripping blood before she had even set the scapel to them. It was all horrible, like living in another age. Only the surgical instruments looked modern. The wounds of the demonstrators seemed right out of the Middle Ages: bodies mutilated by tanks, appalling wounds. (108)

About half of the novel describes the denunciation meetings and Teuta's reflections on the meetings. Each time Teuta was questioned whether she was consciously giving treatment to the demonstrators. Her answer unmasked in an ironic way the false story told by the government and exposed Serbia's atrocities against the demonstrators.

Comrade Kostić, you are speaking here in front of hundres of individuals about a multitude of people killed and wounded, about torrents of blood and hails of bullets. Do you not think that in so doing you are spreading anti-Yugoslav propaganda? The official communique stated that only nine people died and a few dozen were wounded. you would have us think that in our hospital alone, which is one of dozens of hospitals in the province, masses of demonstrators had been treated. You would have us believe that a real bloodbath took place. I would advise you to consider carefully what you are saying. (119)

Teuta insisted at the meetings that she was not aware that the wounded patients were demonstrators, but in fact she knew clearly what had happened. More than that, the bullets and the bloody patients took her mind back to the Serbian atrocities when she was still a child. By relating the savage repression of 1981 demonstrations with Alexander Ranković's time, Kadare tells the readers that it was not the first time that Serbia was committing horrible crimes.

She realized that the wounded had been transported straight from the scene of the massacre and every time she clanked an extracted bullet into the mental bowl, a shiver went up her spine. She heard the voices of the old women she had known as a child, relating in the solemn tone appropriate to such tragic events, "Then they shot Azem. They got him in the lower ribs ..." (144-5) ${ }^{1}$

What the retired Serbian secret service officers said further proved Serbia's prior

\footnotetext{
${ }^{1}$ The Azem mentioned in this paragraph refers to Azem Galica (1889-1924), one of the famous leaders of Albanian armed resistance to Serbian occupation and rule. He fought for the unification of Kosovo with Albania ever since 1912 and is considered Albanian national hero.
} 
criminal records, not only under Ranković but also under Karađorđević ${ }^{1}$. They complained about being forced out and treated with disdain for so long, and now they were happy and impatient for the rebellion to be put down ruthlessly. Not only that, they even wished to annihilate the whole Albanian race.

They've forgotten us. They don't need us anymore. When there was work to be done that meant getting your hands bloody up to the elbows we were the first ones they would call, but now they've come up with new slogans: unity and faternity among the peoples, human rights and other such nonsense. (121)

"Don't listen to those Croatian and Slovenian sissies whose blood has been luke-warm for centuries", they would say. "Let's beat the Albanians to a pulp the way we used to ... in the good old days." (124)

Let them give us back the freedom we had under Karadjordjevic to wipe them off the face of the earth, with their language, their damned alphabet that they claim is older than ours. (127-128)

The reappearance of the retired secret agents caused both disgust and fear in Teuta. She knew that behind them was the repressive state apparatus and she was under their special surveilance. Indeed, people like Teuta had their specific files in the Interior Ministry and they might be persecuted at any time. When the news came that the files would be reopened, one of the retired informers while closing the palm of his hand, "We'll get that doctor of yours now! Clack, like a mouse in a trap" (126). By describing the excitement of the former secrets agents, Kadare shows that apart from tanks and machine guns, Serbia's state terror also consists in establishing political files for individuals and the subsequent persecutions.

All one hundred thirty-eight thousand files will be reopened. The reopening of the files had been one of his wildest dreams, always accompanied by an uneasy nostalgia. He had seen them in his sleep many times, in white rows, thousands of them, like cold tombstones, each with a name on it that was no longer of any use because the bodies had dsappeared. (126)

\footnotetext{
${ }^{1}$ The former royal family of Serbia and Yugoslavia, which committed numerous crimes against the Albanians in the territory expansion during and after the Balkan Wars.
} 
Dobrila's mind was becoming foggier and foggier. They talked about this and that, but the subject of the conversation always returned to the files. Empy tombs there might be, but they would soon fill up again. Those who had pried open the tombstones and escaped from their tombs would return. One by one they would climb back in and lie down stiffly in rows, thousands of them, waiting. (127)

Ross defines the "state" as "the elected and appointed officials and the bureaucracy" (1). ${ }^{1}$ He points out that, within its territorial borders, a state may engage in state terror and terrorism, torture, war crimes, and genocide, sometimes not as the direct criminal actor, e.g. through the agency of bodies such as the police, but more usually, as directly involved in excessive secrecy and cover-ups, disinformation, etc. (5). ${ }^{2}$ In The Wedding Procession Turned into Ice, the author presents Serbia as engaged in state terror while using all possible ways in its control.

"The whole machinery has been put into motion," she [Teuta] said. "I didn't even know that Yugoslavia had so many party, government and state organizations, so many different socialist councils and communist leagues. God only knows how many provincial, inter-provincial and federal committees and assemblies there are. (162)

In order to cover up their crimes, the Serbian government used its official media to misinform the public with a hostile tone against the Albanians, implying a preconceived anti-Yugoslav plan for the demonstration. It went even so far as to bomb its own embassy in Tirana to draw the international attention and to make Albania responsible for turmoil. The moment she heard the news about the bomb, Teuta understood that it was Serbia's complot, which was later confirmed by the Albanian official statement.

Last night Tanjug ${ }^{3}$, today the bomb. Someone could not stand to live without poisoning their existence. And what if ... (she tried to

\footnotetext{
${ }^{1}$ Jeffrey Ian Ross (ed.). Varieties of State Crime and Its Control. Monsey, NJ: Criminal Justice Press, 2000.

${ }^{2}$ Jeffrey Ian Ross (ed.). Controlling State Crime, 2nd edition, New Brunswick, NJ: Transaction Publishers, 2000.

${ }^{3}$ Tanjug, short for Telegrafska agencija nove Jugoslavije (Telegraphic Agency of New Yugoslavia), was the leading newspaper in the former Yugoslavia. It is now the main newspaper in Serbia.
} 
repress the thought, butit was to late), what if there were dark forces at work in Tirana too, spreading poison. She refused to believe it, and yet, it was there that the bomb had been thrown. (180)

The Albanian government declared that the explosion on the balcony of the kitchen of the Yugoslav Embassy in Tirana was caused by the Yugoslavs themselves with the sole aim of exacerbating relations between the two countries and justifying their reign of terror in Kosovo. (184)

According to Martin Shkreli, the international community would have no difficulty to stand on the Albanian side because Serbia's crime took place right in the modern Europe, against people demanding for something deemed as noble ever since the ancient time.

It's barbaric, and worse. A demonstration takes place with people demanding ... what are they demanding after all? Something that has been held in esteem for two thousand years, ever since the time of Caesar and Brutus, a noble aim, a "republic". And at the end of the twentieth century right in the middle of Europe they send in tanks against these people. Under the circumstances it shouldn't be difficult to choose sides. (160-1)

Serbia's crime was also recorded in a cassette where the delirious ravings and groans of a dying patient, Martin's student Shpend Brezftohti, would serve as historical evidence:

They're shooting from behind. Watch out! They're shooting from the window, damn them! The whole Nish Army Corps is on the attack. Watch out, they are shooting from the windows. God help us if the tanks show up...

But for Kadare, all these accusations and denunciations of Serbia's crime from the Albanian side is not convincing enough. Mark Rogova, the one who always debated against Martin's idealist dream about Serbian-Albanian relations, shouted to Martin while quoting his Serbian colleague's words:

We have baptised the word "republic" in blood. What other country on earth has produced so many Brutuses in this century? Thousands of them. What do you have say now?

Look what a Serbian colleague of mine wrote: 'I am ashamed, 
ashamed of what has happened. This shame I share with all those who lay claim to the true Serbian culture, in the name of which I fall to my knees and beg forgiveness of you, my colleague, my brother, my fellow human being.' That's what he wrote. And I couldn't care less. No forgiveness will bring the dead back to life. Or do you still believe in such nonsense?" (166)

Finally, rumors were also employed as a way to prove what a criminal Other Serbia is to the Albanian nation. In the Balkan mentality, female body often personifies the nation, especially in armed conflicts. "Women became symbols and property of the national community, markers of national identity. Their violation was reterritorialized by becoming primarily an act of ethnic violence instead of an expression of gender power relations." (Sofos 82) ${ }^{1}$

There were rumors that Albanian female students taken into custody by the police during the demonstrations had been sterilized. All of Kosovo had quivered at the thought. No one could believe that that symbolic crime of former days had been revived. To counter the rumors, the other side had alleged that it was Albanian doctors, and not the Serbian police, who had brought back that quintessential act of warfare between the races. (109)

After the demonstration, an order was issued requiring the front doors to be left unlocked at night. This rule, which was not enforced even in curfuew during the Nazi occupation, indicated that Albanians were under the highest scale of terror. Is it only for the convenience of check and control? The Serbian secret agent's description that the door unlocked "was like women with nothing on under their skirts" reveals implication of such a rule based on the logic of "woman as symbol of nation": the Albanians were totally defenseless under Serbian state terror even after the bloody massacre.

In one word, what Kadare presents to his nation and the world in the novel The Wedding Procession Turned into Ice is a horrible anti-Albanian criminal Serbia. The wedding between the two nations is impossible due to the crimes committed by Serbia

\footnotetext{
1 Sofos S. "Inter-ethnic Violence and Gendered Constructions of Ethnicity in former Yugoslavia", Social Identities, 2: 1 (1996), pp. 73-92.
} 
against the Albanian nation. The same image can be found at the end of the twentieth century in Kadare's another work in the diary form, Ra ky mort e u pamë (Death Befell and and We Saw Each Other). What was happening in Kosovo in 1999 was drawing the attention of the whole world. Kadare published this collection of diaries (Jan. - Oct. 1999), critical essays published in 1999 in Western newspapers with regard to Kosovo War and letters to Western presidents in 1991 (to U.S. President Bush, French President Mitterrand and Czechoslovakian President Havel) in order to show his political stand and gain support from the international community. It is mainly about the atrocities committed by Serbian army to Albanians and the international reactions to the tragedies. Arguing against the scholars who opposed NATO's bombing of Serbia, Kadare asked:

"Mr. professors, the lands of Kosovo are full of bodies of babies who have been killed by the sovereign country, what can you say about this?" (Kadare, 2000: 159)

The title of the book suggests that it was not until the brutal mass murder of the Kosovo Albanians happened that the international community decided to liberate the Kosovo Albanians from Serbia's criminal rule.

\subsection{The Irreconcilable Other}

In the last decade of the twentieth century, the world was shocked by the bloody ethnic conflicts, such as those in the former Yugoslavia, Rwanda, etc. which killed numerous innocent civilians. The violence was generally explained in the primordialist approach as a tragedy due to the incompatible ethnicity and the rivalry between ethnic groups. Despite much academic criticism of Primordialism, and the development of other ethnic theories such as constructivism and instrumentalism, Primordialism is "influential in identifying the enduring strength of ethnic ties and its 
member's commitment to it" (Joireman 20) ${ }^{1}$. Asserting that "the urge to define and reject the other goes back to our remotest human ancestors, and indeed beyond them to our animal predecessors, $" 2$ the primordialist approach tends to attribute inter-ethnic violence solely to the identity incompatibility between the groups ever since the ancient time. In other words, the primordialist view emphasizes the irreconcilable cultural differences and accumulated historical hatreds are the major cause of ethnic conflicts.

Employing the primordialist approach in treating the Kosovo problem, Kadare wrote ad hoc the novella Elegy for Kosovo, where he invokes solely the ancient hostility between the two nations with primordial origins to explain the irreconcilability of the Serbo-Albanian ethnic conflict. Written between March 1997 and March 1998, the time when the Kosovo Liberation Army (KLA) was still regarded by the West as a terrorist force, the author purposefully evaded the question of who should be held responsible for the escalation of the armed conflict in Kosovo, the KLA or the Serbian army. However by mythicizing the primordial hatred and focusing on the impossibility of reconciliation between the two nations, Kadare was in fact telling the world that it would be futile to try to keep the two nations together under one roof, i.e. within Serbia.

Elegy for Kosovo takes us back to the Kosovo Field War against the Ottoman invasion in 1389. The novella comprises three parts: the Ancient Battle, the Great Lady, and the Royal Prayer. Before going to describe the historical battle itself, the author takes time to present the readers with the situation in the Balkans prior to the historical battle. In March 1389, three months before the battle, rumors were

\footnotetext{
${ }^{1}$ Sandra F. Joireman, 'Primordialism', in Nationalism and Political Identity, Cornwall: MPG Books Ltd, 2003, pp. 19-35.

2 Cited in Bernard Lewis, "Muslims, Christians, and Jews: The Dream of Coexistence," New York Review of Books, 26 March 1992, p. 48.
} 
whispered that the Turkish were going to launch a war to conquest the Balkans. It was said that the Turks had moved their capital from Bursa to Adrianople in order to shift their empire to Europe. The local forces were divided: some had declared vassalage or established secret bondage to the Turk, whereas others were determined to protect the cross of Christianity. Albanian princes participated in anti-Ottoman wars. Before 1389, the Albanian Count Muzaka rushed off to help the Serbs against the Ottoman invasion and fell. In 1389, two other Albanian princes, Counts Gjergj Balsha and Demetër Jonima, together with Bosnians, Rumanians, Hungarians, Croatians, etc. allied with the Serb Prince Lazar to resist the Ottomans. This historical fact is emphasized many times in the novella as a response to the Serbian nationalist propaganda that Serbs alone fought in the Kosovo Field War.

Special attention was given to the enigma of the Turkish Sultan Murad's death at the battle. There were different versions of how the Sultan was murdered. While the possibility of being assassinated by a Balkan soldier was logically excluded, the novella suggests that the Sultan was killed by his own people as a result of conspiracy. The Sultan's elder son was also killed to clear the way so that the younger son who was ambitious to conquest the whole Europe could ascend legitimately to the Ottoman throne as the only heir. After his death, the Sultan's blood and intestines were buried in Kosovo. It is suggested that by pouring the monarch's blood on the Plains of Kosovo the Turks gave a meaning of eternal possession of the Balkans and a direction of their future invasion program toward Europe.

The first two elegies describe the day of the battle, and what happens to the two protagonists, the Albanian minstrel Gjorg and the Serb minstrel Vladan on their fugitive way afterwards. For the medieval Balkans, minstrels were important entertainers during war time. Their role was to sing epic songs and the glory of their 
nations to boost morale of the army. Preparing for the imminent war, the minstrels composed songs, each in his own language, but ridiculously, the songs eventually turned out to be almost the same as the ancient hate songs sung by the Serbs and Albanians for centuries against each other with regards to their fight over Kosovo. When these songs were performed on the eve of the battle, the Balkan princes just laughed out loud, a sign of understanding that primordial ethnic hatred would not disappear because of temporary alliance, in other words "blood flows one way in life and another way in song" (20). A combination of memory and myth construction constitutes the social contract between the Serbs and Albanians in the form of epic song repetition.

When the banners of the Balkan allied army fell one after another, Gjorg and Vladan ran away from the battlefield and together with other fugitives they finally headed north seeking a safe place to settle down. Separated for a while due to the commotion of the battle, they were happy to see each other again and even became kind of friends. Nevertheless, whenever they opened their mouths to sing, they couldn't help singing animosity between their Albanians and Serbs. This is what happened when they arrived at a German or French principality and were invited to sing for the banquet held by the lord of the castle. The nobles at the banquet got very angry when they heard songs. They simply couldn't imagine how the Balkan lands had fallen and the minstrels continued singing hostile songs against each other. However, there was a venerable lady among the guests, who instead of denouncing the minstrels in contempt asked them to sing other songs or tell their local tales. The great lady, possibly the most erudite lady of all the French and German lands, knew the value of the Balkan tales, which she regarded as "of the same diamond dust, the same seed" (70) with the Greek tragedies. She had written countless letters to princes, 
cardinals, even to the Pope calling for their attention to the Balkan tragedies, which would make the world twice as beautiful if they had been preserved properly. The great lady treated kindly the minstrels because they came from "forecourt of Europe", the "bridal chamber" of Europe. She was grateful to the Balkan people for resisting the Ottoman invasion and meanwhile very concerned about the future of Europe. Sadly, the old lady died the day after the banquet. The minstrels, whom she encouraged to sing the Balkan tales instead of the hate songs, sang with numbness their eternal songs for her at her funeral: "A black fog has descended, the great lady had died. Rise, O Serbs, the Albanians are seizing Kosovo!” - "A black fog has descended upon us, the great lady has died. Rise, O Albanians, Kosovo is falling to the pernicious Serb!”(79)

The last part of the novella is a monologue of the spirit of the Sultan whose blood and entrails have been buried on the battlefield. At the beginning, in his solitude, he cursed the Balkan people for charging him to set out on military expedition in his old age and laying down his life on the Kosovo Plains. But gradually he felt no more joy at hearing the Albanians and Serbs slaughtering each other. He felt tired of witnessing the ceaseless inter-ethnic fighting for six hundred years. Doubting that his blood might be the origin of all the horror, he prayed to Allah that his blood be removed from Kosovo.

The leitmotif in this novella is similar to what Robert Kaplan calls the "Balkan Ghosts". In his book Balkan Ghosts, Kaplan contended that the conflicts in the Balkans were based on ancient hatreds beyond any outside control. This idea was shown at the very beginning of the novella, when the author describes the Balkan people's perception of the imminent Ottoman invasion.

This feeling of constriction was spawned more from the ancient memories of the people than by their lands and languages rubbing 
against each other. (3-4)

The Balkan conflict was to such an extent that even the reason for the removal of the Ottoman capital from Bursa to Adrianople was, as suggested by some people, to keep an eye on the quarrels of the peninsula's princes. The reason why others objected this suggestion makes the ancient Balkan inter-ethnic conflict more impressive to the reader:

Our wrangling is so deafening that there is no need to come closer - in fact you can hear it better from afar! (7)

Therefore, as carriers of their ethnic history and culture, the minstrels always appear while singing songs reflecting their ancient conflicts. This is particularly true when Serbs and Albanians are involved.

The Serbian elders chanted: "Oh, the Albanians are preparing to attack!" and the Albanian lahuta minstrels sang: "Men, to arms! The pernicious Serb is upon us!" (16)

Confronting mockery why they were singing the same old songs even when they were allied to fight together against the imminent Turkish invasion, they explained:

But it is where we've always turned to find parts for our songs, and this is where we will always turn. These parts are not like those of weapons that change every ten years. Our models need at least a century to adapt! (16)

If it is incomprehensible for outsiders why the minstrels sang their ancient hate songs even the night before the battle against their common enemy, the Serbs and Albanians would just take it easy, not only because they knew it was the minstrels' job to sing history instead of reality, but more importantly, they were aware that no matter what the result would be at the end of the battle, the Serbs and Albanians would continue to fight over the right of possessing Kosovo.

All the while the minstrels sang their ancient songs without changing anything, as was their custom. The Serb Prince, Lazar, and the Albanian Count, Gjerg Balsha, laughed out loud when they heard the Serbian gusla player - "Rise, O Serbs! The 
Albanians are taking Kosovo from us!" - and the Albanian lahuta player - "Albanians, to arms! The pernicious Serb is seizing Kosovo!" (20)

Indeed, the Serbs and Albanians resumed their fighting each other only forty years after the Kosovo Battle. The irreconcilability of their ancient and protracted conflict is further proved by the underground Sultan's anger and sigh.

Even without my curse they were determined to trample one another into the ground. They had set out on this course of destruction six hundred, seven hundred years before my campaign. They had reached a temporary truce in these flatlands, only to resume their terrible slaughters even more viciously than before.

The Balkans, instead of trying to build something together, attacked each other again like beasts freed from their iron chains. Their songs were as wild as their weapons. And the prophecies and proclamations were terrible. "For seven hundred years I shall burn your towers! You dogs! For seven hundred years I shall cut you down!" the minstrels sang. And what they declared in their songs was inevitably done, and what was done was then added to their songs, as poison is added to poison. (86)

In the novel, Vladan and Gjorg epitomize respectively the Serb nation and the Albanian nation, whereas their musical instruments, gusla and lahuta, represent their respective cultures. The bizarre companionship between Vladan and Gjorg toward Western Europe can be viewed as alluding to the common orientation of Serbia and Albania toward Europe. Traveling on the way to Europe, they had sensible reflections on their defeat, which unfortunately turned out to be helpless for their reconciliation.

They now realized that, divided as they had always been, they had never given their peninsula a name. Some had called it "Illyricum", some "new Byzantium", others had opted for "Alpania", because of the peninsula's alps, or "Great Slavonia" because of the Slavs, and so on. Now it was too late to do anything, and so, without a common name, but with a name bestowed upon them by the enemy, they marched to battle and defeat. (17)

For hundreds of years the evil persisted, [...] Serbian and Albanian songs said the exact opposite from each other ... particularly when it came to Kosovo, as each side claimed 
Kosovo was theirs. And each side cursed the other. And this lasted right up to the eve of the battle. [...] And all the while, across the plain, the Turks were gathering to destroy them both the following day! [...] We ourselves have brought this disaster upon our heads, my brother! We have been fighting and slaughtering each other for so many years over Kosovo, and now Kosovo has fallen to others. (49)

Vladan lost his gusla on the battlefield. His interest in playing lahuta was a good opportunity for cultural communication, but nevertheless it failed to stop him from singing against Albanians.

He held it [the lahuta] in his hands for a few moments, then his fingers timidly stretched to pluck the single string. [...] Gjorg saw Vladan's face turn spectral white. And the words, heavy as ancient headstones, were filled with sorrow. "Serbs, to arms! The Albanians are taking Kosovo from us!" (51)

All these show that they were locked in a deadly embrace with each other. In other words, "both men were prisoners, tied to each other by ancient chains, which they could not and did not want to break (51)".

So they repeatedly sang the hate songs, on their way to Europe between themselves, at the banquet of a Western European castle, at the Great Lady's funeral, etc. Even though they were grateful to the Great Lady, they could not sing other things at her request. The reason for that is:

They could not break out of the mould. Besides which, they would first have to consult their elders. Consult the dead. They would have to wait for them to appear in their dreams so that they could consult them. (73)

In other words, as pointed out by S. A. Giannakos, "Sacrifice by individuals in the past command respect and reverence and obligates individuals of the present generation to preserve a degree of security for future generations. [...] (often this sense of obligation is metaphorically referred to as collective memory or common 
historical experience)" (12). ${ }^{1}$ As martial minstrels, Vladan and Gjorg were filled with fervor and hatred, and they were obliged to show due respect to the dead, because "everything linked with blood is eternal, imperishable, and guarded by fate. (31)"

Naturally, the Balkan endless hostility and blood revenge culture would bring nothing else but a negative image of the Balkans to the modern Western Europeans. The words that the banquet guests expressed their intense antipathy and loathing would just lead our mind to the Balkanist discourse in the last two decades, in which the Balkans are viewed as backward, primitive, tribal and aggressive, in short, as the Other within Europe.

"It is true that there is dissention everywhere, but dissention like yours is really unique in the world!" one of the guests said contemptuously. (68)

"What songs do you expect from them?" one of the guests at the end of the table asked. "Hate is all they know!" (69)

"They corrupt everything, the way they corrupt the milk," a guest shouted through the mocking laughter. (69)

These remarks can be used to support what Kaplan asserts in his Balkan Ghosts regarding the Balkan ethnic hatred.

Nazism, for instance, can claim Balkan origins. Among the flophouses of Vienna, a breeding ground of ethnic resentments close to the southern Slavic world, Hitler learned how to hate so infectiously. (iii) ${ }^{2}$

Whereas Larry Wolff and Maria Todorova claim that the pejorative Balkanism is a politically invented Other in contrast to the rational and civilized Self of Western Europe $^{3}$, Kadare seems to justify in this novella the Western attitude toward the Balkans. He even uses the Sultan's suspicion and his desperate prayer to emphasize

\footnotetext{
${ }^{1}$ S.A. Giannakos, "Introduction" in S.A. Giannakos (ed) Ethnic Conflict: Religion, Identity, and Politics. Athens, OH: Ohio University Press, 2002.

${ }^{2}$ Robert Kaplan, Balkan Ghosts. New York: Vintage Books, 1993.

${ }^{3}$ For Balkanist discourse please see Larry Wolff. Inventing Eastern Europe: The Map of Civilization on the Mind of the Enlightenment. Stanford: Stanford University Press, 1994. and Maria Todorova. Imagining the Balkans. New York: Oxford University Press, 1997.
} 
the incomprehensible hostility between Serbs and Albanians.

During my worst hours I am seized by the suspicion that maybe my blood is the origin of all this horror. I know this is a crazed suspicion, and yet, in this non-existence in which I am, I beg you: Finally grant me oblivion, My Lord! Make them remove my blood from these cold plains. And not just the leaden vessel, but make them dig up the earth around where my tent stood, where drops of my blood spattered the ground. [...] Take away all the mud around here, for even a few drops of blood are enough to hold all the memory of the world. (87)

It is said that President Clinton read Robert Kaplan's book Balkan Ghosts in 1993 and remained convinced that the United States could do nothing to change "history's cauldron in the former Yugoslavia (quoted by P. H. Liotta, 28). ${ }^{1}$ Obviously, with this work, Kadare intended to send the message that there is no use to reconcile the Serbo-Albanian conflict in Kosovo.

The idea of irreconcilability of the Serb-Albanian ethnic conflict appeared also in Kadare's works of early 1980s. For example, in The Wedding Procession Turned into Ice, the author made it clear that the two nations would never be able to get out of the cycle of mutual hatred.

In the Gadimja Cave a stalactite and a stalagmite were growing towards one another along a single axis. Geologists had calculated that it would take one and a half million years for these formations, which the press and television had dubbed the Romeo and Juliet of Kosovo, to meet. Although nothing more specific was said, it was generally understood that the Romeo was Albanian and the Juliet Serbian and the time span of one and a half million years was proof of how unlikely it was that the hostility between the two peoples would disappear in the foreseeable future. (135-6)

In the novel The File on H., when the Irishmen asked the owner of the inn about the Serbo-Albanian enmity, the answer is "They are maybe even worse than you think. Do you know what an Albanian poet wrote? We were born to mutual anger..." (78,

\footnotetext{
${ }^{1}$ Elizabeth Drew, On the Edge: The Clinton Presidency. New York: Simon \& Schuster, 1994. p. 157, quoted in P. H. Liotta, Dismembering the State: The Death of Yugoslavia and Why It Matters, Lanham of Maryland: Lexington Books, 2001.
} 
italic emphasis mine). ${ }^{1}$ Also in the novel, the ever-lasting quarrels and conflicts between Albanians and Serbs are also shown through the eyes of an American Embassy diplomat who warned the Homeric scholars not to get involved in the quarrels.

The consul had shown them a pile of Albanian and Yugoslav newspapers and, with a smile on his face, translated extracts for them, so as to give them an idea of the style of polemical writing in the Balkans. Once both sides had exhausted the available and imaginable stock of insults, the Serbian press declared that for the greater good of Europe Albania should be wiped off the map of the continent - and the Albanian papers, which presumably though the same of Serbia, brought the argument to a conclusion by stating that no dialogue was possible between two peoples whose names derived, on the one hand, from the word for "snake", and on the other, from the word meaning "eagle". (112)

Then why does Kadare present the Serb-Albanian conflict like that hopeless for reconciliation? Certainly Kadare did not want President Clinton and Europe to set back and leave Kosovo alone. On the contrary, it is stressed, through the Great Lady in Elegy for Kosovo, that the Balkan region should under no circumstances be abandoned.

It is all there, [...] Fragments of the great ruins that gave birth to everything. We must not abandon our outer court! [...] If it falls, we shall all fall! (78)

Here the word "abandon" means no international intervention and Kosovo being left under Serbian rule. Back in 1998, while the armed conflict between the Serbs and Albanians in Kosovo was escalating, the West was still hesitating whether they should intervene. Meanwhile, attempts were made to reconcile the conflict on the basis of acknowledging Serbia's sovereignty over Kosovo. It was in such a political context that Kadare presented, on the one hand, the irreconcilability of the conflict, and on the other hand, the necessity of Western intervention to end the conflict by separating the

\footnotetext{
${ }^{1}$ Ismail Kadare, The File on H. Trans., David Bellos. London: Vintage Books, 2006.
} 
two parties involved. In other words, Kadare's underlying message is that, instead of negotiations with Serbia, the West should separate Kosovo from Serbia. Anyway, it would be an intervention for justice, as in the Albanian minstrel Gjorg's words:

[Q]uarrels were always started by those who came last, that when the Serbs had come down from the north, the Albanians had already been there. (49)

\subsection{Discussion}

Kadare's works can be seen as the barometer of Albanian political change. This is also true when the Albanian national problem, i.e. the Kosovo problem, is concerned. When the Albanian government adjusted its strategy and tactics in solving the Kosovo problem, the first signals were shown in Kadare's works. Put the other way round, as the Albanian national writer, the messages conveyed in Kadare's works can serve as evidence for the analysis of the change of Albanian policy toward Kosovo.

Analyzed above are Kadare's fictions written in 1980s and 1990s in which he treated the Kosovo problem from mainly three aspects: Kosovo as a Serbian colony, Kosovo as a place where Serbia committed atrocities against Albanians, and Kosovo as the origin of Serb-Albanian irreconciliable conflict. These works, which present systematically the neighboring Serbia as an evil, criminal and irrational Other of the Albanian nation, plus the initial signals released toward the end of 1970s in Broken April and Three-Arched Bridge claiming historical sovereignty over Kosovo, indicate Albania's strategic change in its attitude toward Kosovo issue.

According to Kadare, Albanians used the word "serpent" back in the 1930s to refer to the Serb nation as the evil Serbian Other (268). ${ }^{1}$ In his The File on H, Kadare metaphorically described the hostile and non-reconcilable relationship between Serbs

\footnotetext{
${ }^{1}$ Ismail Kadare, Invitation to the Studio (Ftesë në studio). Tirana: Naim Frashëri, 1990.
} 
and Albanians as between "Serpent" and "Eagle" (112). However, Serbia was actually depicted as a serpent much earlier, in a caricature published in an Albanian magazine named Dielli (The Sun) in 1913, where Albania was presented in the form of a lady defending herself from the neighboring countries: her right hand fighting against Montenegro (represented as a monkey), her left hand fighting against Greece (represented as a leopard), while her legs were bound by Serbia (represented as a snake). The text in the caricature reads: Get away from me! Bloodsucking beasts!! (Çporruni prej meje! Egërsira gjakëpirëse!!)

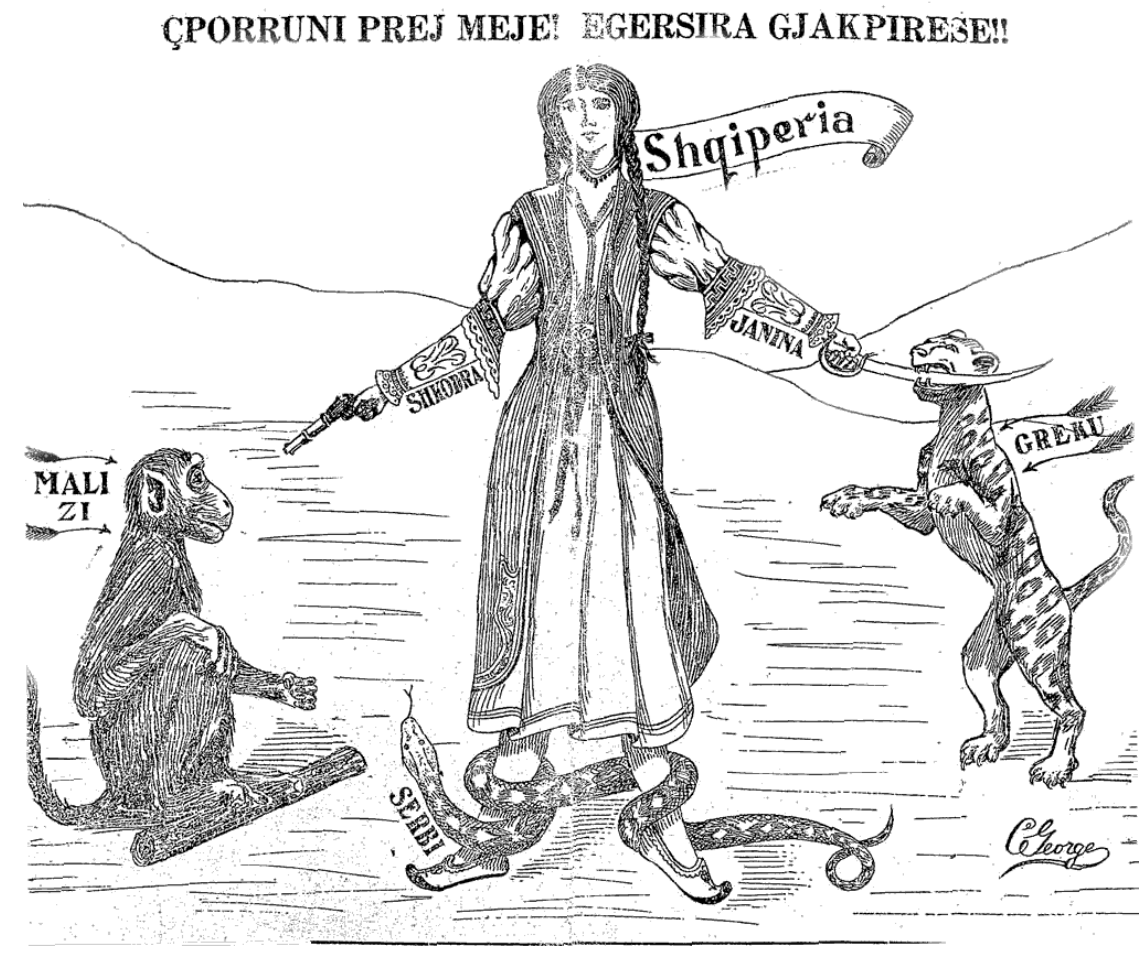

(First published in Albanian newspaper Dielli, February 13, 1913, p. 3) ${ }^{1}$

Serbia was perceived by the Albanians as the biggest potential threat to the Albanian nation when the Ottoman Empire was retreating from the Balkans whereas Serbia was coveting the lands inhabited predominantly by Albanians. Albanians believe that they are the descendants of Illyrians, i.e. the autochthons of the Balkans,

\footnotetext{
${ }^{1}$ Valery Kolev and Christina Koulouri (eds.) The Balkan Wars (Teaching Modern Southeast European History Alternative Educational Materials, Workbook 3), Thessaloniki: Center for Democracy and Reconciliation in Southeast Europe, 2009. p. 47. Online source: http://www.cdsee.org/jhp/pdf/workbook3 eng ed2.pdf, accessed on March 22, 2010.
} 
in contrast to the fact that Serbs came to the Balkans not until the sixth century. In arguing against the Serbian claim that "Kosovo is the Serbian civilization cradle", Kadare writes, "This is a blatant lie. No serious historian or reliable historical source has ever been able to provide evidence that the Serbs were the original inhabitants of Kosovo and that the Albanians were later immigrants. On the contrary, the Albanians were there from the very start. It is the Slavs who arrived later - indeed quite a bit later" (243). ${ }^{1}$ Therefore, when Serbia occupied Kosovo in 1913 and implemented anti-Albanian policy, it became a real enemy of the Albanian nation. 120,000-270,000 Albanians were killed and approximately 250,000 Albanians were expelled between 1912 and 1914. As pointed out by the Serbian socialist Dimitrije Tucović after he returned from the Balkan war, "Unlimited enmity of the Albanian people against Serbia is the foremost real result of the Albanian policies of the Serbian government" $(107-108) .^{2}$

The Kosovo intellectuals also played an important role in highlighting Serbia as the colonialist Other. Rexhep Qosja argues that Kosovo Albanians, instead of being considered as an ethnic minority in the former Yugoslavia, should have been viewed as half of the divided Albanian nation since 1913. He underlines that all the sufferings of the Albanians in Kosovo originated from the fact that Albanians were unwanted people on their own land. (1997: 207-232).

Therefore, the Kosovo problem is in essence a modern phenomenon, the crux of which is that both Serbs and Albanians have territory claim for Kosovo. As pointed out by Victor Roudometof, the ethnic conflicts in the Balkans were and are caused by national rivalries due to the reorganization of southeast Europe along

\footnotetext{
1 Ismail Kadare, "The Question of Kosovo" in Robert Elsie, ed., Kosovo in the Heart of Powder Keg. New York: Columbia University Press, pp. 233-250, 1997.

2 Dimitrije Tucović, Serbia and Albania: One Contribution to the Criticism of the Subjugation Policy of the Serbian Bourgeois (Srbija i Arbanija jedan prilog kritici zavojevačke politike srpske buržoazije). Belgrade: Radnička štampa, 1914. Reprint in 1974.
} 
nineteenth-century Western European nation-state models, and are not an Ottoman legacy. They are a consequence of modernization in an ethno-religious environment where the nonviolent implementation of the nation-state was impossible. ${ }^{1}$

It is worth noting that the Serbian Other has not always been presented or perceived as an evil colonizer over the past century. As has been observed by Patrick Artisien:

Up to 1948 the ideological bond uniting the two countries left Yugoslavia's 1945 re-annexation of Kosovo out of their respective agendas. Yugoslavia's expulsion from the Cominform that year provided Tirana with a platform from which to reactivate the 'unsettled annexation of Kosovo' issue; with Stalin's backing, the Albanian media gave extensive coverage to the 'persecution' of Albanians in Yugoslavia, and some high-ranking party members openly incited the Kosovo Albanians to rebel against Tito. ${ }^{2}$

During the 'honeymoon' years (1945-1948) between Albania and Yugoslavia, Serbs, as part of the Yugoslavian people, were described by the Albanian official propaganda as brothers and friends who selflessly assisted the Albanian people in their National Liberation War as well as the postwar socialist building, despite the fact that in Kosovo numerous ethnic Albanians were being persecuted for anti-Yugoslavian resistance. After the split between Albania and Yugoslavia in 1948, Albania boldly accused Tito's regime of revisionism and violation of human rights in Kosovo, but restrained itself from over-provoking Tito's regime, especially in terms of Yugoslavia's territorial integrity. That is why in the early 1990s Kadare accused Hoxha's regime of downplaying what was happening in Yugoslavia "where half the Albanian nation suffered atrocious oppression" (Albanian Spring 125). ${ }^{3}$ But as a writer, Kadare did not dare to touch upon the Kosovo question before the regime gave

\footnotetext{
${ }^{1}$ Victor Roudometof, "Nationalism, Globalization, and Orthodoxy: The Social Origins of Ethnic Conflict in the Balkans". Westport, CT: Greenwood Press, 2001.

2 Patrick F. R. Artisien. "A Note on Kosovo and the Future of Yugoslav-Albanian Relations: A Balkan Perspective," Soviet Studies, Vol. 36, No. 2, April, pp. 267-276, 1984.

${ }^{3}$ Ismail Kadare, Albanian Spring: the Anatomy of Tyranny (Nga një dhjetor në tjetrin), London: Saqi, 1995 (Reprint). The book was first published in 1991 in Paris by Fayard, translated into English and published by New Amsterdam Books in 1994.
} 
green light.

It was only after Tito's death in 1980 that Albania started to officially present Serbia as the colonialist Other, as reflected in the Albanian media. In responding to Serbia's suppression of the 1981 demonstrations in Kosovo, Albania published a series of articles which not only supported the demonstrators' demand for Kosovo republic and denounced Yugoslavia's military quelling, but also challenged the validity of treaties of Serbia/Yugoslavia's ownership of Kosovo (Zëri i Popullit, 1981). ${ }^{1}$

The change of Albania's policy toward Kosovo is evident if we compare Kadare's two visits to Kosovo in 1972 and 1980. Kadare visited Kosovo for the first time in 1972, but produced no writing at all, let alone the sensitive Kosovo problem. However, in November 1980, five months after Tito's death, when Kadare visited Kosovo for the second time, he had extensive exchanges of views with the Kosovo intellectuals, visited important cultural institutions such as the library, the publishing house, the film studio, the university, the theaters, etc. and expressed appreciation to Kosovo intellectuals' contribution to the reduction of differences between the Tosk (Southern Albanian dialect) and Geg (Northern Albanian dialect), as well as to the promotion of the their common national language and culture. In his subsequent article "In Kosovo, among the brothers", ${ }^{2}$ he described his happiness of being among the Kosovo brothers and expressed his gratification over the use of national flag at weddings and the high fertility in Kosovo. Together with his 1980s fictions analyzed in this chapter, Kadare contributed significantly to the enhancement of Albanian nationalist sentiment.

\footnotetext{
${ }^{1}$ Zëri $i$ Popullit (Voice of the People) was the most important official newspaper in Albania during the Communist regime. It continues to be the newspaper of Albanian Socialist Party. The articles were published on April 8, 1981.

2 Ismail Kadare, "In Kosovo, among the brothers" (Në Kosovë, midis vëllezërve) in Vepra 12 (volume 12 of Kadare's literary works), Tirana: Naim Frashëri, 1981.
} 
As for the Kosovo Albanians, the atrocities and ill-treatment they suffered during Karađorđević and Ranković times were unforgettable. Even after Rankovic's fall when Albanians were allowed to have their own provincial constitution and constitutional rights accordingly, they felt discriminated. Nevertheless, during the years between the fall of Ranković in 1966 and Tito's death in 1980, when the communist dogma of brotherhood and unity was advocated and Serb Chauvinism was curbed, the Serb-Albanian conflict was temporarily frozen. Though political intimidation and mistrust was still perceivable, as reflected in R. Qosja's work Death Comes to Me from Such Eyes, ${ }^{1}$ the mainstream media in Kosovo was presenting a rosy picture of good 'in-group' relations between Serbs and Kosovo Albanians, i.e. both being members of the big harmonious Yugoslavian family and holding positive attitudes toward each other. It was after the 1981 demonstrations that this rosy picture was broken. The persecutions against the Kosovo Albanians during the 1980s, especially the anti-Albanian policies during Miloshevic's time, further convinced the Kosovo Albanians that Serbia is definitely the evil Other they would never be able to live with under one roof.

As can be seen, the construction of the evil Serbian Other in Albanian media is basically politically oriented. Albania's role in the construction of hostile Otherness between Kosovo and Serbia is crucial. Given the international and domestic situations, Albania has responded differently to the predicaments and demands of the Kosovo Albanians, from being mute to atrocities to denouncing the human rights violation and finally to openly supporting the Kosovo Albanians' demand for independence. Albanian elite intellectuals, Ismail Kadare in particular, have played an important role in the shaping of the Serbian Other as colonizer, political persecutor and war criminal.

\footnotetext{
${ }^{1}$ Rexhep Qosja, Death Comes to Me from Such Eyes (Vdekja më vjen prej syve të tillë), Prishtina: Rilindja, 1974.
} 
On the other hand, the Serbian anti-Albanian nationalist policy was also an important factor in the deterioration of the relations between the two neighboring nations.

Many Western journalists and politicians tend to explain the Balkan ethnic conflict while invoking their mutual hatred ever since the ancient times. Such an interpretation assumes that the Balkan people are by nature belligerent and bound by infinite ancient hate. According to J. Revel and L. Hunt, "In many developed societies, the collective investment in memory is a response to the acceleration of history, to rapid social change, and to the problems of identity that such changes are pressing home with growing urgency" (quoted in Todorova 2). ${ }^{1}$ Kadare also portrays the Serb-Albanian conflict as an inheritance from their ancient hostility, particularly when the Kosovo crisis was at a high peak. But different from Western scholars, he aims to present the problem as the conflict from the native Albanians fighting against the Slav late-comers. In Kadare's works, epic stories are often invoked to support his idea, such as the Illyrian hero Muji fighting against Slavs in The File on H. and the legend of mountain fairies stopping wedding processions toward wrong a marriage in The Wedding Procession Turned into Ice. This is probably because, as W. McNeill asserts, "a nation or any other human group that knows how to behave in crisis situations because it has inherited a heroic historiographical tradition that tells how ancestors resisted their enemies successfully is more likely to act together effectively than a group lacking such a tradition" (6). ${ }^{2}$ Like the writers of the $19^{\text {th }}$ century Albanian National Revival Movement, Kadare resorts to myths such as history and linguistic arguments to claim the legitimacy of Albania's territory sovereignty over Kosovo. His narrative has exerted a powerful effect in shaping the Serbian colonialist Other and

\footnotetext{
${ }^{1}$ Jacques Reel and Lynn Hunt, eds, Histories: French Construction of the Past, New York: The New Press, 1995, 631. Quoted in Maria Todorova, ed. Balkan Identities: Nation and Memory. New York City: New York University Press, 2004, p. 2.

2 William McNeill, Mythistory and Other Essays, Chicago: University of Chicago Press, 1986.
} 
rally the Albanians around their national cause, as "it is evident that myth is a central aspect of collective experience. [...] The greater the density of myth, the easier it is for modern and post-modern communities to cope with challenges" $(30){ }^{1}$

Kadare's attitude toward Kosovo in line with Albanian government and his fictions regarding the Kosovo problem reveal to us the political nature of national identity and the important role of environment in national identity formation. Through the construction of the Serbian Other, Albanian people's consciousness of Self as a nation with an ancient history but miserable sufferings due to foreign invasion and occupation is immensely enhanced. It tells us how national identity is rooted in the cultural heritage and how that heritage can be manipulated. It is the political judgment of the domestic and international situation that determines when memories or mythology of ancient hate would slumber and when they would be activated and highlighted. The tendency to explain Serb-Albanian conflict exclusively in terms of the primordial manifestations of group identity would result in the misdiagnosing of its causes. As Sundhaussen commented, "In the Balkan space many factors come together ... and in their combination they create an inextricable knot" (Quoted in Balkan Identities 8). ${ }^{2}$

Among the many factors the Balkan policies of great powers have certainly been of primary importance. Maria Todorova is one of the prominent scholars who have noted the consequence of the intervention of great powers in the Balkan issues. She acutely points out:

Still, neither historic rights (based on the territorial zenith of the medieval Balkan states) nor issues of self-determination were, in the final account, instrumental in delineating frontiers. At the very most, these elements shaped the controversial and incompatible

\footnotetext{
1 George Schopflin, "The Function of Myth and a Taxonomy of Myths", in Myths and Nationhood. Edited by Hosking, Geoffrey and George Schopflin. London: Hurts \& Co, 1997.

${ }^{2}$ Sundhaussen, "Europa balcanica", 626-53, quoted in Maria Todorova. ed., Balkan Identities: Nation and Memory, London: Hurst \& Co., 2004.
} 
Balkan irredentist programs. The size, shape, stages of growth, even the very existence of the different Balkan states were almost exclusively regulated by great power considerations following the rules of the balance-of-power game. (169) ${ }^{1}$

In his works, Kadare has also reflected the role of the great powers in aggravating the Serb-Albanian conflict via sponsorship of some states and nationalist movements against others. For example, in The Palace of Dreams, he writes:

What's Russia got to do with those wretched epics?

Russia? I wondered that too, [...] In fact it's an exceedingly complex business, to do with settlements and transfers of population in the Balkans, and the relations between Slav peoples and non-Slav peoples, like the Albanians. In short, it directly concerns the whole map of the Balkans. For this epic, as I said, is sung in two languages, Albanian and Slav, and is connected with questions of ethnic frontiers inside the Empire. [...] Austria supports the non-Slav peoples, whereas the Slav's 'little father', the Tsar, is always on at our Sultan about the way the people of his race are treated. (167)

Particularly in his novel The Dark Year (1986), Kadare raised the question of the Albanian nation's unfair partition caused by the great powers, which cared nothing for the local people but their own share of sphere of influence in the Balkans. Thus the territorial boundaries of Balkan states, in this case the borderline between Albania and Serbia, did not result only from the fighting between the two hostile nations, but also from the international invention, which often worsens the Otherness between the involved nations. According to Maria Todorova, the geopolitical purpose of the great powers' intervention is camouflaged by the emphasis of the ancient Balkan hostility. Therefore she calls out for rational criteria to be applied to the Balkans.

It would do much better if the Yugoslav, not Balkan, crisis ceased to be explained in terms of Balkan ghosts, ancient Balkan enmities, primordial Balkan cultural patterns and the proverbial Balkan turmoil, and instead was approached with the same rational criteria that the West reserves for itself: issues of self-determination versus inviolable status quo, citizenship and minority rights, problems of ethnic and religious autonomy, the

\footnotetext{
${ }^{1}$ Maria Todorova, Imagining the Balkans. New York: Oxford University Press, 1997.
} 
prospects and limits of secession, the balance between big and small nations and states, the role of international institutions." $(186)^{1}$

It is desirable that the rational criteria be turned into the right solution to the Serb-Albanian conflict, and as a result, Ismail Kadare, who till now has sung hate songs against Serbia like the rhapsodist Gjorg in his Elegy for Kosovo, would finally be liberated from his historical task of constructing Serbia as the evil Other of the Albanian nation.

\footnotetext{
${ }^{1}$ Maria Todorova, Imagining the Balkans. New York: Oxford University Press, 1997.
} 


\section{CHAPTER 6 FROM OTHER TO MOTHER}

\subsection{Background}

From the four Others examined in the previous chapters we can see that Kadare's writings are in line with Albania's political development. As an astute and pragmatic writer, Kadare went with the political flow by producing 'proper' literary works, proper in the sense that they were compliant with the political agendas and served the political leaders of the time. This chapter focuses on Kadare's rhetoric created for the West in the post-Cold War environment and the rationale for transforming the West from the hostile Other to the dear Mother of the Albanian nation.

After the Second World War, Albania and the West viewed each other as the Outgroup Other. Albania's relationship with the West underwent a slow thawing. France was the first Western nation to establish diplomatic relations with the new communist Albania in 1946 and since then has maintained normal relations with Albania. Italy and Albania signed the Treaty of Peace in 1947, according to which Italy had to pay war reparations of five million US dollars to Albania. The Treaty cleared up the main obstacle that stood in the way of developing the bilateral relations, and in 1949 Albania established official diplomatic relations with Italy. In 1957, two years after Austria declared permanent neutrality, Albania and Austria established diplomatic relations. Then, after the Czech crisis in 1968, Albania, fearing the possibility of Soviet attack, started to adjust its foreign policy. "A new 
Chamber of Commerce was created to negotiate trade agreements with West European countries, and to organize Albanian participation in Western trade fairs" (24). ${ }^{1}$

The Albanian newspapers toward the end of 1960s and throughout 1970 had a sudden burst of reports on Albanian diplomatic activities in Western European capitals, and Albanian leaders' speeches underscored their "wish to maintain good, correct relations, trade and cultural exchanges with countries having different regimes". 2 As a result, by the end of 1970, Albania had established diplomatic relations with Western European countries such as Finland, Sweden, Denmark, Switzerland, Belgium, and Holland. Meanwhile, West Germany and Greece were also approached about the prospects of normalizing bilateral relations. This momentum of Albania's appearance on the Western diplomatic arena was further propelled by the need to counteract the increasingly obvious cooling down of Sino-Albanian relations during the 1970s and the need for advanced technology.

In the latter half of 1980s, Albania further moved toward its opening up to the West. In 1987, interested in West Germany's investment and high technology, Albania dropped the reparation claim and established diplomatic ties with West Germany. In the same year, the Albanian president Ramiz Alia invited Britain to open talks on establishing diplomatic ties, saying it was time to unfreeze the relationship after a break between the two nations 41 years ago. ${ }^{3}$

However, it was not until 1991 that Albania finally normalized relations with the two main Western countries, the USA and Britain. Both of these countries aimed to overthrow the Albanian communist regime. The USA refused to recognize Albania

\footnotetext{
${ }^{1}$ Gene Gregory. "Maoist Albania Desires Better Western Relations", Merce Sun-Star, Apr 26, 1971. Retrieved from http://news.google.com/newspapers?id=7TRcAAAAIBAJ\&pg=7400,6832945 on March 10, 2013.

${ }^{2}$ Ibid.

3 David Binder, "Albania planning West German Ties: Move Signals an Opening to West, but Coolness to U.S. and Soviet Continues." New York Times (1923-Current file); Jul 5, 1987; ProQuest Historical Newspapers: The New York Times (1851-2009) pg. 7.
} 
while taking Albania's unilateral cancellation of some unsubstantial prewar treaties as an alibi, whereas for Britain the Corfu incident exacerbated its relations with Albania. In 1946, both the USA and Britain opposed Albania's admission into the UN. Between 1949 and 1954, in conjunction with British intelligence, the CIA trained Albanian refugees and attempted to send them back to their homeland for the purpose of instigating a massive revolt against Hoxha's regime. Consequently, even though there were some improvements in Albania's relationships with some European countries during the 1970s and 1980s, the West in general, with the USA as the leader, was regarded by Hoxha's regime as an enemy. As shown in chapter two, the West was constructed in Kadare's works during the communist era as a hostile and immoral Other of Albanian nation. In Kadare's own words, somewhat exaggerated though, "A few years earlier, using the word 'agreement' for Europe would bring fatal punishment for anyone in Albania, leading to imprisonment or even execution. With Europe there was only one proper word, the one opposite to agreement, i.e. 'disagreement'” (2006: 7-8). ${ }^{1}$

In 1990, the waves of turmoil in the former East European socialist countries finally hit Albania. Albania was confronted with political realignment. The Albanian people, tired of political control and freedom restriction during the communist regime, especially the severe poverty in the 1980s after Albania's break with China, were eager to join the Western world for a better life. In December 1990, under the pressure of the demonstrations of students and workers, the government allowed the creation of independent political parties, thus ending the communists' official monopoly on power through the so-called negotiated revolution. The myth of “indomitable citadel of communism" fell and Albania officially turned to embrace

${ }^{1}$ Ismail Kadare, Identiteti Evropian i Shqiptarëve (The Albanians' European Identity). Tirana: Onufri, 2006. It is only 55 pages, written to claim the European identity for Albanians and refute Rexhep Qosja's view that Albanian nation, situated between East and West, does not belong totally to Europe. 
the rich and democratic West. To be accepted as an in-group member, Albania had to de-other-ize the West, i.e. the Western Other constructed during the communist regime had to be re-identified in the new political context. Therefore, over the last two decades, the previous out-group Western Other has undergone the process of re-identification among Albanians.

Albania's re-orientation toward the West can be seen from the top priority it gave to joining NATO and the European Union. In 1992, Albania joined the North Atlantic Cooperation Council, which was specifically created to strengthen institutional cooperation on the political and security issues between NATO members and the former Warsaw Pact countries. In 1994, it entered NATO's Partnership for Peace, which marks the beginning of Albania's process of accession into NATO. In 1999, Albania received a Membership Action Plan and in 2009 became a full member of the alliance. Meanwhile, in 1992, Albania signed a Trade and Co-operation Agreement with the EU, becoming eligible for funding under EU's Phare program. ${ }^{1}$ As a result of Albania's consistent efforts for more than ten years, the EU signed with it the Stabilization and Association Agreement in 2003, the first major step toward Albania's EU membership. In 2012, Albania's progress was evaluated by the European Commission and was given a conditional candidate status. $^{2}$ While Croatia is becoming a full EU member in July 2013, Albania and the other Balkan countries such as Serbia, Montenegro, Macedonia, Bosnia, etc. are hastening their steps to be officially admitted to the EU. The claim that they have European identity is being emphasized more conspicuously than ever before by the

\footnotetext{
${ }^{1}$ The Phare is short for Poland and Hungary: Assistance for Restructuring their Economies, a programme created in 1989 to assist Poland and Hungary in their democratic transition. Later on it expanded to cover ten central and Eastern European countries, including Albania. It is one of EU's three pre-accession instruments to support the applicant countries' efforts for joining the EU.

2 http://www.mfa.gov.al/index.php?option=com multicategories\&view=category\&id=3\&Itemid=65\&lang=sq Albanian government's website, accessed March 14, 2013.
} 
governments and the mainstream intellectuals of these countries.

However, as Samuel Huntington pointed out, "the crucial post-Cold War issue for the East European peoples was whether the West would accept their identification of themselves as part of the West" and "it depends on many factors, not only the stress of certain aspects such as one's original identity that links them to the people they desire to share the same identity" $(23) .{ }^{1}$ For the Balkan people, unfortunately, the rooted Ottoman legacy, the bloody ethnic conflicts and the perplexing mixture of Oriental and European traits in the region made the Balkans perceived by the West as undesired or unqualified to become an in-group member. In other words, though geographically integral to Europe, the Balkans is viewed as culturally alien. "With the reemergence of East and orientalism as independent semantic values, the Balkans are left in Europe's thrall, anticivilization, alter ego, the side within" (Todorova188). ${ }^{2}$

In terms of their response to the West's alienation of the Balkans, scholars of Balkan studies can be divided into two groups. One group, such as Maria Todorova, Milica Bakic-Hayden ${ }^{3}$, Dušan Bjelić ${ }^{4}$, Vesna Goldsworthy ${ }^{5}$, etc, raised their voices of criticism. The works such as Imagining the Balkans by Todorova in 1997, Inventing Ruritania by Goldsworthy in 1998, and Balkan as Metaphor: Between Globalization and Fragmentation edited by Bjelić \& Savić in 2002, etc. explored epistemologically how and why the derogatory image of the Balkans was created, pointing out that it is the West who constructed the Balkan Other in order to strengthen its sense of

\footnotetext{
${ }^{1}$ Samuel Huntington, Who Are We? The Challenges to America's National Identity. New York: Simon \& Schuster, 2004.

2 Maria Todorova, Imagining the Balkans. New York: Oxford University Press, 1997.

${ }^{3}$ Milica Bakic-Hayden, "Nesting Orientalisms: The Case of Former Yugoslavia" in Slavic Review. Vol. 54, No. 4, (Winter 1995), pp. 917-931.

${ }^{4}$ Vesna Goldsworthy, "Invention and In(ter)vention: The Rhetoric of Balkanization", in Balkan as Metaphor: Between Globalization and Fragmentation. Dušan Bjelić \& Obrad Savić (eds). Cambridge: The MIT Press, 2002. Vesna Goldsworthy, Inventing Ruritania: The Imperialism of the Imagination. New Haven and London: Yale University Press, 1998.

${ }^{5}$ Dušan Bjelić \& Obrad Savić, eds., Balkan as Metaphor: Between Globalization and Fragmentation. Cambridge: The MIT Press, 2002.
} 
superiority. The other group, in contrast, uncritically internalized the Balkan stereotypes and reproduced or reinforced these stereotypes in their works. This is particularly notable in the contemporary Balkan films. Comparing the Third Cinema, which had an alternative counter-Western ideology, Iordanova criticizes that "All the Balkan film makers seek, on the contrary, is to be admitted. But subversion and resistance do not grant admission. Concessions work better for them” (68). ${ }^{1}$

As a response to the derogatory images of the Balkans in the Westerners' eyes and the continuous alienation of the Balkans as Europe's inner Other, Ismail Kadare claims the Albanian nation's pure European identity. Arguing against those who emphasize the Ottoman legacy in Albanian culture, Kadare underlines that the Albanian nation originally belonged to Europe. He stresses that there is no benefit for Albanians to claim their half eastern and half western identity. In other words, Kadare views Albania's past under Ottoman occupation and communist rule as an aberration which never managed to destroy Albanians' original European identity. Kadare's claim is pragmatic in nature and therefore popular among the West-oriented Albanians. As explained in chapter one, Kadare had to change his personal identity to be qualified for the role of a leading intellectual in the new post-1990 circumstances. Through a series of interviews Kadare portrayed himself as a dissident. In the book Albanian Spring: the Anatomy of Tyranny, Kadare presented himself as a fighter for democracy. By reinterpreting or modifying some of his works written during the communist era and by producing new anti-totalitarian works, he further demonstrated his pro-Western political stand. The honors and awards he won in the West contributed to the consolidation of his popularity within his country. Nevertheless,

\footnotetext{
${ }^{1}$ Dina Iordanova, Cinema of flames: Balkan film, culture and the media, London \& Berkeley: BFI \& U California Press, 2001. The Third Cinema is a term coined against the so called first cinema and second cinema, i.e. the Hollywood production and the European films. It refers to the Latin American film movement in the 1960s-70s which decries neocolonialism, the capitalist system, and the Hollywood model of cinema as mere entertainment to make money.
} 
there is no lack of sharp or even vehement criticism of Kadare's remarks and

behaviors. The Kadare-Qosja debate is the best example of the anti-Kadare voices.

The debate has its origin back in 1997, culminated in 2006 and continues until today. ${ }^{1}$

The focal point as it turned out is whether Albanian people have a pure European identity.

Kadare hates to be accused as a writer who gained his fame due to Enver Hoxha's support, which was one of the major points of his quarrel with R. Qosja. In 2012, in order to show that he was pressured instead of protected by Enver Hoxha, Kadare filed a lawsuit against Hoxha's 92-year-old widow Nexhmije, in which he demanded the return of his manuscript of The Great Winter. However, rather than gaining Kadare any points, the lawsuit caused another round of criticism with regard to his personality. Critics noted Kadare's inconsistency in his statements on why the manuscript was given to Enver Hoxha as a gift. ${ }^{2}$ In a word, when the Balkans and Albania as a Balkan country are not being viewed positively by the West, Kadare

\footnotetext{
${ }^{1}$ According to Kadare's wife Helena, the quarrel between Kadare and Qosja started in 1997, when they received two letters from Qosja in an improper way. Qosja said it started in 1999 due to his criticisms of Helena's false account of history in her book. He admitted that he wrote letters to Kadare in 1997 where he said that he was surprised to see what Kadare said about the Albanian people suffering the collapse of the pyramid schemes in 1997. Kadare said in an interview that the Albanian people who were fleeing Albania burned down everything in order to show to Europe that they could no longer stay in their country and need to be accepted by Europe. Qosja said this remark is almost an insult to Albanian people, because they were not leaving while burning down everything, but fleeing the bad political situation, i.e. Sali Berisha's regime. He said that instead of protecting Sali Berisha's regime, writers should stand in line with the people. (Qosja's original reply regarding this question is: Unë i kam shkruar Kadaresë në atë letër se lexova një intervistë të Ismail Kadaresë që kishte dhënë në Europë, ku thoshte se shqiptarët që po ikin në vitin 1997 prej Shqipërie, po djegin çdo gjë për të mundur që t’i thonë europianëve që s'kemi ku rrimë atje, pranonani ju. Kjo ishte një fyerje e madhe për ata qytetarë të Shqipërisë dhe për Shqipërinë. Nuk iknin shqiptarët duke djegur dhe pjekur Shqipërinë, iknin prej situatës politike, regjimit të Sali Berishës. Dhe unë i thashë Kadaresë: shkrimtarët kurrë s'janë në anën e politikanëve për të mbrojtur dhunën e regjimeve, shkrimtarët janë vetëm në anën e popullit. Mbro popullin, jo Sali Berishën. The above information is taken from Rexhep Qosja's interview given to the Albanian newspaper Gazeta Mapo, "Marrëdhëniet me Ismail Kadarenë: Nuk jemi ndarë për jetë a vdekje" (Relations with Ismail Kadare: we are not split for life or death), published on December 10, 2011, http://www.peshkupauje.com/2011/12/rexhep-qosja-librat-e-rames-dhe-fevziut, accessed on Feb. 20, 2013.)

2 Kadare claimed the return of the manuscript based on the argument that it was "donated" under political pressure. Nexhmije's lawyers showed evidence that Kadare had very close and friendly relations with the Hoxha family. Donating the manuscript to Enver Hoxha, Kadare wrote, "To comrade Enver with boundless love from the author, in memory of the unforgettable days in Moscow in 1960, which further raised the honor of the country and the Party, whose epic will last forever." (Original text: Shokut Enver me dashuri të pakufishme nga autori në kujtim të ditëve të paharrueshme të Moskës 1960, të cilat ia ngritën edhe më lart nderin vendit dhe Partisë dhe epopenë e të cilëve do të vazhdojë përjetë".) Taken from http://shekulli.com.al/web/p.php?id=4856\&kat=100, "Kadare nuk po bën gjyqin tim, por gjyqin e vetes" (Kadare is not suing me but himself), an interview given by Nexhmije on September 27, 2012 to the Albanian newspaper Shekulli, accessed March 24, 2013.
} 
claims the European identity for his nation, while presenting himself as a democratic fighter and a victim of Albanian communist regime.

As a gesture to show his pro-Western stand, Kadare denies any personal or national connections to things that are not in accordance to Western values and culture. He continues to present the East as the Other, now in a broader sense: not only as the Other of Albania but as the Other of the West. In the meantime however, the West, represented by Europe, turns from the Other into an ingroup member of Albanian nation. Europe or the European Union is not merely identified from geographical, cultural and historical perspectives as the place where Albanian nation belongs to, but as Albania's Mother.

Two words are essential in Kadare's description of the rhetorically called European Mother: re-found and eternal. The first word indicates that the European Mother is re-findable. Instead of actively looking for her lost child, the Mother stays there passively to be re-found. The second word stresses that Europe's Mother status for Albania is eternal, no matter she is re-found or not. Focusing on these two words, I will examine Kadare's claim of Albania's European identity in his works such as The Three Arched Bridge, The Castle, The File on H., Albanian Spring: the Anatomy of Tyranny and The Albanians' European Identity, for a better understanding of the post-Cold War European Mother: why, when and how is Mother Europe re-found by Albania and what is the nature of the re-found Mother.

\subsection{The Re-found Mother}

In The Three Arched Bridge, Albania is described as on the verge of being snatched away from Europe by the emerging Ottoman Empire. The medieval Albania in the story was portrayed as part of Europe through the words of the 
visiting Western monk Brockhardt: "Ah yes, you are where Europe begins" (69). As a Catholic clergyman, the narrator Gjon was very concerned about Albania's imminent loss of European status.

I would sit for hours on end, contemplating the point where the Turkish Empire began. I could not believe it was there in front of me. I repeated to myself over and over again, like someone wandering in his mind, that what they call the lands of Islam began a few paces in front of me. Asia began two paces in front of me. What had once been more distant than the lands of the fairy-tales was now in front of our very noses. (137)

Here, Gjon's concern indicates that identity is rather unstable. Small nations like Albania on the borderline between the East and the West more often have to accept the identity imposed on them. What Gjon was afraid of eventually happened and as a result, Albania, together with other Balkan peoples, became part of the Asian Ottoman Empire. Gjon would not believe that it would take so long and would be so hard for Albania to return to Europe. After the collapse of the Ottoman Empire in the early $20^{\text {th }}$ century, Albania started the process of westernization, but the process was interrupted by World War Two, after which Albania was included into the new Eastern camp, i.e. the communist camp. Until now, after over twenty years' efforts of the latest wave of westernization, Albania is still shut out of the European Union.

National identity is largely defined by historical and cultural heritage, as modified by the intellectual and political leaders. It is also influenced by external interests and perceptions. In the course of national/ethnic identification, the intellectual upper class of the nation has played a critical role. Gjon, the narrator of The Three-Arched Bridge, is mentioned in Kadare's another novel The Palace of Dreams as the ancestor of the powerful Quprili family in the Ottoman Empire. Though Gjon was reluctant to become part of the Asian Empire which had a different religious belief, he was wise enough to understand the situation. Therefore 
he changed his surname into Quprili, a Turkish word for bridge, to commemorate the change of his and his nation's identity. In late 1980s, when the world order was being reshaped, Kadare, like the medieval Gjon and the intellectuals of the $19^{\text {th }}$ century Albanian National Revival Movement, was facing the challenge of his nation's reorientation. Kadare chose to identify with the West, and this is clearly reflected in his literary works. Albania's European identity is rare in Kadare's works before the 1990s. The Three Arched Bridge (1978) can be interpreted in a way as Kadare's first attempt to claim Albanians' European identity, though the interpretation is quite unreliable, because in late 1970s the clerics, particularly the Catholics, were still viewed as Albanian nation's traitors and their political orientation would be taken by the public as wrong. Later on, in Agamemnon's Daughter $^{1}$, Kadare explicitly expressed his political alignment with the West, through a dialogue between the conservative uncle and his Western-oriented nephew.

"It's obvious that you prefer the climate of Europe, since it's your model in every respect!"

"So what model should I have?" I used to retort. "Bangladesh? The Far East? Skanderbeg fought for a quarter of a century to snatch Albania out of Asia and to [re-]bring it into the European fold. What have you and your friends been doing? You've never stopped trying to push Albania back again!" (Agamemnon 43-44, Vepra XIII 331, italic emphasis is mine)

Here, unlike in his previous novel The Castle, where Skanderbeg is depicted as fighting for Albanian nation's liberty and independence, Kadare highlights Skanderbeg's contribution to fighting against the Ottoman for the sole purpose of bringing Albania back to Europe. This indicates that Kadare was becoming increasingly aware of the coming of a new era and was preparing himself and his

\footnotetext{
1 The novel Agamemnon's Daughter is claimed by Kadare to have been written in 1985 and smuggled to France in 1986, together with two other works that had anti-communist content. It was published in France in 2003. The conversation quoted here between the protagonist and his communist uncle was from the English version published in 2006, with only a minor change put in the brackets, after I have checked the original text in Albanian in the $13^{\text {th }}$ volume of Kadare's latest complete works.
} 
nation for the new alignment. Indeed, after the Cold War, Kadare has devoted himself to the job that the $15^{\text {th }}$ century Skanderbeg and the $19^{\text {th }}$ century Albanian National Revival intellectuals attempted to do, i.e. to re-bring Albania to Europe. As the literary prince of his nation, Kadare is doing his utmost in leading his compatriot Albanians on their way back to their re-found European Mother.

Kadare first called Europe "Mother" in 1991 in his work titled in English as Albanian Spring. After describing the five-century-long Turkish yoke and five-decade-long communist rule as two historical tempests that relegated the Albanian nation to the East, he wrote:

Today, at century's end, the orphaned nation which has long borne a heavy cross is knocking at the gates of Europe - at the gates of her mother, who has always treated her as a stepchild, and who, despite her claims of Christian charity, has not been kind to the waif. (9, italic emphasis mine)

The blaming tone is obvious. Europe is presented as a guilty mother who abandoned the Albanian nation in the $15^{\text {th }}$ century when it was still a child. But unfortunately, after five centuries, when the once-abandoned child is now knocking at her Mother's gates, Mother is not opening her arms to welcome the child back. In other words, Europe did not only abandon Albania, but also refused to accept it after being re-found as Mother.

Then how can Albania get accepted by her re-found Mother? Seeing that it is to no avail to claim Albania as a victim sacrificed by Europe in fighting against the Ottoman Empire, Kadare believes that religion would play an important role in Albania's return to Mother Europe. Thus the Albanian nation is described as knocking at the gates of Europe while bearing a heavy cross, the symbol of Christianity. No wonder in Albanian Spring, Kadare predicted the change of Albanian people's religious belief, claiming that "Albania will most likely embrace Christianity" and 
"Islam, which arrived late in Albania in the baggage of the Ottoman overlords, will weaken - first in Albania, and then in Kosovo (34)", because he believes that

In this way, one evil (the 1967 prohibition against religious practice) shall give birth to good. Albania will carry out a great rectification of history that will hasten its union with the mother continent - Europe. (Albanian Spring 34)

Of course, what Kadare predicted has not happened, and it doesn't seem possible to happen in the near future. Even if this had happened, it would be unimaginable that Europe would have accepted Albania, because, as Kadare also knows for himself, it is not Albania's religious identity that affects Europe's decision. Then why is the Albanian nation so eager to claim its European identity, when Europe is aloof in a sense and sets a lot of conditions for its admission? Kadare himself gives the answer.

The Albanian nation has the most pressing need to be integrated with Europe. For a long time now the people have understood that she cannot be kept apart, like an orphan, but must ally herself with her European family, in keeping with her own dignity. (Albanian Spring, 111-112)

So, it is clear that what really matters in the post-communist reconstruction of Albanian identity is the need to enjoy an easy, rich and liberal life like the westerners, in Kadare's words, to live with dignity. Because this cannot be achieved by Albania itself in isolation, as advocated by Hoxha's regime in order to keep its economical and political independence, Albanians have to identify with the strongest for progress. It is believed by Kadare and most Albanians that joining Europe can help Albania get financial assistance and technical support to make progress toward a better life. ${ }^{1}$ Here, what Europe or the European Mother continent really refers to is the political entity of the European Union, or as we will later see, the expanded Euro-Atlantic family, i.e.

\footnotetext{
${ }^{1}$ According to "State of Play of EU Accession process for Western Balkans Candidate and Potential Candidate countries", Albania has received since 2007 EU financial aid under the instrument for pre-accession assistance (IPA). The allocations for $2007-2012$ are $€ 61.0, € 70.7, € 81.2, € 93.2, € 95.0, € 96.9$ respectively. Retrieved from http://www.europeanforum.net/uploads/news/wb taskforce on eu enlargement background briefing country overview_en.pdf, March 242013.
} 
the EU plus the USA. Kadare, as well as the other Albanian intellectuals involved in the debate regarding the Albanian nation's European identity, uses "Europe" and "European Union" interchangeably.

Once the Mother that will benefit the Albanian nation in its post-communist development is re-found, it is important to attract Mother's attention and get accepted. According to Kadare, the following things are essential to achieve this purpose:

First, Europe should be reminded of the debt it owes to Albanian nation. Kadare laments the tragic fate of Albanian nation, where Europe is presented as a guilty Mother who abandoned her child. He stresses that it's high time for her to make up her historical mistake by integrating the Albanian nation in its fold.

Now the Albanians have become aware that they are one of the oldest peoples of Europe, and that they deserve a better fate. Albania has had every chance of becoming one of the most prosperous and free countries on the continent: not only has she not achieved that, but by a dreadful paradox, as if to complete her tragic history, she has been deliberately severed from the peoples of Europe. (Albanian Spring 109)

I should like to add that the family of European peoples should be a little more attentive to that nation whom history has treated with great severity. By helping that country escape the fate which has weighed her down for so long, and in making her an integral part of itself, Europe can make up for its past indifference. (Albanian Spring 114)

The European Mother owes Albania not only because she abandoned the child, but also because she was protected by the child from the Ottoman invasion. This is obvious when we compare Kadare's work The Castle published in 1970s and the version published after 1990, which was re-titled as The Siege. In the latter versions, the Albanian people's heroic resistance under Skanderbeg against the Ottoman invasion is highlighted from the angle of Christian-Muslim clash-of-civilizations, i.e. the Albanian contribution to the survival of Christendom. For example, when describing the scene of soldiers seeing Skanderbeg leave the castle with the old and 
some of the women and children, Kadare changed the names of the places, with obvious implication that the resistance war was fought for the purpose of defending Christianity.

From look-outs on our towers we watched them climb up to the Plain of the Cross, then we saw them re-emerge on the Evil Slope and finally disappear into the Windy Ravine. (The Siege, 4, Compare: the underlined bold emphasis mine, the same with the following)

We watched their winding procession dwindle away. They were seen on the table land of the sheep, climbed the steep slope, and at last were at the Pass of the Wind. (The Castle, 8)

In post-90s version, the castle's image has also changed in the eyes of the Pasha, general of the Ottoman army. The author finds it important to emphasize the religious identity of the castle.

On this occasion, the citadel that soared up before him looked particularly gloomy, like most of the fortresses of the Christians. There was something odd, or even sinister, in the shape and layout of its towers. (The Siege, 6) Compare:

This time it was a gloomy castle towering there in front of him. There was something unnatural, almost ill-omened, in the construction and arrangement of the towers. (The Castle, 9-10)

He glanced up at the cross on the top of the citadel's church. Then at the fearsome banner, the two-headed black eagle whose outline he could barely make out. The vertical drop beneath the East Tower, the wasteland around the gallows, the crenellated keep, all these other sights gradually grew dark. He raised another look at the cross, which seemed to him to give off an Compare: eerie glow. (The Siege, 7)

He wondered who had been the architect of this castle, and how it was possible for everything to be constructed the wrong way there, ranging from the spot they had chosen to set it up, to its flag hoisted upon the first tower - an awe-inspiring red flag with a fearsome double-headed black bird in the middle. (The Castle, 10)

Albanians refused the conditions offered by the Ottomans, and this is described in the new versions not only as patriotic act, i.e. keeping the eagle, but more importantly as their determination of remaining faithful to the cross. 
Our answer was short and firm: neither the eagle nor the cross would ever be removed from our firmament; they were the symbols and the fate we had elected, and we would remain faithful to them. And so that each of us may keep his own symbols and fate according to the dispositions of the Lord, they had no alternative but to leave. (The Siege, 20)

Compare:

When they asked to know our terms, we demanded only one thing: that they take down their tents and go back to the way they had come, for the weight of their army was heavy on our soil. (The Castle, 20)

Also, when the head of foundry talked proudly about the cannon's effect of spreading panic among the besieged, the Quartermaster (intendant-in-chief in The Castle, Pavle Qesku's translation) commented on the greater importance of the cannon: intimidating the whole Christendom. In this way, Albania is portrayed as the front line of the war between East and West, victim to the powerful weapon in order to protect the West. In other words, the castle is no more a legend of Albania's indepence, but a legend of Albania's contribution to the West.

"It's very important," the Quartermaster agreed. "And I'm not thinking only of those wretches. The whole of Christendom trembles when it hears speak of our new weapon. It has Compare: already become a legend." (The Siege, 38)

"It's very important," said Muhedin thoughtfully. "Even now they have made a legend of their castle." (The Castle, 35)

When Kadare finds it necessary, he adds whole paragraphs to stress the nature of the war Skanderbeg fought against the Ottomans. The religious symbol of the Holy Cross, and the symbols of East and West, respectively the moon and the sun, are very often used by the author to convince the readers that the war was in essence the clash of the two civilizations.

The moon had not yet risen. It struck him as rather odd that the Christians, having seen Islam take possession of the moon, had not promptly made their own emblem the sun, but had taken instead a mere instrument of torture, the cross. Apparently they weren't as clever as people claimed. But they had been even less bright in times when they believed in 
several gods. (The Siege, 7)

As can be seen, Kadare attempts to make his novel an Albanian cousin to Orhan Pamuk's stories of symbolic clashes between Franks and Turks. ${ }^{1}$ In his work The Albanians' European Identity published in 2006, Kadare again emphasizes Skanderbeg's contribution to holding back the Ottoman army and Skanderbeg's Europe-wide fame as the temporary savior of Christendom. He believes that the sense of guilt and debt will push the Mother to feel obliged to pay back Albanians in one way or another. In The Albanians' European Identity, Kadare claims that NATO's bombing of the former Yugoslavia in 1999 is an act of Atlantic Europe's acknowledgement of Albanians' friendship to the West. NATO's military operation is cast as a result of Europe's regret and its payment of debt to Albania.

It seems that the continent Mother, repenting for the long forgetting, eventually recalled the abandoned people. (10)

Second, America's role in the Albanian nation's future, including the acceptance of Albanians by the re-found European Mother, should be highlighted. To Kadare, the European Mother is, to be more specific, the European Union plus the United States or the EU plus NATO. Kadare's concept of Europe seems to correspond to Richard Holbrooke's statement that "the United States is not in but of Europe". 2

Kadare's awareness of the key role of the US for Albania can be seen from the letters he wrote in 1991 after having settled down in Paris, respectively to American president Bush, French president Mitterrand and Czechoslovakian president Havel, published in his work Death Befell and We Saw Each Other - Diary for Kosovo, Articles and Letters. In the letter to the American president Kadare focused on two

\footnotetext{
${ }^{1}$ Orhan Pamuk is a Turkish novelist, screenwriter, academic. He won the Nobel Prize in Literature in 2006. His books are characterized by a confusion or loss of identity brought on in part by the conflict between Western and Eastern values.

${ }^{2}$ Quoted in P. H. Liotta, Dismembering the State: The Death of Yugoslavia and Why It Matters, Lanham of Maryland: Lexington Books, 2001, p.15.
} 
things: 1. asking the U.S. to forgive the anti-American stand of the Albanian Communist regime and to continue to help the Albanian people, because they feel deep gratitude toward the United States; 2. asking the U.S. to correct the European powers' mistake of dividing Albanian nation into two halves, i.e. returning Kosovo to Albanians. The other two presidents were also asked to sympathize with Albanians' tragedy of losing Kosovo and give their supports to the Kosovo liberation. One small detail worth noting is the dates of the letters: the letter to Bush was written on September 11, 1991, whereas the other two were written on September 12 and September 14. It indicates that America as the only superpower after the cold war is considered by Kadare the number one place Albania should identify with.

Most evidently, in his essay The Albanians' European Identity, Kadare mentions six times Europe as Atlantic Europe, and puts Europe and the United States together three times to indicate NATO. In the 408-word long first part, for example, Kadare uses three times the epithet "Atlantic" for Europe. Talking about Europe in Albanians' eyes after the dramatic changes in early 1990s, about the Albanians' reaction to the West's intervention of the 1997 Albanian riot, and about NATO's intervention of the Kosovo conflict in 1999, Kadare writes:

From that time on, Europe, more exactly the Atlantic Europe, did not stop being the major vexation of Albanians. Their view of it (Atlantic Europe) shifts from hopefulness and hopelessness, like a sprinkler which turns frequently between cold and warm. (8)

No single bullet was fired against the Euro-Atlantic army. It was the first time in the Albanian history for such a thing to happen. It was big evidence: touching evidence, that the army landing from the air and the sea was called by the Albanians as their own. (9)

Two years later, as a reply of (Albania's) good understanding, the unbelievable thing happened. The same Euro-Atlantic army, with aircrafts, rockets and bombings, intervened to liberate the outside Albania, i.e. Kosovo. (10)

Apparently, the Albanians feel more grateful to the United States than to Europe, 
because without the American support, Kosovo would not have been able to get out of Serbia's control. While Kadare and other Albanians accuse Europe for its past dismemberment of Albania, they have nothing but gratitude toward the U.S. Therefore, Kosovo's streets were named after Bill Clinton and Madeleine Albright, and thousands of Albanians named their children Bill and Hillary. In 2007, when Bush visited Albania, he was greeted as the liberator of Albanian nation. Clinton's statue in Kosovo and Bush's statue in Albania demonstrate not only Albanian nation's gratitude to the U.S. but more importantly their political orientation and alignment. Without the epithet "Atlantic", the re-found European Mother's value would be depreciated. In other words, America is an extremely important part of what Kadare rhetorically calls the European Mother. If the European continent can be metaphorically described as the biological mother to the Albanian nation due to geographical position, then the U.S. could be described as the God Mother, the one who sponsors the Albanian nation in the new political baptism.

Third, it is important to keep in mind that the re-found European Mother is standing at her gate to be pleased by her child. In Kadare's view, the key point to please the Mother is to identify totally with the West. This is where he differs from Rexhep Qosja, who claims that the Albanian identity is composed of the heritages of different historical periods, including the Ottoman heritage, i.e. the Islam religion and culture. Though Kadare claims that the three major religions (Islam, Catholic, Orthodox) practiced by Albanians should have equal positions, he actually discards everything related to Islam and the East. Kadare's radical "all or nothing" political tendency initially manifested itself, as discussed previously, when he predicted in 1990 that the whole Albanian nation, Kosovo Albanians included, would convert to Christianity. In The Albanians' European Identity, Kadare makes his point of view 
more explicit. He condemns any acts that might be interpreted as Albania's identification with the East, particularly the Islamic world. In Rexhep Qosja's words, "Ismail Kadare raises his voice against any contacts of Albania with the Near East, Middle East and any Muslim-populated countries". ${ }^{2}$ Indeed, Kadare condemns anything that indicates Albania's relationship with Islam, such as Albania's participation in the Islamic League Conference, the erection of statue of the Ottoman chieftain as the founder of Tirana city, etc.

Immediately after the first enthusiastic wave about Europe, even in the middle of it, it was never clear what pushed the first democratic government to make a counter move. Like a blind bird, an Albanian delegation flew to Jeddah, a flight after which Albania woke up in the Islamic League. (11)

The indirect nostalgia that is nowadays appearing among us for Ottomanism is not only surprising, but, first of all, obscene. [...] The statue erected for an Ottoman chieftain in 2001 in the center of Tirana, who was allegedly declared as the founder of the city, has been the biggest insult for the country's capital city, for the Albanian history and consciousness. (52)

While calling the Ottoman chieftain with Albanian origin as a traitor of the Albanian nation and denouncing the erection of statue as a humiliation for the nation, Kadare extols the erection of the Christian saint Mother Teresa's statue in the city of Shkodra, commenting it as evidence that proves Shkodra to be the center of Albanian civilization, i.e. the European Christian civilization. He condemns those who tried to stop erecting Mother Teresa's statue, labeling them Islamic fanatics. For Kadare, Albanian Muslims should in no way be linked to the East. Seeing that it is impossible for Albanian Muslim majority to turn into Christians, Kadare stresses that "the program of a European Albania is inseparably related to a Muslimism which is simultaneously national and European" (34). In other words, it should be emphasized that the Albanian Muslims are European Muslims. Therefore Kadare presents the

\footnotetext{
1 Rexhep Qosja. "Rrëshqitje politike dhe intelektuale" (Political and intellectual folly) Shqip, May 6, 2006.
} 
Albanian Muslims as historically suppressed by the Ottomans and nowadays killed by the Taliban, i.e. the West's enemy.

In case of irritated conflicts with the Ottoman Turks, Albanians were on the front line. Having the same religion with the ruler didn't blur their idea of freedom. [...] The nightingales that were unfairly gossiped in the Albanian Parliament in 2006 belonged to one of the martyr families. Thirteen sons of this family that served as officers were hanged within a day by the ruler of the same religion. Likewise, four Albanians were killed by the Taliban on March 13, 2006. And there are hundreds and thousands of other examples. (50)

Rexhep Qosja's mistake, according to Kadare, is acknowledging the Ottoman heritage as part of Albanian culture. Qosja's view that the geographically in-between Albanian nation has integrated both Western elements and Eastern elements in its culture is mis-interpreted by Kadare as "neither nor". He points out that a "neither nor country" status does not benefit the Albanian nation at all. He accuses Qosja and some politicians for not identifying totally with Europe.

These politicians, instead of focusing on the urgent major issues in front of the Albanian nation: the welfare, entrance into Europe and status of Kosovo, get lured by meaningless phantasm, [...]. To worry about how West and East can get along well, how to play the role of a mediator in the US-Iran disputes, in nuclear energy, can be called in a simple case as a daydream, but in a bad case as political corruption. (57)

The reason Kadare is against such Qosja identifying with both East and West is that he believes that Europe, more accurately the US and Europe, would not be happy to see the slightest sign of Albania turning its head toward East. Moreover, he believes that Mother Europe would be happy to receive gifts, especially gifts that would signify the West's superiority and its victory over the East. Thus toward the end of his essay, Kadare imagines Albania together with the other Balkan countries lining up at Europe's checkpoint for entrance, carrying Turkey as a trophy. In other words, Turkey, once such a mighty Ottoman Empire which lusted for the occupation 
of Europe, is now aspiring to become part of Europe. And Turkey's application for joining the EU is regarded by Kadare as a remarkable contribution of the Balkan peoples to Europe, not Turkey's own wish.

Here is the epilogue: the Balkan peoples are lined up in front of the Europe's gate. Aside is Turkey, the core of the past horrible empire. For five centuries she thought that she was bringing the Balkan peoples grabbed from Europe toward her own continent. But what do our eyes see now? An unbelievable thing. Indeed there is a trophy, but not the one as believed. It's not the Balkan peoples that Turkey is bringing as captives toward Asia, but on the contrary, it is they who are bringing as a trophy the old lady of Turkey.

Naturally, Turkey is not a hostage in the literal sense. Naturally she herself is seeking, even insisting upon, admission into Europe. Naturally she, even as she cursed and threatened Europe, was secretly seduced by it. And this is the greatest triumph of Europe. (60-61)

To sum up, the European Mother is re-found in the post-Cold-War world order, out of the Albanian nation's pragmatic need. The Mother should not be understood as confined to the European continent, but as extended across the Atlantic Ocean, in which the US plays the leading role. According to Kadare, Europe is a historically guilty mother who is supposed to make up her past mistakes. The European army sent to Albania to restore social stability in 1997 and NATO's bombing of the former Yugoslavia in order to solve the Kosovo problem are considered Europe's compensation for Albania's loss. Kadare believes that in the course of being tested by the re-found Mother for Albania's qualifications of being integrated into the West, it is extremely important to please the Mother with two things: one is clearly and fully identify themselves as purely European, and the other is emphasize Albania's contributions to Europe, namely holding back the Ottomans in the $15^{\text {th }}$ century and carrying the modern Turkey as a trophy to Europe.

\subsection{The Eternal Mother}


In the novel The File on H., Kadare identifies the modern Albanian epic songs with the ancient Homeric epic. He uses the similarity between ancient Greek language and Albanian language, the dress of the Albanian highlanders that is identical to the dress described in the Homeric epic, the gestures of the Albanian rhapsodists that reminds the Irish scholars of Homeric epic, etc. as evidence to prove that Albanians were indigenous to this European land, in order to Otherize Serbians as late comers and foreigners of Asian origin. By emphasizing the Greek origin of European civilization and the close contact between the Illyrians and the Hellenics, Kadare places Albania safely into the European fold. He uses every chance available to highlight the ancient history of Albanian nation in Europe, as evidence to demonstrate that Albanians are more European and more civilized than Slavs, or even older than the Greeks. For example, in The Three-Arched Bridge, Kadare expresses his idea through the narrator's explanation to a Western monk about the origin of the names of the Greek gods.

I told him that the names Zeus, Dhemetra, Tetis, Odhise, and Kaus, according to our monks, stem from the Albanian words $z \ddot{e}$, "voice," dhe, "earth," det, "sea," udhë, "journey," and haes, "eater". (70)

To Kadare, the primordial Europeanness of the Albanian nation is essential and perennial. He insists that the European identity of Albanians would never change, even after a five-century long occupation by the Asian ruler, even after the majority of the nation has converted to Islam religion. In The Albanians' European Identity, Kadare refutes Qosja's opinion that Albanian identity has been inevitably influenced by the Ottoman rule, saying that:

Arguments that the fate of Albanians is conditioned by different occupations are rather untenable. Most countries of the continent, from Greece to the Baltic countries, have been occupied for most of the time. However, it has not cut their identity into halves. (15-16) 
If Kadare's works before the 1990s with contentions regarding the Albanian nation's immemorial history in Europe and their contributions to the European civilization can be viewed as of the nature of nationalism, then his post-Cold War insistence on Albanians' European identity is more a reflection of his new political alignment. In order to make his pro-Western orientation sound less political, Kadare dedicated the third part of his essay The Albanians' European Identity (pp. 18-24, totally seven parts and 56 pages) to argue for the Albanian nation's eternal Europeanness from the following perspectives:

Kadare uses Albanian language as the first argument to claim the pure European identity of Albanians. It is not only ancient but also immutable, due to its strong self-protection mechanism.

The Albanians are among the most ancient people of the European continent, an autochthonous people, just like the Albanian language has been recognized by the greatest linguists as one of the 10 or 12 foundational languages of the continent. (20)

The machinery of the Indo-European languages of the Balkans was much stronger than that of the Ottoman language, which belonged to another galaxy. The Ottoman cannons destroyed the local castles one by one, but the Ottoman language merely scratched at the stubborn languages of the locals". (26)

Then Kadare employs Albania's geographical position as an indisputable argument to support his claim that Albania belongs to Europe. He stresses that Albania is not on the borderline between East and West, thus less dangerous to be labeled as non-European than Greece, Bulgaria and Macedonia.

Geography, the most stubborn thing in the world, is the first to testify to the Albanians' European identity. Such is the zeal of those who want to deny even this stubborn fact, that one gets impression Albania is located on the edge of Europe and that after it Turkey, or Asia begins. Meanwhile, when one looks at the map, one notices that there are at least three other states separating it from that border: Macedonia, Greece, and Bulgaria. Not to mention that which they refer to as "European Turkey". (20-21) 
The third argument Kadare offers is the simple fact that "Albanian people are white race, like all the other peoples on the European continent (21)". This point of view is caught by Qosja and criticized as racist.

Afterwards, Kadare argues from historical perspective, highlighting the European identity of the pre-Ottoman Albania and the medieval Skanderbeg's contributions to Europe. The Albanian Kanun and the Epos of Heroes are also listed as European, parallel to Epic of Digenis Akritas, Song of the Nibelungs, Song of Roland, Poem of the Cid, and the Nordic Sagas. Even the early bilingual literature, written between 15-17 centuries in Albanian and Latin, the Latin alphabet of Albanian language, as well as the double-headed eagle adopted on the Albanian national flag when it declared independence in 1912 are all taken by Kadare as evidence for Albanians' European identity.

At the end of this part, Kadare asserts, that as a result of all the mentioned factors, and touched by Albania's "tragic yearning" for the "lost Europe", Mother continent felt a burst of nobility and recognized the double-headed eagle, acknowledging Albanians as an independent European nation.

In a word, Kadare contends that, despite the history of being grabbed away to Asia for five centuries and the fact that there is remarkable Ottoman heritage in Albanian culture such as Islam religion, Albania's European identity is preserved and unchanged. Kadare attributes the immutability of Albania's European essence to factors such as language, geography, race, history, culture, etc., which according to him are unbreakable or undeniable.

\subsection{Discussion}

As a nation situated between East and West, Albanians have to constantly face 
the choice of identity. In order to survive and live a better life, they have to side with the stronger. The relationship between the Albanians and the Ottomans when the latter was in their good old days epitomizes the Albanians' pragmatism.

\begin{abstract}
Albania in the Turkish times became richer and wealthier than ever [...] This is the reason for the ties between the Albanians and the Turks: the Albanians found in the Turks that which their heart desired: possessions, honor, arms, horses, plunder as much as they desired, and freedom as much as they needed; and the Turks found in the Albanians that which they desired: courage, loyalty and ungrudging bloodshed (Sami Frashëri 19-21).
\end{abstract}

Sami Frashëri, the most influential figure of the $19^{\text {th }}$ century Albanian Renaissance, gave the above account in his famous book Albania - What it was, what it is, and what will become of it, which is considered the manifesto of Albanian Renaissance. While justifying Albania's history of mutual benefit alliance with the Ottomans, he warned Albanians of the dangers they were in, the biggest of which came from the collapsing Ottoman Empire itself. He urged the Albanians to get away from the Ottoman Empire and establish an independent republic of Albania according to the Western democratic model. Sami Frashëri's message is clear: get a clear understanding of the situation and associate with the powerful.

In early 1990s, Albania experienced another drastic change of world order: the collapse of communism. Throughout 1990, thousands of Albanian citizens tried to flee the country through Western embassies. Kadare sought political asylum in France in the same year. In 1991, the world was astonished to see the photos of thousands of Albanians fleeing aboard ships to Italy. These run-away waves and the pulling down of Enver Hoxha's statue mark the start of Albania's second westernization in its modern history. The stereotype of the Western Other imposed on them by the

\footnotetext{
${ }^{1}$ Sami Frashëri, Shqipëria, ç'ka qenë, ç'është, e ç'do të bëhet (Albania - What it was, what it is, and what will become of it)? Bucharest: Shoqëria Dituria, 1899; 3rd ed. Tirana: Kristo Luarasi, 1924 (first published in 1899). 
communist propaganda was abandoned overnight; instead they started to view the West as a paradise-like place. Their national pride established during the communist regime was destroyed. Sami Frasheri's question "Albania - What it was, what it is, and what will become of it?" reappeared demanding for an urgent reply.

According to the social identity theory, if a group with which an individual identifies is less highly valued than relevant out-groups, the individual becomes motivated to improve the group's standing (Tajfel, 1986). ${ }^{1}$ This finding has been proven true by the Albanian people's desire to change their negative image. For example, Mother Teresa is regarded as their national pride. ${ }^{2}$ As has been noted by Gëzim Alpion, "Through her, Albanians could tell the world that they should not be judged only on the basis of their poverty, that poor as some of them are, they are also an immensely spiritual and humanitarian people who "can produce inspiring figures of world stature"" (53). ${ }^{3}$ Similarly, as shown in the first chapter, the popularity Kadare regained in Albania after he won the International Man Booker Prize also has to do with Albanian people's motivation of improving their international standing. As for Kadare himself, we can see from his speech at the award ceremony that he is also highly concerned about the image of the Balkans, Albania in particular.

The Albanians' European identity is an important point Kadare makes to improve Albania's standing and its chance of joining the EU. In claiming the European identity, Kadare uses all kinds of evidence for argument. However, a critical reader will find his arguments in rather stark contrast to what he wrote in his previous works. For example, Kadare calls geography a stubborn argument for Albania’s European identity, but what is presented in The Three-Arched Bridge is Albania's unstable geographical

\footnotetext{
${ }^{1}$ Henri Tajfel (ed.) Social Identity and Intergroup Relations. Cambridge, UK: Cambridge University Press, 1982. Smith, Anthony. The Ethnic Origins of Nations, Oxford: Blackwell, 1986.

${ }^{2}$ Mother Teresa was born in Macedonia to an ethnic Albanian family. She tried several times between 1960s-1980s to obtain permission to visit Albania but her requests were turned down. She visited Albania for the first time in 1989 and became a national hero in Albania shortly after that.

${ }^{3}$ Gëzim Alpion, Mother Teresa: Saint or Celebrity? London and New York: Routledge, 2007.
} 
belonging decided by occupation, i.e. becoming part of Asia due to the Ottoman occupation. He uses Albania's early links to Christianity as evidence for Albania's European identity, but what we see in Doruntine is a Christian Other attempting to crush Albania's national identity besa. He argues that the Albanian nation's European identity has never changed, but in The Palace of Dreams he portrays the powerful Albanian family the Quprilis as changing their identity by getting a Turkish surname and converting to Islam. Also in Chronicle in Stone, Kadare shows to the readers his hometown with an Islam culture, which contradicts his theory that the Albanians' original identity would never change. In other words, Albania's political and cultural identity has been presented in Kadare's works as fluid and unstable, an outcome of foreign invasions. Even if the Western Other was not constructed voluntarily by Kadare, it would be illogical for Kadare to believe in Albania's un-touched European identity. Claiming the European identity for the Albanian nation or turning the previous European Other into dear Mother is a corollary of pragmatic philosophy. It is Kadare's echo to Sami Frashëri's pragmatic call that Albanians should side with the stronger.

Modern theorists tend to interpret national identity as a myth. By his theory that nations are "imagined communities",, Anderson tells us that nation is what we think we are and what we wish to be. Anthony Smith claims that nation is a modern

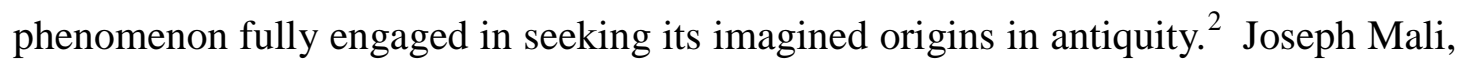
Stathis Gourgouris, etc. have noted that myth is always co-incident with history. ${ }^{3}$ Myths, after all, as said by George Schopflin, "structure our thinking and provide insight into collective motivations; they affect the nature of causation through their

\footnotetext{
${ }^{1}$ Anderson, Benedict. Imagined Communities. London and New York: Verso, 1991.

2 Anthony D. Smith, National Identity. London: Penguin Books, 1991.

3 Joseph Mali, Mythistory: The Making of a Modern Historiography. Chicago: University of Chicago Press, 2003. Stathis Gourgouris, Does Literature Think? Literature as Theory for an Antimythical Era. Stanford: Stanford University Press, 2003, p.43.
} 
power to structure collective thinking and behavior" $(30){ }^{1}$

Like many other Balkan writers, Kadare utilized myth as a key narrative style. In creating the myth that Albanians are totally European, Kadare reinforces the myth of Skanderbeg, highlighting Albania's role as Antemurale Christianitatis (Latin words for the Bulwark of Christianity) against the invading Turks. The changes he made after 1990s to his novel The Castle are good evidence for Kadare's efforts in this respect. Moreover, to glorify Albania's history within the Ottoman Empire, Kadare invented another myth: Albania's role as Europe's commando who conquered the Ottomans from within:

If there ever was a historical destiny for them [the Albanians], it is not that of a mediator. Against their own knowledge, against the knowledge of Europe itself, destiny assigned to the people of the Balkans, Albanians included, the role of Europe's commandoes, right in the heart of the Ottoman Empire. As such, they have always been, though suffering, at the root of Europe. (2006: 61)

In this way, Kadare presents Albania as never disconnected totally from Europe. The period Albania was part of the Ottoman Empire is reinterpreted as a time Albania was carrying out its mission without self-consciousness and without Europe's knowledge.

Yet, in reality, returning to Mother Europe, in Kadare's own words, is a long and painful journey (60). ${ }^{2}$ The pains, according to Kadare, come from Albania's misfortune of falling under communist rule as well as the political mis-orientation of some Albanian reactionary forces. Indeed there are Albanians who attempt to maintain connections with the Islam world, Albanians who acknowledge the Ottoman heritage in Albania, and Albanians who hold the view that Albania should be a bridge between East and West. However, these people do not hinder Albania's integration into the EU.

\footnotetext{
${ }^{1}$ George Schopflin, "The Nature of Myth: Some Theoretical Aspects", in Albanian Identities: Myth and History, Stephanie Schwandner-Sievers \& Bernd Fischer (eds.), Bloomington: Indiana University Press, 2002.

2 Ismail Kadare, Identiteti Evropian i Shqiptarëve (The Albanians' European Identity). Tirana: Onufri, 2006.
} 
What holds Albania back is its bad image in the West, its grave problems such as political corruption, organized crime, etc. When Albania stops viewing the West as the Other and endeavors to become an ingroup member of the West, the West is still viewing Albania as the Other, Europe's inner uncivilized and underdeveloped Other. The ghost of the anti-Albanian priest in Kadare's The General of the Dead Army is still perceivable. As Gëzim Alpion has found out after his research of the coverage Albania received in British press during 2001-2005, “Albania's image as a 'primitive', 'uncivilized' and 'dangerous' but still fun-to-visit place, prevails even nowadays when this corner of the Balkans is no longer an isolated country" (12). ${ }^{1}$ A great number of Albanians are getting increasingly frustrated that after more than twenty years, Albania is still shut out of the European Union. It now remains one of the three places in the Balkans that have not obtained EU's candidacy. ${ }^{2}$ The expected maternal love and acknowledgement is still lacking.

In the process of turning the Western Other into Mother, the Oriental Other not only continues to exist in Kadare's works, but is highlighted even more as the Other that the Albanian nation should distance from. In other words, Kadare seems to believe that to identify with the West entails further Otherizing the East. Therefore he depicts the East, the Islam East in particular, as the incompatible Other of Christianity and dismisses everything that would remind or impress the West of Albanian nation's Muslim identity. Noting this and taking Kadare's name as an example, Qosja criticizes Kadare as anti-Islamic civilization:

In his haste to dismiss the Muslim elements, indeed Muslim identity as part of the overall identity of Albanians, Ismail Kadare has gone so far as to dismiss the names and family names of several million Albanians, which means that he is dismissive of the

\footnotetext{
${ }^{1}$ Gëzim Alpion, "Western Media and the European "Other": Images of Albania in the British Press in the New Millennium," Albanian Journal of Politics. I (1): 4-25, 2005.

${ }^{2}$ Bosnia and Kosovo are recognized by the EU as potential candidates, though EU has never recognized Kosovo as a state due to the lack of unanimity among the EU member states.
} 
civilization that created them. But not only that. In his dismissive haste Ismail Kadare has gone even further: he has dismissed his own name, Ismail, certainly refusing to understand that his name implies a civilization - that its expression is in part one of identity that it is his testimony. $(77)^{1}$

In Elegy for Kosovo (1998), Kadare created the figure of a Turkish soldier who suffered badly due to his curiosity in Christianity. The two religions fought in his heart but neither one was able to defeat the other. He was finally killed by the church for not being able to get rid of Islam. The message conveyed by this figure is clear: there is no way to stay in the middle and befriend both the Islam civilization and the Christianian civilization.

According to Kadare, Albanians should be only European and entirely European. Being European for Kadare means being the opposite of Asia, Islam in particular. Therefore he accuses Qosja's non-pragmatic view that the Albanian nation is part of both Asia and Europe. If the words "dismiss" or "negate" are not totally proper to describe Kadare's attitude toward Islam, he is certainly doing his utmost to distance the Albanian nation from Islam in order to show their entire European identity.

Sadly, the emotional rhetoric call of Mother has not brought unconditional love from Europe, neither has it helped Albanians to view themselves as part of Europe. In 2006, when Albania signed the Stablisation and Association Agreement with the EU, we saw the event reported on the front pages of Albanian newspapers like this: "Albania has one foot in the EU" (Korrieri), "Berisha signs up for European Albania" (Rilindja Demokratike), "Europe opens door to Albanians" (Standard). All these titles refer to an Albania still excluded from Europe.

This awareness of being an "outsider" is evident also in Kadares' The Albanians'

\footnotetext{
${ }^{1}$ Rexhep Qosja, "Realiteti i shpërfillur: vështrim kritik mbi pikëpamjet e Ismail Kadaresë për identitetin shqiptar" (Disregarded reality: a Critical Insight on Ismail Kadare's viewpoints on Albanian identity) Tirana: TOENA, 2006.
} 
European Identity. In contrast to the claim that Albania is totally and purely European, the "outsider" sense permeates the booklet. For example, talking about why Albania is still out of Europe, Kadare says:

Before we look from outside to find the obstacles that do not allow us or seem not to allow us to approach Europe, we should look inside ourselves. It is not hindered by any religion, and especially not by Muslimism against which the doubt is most likely to occur (49, italic emphasis mine).

What we see here is that Albania is still far from Europe, in the middle of its journey from East to West, i.e. in a state of neither Oriental nor Occidental.

Van Gennep distinguishes three major phases within the "life crisis" transition process: separation, liminality (Latin word for threshold), and incorporation. He holds that rituals serve as a means of passing through the crisis of separation from the old, liminal status and the incorporation of the next passage of life. The individual in the liminal phase is neither a member of the group he previously belonged to nor is he a member of the group that he will belong to upon the completion of the rite. $(21)^{1}$

This is the situation Albanian nation is in, a liminal status. As defined by Victor Turner, "Liminal entities are neither here nor there; they are betwixt and between the positions assigned and arrayed by law, custom, convention, and ceremonial," (95) ${ }^{2}$ the Albanian nation will remain in the status of neither Asian nor European, until the rite of passage occurs, i.e. Albania becomes officially a member of the EU. For "Other" to finally become "Mother", there is still a long way to Albania to go. While the Albanian politicians talk about their progress in steering Albania back to the maternal continent, the US and the EU officials, on the other hand, speak of foundations, beginnings, responsiblities and the hard work ahead.

\footnotetext{
1 Arnold Van Gennep, The Rites of Passage. London: Routledge and Kegan Paul, 1977.

2 Victor Turner, The Ritual Process: Structure and Anti-structure, New Jersey:Transaction Publishers, 1995. 


\section{CHAPTER 7 TRANSCENDING THE OTHERNESS}

In the previous chapters, I have focused on how the Other has been constructed and reconstructed by Kadare over the past six decades for the purpose of shaping the Albanian national identity. As has been pointed out in the first chapter, the contemporary controversy over Kadare involves two issues: his attempts to present himself as a hidden dissident during the communist era and his statement that the Albanian nation's identity is purely European. Kadare's attitude toward these two issues indicates that he has a black-or-white mentality. On the personal level, Kadare refuses to admit that many of his works were written to serve the national-communist ideology; on the collective level, he refuses to admit that there are Eastern or Asian elements in the Albanian nation's identity. As a result of his dichotomist mentality, Kadare in the real world is inclined to ignore the truth about his own history and the Albanian social reality. On the other hand, in Kadare's fictional world, we see another picture. The four Others constructed in Kadare's works demonstrate that Kadare has consistently employed Othering as an effective tool to create the paradigm for the Albanian people to separate themselves from any collectives that do not fit within the typology of the nation. It seems that Kadare is also oriented by dichotomism in writing fictions. However, a further examination of Kadare's novels shows that Kadare is more than a dichotomist mind. A great number of Kadare's descriptions tell that Kadare has an insightful vision of human conditions. There is no lack of instances which show that while a certain Otherness is politically constructed by Kadare for creating the nation's self image, it is at the same time humanistically deconstructed. 
Therefore Fatmir Alimani comments, "The writer [Kadare] and his life are usually maintained on two parallel rails of the road. $(235)^{1}$ In other words, Kadare lives by the dichotomist principle whereas he writes by another. That is why as a person in reality Kadare is criticized but as a writer of fictions he is hailed. It is based on this self-contradiction of Kadare that this dissertation views him as a fitting mind to probe in order to examine the construction of the Albanian national identity and to better understand the political nature of national identity.

National identity is perhaps the most powerful and pervasive form of collective identity. As has been affirmed by Anthony Smith, "Today national identity is the main form of collective identification. [...], it provides the dominant criterion of culture and identity, the sole principle of government and the chief focus of social and economic activity" (1991: 70). ${ }^{2}$ However, like all the other social identities, national identity cannot be constructed without the Other. In other words, national identity is inherently relational. It is in the dichotomist language and the stereotypes of the Other that the nation constructs its own self-identity. "This is why native talk about various important and unimportant Others - even if this is full of negative stereotypes and accusations - can tell us so much about the most valued aspects of one's own identity" (Theodossopoulos 177). ${ }^{3}$

National identity is in nature politically imagined and constructed. Otherness, as a result of the political rhetoric of exclusion, is created in the process of othering, through which some nations are defined as an incompatible and unworthy 'them" or out-group Other of the nation. In constructing a national identity, a collective story of

\footnotetext{
${ }^{1}$ Fatmir Alimani, Katër K: Kavabata, Kundera, Kadare, Kafka (The Four K: Kawabata, Kundera, Kadare, Kafka), Tirana: Onufri, 2004. The original words in Albanian: Shkrimtari dhe jeta vazhdojnë të mbeten zakonisht "dy shina paralele".

2 Anthony Smith, National Identity, London: Penguin, 1991.

${ }^{3}$ Dimitrios Theodossopoulos, "Degrading Others and Honoring Ourselves: Ethnic Stereotypes as Categories and as Explanations," Journal of Mediterranean Studies, 13 (2): 177-188, 2003. 
the nation in relation to the Other is fabricated by the nation's intellectual elite via political rhetoric, myths and mythistory that narrate the glorious past of the nation at the expense of some other nations being made the scapegoats for the nation's present troubles. It is in this way of othering that nationalism, as a powerful ideology for nation formation and cohesion, functions in creating, promoting and maintaining the national identify. On the other hand, the constructed national identity, in turn, becomes an effective device of nationalism for taking social and political actions.

The construction of Albanian national identity is no exception in terms of its political nature and othering process. The modern Albanian nation came into being in the course of fighting against the collapsing Ottoman Empire. Talking about the differences between the Western European nationlism and the Eastern European nationalsim, Smith points out that "Western model arose out of the Western absolutist states whereas the Eastern model emerged out of the situation of incorporated ethnic communities, whose intelligentsias sought to liberate them from the shackles of various empires" (61). ${ }^{1}$ Like the other Balkan nations that shook off the Ottoman yoke in the $19^{\text {th }}$ century, Albanian Renaissance intellectuals made enormous efforts to awaken the Albanian people's consciousness of their ethnic descent and common cultural ties. Preoccupied with the goal of forming their own national state, they invented myths to illustrate the nation's antiquity, its glorious history and other distinctive features, such as the Pelasgian origin of Albanian nation, Scanderbeg's heroic fighting against the Ottomans, etc. Meanwhile, threatened by the expansion of the neighboring nations, there was an urgent need to differentiate Albanians from the Greeks and Slavs. Thus Albanian intellectuals upheld the banner of Albanianism, i.e. the common core of being Albanians, to downplay the different religious beliefs

\footnotetext{
${ }^{1}$ Anthony D. Smith. "National Identity and the Idea of European Unity," International Affairs, Vol. 68, No. 1 (Jan., 1992), pp. 55-76.
} 
among its population and to emphasize its distinctive features from the neighbors.

During the communist era, the Albanian national identity underwent the second wave of construction. Aside from the emphasis on the glorious antiquity of the nation and the heroic resistance against Ottoman invaders, which was the central task of the Reinassance period national identity construction, new elements such as the Albanian Communist Party's role as the savior and the bright future of communism were added to the Albanian national identity, making it a syncretist combination of the Rennaissance myths and communist myths. During Hoxha's regime, nationalism and communism grew together in symbiosis, which as a result produced the so-called Albanian national-communist mythology. The main periods of Albanian national-communist mythology include Albania's ancient time which was as civilized as the Greeks, the pre-Ottoman invasion period with independent principalities and flourishing civilization, the heroic period of Skanderbeg's fighting against the Ottomans, and the partisan resistance period. As in every mythology, anti-heroes were portrayed in contrast with the heroes of glorious epochs: the Roman invaders, the Turks, the Serbs and the Greeks, the Nazi-Fascists and their Albanian collaborators (Lubonja 95). ${ }^{1}$

Kadare's works are the best example to show how literary creations have contributed to the construction and reconstruction of the Albanian national identity over the past six decades. His works cover all the above mentioned periods and provided nourishment to the national-communist mythology. He is such a superb master of using myths and historiography that his works can be viewed as the narration of history. Aware of the power of nationalism and othering, Kadare is particularly devoted to the creation of national Others in service of the formation of

\footnotetext{
${ }^{1}$ Fatos Lubonja, "Between the Glory of a Virtual World and the Misery of a Real World," pp. 95-100, in Stephanie Schwander-Sievers and Bernd Fischer, (eds.) Albanian Identities: Myth and History. Bloomington: Indiana University Press, 2002.
} 
the nation's self-identity. The four Others in his works, namely the Western Other, the Oriental Other, the Internal Other and the Neighboring Other, cover completely the anti-heroes of the Albanian national-communist mythology pointed out by Lubonja: the Western Other covers the Roman invaders and the Nazi Fascists, the Oriental Other covers the Turks, the Internal Other covers the foreign collaborators, and the Neighboring Other covers the Serbs. Additionally, Kadare also portrayed the Kanun as the most evil and harmful Internal Other that should be eliminated, Soviet Union and China as the contemporary Oriental Others that should be distanced, and the totalitarianism as an inhuman Oriental system imposed on the Albanian nation. In short, Kadare's works have a full coverage of Others and are an ideal source for better understanding the politically imagined nature of national identity and the indispensable role of Othering in national identity formation.

The four Others examined in this research provide good evidence for us to see the fluid nature of national identity and the role of political Othering in building up the national identity. The Western Other is most evident in The General of the Dead Army (1963) and Doruntine (1978). The Italian general and priest were created to highlight the Albanian people's humanistic and peace-loving spirit. The rise of Constantine from the grave in order to return Doruntine to her mother is presented as an institutionalisation of the besa, the creation of a superior institution that Albanians needed to keep themselves united against assimiliation by the Christian Church. By revealing the crimes committed by the West against the Albanian nation, their evilness, hostility, conspiracy, dishonesty, hypocrisy, decadence, etc., Kadare contributed to the shaping of the Albanian nation's self identity: a nation which fell victim to the Western monster from across the sea, a nation which heroically defended their country from the invaders, a nation that has survived numerous misfortunes 
while maintaining its core national values.

Through the Western Other, Kadare painted a typical "dehumanizing picture of the West" called Occidentalism. It is worth noting that Kadare's othering of the West is almost always done by portraying the Christian Church as the culprit, through the evil figures such as the priest in The General of Dead Army, and the bishop in Doruntine. The construction of the Western Other served the political need of the Albanian communist regime's anti-Western policy and its anti-religious policy. In a broader sense, the Western Other in Kadare's works can be viewed as a constitutive part of the whole Occidentalist repertoire constructed by the intellectuals of the former Eastern European communist countries.

The Oriental Other appears in many of Kadare's works, such as The Castle (1970), The Three-Arched Bridge (1978), The Palace of Dreams (1981), The Great Winter (1973), The Concert (1988), The Pyramid (1992), etc., which can be seen as the chronicles of Albania's political vicissitude. The major attributes of the Oriental Other constructed in these works are hegemonic, insidious and totalitarian. The Ottoman Other is constructed to reinforce the Albanian people's national consciousness, particularly their national pride for the heroic anti-Ottoman resistance under Skanderbeg and their national hate for the five-century long barbarian rule. The myth of Turkish obscurantism is used as an effective way to justify the backwardness of the Albanian economy and society. In portraying the Ottoman Other, Kadare made use of the whole Orientalist discourse to strengthen the belief that all the present trouble had its origin from the Ottoman rule. In contrast to the barbarian Ottoman Other, a pre-Ottoman Albania with flourishing civilization is constructed. The lamentation of the Albanian nation's ill fate of being grouped with the Ottomans, which led to the loss of its previous civilization and its eventual underdevelopment, played an 
effective role in mobilizing the Albanians and strengthening their desire to re-build the once-glorious Albanian state.

Employing historiography to serve the contemporary purposes, Kadare uses the Ottoman Empire to allude to the modern hegemonic powers and the totalitarianism. Apart from The Great Winter and The Concert, which directly treat the breakups of Soviet-Albanian and Sino-Albanian relations, most of Kadare's works depicting the Oriental Other are set in the historical background of the Ottoman Empire. The Castle, The Three-Arched Bridge are set in the Ottoman Empire's rising period, whereas The Palace of Dreams is set in its declining phase. However, no Albanian reader could be unaware of the analogy construed in The Castle between the Sublime Porte and the Kremlin. The apparent allusion to the USSR - USA rivalry in providing financial aid to the small in-between nations is also more than clear in The Three-Arched Bridge. The messages imbedded in The Palace of Dreams are more complicated; nevertheless, the readers cannot miss the analogy between the late 1970s Soviet Union/Yugoslavia and the $19^{\text {th }}$ century Ottoman Empire.

The Internal Other found in Kadare's works of 1960s and 1970s also constitutes an important part of the Albanian national identity construction, because without the negation and elimination of the Internal Other, the ambitious goal of building the new Albania would be at stake. The targeted Internal Others include the religious Other, the Kanun Other, the old bourgeoisie Other, etc. The religious Other was highlighted to echo the regime's anti-religious policy. It is constructed mainly through fictional figures of the local Christian clerics, such as monk Gjon in The Three-Arched Bridge, hermit Frok in The File on H., and the churchmen in The Wedding, who have either done harm to the Albanian nation or have committed crimes against Albanian people. The Kanun Other is portrayed in The Broken April as an ideological tool used by the 
exploiting class for economic profit and accused in The Wedding as the oppressor standing in the way of women's emancipation. The old bourgeoisie Other, which is presented in The Great Winter as celebrating the Soviet-Albanian break and dreaming of Albania's westernization, was guarded against for its potential collaboration with the capitalist West. In a word, the Internal Other is constructed to consolidate the communist rule and promote social progress. It is closely related to the development of the international political situation and reflects Albania's political orientation in terms of its international relations.

The Neighboring Other has been the source of pain for the Albanian nation ever since its partition in 1913. Trapped by numerous problems within Albania and lacking the international support for territorial claim over Kosovo, Hoxha's regime acted cautiously not to irritate the Yugoslavia/Serbia with the sovereignty dispute. Instead, he took time to enhance Kosovo Albanians' national consciousness and their desire for national unification. It was not until the late 1970s that Hoxha's regime saw it as the right time to address the issue of Kosovo's sovereignty. The time of the Serbian Other's appearance in Kadare's works indicates such a political change of the Albanian government.

The Serbian Other is portrayed first of all as an illegitimate occupier who grabbed Kosovo by force during the 1912-1913 Balkan Wars. In The Three-Arched Bridge (1978), The Palace of Dreams (1981), and The Broken April (1980), Kadare touched upon the Kosovo issue while emphasizing the indigenousness of the Kosovo Albanians and their recent history as the owner of Kosovo. In The File on H. (1981) and The Dark Year (1983), Kadare made the Kosovo problem an accentuated theme of the works, using the ancient Albanian epics as evidence for Albania's right to own Kosovo and lamenting the partition done to Albanian nation by the European great 
powers in 1914. When the 1981 demonstrations took place, Kadare reacted quickly by writing The Wedding Procession Turned to Ice (1986), where he vehemently denounced the atrocities committed by Serbian police against the Kosovo Albanians. In this novel, Serbia is presented as a horrible anti-Albanian criminal, both in history and reality. In the wake of the Kosovo War, Kadare published a collection of his diaries and articles in 1999 against the Serbian criminal Other. Additionally, the animosity between Albanians and Serbs is identified as irreconcilable, most evidently in The Wedding Procession Turned to Ice (1986) and Elegy for Kosovo (1998). All these efforts of presenting Serbia as an evil and irreconcilable Other aim at gaining sympathy and support from the international community, the Western world in particular. In a word, the rhetoric of the Neighboring Other was created to serve as a centripetal force for the unification of the Albanian nation.

The four Others appear somewhat in a chronicle sequence, though sometimes they are parallel to each other. The Western Other is found in Kadare's 1960s and 1970s works, the Oriental Other in his fictions published after 1970 to this date, the Internal Other in late 1960s and late 1970s, and the Neighboring Other in 1980s and 1990s. Each of the four Others reflects the political situation of a particular period in Albania as well as in the world, and each of them served a particular political purpose. They are the product of the political rhetoric of othering and the contributing factors to the construction of the Albanian national identity.

The construction of Others by Kadare shows how the nationalist rhetoric works by attributing epithets and characteristics to the Other in completely opposition to the image of the Self. As observed by Brown and Theodossopoulos, the act of Othering is "based on the selective subtraction of certain desirable properties", and in order to construct the positive Self, "the Other is deprived of some essential positive 
characteristics" (6). ${ }^{1}$ That is to say, if the nation is good and righteous then the Other is presented as evil and immoral. If the nation is civilized, then the Other is barbarian. The nationalist Othering is done under the assumption that presenting the other nation as evil automatically endows the Self with the quality of good. The four Others constructed by Kadare can be seen as four mirrors through which the positive qualities of the Albanian national Self are presented.

The political nature of Albanian national identity is more than clear when one looks at why the Western Other changes into Mother in the post-Cold War context. Kadare himself gave the answer to the question: Albania "must ally herself with her European family, in keeping with her own dignity" (Albanian Spring, 111-112). That is to say Mother is identified out of pragmatic consideration. Moreover, from Kadare's remarks, particularly from his essay The European Identity of Albanians, it is obvious the European Mother is not confined to the European continent, but extended across the Atlantic Ocean. What Kadare calls as Mother Europe is in fact a trans-Atlantic Europe in which the US plays an even bigger role than Europe. In order to convince Europe that Albania should be allowed to join the EU, Kadare takes great pains to emphasize Albania's contributions to Europe in holding back the Ottomans in the $15^{\text {th }}$ century. He even creates new myths, such as presenting the modern Turkey which is lining up in front of the EU gate as a trophy carried by the Balkan countries to Europe. Besides, in order to argue against the influential Kosovo intellectual R. Qosja's theory that Albanians as an in-between nation with a long history under the Ottoman rule and remarkable Ottoman heritage in its culture should play a positive role in linking East and West, Kadare uses factors such as language, race, geography, history, culture, etc. to claim the immutability of Albania's European essence.

\footnotetext{
${ }^{1}$ Brown, K., \& Theodossopoulos, D. "Others' others: Talking about stereotypes and constructions of otherness in southeast Europe," History \& Anthropology, 15 (1), 3-14, 2004.
} 
However, claiming the re-found but eternal European Mother entails distancing from the Eastern Other, particularly the Islamist nations. Therefore, before the Other to Mother rite of passage is completed, Albania will remain in a luminal status, a status of neither Eastern nor Western.

As a nation situated on the fault line between East and West, Albanians have learned from history how to survive on this in-between land while benefiting maximally from the competitions between East and West. As a result of constant shifting from one religion to another for pragmatic purposes, Albanians have never been fanatic in terms of their religious adherence. The pragmatic tradition of the Albanians is pointed out also in the history written by the Albanian Sciences Academy: "The practice of changing the religion for political pragmatism in fact has existed ever since the Middle Ages. Particularly, the medieval Albanian princes had made it a tradition that their religious belonging should be compatible with the Eastern or Western allied countries" (599). ${ }^{1}$ On the contrary, the flexibility to shift identity according to actual needs has become a particular feature of their culture. Skanderbeg is the best example for this feature. As explained by Kadare in his novel The Concert, "The two religions met here in an infernal clash. Neither drew back, and in the end Albania adopted both, and her hero [Skanderbeg] took two names, one Christian, the other Islamic: George and Skander" (175). The Albanian pragmatic philosophy is evident also today. Many Albanians adopted new Greek-Orthodox names in order to obtain the visas to work in Greece. Kadare's post-communist re-popularity among the Albanians also proves that most Albanians would not perceive identity change as something against their moral values. Naturally, Kadare's

\footnotetext{
${ }^{1}$ Skënder Anamali, Kristaq Prifti, Instituti i Historisë, Akademia e Shkencave e RSH (History Institute of the Albanian Sciences Academy) Historia e Popullit Shqiptar I - Ilirët Mesjeta Shqipëria nën Perandorinë Osmane gjatë shek. XVI - Vitet 20 të shek.XIX (History of the Albanian People, vol. I, Illyrians, the Middle Age, Albania under the Ottoman Empire during $14^{\text {th }}$ century -1820s). Tirana: Toena, 2002.
} 
re-popularity doesn't mean that there is no voice against him. Some insist that Kadare benefited greatly during the Albanian communist rule, thus is not a legitimate figure for the position of the leading Albanian intellectual in the post-communist era. But it is worth noting that for most of the Albanians who don't like Kadare, it is not his opportunism that they reproach. What they find as unacceptable is Kadare's attempts to rewrite his history under the communist regime. Albanian people are tolerant to identity change, because after all, identity, be it personal or national, is a means to a specific end rather than an end in itself. Metaphorically, like a chameleon changing color for defense against dangers, humans tend to identify with a social structure that appears to provide greater degrees of security and better conditions for existence. History has taught Albanians how to survive with pragmatism and flexibility.

Kadare's works reflect the changes of Albania's political situation as well as the maturation of his own political view. In 1950s-1960s, when Albania was fast becoming a modernized country, Kadare, as a young man who was confident about his country's bright future, wrote works that expressed his political enthusiasm and his pro-communist attitude. In the 1970s, Kadare started to doubt the righteousness of the communist rule. As a privileged writer, he enjoyed the freedom to go abroad and had chances to learn about the truth regarding the political conflicts within the Albanian Communist Party. As a result, he gradually grew unhappy with Hoxha's dictatorship. This change of Kadare can be seen from some subtle descriptions in his late 1970s works. For example, at the end of The Three-Arched Bridge, Kadare writes:

I should return as soon as possible and finish it, because times are black; soon night may fall, it will be too late for everything, and we may pay with our lives for writing such testimonies. This was the immured man's message. And this chronicle, like the bridge itself, may demand a sacrifice, and that sacrifice can be 
none other than myself. (184)

Here, Gjon the narrator, Kadare's alter-other, complains about the black times he was in and the lack of freedom for recording the truth, which can be interpreted as Kadare's lamentation of the sacrifices imposed on Albanians for the building of communist Albania, including his own sacrificed freedom of writing. Nevertheless, in order to survive, Kadare continued to write in support of the Albanian communist regime. Many of his works of this period served to glorify Enver Hoxha as the Albanian national hero, to justify Albania's isolation policy and to crack down the old ruling class that parasitized the Kanun.

In 1980s, the political struggle between Enver Hoxha and the Western oriented liberal forces became even more intense, which led to the incident of Hoxha's successor Mehmet Shehu's "suicide" in 1981. In his work Palace of the Dreams (1981), Kadare almost blatantly expressed his suffering under the totalitarian rule. In 1980s Kadare stopped writing in support of Communism, but he continued to write nationalist works. The difference between his pre-1980 and post-1980 nationalist works is that the pre-1980 ones aimed to establish the national Self through the Western Other and Oriental Other, with the focus on Albania's antiquity, victimhood and heroism, whereas the post-1980 ones aimed to strengthen Albanian national sentiment and to claim Albania's sovereignty over Kosovo.

According to himself, Kadare wrote in the latter half of the 1980s a few anti-communist works which were afterwards smuggled to France. It indicates that Kadare was growing increasingly aware of the imminent collapse of communism and becoming increasingly hostile to totalitarianism. From 1990s onward, the West has been de-otherized by Kadare, whereas the East continues to be viewed as the Other. At the same time, as a result of the exacerbation of the Kosovo problem and the 
growth of nationalistic sentiments, Serbia continued to be portrayed as the sworn enemy of the Albanian nation.

In 1999, the British journalist R. Carver described his trip to Albania as deeply impressed by the bunkers inherited from the communist era:

Yet even in the wilderness, in the very highest passes, perched on crags and hidden in narrow valleys, there were bunkers built by Hoxha. These and the occasional enormous Socialist Realist concrete statues of heroic partisans waving their rifles from rocky eminences gave the landscape a surreal quality, as though some eccentric billionaire had commissioned Christo and Salvador Dalí to create a satirical Communist-Paranoid theme park in this remote Balkan wilderness. (80)

Yet the numerous concrete bunkers are only part of the communist legacy; the mentality of othering should be noted as an equally remarkable part of the communist legacy. Nationalism, which has caused Nazis to create death camps, is unfortunately still popular among the Balkan peoples. Kadare has contributed significantly to the popularity of nationalism by producing acrimonious and poignant nationalist works in 1980s and 1990s. Apart from portraying himself as anti-communist and anti-totalitarian, the portrayal of the Serbian Other is Kadare's major concern in his works after 1990.

Taking a holistic view of Kadare's works, we can affirm that Kadare is an opportunistic political writer. Opportunism is defined in dictionaries as "the adaptation of policy or judgement to circumstances or opportunity, esp. regardless of principle"1 or as "the art, policy, or practice of taking advantage of opportunities or circumstances often with little regard for principles or consequences". ${ }^{2}$ Kadare was good at judging the circumstances and adapting to them for his own survival and personal gain. He knew how to make use of his close relationship with Enver Hoxha

\footnotetext{
1 The Concise Oxford Dictionary, Ninth Edition edited by Della Thompson, Oxford University Press, p. 956.

${ }^{2}$ See http://www.merriam-webster.com/dictionary/opportunism?show=0\&t=1374420589, the online Merriam Webster Dictionary.
} 
and his international fame. He was sensitive to what political themes should be treated to fit in a certain political situation and to what extent his subtle dissident expressions would be allowed. Like Gjon in The Three-Arched Bridge, who assisted the Ottomans in commiting crime even if he knew, semi-consciously, what he was doing, Kadare after the 1970s was also aware of the role he was playing, even though he was not happy about it. He was, as Malcolm has reiterated, "an employee of the Palace of Nightmares that was Enver Hoxha's Albania," while retaining in his heart "his own complex loyalties to an inner, mythic world" (24). ${ }^{1} \mathrm{He}$ is, in Robert Elsie's words, a "profoundly dissident writer," who led an "extremely conformist, even collaborationist, life" (221). ${ }^{2}$ As noted by Perter Morgan, Kadare's self-protection awarnesss might have been initiated in late 1950s when he was staying in Moscow as a student and observed from nearby the fates of Russian writers, particularly the fate of Pasternak (40). ${ }^{3}$

However, politically opportunist as he is, Kadare is undeniably a great writer. $\mathrm{He}$ masterly incorporates Greek tragedy into the modern novel, making the "synthesis of the grand tragedy and the grotesque"4 a particularly effective narrative technique. He uses a variety of literary genres and devices - allegory, satire, historical distancing, legend, history, mythology, etc. - to construct trenchant political allegories, to parallel and comment powerfully on contemporary issues. Kadare's English translator David Bellos (from French) calls Kadare a wonderful exception because "Whatever has been lost by way of wit or topical reference through the double filter of Albanian and

\footnotetext{
${ }^{1}$ Noel Malcolm. "In the Palace of Nightmares." Review of The Three-Arched Bridge, by Ismail Kadare. New York Review of Books 44.7 (6 Nov. 1997): 21-24.

${ }^{2}$ Robert Elsie, Albanian Literature: A Short History. London: Centre for Albanian Studies, 2005.

3 Peter Morgan, Ismail Kadare: The Writer and the Dictatorship 1957-1990. London: Leganda, 2010.

${ }^{4}$ This is Kadare's own opinion about the way how he writes. In answering the question "It seems to me that in your oeuvre you have tried to incorporate Greek tragedy into the modern novel." he said, "That is exact. I have tried to make a sort of synthesis of the grand tragedy and the grotesque, of which the supreme example is Don Quixote-one of the greatest works of world literature." See Ismail Kadare and Shusha Guppy. "Ismail Kadare: The Art of Fiction CLIII." Paris Review 40, no. 147 (summer 1998): 195-217.
} 
French, the strength of Kadare's imagination, insight and sarcasm, as well as his recurrent obsessions make the English versions remarkable texts in their own right". Robert Elsie has observed that "[t]here can also be no doubt that [Kadare] has contributed more than any other author to the advancement of contemporary Albanian letters, both through his works and through his candid criticism of mediocrity and politically motivated stereotyping". His insightful depiction of the mechanism of repression, of the relationship between the individual and the power structures which try to suppress him, as well as his powerful treatment of classic philosophical themes such as life and death, love and hate, war and peace, etc. make the humanistic values of his works universally valid rather than confined to the Albanian nation. Kadare's work is thus commented as "monumental in its artistic value and bears and conveys humanist and universal messages to the whole mankind".2

Kadare is a great writer also in his super ability of penetrating the inner being of people who are immensely different from himself in time, place and gender. Readers who have read for example the in-depth descriptions of the general's psychology in The General of the Dead Army, the skillful disclosure of the inner world of the Pasha and his top counselors in The Castle, Gjorg's pain and desire in The Broken April, Mark-Alem's inner struggle and suffering in The Palace of Dreams, etc. must have been impressed by Kadare's ability of using psychological narrative to delve deep into the minds of totally different worlds.

Kadare has often been compared to Franz Kafka, George Orwell, Gabriel Garcia Marquez and Ivo Andric, and at the same time he has been acclaimed for his original

\footnotetext{
${ }^{1}$ David Bellos, "Inspiration from the Bard and the Barred", Sydney Morning Herald (Australia), November 26, 1994 Saturday, p. 13.

${ }^{2}$ Cited from the report "Albania Nominates Ismail Kadare for Nobel Prize in Literature" on Dec. 23, 2008, Balkan Travelers, http://www.balkantravellers.com/en/read/article/948. 
voice, which is "at once universal and deeply rooted in his own soil". ${ }^{1}$ If Thomas Mann upon arrival on the American soil in 1938 declared that "Wherever I am, Germany is", then the same can be said for Kadare. Kadare went to Paris in 1990 for political asylum and now lives half the time in Paris half the time in Albania. As a writer whose success is "mapping a whole [Albanian] culture", Kadare continues to write about Albania while merging "its history, its passion, its folklore, its politics and its disasters". ${ }^{3}$ On the other hand, the Albania Kadare brings along wherever he goes is much more than the real Albania. "In a broader context, in an esthetic context, in which an artistic work is measured of its value, that [Albania] can be Europe, it can even be the world" (239). ${ }^{4}$ In fact, legends such as Constantine's resurrection in Doruntine, the immurement in The Three-Arched Bridge, etc. have similar versions in the mythologies of the other Balkan nations. It is in these common Balkan cultures that Kadare's literary interpretation stands out as more representative and more distinguished, as both regional and universal.

Scholars have most often compared Kadare to Kafka. A search of the key words "Kadare" and "Kafka" showed 54 results in LexisNexis Academic and 20 results in JSTOR database. Ani Kokobobo noted the reminiscence of the castle in Franz Kafka's novel of the same name to Kadare's The Palace of Dreams (540). ${ }^{5}$ Paul Hannigan felt "a strong odor of Kafka about the book [The Palace of Dreams]" and that "Kadare's genius - like Kafka's - seems to be for expanding and ramifying what seems at first a very small idea [the government's obsession with the dreams of its citizens] into a

\footnotetext{
${ }^{1}$ Ismail Kadare and Shusha Guppy. "Ismail Kadare: The Art of Fiction CLIII." Paris Review 40, no. 147 (summer 1998): 195-217.

2 Hermann Kurzke, Thomas Mann: Life As a Work of Art: A Biography, Trans. Leslie Willson, New Jersey: Princeton University Press, 2002, p 224.

${ }^{3}$ Henley Jon and Kirsty Scott, "Albanian beats literary titans to first international Booker prize", The Guardian, June 3, 2005. http://www.guardian.co.uk/uk/2005/jun/03/world.books

${ }^{4}$ Fatmir Alimani, Katër K: Kavabata, Kundera, Kadare, Kafka (The Four K: Kawabata, Kundera, Kadare, Kafka ), Tirana: Onufri, 2004.

5 Ani Kokobobo, "Bureaucracy of Dreams: Surrealist Socialism and Surrealist Awakening in Ismail Kadare's The Palace of Dreams", Slavic Review, Vol. 70, No. 3 (Fall 2011), pp. 524-544.
} 
world". ${ }^{1}$ Peter Morgan regarded The Palace of Dreams as "a political novel in the tradition of Orwell and Kafka, a modern Castle, haunted by the theme of Albanian ethnic identity in the form of ancient bardic songs". ${ }^{2}$ Colin Walters expressed his concern that "the trouble for the present-day reader of his story of Mark-Alem in the Tabir Sarrail - a trouble far outweighing there being no Soviet empire anymore - is that one has previously read the novels and stories of Franz Kafka" ${ }^{3}$

The Palace of Dreams is the most frequently used example to illustrate the influence of Kafka on Kadare. Kadare himself admitted that he read Orwell and Kafka but thought the latter was more important. ${ }^{4}$ Indeed, Kafkaesque characteristics are pervasive in The Palace of Dreams, such as the sullen atmosphere, the labyrinth-like Palace of Dreams, the strong sense of indifference and fear, the terror of endless interrogation, the existential absurdity, the desperate inner cry for freedom, etc. Mark-Alem is a typical Kafkaesque character, who has no say of his own destiny and is locked in a world of weird scenarios with no possible escape. At the very beginning of the novel, he woke up "in the uncertain light of dawn" (The Palace of Dreams 7). In front of the bookshelves, he was "both trying to find and to avoid" (8) the words Palace of Dreams. In the Palace of Dreams, he read excessively grotesque dreams and found himself and the nations sleepless. Gradually he learned about the political struggles and conspiracies. From a naïve young man, he became the director of the Palace of Dreams who inflicted terror on other people but meanwhile is himself a victim to the totalitarian terror. The novel ends with Mark-Alem cowering alone in his cart, feeling "the fear of being wrested from the grasp of the Palace of Dreams" (190).

\footnotetext{
${ }^{1}$ Paul Hannigan, review of The Palace of Dreams by Ismail Kadare, Harvard Review, No. 5 (Fall, 1993), p. 232.

2 Peter Morgan, “Ismail Kadare, Modern Homer or Albanian Dissident?" World Literature Today, 80.5 (2006): 7-11.

${ }^{3}$ Colin Walters, “'Dream' job a true nightmare; Albanian work proves Kafkaesque”, The Washington Times, September 5, 1993, Sunday, p. B6. Colin Walters holds the view that whereas a first encounter with Kafka can make a tremendous impression, writing in the similar vein inevitably would seem derivative and flat.

${ }^{4}$ Ismail Kadare and Shusha Guppy. "Ismail Kadare: The Art of Fiction CLIII." Paris Review 40, no. 147 (summer 1998): 195-217.
} 
Almost in every page there is trace of Kafka's ghost on Kadare's hand. It is in this Kafkaesque account that Kadare's anti-totalitarian masterpiece came into being under the communist regime. As has been discussed in Chapter 3, The Palace of Dreams is embedded with multilayered meanings, including what Morgan and Walters have pointed out in the above paragraph, the theme of Albanian ethnic identity and the Ottoman Empire in allusion to the Soviet Union. That is probably why Fatmir Alimani points out in The Four $K$. that what combines Kafka and Kadare together is their "great compromises with the impossible" (242). ${ }^{1}$ That is to say, while making use of the Kafka's obscure writing style and the denunciation of the Ottoman totalitarianism to allude to the Soviet Union, Kadare served the communist regime's interest in treating the Kosovo problem and at same time comforted his inner mythic Other.

Kadare's many other works have also been analyzed in light of Kafka's influence. In The Successor, for example, the characters originate from real life such as Hoxha, Shehu (the successor) or Bashkim (the successor's son) and as a consequence, "dream and reality melt together, as in Kafka, making it difficult to identify where the nightmares really begin". ${ }^{2}$ "The novel is part mystery, part thriller, part folklore, part serious historical fiction and part (a very large part) human comedy. Comedy not as in funny but in that very dark and very European tradition of Balzac and Kafka, particularly Kafka. Life as impenetrable joke". ${ }^{3}$ Our attention is also called to the "desperate and absurd atmosphere or its biting tragicomic vision, reminiscent of Kafka, woven from the shadows of Hitler and Stalin" in Kadare's latest fiction The Fall of the Stone City. ${ }^{4}$ Talking about the latest novel, Brian Morton acclaimed

\footnotetext{
${ }^{1}$ Fatmir Alimani, Katër K: Kavabata, Kundera, Kadare, Kafka (The Four K: Kawabata, Kundera, Kadare, Kafka ), Tirana: Onufri, 2004.

2 Misha Glenny "A shot in the darkness", The Times (London), January 14, 2006, Saturday.

${ }^{3}$ Helen Elliott, "Amid the madness of Albania, a murder stirs the plot", Weekend Australian, February 25, 2006 Saturday.

${ }^{4}$ Cameron Woodhead, review of The Fall of the Stone City by Ismail Kadare, The Age (Melbourne, Australia), October 6, 2012 Saturday, section Life \& Style, p. 30.
} 
Kadare as 'this generation's Kafka, bleakly comic, ethically impenetrable, plain-spoken to the point of obscurity". "While agreeing with all the analysis regarding Kadare's employment of Kafka's nightmarish plot, his impenetrable joking comedy or plain-spoken obscurity, I challenge the suitability of the comment “ethically impenetrable". Talking about Kadare's work Pesha e Kryqit (The Weight of the Cross), Robert Elsie regretted that "Nowhere does he [Kadare] make reference to the wounded soul of the nation, to the weight of the cross borne by his people during forty-six years of mute horror, or even to the much more concrete agony of many of his fellow writers and artists. He is at all moments too obsessed -- and can one blame him? -- with his own survival". ${ }^{2}$ While Kadare's obsession with his own survival is understandable, there is certainly a difference between "ethically acceptable" and "ethically impenetrable".

"What I write is different from what I say, what I say is different from what I think, what I think is different from what I ought to think and so it goes further into the deepest darkness"(9). ${ }^{3}$ This is a quote by Kafka that Fatmir Alimani used at the very beginning of the section on Kafka. What I see from the quote is how the two great minds, Kafka and Kadare, are alike. After 1990, what Kadare says in his biographic books and interview to gain personal legitimacy in the new political context is based entirely on his dichotomist mentality. Instead of admitting that he served the communist ideology while keeping a mythic inner world, Kadare tries to portray himself as a militant dissident, though he has never clearly claimed that. The statements such as "In Albania everybody knew that I was an anti-regime writer. [...] Every time I wrote a book, I had the impression that I was thrusting a dagger into the

\footnotetext{
${ }^{1}$ Brian Morton, "The Fall of the Stone City", by Ismail Kadare, trans. John Hodgson; A mysterious and masterful novel that captures a pivotal moment in Albania's history," in The Independent, December 15, 2012.

${ }^{2}$ Robert Elsie, Review of Pesha e Kryqit (The Weight of the Cross) by Ismail Kadare, World Literature Today, Spring 92, Vol. 66, Issue 2, p. 384.

${ }^{3}$ Quoted from Fatmir Alimani, The Four K. Tirana: Onufri, 2004.
} 
dictatorship'. ${ }^{1}$ were obviously aimed at Westerners, because no Albanian would buy them as true. However, when we examine Kadare's literary fictions, we will see that aside from the Others he has created for shaping the Albanian national identity, Kadare shows his complex understanding of human conditions. Taking The General of the Dead Army for example, we can see how Kadare presents the other side of the Western Other.

First, before the general's departure for Albania, the author makes him busy meeting numerous visitors who had lost their beloved during the WWII.

Every afternoon, he would hear the doorbell ring again and again as more and more visitors came pouring into the drawing-room. They were people of all sorts, from every walk of life - wives, aged parents, ex-soldiers - and they all had the same timid air, the same reserved expression on their faces. Then others began to filter in from the more distant towns and provinces. (34)

Most of the visitors were weeping women who had lost their sons or husbands in the war. Their kindness and sense of helplessness, as well as a man shouting "This mission of yours is nothing but a hoax!"(36) stand out in opposition to the propagandized evil Western Other. The Italian people are presented as miserable victims to the war and the message conveyed here is that like the people invaded by Fascists and Nazis, the people of the invading countries are also suffering post-war trauma.

Then, the general is also depicted with some good qualities. Though he is arrogant and hostile, he is not as evil and hypocritical as the priest. He is rather simple-headed and has a sense of justice. When he found out about the crimes committed by Colonel Z. against an Albanian girl and her father, he was so ashamed that he kicked off the bag of the Colonel's bones. ${ }^{2}$ In the general, we can find all the negative and positive

\footnotetext{
${ }^{1}$ Ismail Kadare and Shusha Guppy. "Ismail Kadare: The Art of Fiction CLIII." Paris Review 40, no. 147 (summer 1998): 195-217.

2 The present editions of the novel present the general's kick of Colonel Z.'s bones as accidental, however in the 
elements needed to constitute a complex figure, i.e. a figure otherized and de-otherised at the same time.

Finally, the deserter Italian soldier's diary from which lengthy paragraphs were quoted was a truly sentimental narrative. The Italian deserter who found shelter with a local miller's family expressed his desire for peaceful life, for love and for respect. He hated to be viewed as a coward, didn't care to be found and taken back home after his death, he felt jealous of the miller's dog because Christine, the miller's daughter that the deserter soldier loved, kissed the dog good bye but not him when she got married, he recalled his experience of visiting the brothel together with his fellow soldiers and in his dream he resumed the ferocity he had before and raped Christine. All these good and bad qualities of a simple Italian soldier, in contrast to those of Colonel Z., make the novel less stereotyped in the construction of the Western Other and show the author's good understanding of the complex human condition.

Furthermore, the figure of the old Albanian woman Nica, called by Tefik Çaushi as the emblem of The General of the Dead Army, ${ }^{1}$ is also a convincing example which tells the other side of the story. Nica, whose daughter was raped and husband killed by Colonel Z., appears in the novel as the antithesis of the miller, who by sheltering the deserter Italian soldier and travelling a long way to hand in to the general the Italian sodier's bones becomes the symbol of humanism, nobility and the pride of the Albanian nation. Nica bears unbearable misfortunes and develops an inexplicable hatred toward the Western invaders, which eventually becomes her heavy psychological burden. She was determined not to tell and give the bones of

1963 edition there is no ambiguity: on their way to Tirana the general was still in his shock caused by the fact Colonel Z. was killed by an old Albanian woman because of the raping and murder he did to her family. Feeling ill, he asked the driver to pull over. He then announced his intention to throw away the Colonel's bones, for he could not take such a "criminal" and a bad omen with him. The priest attempted to stop him but in vain. The bag of the Colonel's bones fell into the river.

1 Tefik Çaushi, "Nica - emblema e "Gjeneralit"” (Nica - The Emblem of the General), Universi Letrar i Kadarasë (Kadare's Literary Universe), Tirana: Dituria,1993, pp. 109-113. 
Colonel Z., despite the government's encouragement for humanitarian gestures toward the ex-invaders. The tragic experience makes her incomprehensible or earns her the call by her fellow villagers "wretched old woman". Her open hostility toward the general and her hysteric reaction when she saw the general arise for dancing are in fact in violation of the Albanian tradition of hospitality and of course broke up the happy wedding proceedings. However it is just because of the deep understanding of Nica's war trauma and the realist presentation of her weakness that her figure, in Çaushi's word, "will forever shine like the uranium kernel” (113). ${ }^{1}$

In almost all of Kadare's fictional works we can see descriptions that transcend the dichotomist othering. Another example is Kadare's treatment of Turkish cannon scientists as fallible, decent men in The Castle. Here is what Sarudja, the head of the foundery, says to counter those who were afraid of the enlargement of the cannon's mouth.

Science would mark time if we were to whimper like the old man. With or without the wars, science should press ahead. It matters little to me who uses this cannon and against who. The important thing is that the cannon should project the shell according to my calculations. As to the rest of the affair, I leave you to see to it. (33)

Sarudja devoted himself totally to the cannon research. He scorched his hair because he was standing too close to the mouth of the cannon. When the intendant-in-chief said his name would be effaced easily despite the increased power of the cannon, Sarudja replied:

What does it matter? In this world nothing is seen at once by everyone as good or bad. (63)

As a true scientist, Sarudja doesn't have the slightest sense of jealousy when he talks about his assistent. That is why his friend admires him.

\footnotetext{
${ }^{1}$ Ibid.
} 
He is sharp-witted. He has got the gist of things and sometimes even does better than me. He'll become a great inventor, for sure. (64)

You have got a golden heart, Sarudja. - said the intendant-in-chief - The poison of envy is alien to you. Be it as you say, these cannons which today seem to tear the horizon to pieces are the fruit of you labor. (64)

Against the barbarian, savage and obscurant image of the Ottoman Other he has constructed in many of his works, Kadare shows to us here an Ottoman with advanced technology and devoted scientists, which is surely one of the reasons for the Ottoman Empire to become and keep powerful.

In The Successor, a mystery account about the murder of Enver Hoxha's successor in 1981, we see at the end of the novel an empathetic Other. Instead of complaining about what the Guide had done to him, the Successor put himself in the Guide's shoes:

You try in vain to unscramble our signs. To understand the motives of one or another among us. But we, who are both guides and successors, now and forever more reunited, embrace and throttle each other, we tire ourselves out trying to tear off each other's heads, with equal anger. If I had been the Guide, I would have inflicted the same fate on him; he and I would have ended up changing places dozens of times, as many times as similar events came to recur throughout all eternity. $(205 \text {, italic emphasis mine })^{1}$

With "he" and "I" as allegory representing two competing but mutually dependent forces in a broader sense, Kadare chooses to ignore the causes or motives of the seemingly crimes, blurring the dichotomist division between legitimate vs illegitimate, good vs evil, etc., because he is aware that there are too many complicated contributing factors to the final outcome. And he claims that this is the rule throughout history.

Even in Three Elegies for Kosovo, Kadare exhibits his excellence in writing

\footnotetext{
${ }^{1}$ Ismail Kadare, The Successor. Trans. David Bellos. Edinburgh, New York, Melbourne: Canongate, 2006.
} 
novels with humanistic values. While the theme of ancient animosity between the Albanian nation and the Serb nation is accentuated throughout the mini-novel, the relationship between the Albanian minstrel and the Serb minstrel is exceptionally good. When Vladan asked Gjorg whether he could try his instrument lahuta, Gjorg stiffened for a moment.

He did not know if it was a sin or not for him to give his lahuta to a Serbian guslar. His memory told him nothing, but the sorrow in the other man's eyes removed his doubts. As if numb, he slipped the strap of his lahuta from his shoulder. Vladan's hand trembled as he took hold of the instrument.

He held it in his hands for a few moments, then his fingers timidly stretched to pluck the single string. Gjorg saw him hold his breath. He was certain that one of two things would happen - either Vladan' hand would not obey the foreign instrument, or the instrument would not obey the foreign hand. The metallic string would snap, or Vladan's fingers would freeze. A split second could bring calamity, and yet on the other hand it could also bring harmony. (50, italic emphasis mine $)^{1}$

The two minstrels can be interpreted as the intellectuals of the two nations, the writers in particular. In this sense, the minstrels' singing is tantamount to the writers' writing and the instruments they use for singing equal the writers' pens. What is essentially different is the "ink" in the pens, i.e. the mythology and history of the respective nations that are used for nationalist purpose. No wonder Gjorg stiffened, and he knew that lahuta wouldn't work in Vladan's hands. Nevertheless, Kadare does not close the door completely for the desired harmony between the two nations. With the last sentence added, a seemingly impossible thing remains possible, all depending on the ability of the one who is going to play the instrument. In this way, Kadare expresses his humanistic view rather than nationalist view with regard to the relationship between the Albanian and Serbian nations.

During the communist era, Albanians looked up to Ismail Kadare as the literary

\footnotetext{
${ }^{1}$ Ismail Kadare, Three Elegies for Kosovo. Trans., Peter Constantine, London: The Harvill Press, 2000.
} 
"prince of the nation" for spiritual nurture. Nowadays, Kadare no longer enjoys the absolute authority he had enjoyed before but nevertheless he is still an influential figure. As such, Kadare can and is expected to play a positive role for his nation. Unfortunately, from what he says, including his interviews, biographic works, essayist articles, and his debate with R. Qosja, Kadare seems to continue with his dichotomist mentality and regards Othering as a necessary device in the creation of human communities. His world remains entirely on the dichotomy he creates between "friends" and "sworn enemies". Robert Elsie obviously had no confidence in Kadare when he wrote ten years ago that "Only time will tell if Kadare can extricate himself from his personal trauma and use his eloquent voice and talent to express what still must be said'. ${ }^{1}$ Fortunately, however, Kadare as a great writer tends to overcome his limited mind as a person. His outstanding ability of presenting complex human conditions as well as employing symbolism, mythology and history to embed multilayered messages makes him a literary genius. Hopefully, what still must be said will be fully expressed at least in the literary form and Kadare as the literary prince of Albanian nation will write more works that can serve as humanistic platforms for his nation to transcend empathically the created Otherness.

\footnotetext{
${ }^{1}$ Robert Elsie, Review of Pesha e Kryqit (The Weight of the Cross) by Ismail Kadare, World Literature Today, Spring 92, Vol. 66, Issue 2, p. 384.
} 


\section{REFERENCES}

“Albania Nominates Ismail Kadare for Nobel Prize in Literature." Balkan Travelers 23 December 2008, http://www.balkantravellers.com/en/read/article/948.

"Kadare: Shqiptarët që më penguan Nobelin.” (Kadare: the Albanians who impeded my way to the Nobel Prize), December 2, 2008. http://lajme.shqiperia.com/lajme/artikull/iden/139616/titulli/Kadare-Shqiptaretqe-me-penguan-Nobelin.

"Qosja dhe Kadare sërish përballë.” (Qosja and Kadare again face to face), 1 August 2008, http://www.balkanweb.com/gazetav5/artikull.php?id=41023.

"State of Play of EU Accession Process for Western Balkans Candidate and Potential Candidate countries." http://www.europeanforum.net/uploads/news/wb_taskforce_on_eu_enlargement _background_briefing_country_overview_en.pdf.

Agolli, Dritëro. "Mbi Debatin për Identitetin Shqiptar." Intervistë (Over the debate about Albanian identity, Interview), Shqip, 16 May 2006.

Alimani, Fatmir. Katër K: Kavabata, Kundera, Kadare, Kafka (The Four K: Kawabata, Kundera, Kadare, Kafka). Tirana: Onufri, 2004.

Alpion, Gëzim. "Western Media and the European "Other": Images of Albania in the British Press in the New Millennium.” Albanian Journal of Politics I (1): 4-25, 2005.

---. Mother Teresa: Saint or Celebrity? London and New York: Routledge, 2007.

Anamali, Skënder, Kristaq Prifti, et al. Instituti i Historisë, Akademia e Shkencave e 
RSH (History Institute of the Albanian Sciences Academy) Historia e Popullit Shqiptar I - Ilirët Mesjeta Shqipëria nën Perandorinë Osmane gjatë shek. XVIVitet 20 të shek XIX (History of the Albanian People, vol. I, Illyrians, the Middle Age, Albania under the Ottoman Empire during $14^{\text {th }}$ century -1820 s). Tirana: Toena, 2002.

Anderson, Benedict. Imagined Communities: Reflections on the Origin and the Spread on Nationalism. London: Verso, 1991.

Artisien, Patrick F. R.. "A Note on Kosovo and the Future of Yugoslav-Albanian Relations: A Balkan Perspective.” Soviet Studies Vol. 36, No. 2, April 1984, pp. 267-276.

Aulneau, Joseph \& Francois Delaisi et al. Les aspirations autonomistes en Europe: Albanie, Alsace-Lorraine, Catalogne, Finlande, îles grecques, Irlande, Macédoine, Pologne, Serbo-Croatie : leçons faites à l'École des hautes études sociales. Paris: Alcan, 1913, p. 23.

Bakic-Hayden, Milica. "Nesting Orientalisms: The Case of Former Yugoslavia." Slavic Review Vol. 54, No. 4, (Winter 1995), pp. 917-931.

Baldwin, Barry. “Call me Ismail, Kadare's Capers.” Ready Steady Book for Literature, http://www.readysteadybook.com/Article.aspx?page=onkadare.

Banja, Hasan. Establishment and Prospects of Development of Socialist Industry in the People's Republic of Albania. Tirana: Naim Frashëri, 1969.

Bartholomew, James, The Welfare State We're In. London: Politico's Publishing Ltd., 2004.

Begeja, Ksanthipi. E drejta familjare e RPS të Shqipërisë (The Family in the People's Socialist Republic of Albania). Tirana: 8 Nëntori, 1984.

Beissinger, Mark. "Nationalism and the Collapse of Soviet Communism." 
Contemporary European History, vol. 18, Special Issue 03, August 2009, pp. $331-347$.

Bellos, David. "Inspiration from the Bard and the Barred." Sydney Morning Herald (Australia), November 26, 1994, p. 13.

---. "Introduction" to Ismail Kadare's Chronicle in Stone, Trans. Arshi Pipa, Ed. David Bellos. Edinburgh, New York, Melbourne: Canongate, 2007.

Beloff, Nora. Tito's Flawed Legacy: Yugoslavia \& the West Since 1939. Boulder: Westview Press, 1985.

Biberaj, Elez. Ph.D. dissertation: Albania and China: 1962-1978, a Case Study of a Bilateral Unequal Alliance, Columbia University, 1985.

Bilefsky, Dan. "In Feuds, Isolation Engulfs Families.” The New York Times July 10, 2008.

Binder, David. “Albania planning West German Ties: Move Signals an Opening to West, but Coolness to U.S. and Soviet Continues." New York Times (1923-Current file); Jul 5, 1987; ProQuest Historical Newspapers: The New York Times (1851-2009) p. 7.

---. “Albanian Exile Writer Sees Reform," New York Times December 6, 1990, p. 2.

Bjelić, Dušan \& Obrad Savić, eds. Balkan as Metaphor: Between Globalization and Fragmentation. Cambridge: The MIT Press, 2002.

Bland, William \& Ian Price. A Tangled Web: A History of Anglo-American Relations with Albania, London: The Albanian Society, 1986.

Brahimi, Razi. "Kadare ishte si 'monument kulture', e mbronin Enveri dhe Ramiz Alia," (Kadare was like a 'cultural monument' protected by Enver and Ramiz Alia) interview, Panorama, April 29, 2012.

Brown, K., \& Theodossopoulos, D. “Others' others: Talking about stereotypes and constructions 
of otherness in southeast Europe," History \& Anthropology 15 (1), 2004, pp. 3-14.

Buruma, Ian \& Avishai Margalit. Occidentalism: The West in the Eyes of Its Enemies, New York: The Penguin Press, 2004.

Byron, Janet. "Albanian Nationalism and Socialism in the Fiction of Ismail Kadare", World Literature Today, Vol. 53, No. 4 (Autumn, 1979), pp. 614-616.

Çaushi, Tefik. "Nica - emblema e 'Gjeneralit."' (Nica - The Emblem of the General), Universi Letrar i Kadarasë (Kadare's Literary Universe) Tirana: Dituria,1993, pp. 109-113.

Cela, Alba. M.A. thesis "Orientalism in Service of Contemporary National Identity Building in Albania: The literary work of Ismail Kadare.” Proquest, 2006.

Chomsky, Noam. Hegemony Or Survival: America's Quest for Global Dominance. Sydney: Allen \& Unwin, 2003.

Conquest, Robert. Reflections on a Ravaged Century. New York: W. W. Norton \& Company, 2000.

Cook, Bernard, ed. Europe since 1945: an encyclopedia. vol. 1, New York \& London: Garland Publishing, 2001.

Cox, John K. "What's behind the veil? The Ottoman fiction of Ismail Kadare." Indiana Slavic Studies vol.16 (annual), 2006.

Drew, Elizabeth. On the Edge: The Clinton Presidency. New York: Simon \& Schuster, 1994. p. 157, quoted in P. H. Liotta, Dismembering the State: The Death of Yugoslavia and Why It Matters. Lanham of Maryland: Lexington Books, 2001.

Durham, Mary Edith. High Albania: A Victorian Traveller's Balkan Odyssey. London: Edward Arnold, 1909.

Durkheim, Emile. Suicide: A Study in Sociology. Trans. Spaulding, John A., and George Simpson, New York: Free Press, 1997. 
Elliott, Helen. "Amid the madness of Albania, a murder stirs the plot." Weekend Australian, February 25, 2006.

Elsie Robert, "Evolution and Revolution in Modern Albanian Literature." World Literature Today vol. 65, issue 2, 1991: 256-263.

---. Albanian Literature: A Short History. London: Centre for Albanian Studies, 2005.

---. History of Albanian Literature. New York: Columbia University Press, 1995.

---. Review of Pesha e Kryqit (The Weight of the Cross) by Ismail Kadare, World Literature Today Spring 1992, Vol. 66, Issue 2, p. 384.

---. Review of The General of the Dead Army in World Literature Today Vol. 65, No. 4 (Autumn, 1991), pp. 746-747.

---. Review of The Successor, by Ismail Kadare, World Literature Today vol. 78, Sep-Dec 2004, Iss. 3/4, p. 149.

---. Gathering clouds: the roots of ethnic cleansing in Kosovo and Macedonia. Peja: Dukagjini Balkan Books, 2002. The Čubrilović memorandum, "The expulsion of the Albanians." is republished by Elsie online, which is accessible at http://www.elsie.de/en/books/b29.html.

Faye, Eric. Preface to Përbindëshi, in Kadare's Vepra, vol. 1, Tirana: Onufri, 2007, pp. 229-396.

Fischer, Bernd. http://www.youtube.com/watch?v=aSpV6LtN4Ds 2009 IPFW Featured Faculty.

Foreign Relations of the United States 1949, v. 5: Eastern Europe; the Soviet Union, Washington: Government Printing Office, 1976.

Frashëri, Sami. Shqipëria, ç'ka qenë, ç'është, e ç'do të bëhet (What has Albania been, what is it and what will it be)? Bukuresht: Shoqëria Dituria, 1899; 3rd ed. Tirana: Kristo Luarasi, 1924. 
Gaddis, John Lewis. The Cold War, A New History. New York: The Penguin Press, 2005.

Gellner, Ernest. Nations and Nationalism. Ithaca: Cornell University Press, 1983.

Gennep, Arnold Van, The Rites of Passage. London: Routledge and Kegan Paul, 1977.

Giannakos, S. A. "Introduction" in S. A. Giannakos ed Ethnic Conflict: Religion, Identity, and Politics. Athens, OH: Ohio University Press, 2002.

Gjeçov, Shtjefen, comp. Kanuni i Lekë Dukagjinit (The Kanun of Leke Dukagjini). trans. Leonard Fox, New York: Gjonlekaj Publishing Co., 1989.

Glenny, Misha. “A shot in the darkness.” The Times (London) January 14, 2006.

Goldsworthy, Vesna. "Invention and In(ter)vention: The Rhetoric of Balkanization." Balkan as Metaphor: Between Globalization and Fragmentation. Eds. Dušan Bjelić \& Obrad Savić. Cambridge: The MIT Press, 2002.

---. Inventing Ruritania: The Imperialism of the Imagination. New Haven and London: Yale University Press, 1998.

Gourgouris, Stathis. Does Literature Think? Literature as Theory for an Antimythical Era. Stanford: Stanford University Press, 2003.

Gregory, Gene. "Maoist Albania Desires Better Western Relations.” Merce Sun-Star Apr 26, 1971.

Hannigan, Paul. Review of The Palace of Dreams by Ismail Kadare. Harvard Review No. 5 (Fall, 1993), p. 232.

Hasluck, Margaret. The Unwritten Law in Albania. Ed. J. H. Hutton. New York: Cambridge University Press, 1954.

Henley, Jon and Kirsty Scott. "Albanian beats literary titans to first international Booker prize." The Guardian, June 3, 2005. http://www.guardian.co.uk/uk/2005/jun/03/world.books. 
Herrmann, R. K. et al. "Images in International Relations: An Experimental Test of Cognitive Schemata.” International Studies Quarterly Vol. 41, pp. 403- 433, 1997.

Horton, John. "Life, Literature and Ethical Theory: Martha Nussbaum on the Role of Literary Imagination in Ethical Thought." Literature and the Political Imagination. Ed. Horton, John and Andrea T. Baumeister, New York: Routledge, 1996.

Hoxha, Enver. Reflections on China. Vol. 2, Tirana: 8 Nentori, 1979. Online source: http://www.enverhoxha.ru/Archive_of_books/English/enver_hoxha_reflections on_china_volume_II_eng.pdf.

---. Report on the Activity of the Central Committee of the Party of Labor of Albania. Tirana: 8 Nëntori, 1977.

Hoxha, Nexhmije. "Kadare nuk po bën gjyqin tim, por gjyqin e vetes." (Kadare is not suing me but himself) interview, September 27, 2012, Shekulli (The Century) http://shekulli.com.al/web/p.php?id=4856\&kat=100.

Huntington, Samuel. "The Clash of Civilizations." Foreign Affairs 72.3 (1993): $22-49$.

---. Who Are We? The Challenges to America's National Identity. New York: Simon \& Schuster, 2004.

Iordanova, Dina. Cinema of Flames: Balkan Film, Culture and the Media. London and Berkeley: BFI \& U California P, 2001.

Jameson, Fredric. "Third World Literature in the Era of Multinational Capitalism.' Social Text 15 (1986): 65-88.

Johnson, Randal. ed. The field of Cultural Production: Essays on Art and Literature, Cambridge: Polity Press, 1993. 
Joireman, Sandra F. "Primordialism." Nationalism and Political Identity. Cornwall: MPG Books Ltd, 2003, pp. 19-35.

Jokl, Norbert. "Die Bektaschis von Naim Frashëri," Balkan-Archiv, vol. 2, 1926, pp. 226-256. Christianity and Islam under the Sultans. Trans. Hasluck, F. W. 1929.

Jullian, Philippe. The Orientalists, European Painters of Eastern Scenes. Trans. Helga and Dinah Harrison. Oxford: Phaidon, 1977.

Kabbani, Rana. Imperial Fictions: Europe's Myths of Orient. Bloomington: Indiana University Press, 1986.

Kaçuku, Bashkim. Antologjia e poezisë shqipe bashkëkohore. (Anthology of the Contemporary Albanian Poetry) Tirana: Onufri, 2008.

Kadare, Ismail \& Alain Bosquet. Dialogue avec Alain Bosquet (Dialogue with Alain Bosquet). Paris: Fayard, 1995.

Kadare, Ismail \& D. Fernandez-Récatala, Temps Barbares: De l'Albanie au Kosovo: entretiens. Paris: Archipel, 1999. Trans. into Albanian by Artan Babaramo, Alket Çani and Luan Canaj, Kohë barbare: nga Shqipëria në Kosovë: Biseda. Tirana: Onufri, 1999).

Kadare, Ismail and Shusha Guppy. "Ismail Kadare: The Art of Fiction CLIII'. Paris Review 40, no. 147 (summer 1998): 195-217.

Kadare, Ismail. "A world in the fall” (Një botë në rënie) in Literary Works (Vepra Letrare), volume 12, Tirana: Naim Frashëri in Tirana, 1981, pp. 271-294.

---. 'Ballkani: të vërteta dhe të pavërteta'. (The Balkans: Truths and Non-truths) Ballkani i Jugut: Perspektiva nga Rajoni (The South Balkans: Perspectives from the region). Ed. Dimitrios Triantaphyllou. Tirana: Onufri, 2001.

---. "Identiteti Europian i Shqiptarëve: Sprovë." (The European Identity of Albanians: Essay.) Shekulli, March 27, 2006. 
---. "Krushqit janë të ngrirë” (The Wedding Procession Turned to Ice) in Vepra 12. Tirana: Onufri, 2009.

---. "Në Kosovë, midis vëllezërve" (In Kosovo, among brothers) in Vepra letrare 12. Tirana: Naim Frashëri, pp. 295-306, 1981.

---. "The Question of Kosovo" Kosovo in the Heart of Powder Keg. Ed. Robert Elsie. New York: Columbia University Press, 1997, pp. 233-250.

---. "The Wedding Procession Turned to Ice." Kosovo in the Heart of Powder Keg. Ed. Robert Elsie. New York: Columbia University Press, 1997, pp. 105-192.

---. "Viti i Mbrapshtë” (The Dark Year.) Koha e shkrimeve (The Time of Writings). Tirana: Naim Frasheri, 1986.

---. Agamemnon's Daughter. Trans. David Bellos. New York: Arcade Publishing, 2003.

---. Albanian Spring: the Anatomy of Tyranny (Alb. Nga një dhjetor në tjetrin). London: Saqi, 1995.

---. Broken April. Trans. by multiple authors from Albanian Prilli $i$ thyer. London: Vintage Books, 2003.

---. Chronicle in Stone. Trans. Arshi Pipa, Ed. David Bellos. Edinburgh, New York, Melbourne: Canongate, 2007.

---. Dimri i vetmisë së madhe (The winter of great solitude). Kadare Vepra 5 (volume 5 of Kadare's works), Tirana: Onufri, 2008.

---. Doruntine. Trans. Jon Rothschild. New York: New Amsterdam, 1988.

---. Ftesë në Studio (Invitation to the Studio). Tirana: Naim Frashëri, 1990.

---. General of the Dead Army. Trans. Derek Coltman. London: Vintage Books, 2008.

---. Gjenerali i ushtrisë së vdekur (General of the Dead Army). Tirana: Naim Frashëri, 1963. 
---. Identiteti Evropian i Shqiptarëve (The Albanians' European Identity). Tirana: Onufri, 2006.

---. Pashallëqet e mëdha (The Great Pasha, known in French and German as The Niche of Shame). Tirana: Naim Frashëri, 1978.

---. Pesha e kryqit (The Weight of the Cross). Paris: Fayard, 1991.

---. Ra ky mort e u pamë (Death befell and we saw each other). Tirana: Onufri, 2000.

---. Shkaba (The Eagle). Tirana: Onufri, 1995.

---. Spring Flowers, Spring Frost. Trans., David Bellos. New York: Arcade Publishing, 2002.

---. The Castle (Alb. Kështjella), Trans. Pavli Qesku, Honolulu: University Press of the Pacific, 2002, reprinting of the 1974 edition.

---. The Concert. Trans. Barbara Bray. New York: Arcade Publishing, 1994.

---. The File on H. Trans. David Bellos. London: Vintage Books, 2006.

---. The Palace of Dreams. Trans. Barbara Bray. London: Vintage Books, 2008.

---. The Pyramid. Trans. David Bellos. New York: Arcade Publishing, 1996.

---. The Siege. Trans. David Bellos. Edinburgh, New York, Melbourne: Canongate, 2008

---. The Successor. Trans. David Bellos. Edinburgh, New York, Melbourne: Canongate, 2006.

---. The Three-Arched Bridge. Trans. John Hodgson. New York: Vintage International, 1997.

---. The Wedding. Trans. Ali Cungu. Tirana: Naim Frashëri, 1968.

---. Three Elegies for Kosovo. Trans. Peter Constantine. London: The Harvill Press, 2000.

Kaplan, Robert. Balkan Ghosts. New York: Vintage Books, 1993. 
Kaufmann, H. Aggression and Altruism: A Psychological Analysis. New York: Holt, Rinehart and Winston, 1970.

Kelly, George. Clinical Psychology and Personality: The selected papers of George Kelly. New York: Wiley, 1969.

Kokobobo, Ani. "Bureaucracy of Dreams: Surrealist Socialism and Surrealist Awakening in Ismail Kadare's The Palace of Dreams.” Slavic Review Vol. 70, No. 3 (Fall 2011), pp. 524-544.

Kolev, Valery \& Christina Koulouri, eds. The Balkan Wars (Teaching Modern Southeast European History - Alternative Educational Materials, Workbook 3). Thessaloniki: Center for Democracy and Reconciliation in Southeast Europe, 2009.

Kurzke, Hermann. Thomas Mann: Life As a Work of Art: A Biography. Trans. Leslie Willson. New Jersey: Princeton University Press, 2002, p 224.

Lenin, Vladimir I. Lenin's Collected Works. 4th English Edition, vol. 30. Moscow: Progress Publishers, 1965.

Lewis, Bernard. "Muslims, Christians, and Jews: The Dream of Coexistence." New York Review of Books 26 March 1992, p. 48.

Liotta, P. H. Dismembering the State: The Death of Yugoslavia and Why It Matters. Lanham of Maryland: Lexington Books, 2001.

Logoreci, Anton. The Albanians: Europe's Forgotten Survivors. Boulder: Westview Press, 1977.

Lubonja, Fatos. "Between the Glory of a Virtual World and the Misery of a Real World." Albanian Identities: Myth and History. Eds. Stephanie Schwander-Sievers and Bernd Fischer. Bloomington: Indiana University Press, 2002, pp. 91-103. 
Malcolm, Noel. "In the Palace of Nightmares'. Review of The Three-Arched Bridge by Ismail Kadare. New York Review of Books 44.7 (6 Nov. 1997): 21-24.

---. "Myths of Albanian National Identity: Some Key Elements, as Expressed in the Works of Albanian Writers in America in the Early 19th Century'. Albanian Identities: Myth and History. Eds. Stephanie Schwander-Sievers and Bernd Fischer. Bloomington: Indiana University Press, 2002.

---. Kosovo: A Short History. London: Macmillan, 1998.

Mali, Joseph. Mythistory: The Making of a Modern Historiography. Chicago: the University of Chicago Press, 2003.

Marmullaku, Ramadan. Albania and the Albanians. Trans. Margot and Bosko Milosavljevic. Hamden: Archon Books, 1975.

Marx, Karl \& Frederick Engels. "Manifesto of the Communist Party." (February 1848), Marx/Engels Selected Works, Vol. 1, Moscow: Progress Publishers, 1969. Marx, Karl. Marx and Engels on Ireland. Moscow: Progress Publishers, 1971, pp. 126-139. http://www.marxists.org/archive/marx/works/1867/12/16.htm

McNeill, William. Mythistory and Other Essays. Chicago: University of Chicago Press, 1986.

Mead, G. H.. Mind, Self and Society. Chicago: University of Chicago Press, 1934.

Misha, Piro. "Invention of a Nationalism: Myth and Amnesia." Albanian Identities: Myth and History. Ed. Stephanie Schwander-Sievers and Bernd Fischer. Bloomington: Indiana University Press, 2002.

Mohanty, Satya. "The Epistemic Status of Cultural Identity." Identities, Race, Class, Gender, and Nationality. Ed. Linda Martin Alcoff and Eduardo Mendieta. Oxford \& Berlin: Blackwell publishing, 2003, pp. 392-405.

Moisiu, Alfred. "The inter-religious tolerance in the tradition of Albanians." speech 
delivered on the Oxford forum, November 10, 2005, http://www.forumimusliman.org/english/pershtyp7.html.

Morgan, Peter. "Ismail Kadare: Modern Homer or Albanian Dissident?" World Literature Today 80.5 (2006): 7-11.

---. "Translation and Dictatorship: the Case of Ismail Kadare." The AALITRA Review: A Journal of Literary Translation, No.2 (Melbourne: Monash University, 2010), pp. 37-41.

---. Ismail Kadare: The Writer and the Dictatorship 1957-1990. London: Leganda, 2010

Morton, Brian. "The Fall of the Stone City" by Ismail Kadare, trans. John Hodgson; A mysterious and masterful novel that captures a pivotal moment in Albania's history." The Independent, December 15, 2012.

Mouffe, Chantal. The Democratic Paradox. London: Verso, 2000.

Myftaraj, Kastriot. "Kodi sekret i romanit të Ismail Kadare Pallati i ëndrrave" (The Secret Code of I. Kadare's novel The Palace of Dreams) in Gjyqi intelektual $i$ Kadaresë (The intellectual court of Kadare), Prishtina: Buzuku, 2008, pp. $238-246$

Neumann, Iver B. and Welsh, Jennifer M. "The Other in European Self-Definition: An Addendum to the Literature on International Society." Review of International Studies Vol. 17, No. 4, 1991, pp. 327- 48.

O’Donnell, James S. A Coming of Age: Albania under Enver Hoxha, New York: distributed by Columbia University Press, 1999.

Oakes, Leigh. Language and National Identity: Comparing France and Sweden. IMPACT: STUDIES IN LANGUAGE AND SOCIETY. v. 13 (series). Amsterdam: John Benjamins, 2001: 22. 
Orwell, George. Nineteen Eighty-Four. Fairfield, Iowa: 1st World Publishing, 2004.

Osterhammel, Jürgen. Colonialism: A Theoretical Overview. Trans. Shelley Frisch. Princeton: Markus Weiner Publishers, 2005.

Petkovic, Ranko. "Yugoslavia and Albania", in Yugoslav-Albanian relations. Trans. Zvonko Petrnički, Darinka Petković;. Belgrade : Review of International Affairs, 1984

Pine, Richard. "Albania's deadly tradition of blood feuds as pervasive as ever," Irish Times, Jun 26, 2009.

Prasad, Rajendra. Colonialism-Lumpenization-Revolution, Vol. 1, Cacutta-Shanghai, 1850-1914. Delhi: Ajanta Books International, 1995.

Puto, Artan. "Fryma romantike dhe nacionaliste në debatin për identitetin shqiptar." ("The romantic and nationalistic spirit in the debate on Albanian identity") Përpjekja (The Effort, weekly artistic-philosophical journal), issue 23, 2006, pp. $13-33$.

Qosja, Rexhep. "Çështja shqiptare - historia dhe politika." Pristina: Rilindja, 1994.

---. "Identiteti shqiptar dhe kultura." (Albanian identity and culture), Shqip, May 4, 2006

---. "Idetë Raciste të Ismail Kadaresë." (The Racist Ideas of Ismail Kadare.) Shqip, May 3, 2006.

---. “Kadareja, Europa dhe Jeta Jonë” (Kadare, Europe and Our Life.) Shqip, May 7, 2006

---. "Marrëdhëniet me Ismail Kadarenë: Nuk jemi ndarë për jetë a vdekje" (Relations with Ismail Kadare: we are not separate for life or death), Interview given to the Albanian newspaper Gazeta Mapo, published on Dec. 10, 2011, http://www.peshkupauje.com/2011/12/rexhep-qosja-librat-e-rames-dhe-fevziut. 
---. "Myslymanofobia e Ismail Kadaresë.” (Ismail Kadare’s Muslim-phobia), Shqip, May 5, 2006.

---. "Myslymanofobia e Ismail Kadaresë.” (Ismail Kadare’s Muslimophobia.” Shqip, May 5, 2006.

---. "Realiteti i shpërfillur: vështrim kritik mbi pikëpamjet e Ismail Kadaresë për identitetin shqiptar" (Disregarded reality: a Critical Insight into Ismail Kadare's view on Albanian identity) Tirana: TOENA, 2006.

---. "Rrëshqitje Politike dhe Intelektuale." (Political and Intellectual Folly) Shqip, May 6, 2006.

---. "The Albanian question and its solution." Kosovo - in the Heart of the Powder Keg. Trans. and Ed. Robert Elsie, 1997, pp. 207-232.

---. Death Comes to Me from Such Eyes (Vdekja më vjen prej syve të tillë), Prishtina: Rilindja, 1974.

Ramet, Sabrina. Social currents in Eastern Europe: the sources and consequences of the great transformation. Durham: Duke University Press, 1995.

Reel, Jacques and Lynn Hunt, eds. Histories: French Construction of the Past, New York: The New Press, 1995, p. 631. Quoted in Maria Todorova, ed. Balkan Identities: Nation and Memory. New York City: New York University Press, 2004, p. 2.

Ross, Jeffrey Ian, ed. Controlling State Crime. 2nd edition. New Brunswick, NJ: Transaction Publishers, 2000.

---. ed. Varieties of State Crime and Its Control. Monsey, NJ: Criminal Justice Press, 2000.

Roudometof, Victor. "Nationalism, Globalization, and Orthodoxy: The Social Origins of Ethnic Conflict in the Balkans.” Westport, CT: Greenwood Press, 2001. 
Said, Edward. "The Public Role of Writers and Intellectuals." The Public Intellectual.

Ed. Helen Small. New York: John Wiley \& Sons, 2008, pp. 19-39.

---. Orientalism. London: Pantheon Books, 1978.

Schopflin, George. "The Function of Myth and a Taxonomy of Myths", eds. Hosking, Geoffrey and George Schopflin, Myths and Nationhood. London: Hurts \& Co, 1997.

---. "The Nature of Myth: Some Theoretical Aspects." Albanian Identities: Myth and History. Eds. Stephanie Schwandner-Sievers \& Bernd Fischer. Bloomington: Indiana University Press, 2002.

Segel, Harold B. Review of Remaining Relevant after Communism: The Role of the Writer in Eastern Europe. Ed. Andrew Baruch Wachtel. Chicago: U of Chicago Press, 2006.

Selmani, Ahmet. Preface to Kamarja e Turpit, in Kadare Vepra 8 (Volume 8 of Kadare's Works), Tirana: Onufri, 2008, p. 206.

Sestanovich, Stephen. "Did the West undo the East", The National Interest, 31(Spring 1993): 26.

Sinani, Shaban. Letërsia në totalitarizëm dhe dossier $K$. (Literature under totalitarianism and the file on K.) Tirana: Naimi, 2011.

Skoug, Kenneth N. Jr., Czechoslovakia's Lost Fight for Freedom 1967-1969: An American Embassy Perspective. Westport, CT: Praeger Publishers, 1999.

Smith, Anthony. "National Identity and the Idea of European Unity." International Affairs Vol. 68, No. 1 (Jan., 1992), pp. 55-76.

---. National Identity. London: Penguin Books, 1991.

---. The Ethnic Origins of Nations. Oxford: Blackwell, 1986.

Smyth, Robin. "Laying Siege to the Palace of Dreams." London: Observer, April 7, 
1991, p. 62.

Sofos, S. "Inter-ethnic Violence and Gendered Constructions of Ethnicity in former Yugoslavia.” Social Identities 2: 1 (1996), pp. 73-92.

St. John, Edward B. Review of The General of the Dead Army, Library Journal. 8/15/2008, Vol. 133 Issue 13, p. 68.

Sulstarova, Enis. Arratisje nga lindja: Orientalizmi shqiptar nga Naimi te Kadareja (Escape from the East: Albanian Orientalism from Naim to Kadare). Tirana: Dudaj, 2006.

---. Ligjërimi Nacionalist në Shqipëri: Rilindja Kombëtare, Komunizmi Dhe Paskomunizmi (Nationalist Discourse in Albania: National Rennaisance, Communism and Post-Communism). Tirana: Afërdita, 2003.

Sundhaussen, "Europa balcanica", 626-53, quoted in Maria Todorova. ed., Balkan Identities: Nation and Memory, London: Hurst \& Co., 2004.

Tajfel, Henri, ed. Social Identity and Intergroup Relations. Cambridge, UK: Cambridge University Press, 1982.

The Albanian Woman - A Great Force of the Revolution. Tirana: 8 Nëntori, 1978.

The Concise Oxford Dictionary, Ninth Edition, Oxford University Press, 1995. Ed. Della Thompson. Beijing: Foreign Language Teaching and Research Press, 1999.

The Constitution of the People's Socialist Republic of Albania. Approved by the People's Assembly on December 28, 1976, republished by Bjoern Andersen. March 2005. http://bjoerna.dk/dokumentation/Albanian-Constitution-1976.htm

The Institute of Marxist-Leninist Studies at the Central Committee of the Party of Labor of Albania, History of the Party of Labor of Albania. $2^{\text {nd }}$ ed. Tirana: 8 Nëntori, 1982. 
Theodossopoulos, Dimitrios. "Degrading Others and Honoring Ourselves: Ethnic Stereotypes as Categories and as Explanations." Journal of Mediterranean Studies 13 (2): 177-188, 2003.

Todorova, Maria. ed., Balkan Identities: Nation and Memory. London: Hurst \& Co., 2004.

---. Imagining the Balkans. New York: Oxford University Press, 1997.

Tucović, Dimitrije. Serbia and Albania: One Contribution to the Criticism of the Subjugation Policy of the Serbian Bourgeois (Srbija i Arbanija jedan prilog kritici zavojevačke politike srpske buržoazije). Belgrade: Radnička štampa, 1914. Reprint in 1974.

Turner, Victor. The Ritual Process: Structure and Anti-structure, New Jersey: Transaction Publishers, 1995.

United States Department of State / Foreign relations of the United States, 1946. Eastern Europe, the Soviet Union (1946). Albania, page 26.

US Congressional Record, 79 Congress, $2^{\text {nd }}$ session, 1946, part 8, p. 10336.

Vickers, Miranda \& James Pettifer. Albania: From Anarchy to Balkan Identity. New York: NYU Press, 1997.

Vickers, Miranda. Between Serb and Albanian: A History of Kosovo. New York: Columbia Univ. Press, 1998.

---. The Albanians: A Modern History. London \& New York: IB Tauris \& Co 1999.

Walters, Colin. “'Dream' job a true nightmare; Albanian work proves Kafkaesque.” The Washington Times September 5, 1993, Sunday, p. B6.

Weitzman, Erica. “Specters of Narrative: Ismail Kadare's The General of the Dead Army." Journal of Narrative Theory 41.2 (Summer 2011): 282-309.

Wendt, Alexander. "Anarchy is what states make of it: the social construction of 
power politics." International Organization 46 (2), 1992, pp. 391- 425.

---. "Collective Identity Formation and the International State." American Political Science Review 88, 1994, pp. 384-96.

---. Social Theory of International Politics. Cambridge: Cambridge University Press, 1999.

White, Jeffrey. "Peacemaker breaks the ancient grip of Albania's blood feuds." Christian Science Monitor 6/24/2008, Vol. 100, Issue 147.

Wolff, Larry. Inventing Eastern Europe: The Map of Civilization on the Mind of the Enlightenment. Stanford: Stanford University Press, 1994.

Woodhead, Cameron. Review of The Fall of the Stone City by Ismail Kadare. The Age (Melbourne, Australia), October 6, 2012, section Life \& Style.

Zëri i Popullit (Voice of the People). April 8, 1981. 


\section{CURRICULUM VITAE}

\section{EDUCATION}

- 2006 - 2013

Ph. D., Humanities, University of Louisville, Kentucky, USA, (expected August 2013)

- $2000-2003$

M. A., Albanian Language and Literature, Beijing Foreign Studies University, China

- 1985 - 1989

B. A., Albanian Language and Literature, Prishtina University, Kosovo

- 1984 - 1986

Associate Degree, English major, Beijing Broadcasting Institute (Communication University of China)

\section{WORK EXPERIENCE}

- 1990 - 1996

Assistant Professor of Albanian Language and Literature, Beijing Foreign Studies University

- $1996-2003$

Lecturer of Albanian Language and Literature, Beijing Foreign Studies University

- $2003-2008$

Associate Professor of Albanian Language and Literature, Beijing Foreign Studies University

- 2008 - present

Professor of Albanian Language and Literature, Beijing Foreign Studies University 


\section{PUBLICATIONS}

\section{BOOKS}

- New Albanian Course Book. (I), Beijing: Foreign Language Teaching and Research Press, 2003.

- New Albanian Course Book. (II), Beijing: Foreign Language Teaching and Research Press, 2005.

- A Practical Albanian Grammar. Beijing: Foreign Language Teaching and Research Press, 2010.

- Albanian-Chinese Interpretation Coursebook, Beijing: Foreign Language Teaching and Research Press, forthcoming.

\section{ARTICLES}

- “Kosovo' s History, Present Situation and Future”, International Forum, 6 (2006): 67-71.

- The Personality Structure of the Protagonist in Broken April, The European Language and Culture, vol. 3. September, 2007, pp. 140-151.

- "An analysis of the EU Perspective of the West Balkans" International Forum, 6 (2007): 29-34.

- “An Interpretation of the US Policy toward Kosovo” , Contemporary International Relations, 4 (2008): 50-52.

- "Did the US media reflect the reality of the Kosovo War in an Objective Manner”, Intercultural Communication Studies, Vol. XVII: $1,2008$.

- “The Kosovo Problem in Kadare” s Works” , The European Language and Culture, vol. 6, Feb. 2011

- “Roli i korpusit shqip në punën kërkimore dhe mësimdhënëse të gjuhës shqipe në Kinë" (The Role of Albanian Corpus in the Research and Teaching of Albanian Language in China), Gjuha Jone (Our Language, Journal of the Albanian Academy of Sciences), 1-4 (2007), May 2011, pp. $147-158$

- "Change the Outgroup 0ther into the Ingroup Partner: On the 
Albanian-Serb Relations, ” The Western Balkans Policy Review, Iss. 2, Vol. 2, 2012, pp. 60-75.

\section{ONGOING RESEARCH PROJECTS}

- Albanian - Chinese Dictionary, chief editor

- The Kosovo Studies ( “The Evolution of Albanian' s Policy toward Kosovo" " "Serbia-Kosovo Relations and the EU Policy”, "Kosovo Albanians' Identity” )

- Advanced Reading in Albanian (textbook), editor 